\title{
Molecular dosimetry studies of smoking - induced carcinogenesis in target and surrogate tissues of humans
}

Citation for published version (APA):

Nia, A. B. (2001). Molecular dosimetry studies of smoking - induced carcinogenesis in target and surrogate tissues of humans. [Doctoral Thesis, Maastricht University]. Universitaire Pers Maastricht. https://doi.org/10.26481/dis.20010627an

Document status and date:

Published: 01/01/2001

DOI:

10.26481/dis.20010627an

Document Version:

Publisher's PDF, also known as Version of record

Please check the document version of this publication:

- A submitted manuscript is the version of the article upon submission and before peer-review. There can be important differences between the submitted version and the official published version of record.

People interested in the research are advised to contact the author for the final version of the publication, or visit the DOI to the publisher's website.

- The final author version and the galley proof are versions of the publication after peer review.

- The final published version features the final layout of the paper including the volume, issue and page numbers.

Link to publication

\footnotetext{
General rights rights.

- You may freely distribute the URL identifying the publication in the public portal. please follow below link for the End User Agreement:

www.umlib.nl/taverne-license

Take down policy

If you believe that this document breaches copyright please contact us at:

repository@maastrichtuniversity.nl

providing details and we will investigate your claim.
}

Copyright and moral rights for the publications made accessible in the public portal are retained by the authors and/or other copyright owners and it is a condition of accessing publications that users recognise and abide by the legal requirements associated with these

- Users may download and print one copy of any publication from the public portal for the purpose of private study or research.

- You may not further distribute the material or use it for any profit-making activity or commercial gain

If the publication is distributed under the terms of Article $25 \mathrm{fa}$ of the Dutch Copyright Act, indicated by the "Taverne" license above, 
MOLECULAR DOSIMETRY STUDIES OF SMOKING-INDUCED CARCINOGENESIS IN TARGET AND SURROGATE TISSUES OF HUMANS 
(c) Besarati Nia, Ahmad Maastricht, The Netherlands

ISBN 9052783004

Cover Designer : H.G.M. Gardeneers

Cover Photo of the Lung: Courtesy of the Department of Anatomy and Embryology, Maastricht University, photographed by Paul van Dijk

Printer : Datawyse Boekproducties Maastricht 


\section{MOLECULAR DOSIMETRY STUDIES OF SMOKING-INDUCED CARCINOGENESIS IN TARGET AND SURROGATE TISSUES OF HUMANS}

\section{PROEFSCHRIFT}

ter verkrijging van de graad van doctor aan de Universiteit Maastricht,

op gezag van de Rector Magnificus, Prof. Dr. A.C. Nieuwenhuijzen Kruseman, volgens het besluit van het College van Decanen, in het openbaar te verdedigen op woensdag 27 juni 2001 om 14.00 uur

door

Ahmad Besarati Nia

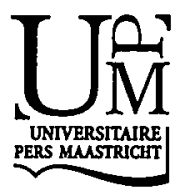




\section{Promotor:}

Prof. Dr. J.C.S. Kleinjans

Prof. Dr. F.J. Van Schooten

\section{Beoordelingscommissie:}

Prof. Dr. E.F.M. Wouters (voorzitter)

Prof. Dr. A. Bast

Prof. Dr. P.J. Van Bladeren (TNO Zeist)

Prof. Dr. P. Lambin

Prof. Dr. P.H.M. Lohman (Universiteit Leiden) 


\section{CONTENTS}

Acknowledgement

vii

Abbreviations

viii

Chapter 1 General introduction 1

1.1 Historical background 4

1.2 Tobacco smoking and cancer 4

1.3 Principal chemical constituents of tobacco smoke 5

1.4 Environmental tobacco smoke 5

1.5 Tobacco smoke carcinogenicity 6

1.6 DNA adduct-inducing agents in tobacco smoke 6

1.6.1 Polycyclic aromatic hydrocarbons 6

1.6.1.1 Biotransformation of polycyclic aromatic hydrocarbons $\quad 8$

1.6.1.2 Epidemiological and biological data on polycyclic aromatic hydrocarbons $\quad 9$

$\begin{array}{ll}\text { 1.6.2 Aromatic amines } & 15\end{array}$

1.6.2.1 Biotransformation of aromatic amines $\quad 15$

1.6.2.2 Epidemiological and biological data on aromatic amines 16

$\begin{array}{lll}1.6 .3 & \text { Reactive oxygen species } & 18\end{array}$

1.6.3.1 Biotransformation of reactive oxygen species 18

1.6.3.2 Epidemiological and biological data on reactive oxygen $\quad 19$

1.7 Induced sputum for studying tobacco smoke carcinogenicity 21

$\begin{array}{lll}1.8 & \text { Scope of the thesis } & 22\end{array}$

Chapter 2 Applicability of induced sputum for molecular dosimetry of exposure to inhalatory carcinogens: ${ }^{32} \mathrm{P}$-postlabeling of lipophilic-DNA adducts in smokers and non-smokers

Chapter 3 Comparison between smoking-related DNA adduct analysis in induced sputum and peripheral blood lymphocytes

Chapter 4 Immunoperoxidase detection of 4-aminobiphenyl- and polycyclic aromatic hydrocarbon-DNA adducts in induced sputum of smokers and non-smokers

Chapter 5 Assessment of exposure to environmental tobacco smoke in pubs

Chapter 6 A multi-biomarker approach to study the effects of smoking on oxidative DNA damage and repair and antioxidative defense mechanisms 
Chapter 7 Immunoperoxidase detection of polycyclic aromatic hydrocarbon-DNA adducts in mouth floor and buccal mucosa cells of smokers and non-smokers

Chapter 8 Effects of oral administration of $\mathrm{N}$-acetyl-L-cysteine: a multi-biomarker study in smokers

Chapter 9

Summary and conclusion

Samenvatting 


\section{ACKNOWLEDGEMENT}

My thanks to all individuals including colleagues, friends and family who directly or indirectly helped me shape the herein-presented studies. More specifically, I am grateful to all staff members of my own department and department of Anatomy and Embryology, Maastricht University, as well as of Lung Function Laboratory, Academic Hospital thanks to my co-promotor and promotor whom I immensely respect for their wisdom, gentle caring and having faith in me. It has been a wonderful four-year Maastricht (azM), for their incredible help and support. Special for me and you have been all great. Thanks so very much.

Hamid 


\section{ABBREVIATIONS}

\begin{tabular}{|c|c|}
\hline 4-ABP & 4-aminobiphenyl \\
\hline $4^{\prime}-\mathrm{F}-\mathrm{ABP}$ & 4'-fluoro-4-aminobiphenyl \\
\hline 8-oxo-Gua & 8-oxo-7,8-dihydroguanine \\
\hline $\mathrm{ABAP}$ & 2,2'-azobis-2-amidinopropane \\
\hline \multicolumn{2}{|c|}{ (+)-anti-BPDE (+)-anti-7R,8S-dihydroxy-9S,10R-epoxy-7,8,9,10-tetrahydro-benzo[a]pyrene } \\
\hline AP sites & apurine and apyrimidine sites (abasic sites) \\
\hline $\mathrm{B}[\mathrm{a}] \mathrm{A}$ & benzo[a] anthracene \\
\hline $\mathrm{B}[\mathrm{b}] \mathrm{F}$ & benzo[b]fluoranthene \\
\hline $\mathrm{B}[\mathrm{k}] \mathrm{F}$ & benzo[k]fluoranthene \\
\hline BAL & bronchoalveolar lavage \\
\hline BAM & bronchoalveolar macrophages \\
\hline BER & base excision repair \\
\hline BMI & body mass index \\
\hline $\mathrm{B}[\mathrm{a}] \mathrm{P}$ & benzo[a]pyrene \\
\hline CI & confidence interval \\
\hline $\mathrm{CV}$ & coefficient of variation \\
\hline CYP & cytochrome P-450 \\
\hline $\mathrm{DAB}$ & 3, 3' -diaminobenzidine \\
\hline $\mathrm{dG}$ & 2'-deoxyguanosine \\
\hline DMSO & dimethylsulfoxide \\
\hline DRZ & diagonal radioactive zone \\
\hline $\mathrm{EH}$ & epoxide hydolases \\
\hline ELISA & enzyme-linked immunosorbent assay \\
\hline EPA & Environmental Protection Agency \\
\hline ETS & environmental tobacco smoke \\
\hline FapyGua & 2,6-diamino-4-hydroxy-5-formamidopyrimidine \\
\hline FISH & fluorescence in situ hybridization \\
\hline GP & glutathione peroxidase \\
\hline GSH & glutathione \\
\hline GSTs & glutathione $S$-transferases \\
\hline $\mathrm{Hb}$ & hemoglobin \\
\hline $\mathrm{H}_{2} \mathrm{O}_{2}$ & hydrogen peroxide \\
\hline$h O G G 1$ & human 7,8-dihydro-8-oxo-2' -deoxyguanosine-glycosylase/apurinic lyase \\
\hline Ile & isoleucine \\
\hline IARC & International Agency for Research on Cancer \\
\hline IS & induced sputum \\
\hline HPLC-ECD & high performance liquid chromatography-electrochemical detection \\
\hline MS smoke & mainstream smoke \\
\hline MFC & mouth floor cells \\
\hline $\mathrm{NAC}$ & $N$-acetyl-L-cysteine \\
\hline NER & nucleotide excision repair \\
\hline
\end{tabular}


NICI-GC-MS capillary gas-chromatography and negative-ion chemical ionization massspectrometry

NP1 nuclease P1

NSCLC non-small cell lung cancer

$\mathrm{O}_{2}^{\circ} \quad$ superoxide anion

${ }^{+} \mathrm{O}_{2} \quad$ singlet oxygen

$\mathrm{O}_{3} \quad$ ozone

$\mathrm{OH}^{\circ} \quad$ hydroxyl

PAH polycyclic aromatic hydrocarbons

PBL peripheral blood lymphocytes

PBS phosphate buffered saline

PCR polymerase chain reaction

PEI polyethyleneimine

RIA radioimmunoassay

$\mathrm{RO}^{\circ} \quad$ alkoxyl

$\mathrm{RO}_{2}^{\circ} \quad$ peroxyl

ROS reactive oxygen species

SD standard deviation

SEM standard error of the mean

SOD superoxide dismutase

SPC soft palate cells

SS smoke sidestream smoke

TEAC trolox equivalent antioxidant capacity

UDS unscheduled DNA synthesis

UGT uridine-5'-diphosphate-glucuronosyl-transferases

Val valine

WBC white blood cells 
GENERAL INTRODUCTION 


\section{CHAPTER 1}

Biomonitoring of tobacco smoke carcinogenicity 

Biomonitoring of tobacco smoke carcinogenicity by dosimetry of DNA adducts and genotyping and phenotyping of biotransformational enzymes: a review on polycyclic aromatic hydrocarbons, aromatic amines and reactive oxygen species

A. Besarati Nia, J.C.S. Kleinjans and F.J. Van Schooten*

Department of Health Risk Analysis and Toxicology, Maastricht University, Maastricht, The Netherlands

\begin{abstract}
In this review article, we summarize the data on tobacco smoke carcinogenicity in relation to DNA adduct dosimetry and genotyping and phenotyping of biotransformational enzymes. Three major classes of carcinogens and/or mutagens, polycyclic aromatic hydrocarbons, aromatic amines and reactive oxygen species, all present in substantial quantities in tobacco smoke, are discussed. The historical backgrounds and overviews on metabolic pathways are given. The epidemiological and biological data in particular on dosimetry of the representative DNA adducts and genotyping and phenotyping of the respective activating and detoxifying enzymes are presented. The salient findings are highlighted, the uncertainties are underlined and finally, the recommendations for future research are made.
\end{abstract}

Based on the manuscript submitted for publication in: "Cancer Epidem Biomarkers Prev" 


\section{Chapter One}

\section{Biomonitoring of tobacco smoke carcinogenicity}

\subsection{Historical Background}

Historically, tobacco was offered to Columbus upon his landing on San Salvador in the Bahamas on October 12,1492 by the House of Arawaks. Subsequently, the seafaring European merchants brought seeds of tobacco plants to Spain and Portugal and promoted the American Indians' custom of smoking. In 1585, Jean Nicot, the French ambassador to Portugal, introduced tobacco at the Royal Court of Paris and in his honor, the tobacco plant was named 'Nicotiana'. Tobacco was used first in England in 1565, followed by Italy, Germany, Scandinavia, and Russia through to the year 1600 (1).

Initially, tobacco was chewed or smoked in pipes but soon cigarettes and cigars became popular. At the beginning, cigarettes were hand-made by stuffing tobacco into a hollow reed or cane or by rolling crushed tobacco leaves in a cornhusk or in leaves of other vegetables as a wrapper. The first machine-made cigarettes were manufactured in Cuba in 1853, in London in 1856 and in North America in 1860 (2).

Tobacco consumption was modest in the United States, the United Kingdom, continental Europe and Japan until World War I. In 1920, the annual consumption of cigarettes per capita [over the age of 15 years] in westem countries ranged in number from 400 to 800 . It then increased drastically up to 4400 until the mid-1960s (3). Following the report of the Royal College of Physicians of London in 1962, and that of the Surgeon General of the United States Public Health Service in 1964 on the health hazards of smoking, cigarette consumption declined significantly in developed countries (4). In the United Kingdom, the annual consumption of cigarettes per adult male dropped from 4030 in 1960 to 1982 in 1993 [50.8\% reduction] (5). Likewise, in the United States the yearly cigarette consumption per adult male decreased from 4345 in 1963 to 2493 in 1994 [ $42.6 \%$ reduction]. In $1965,51.9 \%$ and $33.9 \%$ of all adult American men and women, respectively, were cigarette smokers. In 1993, the respective numbers were $27.7 \%$ and $22.5 \%(6,7)$. Conversely, in developing countries there has been a substantial rise in annual per capita cigarette consumption between 1970 and 1990 [e.g., 260\% increase in China]. Worldwide, there has also been a shift in the age group of current smokers towards younger ages (8). Recent surveys show an appreciable increase in smoking prevalence in youth e.g., in the United States from $27.5 \%$ in 1991 to $36.4 \%$ in 1997 (9).

\subsection{Tobacco Smoking and Cancer}

Several decades of epidemiological research have identified tobacco smoking as the main cause of preventable mortality in developed countries $(10,11)$. In the United States, approximately one fifth of the deaths and one third of all cancers are attributable to smoking 
(12). Data from the mid-1980s confirm that among smokers aged 35-69, the death rate is three times higher than that in non-smokers, and that there is at least a two-fold excess mortality from all causes in old age (11). It is estimated that at least $50 \%$ of regular smokers who begin smoking during adolescence will eventually be killed by tobacco (11). Global cancer statistics show that there is a prevailing link between tobacco smoking and a variety of human cancers including cancers of the aerodigestive tract, lower respiratory tract, digestive and gastrointestinal system, renal and urinary tract, and colorectal system $(13,14)$. There are one billion smokers throughout the world, one third of whom live in China, where a major smokeassociated cancer epidemic is predicted (15). Although the argument for further tobacco control and improved smoking cessation strategies is powerful, the facts and figures imply that the utopian goal of a smoke-free society is far from distant. Instead, an understanding of smoke-induced carcinogenesis can lead to new strategies for decreasing risk, for identifying highly susceptible individuals and for developing innovative techniques for early detection.

\subsection{Principal Chemical Constituents of Tobacco Smoke}

Tobacco combustion results in the formation of mainstream (MS) smoke and sidestream (SS) smoke (16). MS smoke is generated during puff drawing in the burning cone and hot zone of a tobacco product and travels through the tobacco column outward the mouthpiece. SS smoke is formed between puffing and is emitted from the smoldering coal of the tobacco product into the ambient air (17). Both MS smoke and SS smoke are composed of (I) vapor phase containing volatile agents such as benzene, vinyl chloride, acrolein, etc., and (II) particulate phase [tar] containing semi-volatile and non-volatile agents such as alkaloids e.g., cotinine and its derivatives, aromatic amines, polycyclic aromatic hydrocarbons (PAH), etc. [Tab. 1] $(18,19)$.

Since SS smoke is generated at lower burning temperature, its chemical compositions in both vapor and particulate phases differ from those of MS smoke (20). The ratios of the selected tobacco smoke constituents in MS smoke to those in SS smoke from the non-filtered cigarettes are listed in Table 1.

\subsection{Environmental Tobacco Smoke}

Environmental tobacco smoke (ETS) originates from the smoldering end of the tobacco product in between puffs and from the smoker's exhaled smoke. Other contributors to ETS include minor amounts of smoke that escape during the puff drawing from the burning cone, and some vapor phase agents that diffuse through the cigarette paper into the environment (21). This mixture is released into the environment and subsequently, diluted by the surrounding air. It may then aggregate with pollutants already present in the environment and change character. Physicochemically, the composition of this complex mixture may considerably differ from that of MS smoke (20). Nonetheless, most toxic or carcinogenic components of the MS smoke are also present in ETS, but in different concentrations $(20,22)$. 


\subsection{Tobacco Smoke Carcinogenicity}

Of the 44 chemical agents classified as 'Group I Carcinogens' by the International Agency for Research on Cancer (IRAC) (23), nine including benzene, cadmium, arsenic, nickel, chromium, 2-naphthylamine, vinyl chloride, 4-aminobiphenyl (4-ABP) and beryllium are present in tobacco smoke (24). Based on their mode of actions, these compounds are divided into two distinct types, DNA-reactive [genotoxic] and epigenetic (25). Carcinogens of the DNA-reactive type possess specific structures that yield electrophilic reactants either spontaneously or after bioactivation. Thus, they can form covalently bound DNA adducts which in turn, may give rise to genetic alterations via e.g., oncogene activation and tumor suppressor gene inactivation (26-29). In addition, these compounds can have other cellular and tissue epigenetic effects e.g., cell proliferation and growth promotion $(25,29)$. Carcinogens of the epigenetic type, in contrast, do not generate reactive electrophiles and therefore, are not likely to react with DNA (30). Instead, they display cellular effects such as neoplasm growth promotion, cytotoxicity, inhibition of tissue growth regulation, peroxisome proliferation, endocrine modification, immunosuppression and/or sustained tissue ischemia that can promote neoplasia (30). Examples of the carcinogens of the DNA-reactive and epigenetic types are 4-ABP and nickel, respectively.

Todate, tobacco smoke carcinogenicity is extensively studied by dosimetry of DNA adducts. Conceptually, DNA adducts are defined as biologically effective dose markers of exposure to carcinogens. This is that they not only reflect a prior exposure to carcinogens but they also imply a tangible risk for cancer (27). The latter should be interpreted quite cautiously because DNA adduct formation is only one step in the multi-stage process of carcinogenesis and many other influential factors e.g., cellular proliferation, are also involved in this process (27). Therefore, it is premature to rely solely on dosimetry of DNA adducts for cancer risk estimation. More realistically, DNA adduct dosimetry can be used as a means to identify those agents, which are involved in the initiation of carcinogenesis $(27,31)$.

\subsection{DNA Adduct-inducing Agents in Tobacco Smoke}

Several classes of chemicals present in tobacco smoke can induce DNA adducts. Of these, $\mathrm{PAH}$, aromatic amines and reactive oxygen species (ROS) are discussed in the following sections.

\subsubsection{Polycyclic Aromatic Hydrocarbons}

PAH are formed as a product of tobacco combustion, and found in considerable quantities in its particulate phase (32). PAH are also emitted into the environment as a result of incomplete pyrolysis of organic materials e.g., fossil fuels. Established environmental sources of PAH are 
Table 1. Emissions of some major constituents of tobacco smoke in fresh, undiluted mainstream smoke (MS) and diluted sidestream smoke (SS) from non-filtered cigarettes, adapted from ref. (17).

\begin{tabular}{|c|c|c|}
\hline & Emissions in MS & SS/MS Ratio \\
\hline \multicolumn{3}{|l|}{ Vapor Phase } \\
\hline Carbon monoxide & $10-23 \mathrm{~ms}$ & $2.5-4.7$ \\
\hline Carbon dioxide & $20-60 \mathrm{~ms}$ & $8-11$ \\
\hline Carbon sulfide & $18-42_{\text {UR }}$ & $0.03-0.13$ \\
\hline Benzene & $12-48$ up & 10 \\
\hline Toluene & 160 UR & 6.8 \\
\hline Formaldehyde & $70-100$ gh & $0.1-\sim 50$ \\
\hline Acrolein & $60-100$ us & $8-15$ \\
\hline Acetone & $100-250 \mathrm{ug}$ & $2-5$ \\
\hline Pyridine & $16-40_{\mathrm{vg}}$ & $7-20$ \\
\hline 3-Vinylpyridine & $15-30$ us & $20-40$ \\
\hline Hydrogen cyanide & $400-500$ UR & $0.1-0.25$ \\
\hline Hydrazine & $32 n$ & 3.0 \\
\hline Ammonia & $50-150_{\mathrm{yg}}$ & $40-170$ \\
\hline Methylamine & $17.5-28.7_{\mathrm{HR}}$ & $4.2-6.4$ \\
\hline Dimethylamine & $7.8-10 \mathrm{yr}$ & $3.7-5.1$ \\
\hline Nitrogen oxides & $100-600$ & $4-10$ \\
\hline $\mathrm{N}$-Nitrosodimethylamine & $10-40 u \mathrm{~g}$ & $20-100$ \\
\hline$N$-Nitrosopyrrolidine & $6-30 n g$ & $6-30$ \\
\hline Formic acid & $210-478$ us & $1.4-1.6$ \\
\hline Acetic acid & $330-810$ & $1.9-3.9$ \\
\hline \multicolumn{3}{|l|}{ Particulate Phase } \\
\hline Particulate matter & $15-40 \mathrm{mg}$ & $1.3-1.9$ \\
\hline \begin{tabular}{|l} 
Nicotine \\
\end{tabular} & $1.7-3.3 \mathrm{mg}$ & $1.8-3.3$ \\
\hline Anatabine & $2.4-20.1$ & $0.1-0.5$ \\
\hline Phenol & $60-140_{48}$ & $1.6-3.0$ \\
\hline \begin{tabular}{|l|} 
Catechol \\
\end{tabular} & $100-360$ uR & $0.6-0.9$ \\
\hline Hydroquinone & $110-300 \mathrm{mk}$ & $0.7-0.9$ \\
\hline Aniline & $360 \mathrm{~ns}$ & 30 \\
\hline Ortho-Toluidine & $160_{\mathrm{ng}}$ & 19 \\
\hline 2-Naphthylamine & $1.7 \mathrm{ng}$ & 30 \\
\hline 4-Aminobiphenyl & $4.6 \mathrm{ng}$ & 31 \\
\hline Benzo[alanthracene & $20-70_{n g}$ & $2.2-4.0$ \\
\hline \begin{tabular}{|l} 
Benzolalpyrene \\
\end{tabular} & $20-40 \mathrm{ng}$ & $2.5-3.5$ \\
\hline \begin{tabular}{|l} 
Cholesterol \\
\end{tabular} & 14.2 us & 0.9 \\
\hline$\gamma$-Butyrolactone & $10-22$ us & $3.6-5.0$ \\
\hline Quinoline & $0.5-2 \mu R$ & $8-11$ \\
\hline Herman & $1.7-3.1_{\text {บg }}$ & $0.7-1.9$ \\
\hline$N^{\prime}$-Nitrosonornicotine & $200-3000 \mathrm{nz}$ & $0.5-3.0$ \\
\hline 4-(Methylnitrosamino)-1-(3-pyridyl)-1-butanone & $100-1000 n g$ & $1-4$ \\
\hline$N$-Nitrosodiethanolamine & $20-70 \mathrm{ng}$ & 1.2 \\
\hline Cadmium & $100_{\mathrm{ng}}$ & $3.6-7.2$ \\
\hline \begin{tabular}{|l} 
Nickel \\
\end{tabular} & $20-80 \mathrm{ng}$ & $0.2-30$ \\
\hline Zinc & $60 \mathrm{ng}$ & $0.2-6.7$ \\
\hline Polonium-210 & $0.03-0.5 p \mathrm{Ci}^{1}$ & $1.06-3.7$ \\
\hline Benzoic acid & $14-28$ us & $0.67-0.95$ \\
\hline Lactic acid & $63-174$ ys & $0.5-0.7$ \\
\hline Glycolic acid & $37-126_{\text {us }}$ & $0.6-0.95$ \\
\hline Succinic acid & $112-163 u p$ & $0.43-0.62$ \\
\hline
\end{tabular}

'Picocurie (1 Curie $=3.7 \times 10^{10}$ Becquerel) 
power plants, domestic heating systems, petrol and diesel engines, refuse burning and various industrial activities (33).

Thus far, more than 500 individual PAH have been identified (34). However, only a limited number of them could exhibit carcinogenicity in the tested systems. Tobacco smoke contains several potent carcinogenic PAH for which benzo[a]pyrene (B[a]P) is widely known as the representative compound (32). Chemically, PAH are relatively inert as they are formed at very high temperatures. Being lipid soluble, PAH tend to accumulate in organisms, which come into contact with them. They may subsequently undergo metabolization yielding highly reactive electrophiles or water-soluble derivatives. The formers, if not eliminated in time, can interact with cellular structures and molecules and initiate carcinogenesis. Paradoxically, it is now known that if PAH were not metabolized, they would not be carcinogenic (35).

\subsubsection{Biotransformation of Polycyclic Aromatic Hydrocarbons}

Upon entering the body, PAH are enzymatically transformed to a series of excretable endproducts [detoxification] or highly reactive metabolites interacting with subcellular targets [activation] (35). The initial step is epoxidation, which is the addition of one atom of oxygen across a double bond. This reaction is usually catalyzed by cytochrome P-450 (CYP-450) enzymes, encoded by the CYP family of genes (36). Other enzymes such as lipoxygenase, cyclooxygenases, myeloperoxidases and monoamine oxidases, are also involved, but to a lesser extent $(37,38)$. The epoxides can undergo (I) hydration to yield diols [catalyzed by epoxide hydolases (EH)], (II) isomerization to phenol or (III) conjugation with glutathione (GSH) [catalyzed by glutathione $S$-transferases (GSTs)] (35). The diol derivatives can conjugate to glucuronic and sulfuric acids [catalyzed by uridine-5' -diphosphate-glucuronosyltransferases (UGT) and sulfatases, respectively] $(37,38)$ or further be oxidated/hydoxylated to yield diol epoxides (39). Subsequently, the diol epoxides may undergo conjugation with GSH (40) or further metabolization to triols and tetraols or interaction with macromolecules forming e.g., DNA adducts (41). Likewise, the phenol derivatives can conjugate to glucuronic and sulfuric acids or be further metabolized to adduct forming intermediates (42). The metabolic pathway of the model PAH compound, B[a]P, is simplistically outlined in Figure 1.

Stereoisometrically, most PAH derivatives exist as pairs of enantiomers [anti or syn], two compounds related to one another as non-superimposable mirror images. Physically, each member of a given pair differs from its antipode in the direction by which it rotates the plane of polarized light [ + or -$]$, and also in the absolute configuration of groups around a chiral center ( $R$ or $S$ ) (43). Biologically, two members of a pair of enantiomers may exhibit large differences both in terms of their activity and in the details of their metabolism (44). For example, the 7,8-diol 9,10-oxide-B[a]P (BPDE), generally regarded as the ultimate carcinogenic form of $\mathrm{B}[\mathrm{a}] \mathrm{P}$, is produced as two diastereomers, each comprising two enantiomers. Of these four, the (+)-anti-7R,8S-dihydroxy-9S,10R-epoxy-7,8,9,10-tetrahydro$\mathrm{B}[\mathrm{a}] \mathrm{P}((+)$-anti-BPDE) has been found to possess greater biological activity than the other three in most test systems (45). The (+)-anti-BPDE at C-10 position can bind covalently to 2amino group of guanine, thereby forming a major DNA adduct, (+)-anti-BPDE-dG (46). 


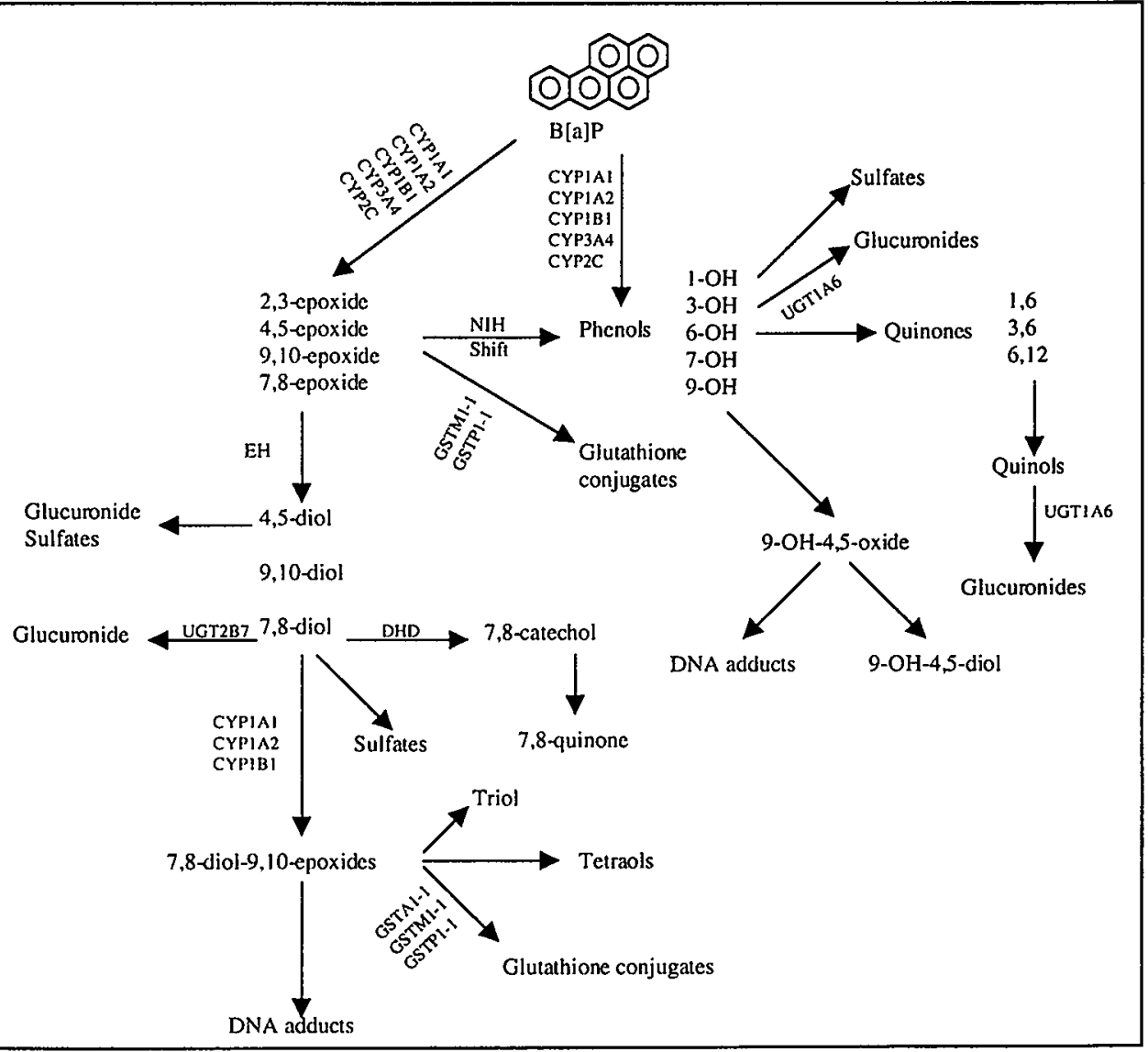

Figure 1. Metabolic pathways of benzo[a]pyrene (B[a]P), adapted from ref. (41). Major enzymes involved in these reactions are indicated as CYP, cytochrome P-450; DHD, dihydrodiol dehydrogenase; $\mathrm{EH}$, epoxide hydrolase; GST, glutathione $S$-transferases; UGT, uridine-5'-diphosphate-glucuronosyl-transferases; 1-OH, 1hydroxy $B[a] P$, etc. Other abbreviations are defined in the text.

\subsubsection{Epidemiological and Biological Data on Polycyclic Aromatic Hydrocarbons}

In 1775, Percival Pott noted a high incidence of skin cancer in chimney sweeps probably induced by $\mathrm{B}[\mathrm{a}] \mathrm{P}$, which occurs at a concentration of $0.2 \%$ in the soot. Around a century later, von Volkman demonstrated the link between skin cancer and exposure to PAH in German coal tar workers (47). In 1947, Kennaway showed the high risk of lung cancer in workers of coal tar and gas industries (47). This was well extended in 1972 by Sir Richard Doll who made a longitudinal study of mortality in workers of the same industries. Subsequent studies in occupationally or medically or environmentally exposed individuals to PAH implicated 
these compounds in the etiology of several human cancers including cancers of the lung, oral cavity, larynx, skin, stomach, rectum, cervix and breast (23). The history of the evaluation of PAH has been extensively reviewed by Sir Emest Kennaway (48).

Thus far, the involvement of PAH in smoking-associated cancers in humans has been investigated in the target organs [tumor arising organs] or in the surrogate matrices such as peripheral blood cells $(49,50)$. The latter has been used mainly in studies where the population under investigation consists of healthy individuals. Conceivably, most target organs for smoking-related cancers are not readily obtainable and require surgical or somewhat invasive procedures that preclude, for practical or ethical reasons, widespread populations sampling or repeated sampling of the same individuals $(50)$.

LUNG: In the lung, dosimetry of aromatic-DNA adducts has consistently shown a higher level of adducts in smokers as compared to non-smokers (51-54). In the ${ }^{32} \mathrm{P}$ postlabeling analyses, smokers show a typical diagonal radioactive zone (DRZ) generated by the resolution of labeled DNA digests on 2-dimensional thin-layer chromatograms with conventional urea solvent systems. This is widely thought to indicate that a complex mixture of adducts are formed in the respiratory tract after exposure to tobacco smoke (50). More recently, ammonium hydroxide-based thin layer chromatography solvents have been introduced, which resolve adduct DRZ into discrete spots and allow determination of adducts derived from various classes of compounds including PAH (55). The PAH-derived nature of DNA adducts in smokers lung is shown by the specific detection of BPDE-dG adducts using fluorescence spectrometry and enzyme-linked immunosorbent assay (ELISA) $(53,56)$. However, the non-urea-based ${ }^{32} \mathrm{P}$-postlabeling analysis failed to demonstrate any typical PAHDNA adducts in the smokers lung (57).

More mechanistically, distribution of $( \pm)$-anti-BPDE-dG adducts has been mapped within the $P 53$ tumor suppressor gene, which is mutated in $60 \%$ of human lung cancers (58), in both HeLa cells and normal human bronchial epithelial cells (28). Accordingly, it has been shown that this major adduct of PAH is preferentially formed at lung cancer mutational hotspots [codon 154,157, 158, 245, and 273 (58)] (28). Recently, the distribution of other active diol epoxides of smoke-related PAH [chrysene, 5-methylchrysene, 6-methylchrysene, benzo[c]phenanthrene and benzo[g]chrysene] has also been mapped in normal human bronchial epithelial cells (59). Interestingly, the DNA damage induced by these compounds mapped partially to the same codons previously reported for ( \pm )-anti-BPDE. This indicates that other PAH also contribute to the total load of adducts in the P53 gene and probably, impact upon its mutational spectrum (59).

LARYNX: In the larynx, aromatic-DNA adducts have been detected in smokers but not in non-smokers by both enrichment methods of the ${ }^{32} \mathrm{P}$-postlabeling assay, the nuclease P1 (NPI) digestion and the butanol extraction methods (60). Applying the NP1 version of this assay, Szyfter et al. (61) demonstrated the formation of aromatic/hydrophobic DNA adducts in both tumor and non-tumor larynx tissues whilst adduct levels were higher in the former tissues. Analysis of the laryngeal tumors by single-strand conformation polymorphism (SSCP) and direct DNA sequencing of exons 5-8 revealed that $46 \%$ of the mutations detected in these tissues were the typical P53 mutations observed in lung cancer [G $\rightarrow T$ transversions, and $\mathrm{G} \rightarrow \mathrm{A}$ and $\mathrm{C} \rightarrow \mathrm{T}$ transitions (62)]. Additionally, $54 \%$ of the detected mutations were within the hotspot region of the $P 53$ gene covering codons 238-248 (63). 
ORAL AND NASAL CAVITY: Initial reports on dosimetry of DNA adducts in the oral mucosa cells were inconclusive both in smokers versus non-smokers and in different groups of tobacco users e.g., betel nut chewers, Khaini tobacco chewers and inverted smokers $(64,65)$. Subsequently, the NP1 and butanol enhanced ${ }^{32} \mathrm{P}$-postlabeling analyses showed the higher level of adducts in smokers' oral mucosa cells and suggested the aromatic amines and/or nitroaromatic nature of these adducts $(66,67)$. Also, immunohistochemistry of PAH-DNA adducts showed the higher level of adducts in the oral cells of smokers as compared to nonsmokers (68-70). Likewise, in the nasal epithelial cells, obtained by biopsy or nasal lavage, smokers had higher level of adducts as compared to non-smokers in the NP1 enriched ${ }^{32} \mathrm{P}$ postlabeling analyses $(71,72)$.

CERvix, PLACENTA AND SPERM: In the cervical epithelium, smokers showed higher level of adducts as compared to non-smokers in both versions of the ${ }^{32} \mathrm{P}$-postlabeling assay and the differences were more pronounced when the butanol extraction method was utilized $(73,74)$. A recent immunohistochemical study has also shown the higher level of PAH-DNA adducts in the cervical smears of smokers as compared to non-smokers (75). Also, elevated level of DNA adducts was observed in the placenta of smoking pregnant women as compared to their non-smoking counterparts by both ${ }^{32} \mathrm{P}$-postlabeling assay and ELISA (76-78). In addition, the level of adducts in umbilical cord vein was significantly lower than in placenta, and marginally lower than in umbilical cord artery in the same donor $(76,77)$. This implies a transplacental exposure of the fetus to smoke-derived carcinogens as well as its capability to metabolize these compounds. Furthermore, the ${ }^{32} \mathrm{P}$-postlabeling analysis of human sperm cells failed to differentiate between smokers and non-smokers $(79,80)$; however, pre-implemented embryos from smoking parents showed higher immunoreactivity for BPDEDNA adducts compared to those from non-smoking parents (81). Noteworthily, the similar levels of immunostaining in embryos from both types of smoking couples (either one parent smoker or both parents smokers) in this study (81), together with the relatively higher immunoreactivity for BPDE-DNA adducts in sperm cells of smokers as compared to nonsmokers in another study (82) may suggest that transmission of modified DNA is mainly through the spermatozoa.

BREAST: In a pilot study in breast cancer cases and mammoplasty controls, only breast tissues [tumor and/or tumor-adjacent] from the cases who were current smokers displayed a DRZ in the NP1 enhanced ${ }^{32} \mathrm{P}$-postlabeling analysis (83). Applying the same methodology, a large-scale case control study showed the higher level of DNA adducts in the adjacent nontumor tissues of the cases (84). However, both studies were subsequently biased because of their inappropriate controls and unadjusted confounders. Recently, a well-designed hospitalbased case control study has shown an association between immunohistochemically detected PAH-DNA adducts and breast cancer risk $(\mathrm{OR}=4.43,95 \% \mathrm{CI} 1.09-18.01)$ after controlling for known risk factors for breast cancer and adjusting for confounding factors for PAH exposure. The smoking behaviors, however, did not correlate with the level of adducts nor with the case-control status (85).

MISCELLANEOUS: Scant ${ }^{32} \mathrm{P}$-postlabeling data have shown the elevated level of DNA adducts in tumor tissues from gastric cancer patients as compared to respective controls (86). Also, in a pilot study in human colon mucosa (+)-anti-BPDE-dG adducts were detected using the high performance liquid chromatography with fluorescence detection (HPLC-FD) (50). In 
the skin, adducts measurement has been performed in relation to occupational/medical exposure to PAH rather than tobacco smoking. For example, in psoriasis patients treated with coal tar, specific nuclear staining for ( \pm )-anti-BPDE-DNA adducts detected by indirect immunofluorescence method, was observed in the skin biopsies (87). The same samples also revealed a pattern of multiple DNA-adducts in the NP1 ${ }^{32} \mathrm{P}$-postlabeling analysis (87). Similar results were reported by our group in coal tar-treated eczema patients, as well (88).

PERIPHERAL BLOOD AND BRONCHOALVEOLAR LAVAGE: In peripheral blood cells, dosimetry of PAH-DNA adducts had initially produced controversial results whilst this matrix was analyzed in its entirety [total white blood cells (WBC)] (89-91). Later, it became evident that as WBC is composed of different cell types with varying life spans and metabolizing capacities (92), both the recency of exposure and formation/persistence of adducts may vary within this matrix (93). For instance, granulocytes which comprise approximately $60 \%$ of total WBC, and have a short half-life of 7-24 h (92) had considerably lower level of PAH-DNA adducts than mononuclear cells [monocytes $\{15 \%\}$ plus lymphocytes $\{75 \%$ \} (92)] (93). Moreover, when treated separately with B[a]P in vitro, only short lived monocytes [life span: $8 \mathrm{~h}$ ], but not unstimulated lymphocytes [life span: 1-5 y], formed DNA adducts. Subsequent formation of DNA adducts in both cell types incubated simultaneously with B[a]P suggested that in vivo formation of adduct in lymphocytes occurs after other cell types activate the procarcinogens (94). Accordingly, use of total WBC for measurement of DNA adducts has been increasingly replaced by mononuclear cells adduct dosimetry. Yet, adduct measurement in the fractionated WBC is subject to bias. The fact is that circulating blood cells are exposed to diverse routes of exposure, e.g., inhalation, ingestion and dermal absorption, thereby reflecting an integrated rather than a specific body burden for DNA adducts. This liability is of most concern when the carcinogen of interest enters the body via a specific route. Such non-specificity of DNA adducts in WBC may explain the controversy on PAH-DNA adducts in WBC of smokers versus non-smokers, and of other groups of PAH-exposed versus non-exposed individuals $(49,50)$. With the same token, the lack of correlation between the level of adducts in WBC and target organs is somehow expected (49,50). Interestingly, few studies (95-97) have utilized bronchoalveolar lavage (BAL) cells, which are mainly [>90\%] composed of bronchoalveolar macrophages (BAM) with an efficient metabolic machinary and predominant exposure to inhalatory carcinogens $(98,99)$. Although adduct analyses in the BAL cells have been much more promising than those in WBC, the invasiveness of the method of sampling hinders routine application of the BAL cells in molecular dosimetry studies.

GENOTYPING AND PHENOTYPING OF BIOTRANSFORMATIONAL ENZYMES: A complementary area of interest is the polymorphisms of genes involved in biotransformation of PAH. The enzyme complex responsible for the initial activation of PAH, arylhydrocarbon hydroxylase (AHH), consists of a battery of enzymes that include CYPIAl (100). The CYP1A1 mRNA reflects gene induction while AHH and 7-ethoxyresirufun $O$ deethylase (EROD) are measures of enzyme activity $(101,102)$. Among the four known polymorphisms identified in the CYPIAI gene two closely linked mutations [mostly in Asians] have been extensively studied in relation to $\mathrm{AHH}$ inducibility, DNA damage and cancer risk, one that results in a new restriction site [MspI] in the $3^{\prime}$-untranslated region of the gene, the $C Y P I A I * 2$ allele, and another located in exon 7 , which results in an amino acid 
exchange [isoleucine (Ile) $462 \rightarrow$ valine (Val)], the CYPIAl $* 3$ allele $(103,104)$. These alleles have, in most studies but not all, been associated with increases in the catalytic activity of the enzyme and with higher AHH inducibility $(101,102)$. The alleles have also been associated with increased frequency of the P53 mutations in lung and oral tumor tissues $(105,106)$. The extent of $\mathrm{AHH}$ activity in human lung microsomes has been positively correlated with the level of PAH-DNA adducts in the same lung samples (52). In the leukocytes, however, such correlation has not been shown consistently $(107,108)$. Regarding the CYPIA1 polymorphism and susceptibility to DNA damage or cancer, contradictory results have been reported. This has mostly been the case when different populations with varying mutated allele frequencies were investigated, or when the analyses were performed in the surrogate tissues $(49,50)$. Overall, lack of agreement in these studies may have arisen from the differences in experimental approaches to determining polymorphisms, to detecting DNA adducts within specific organs and to demonstrating subtle effects whilst having incomparable statistical power.

A major pathway of detoxification for PAH is formed by the multi-gene family of cytosolic enzymes, the GSTs. These enzymes catalyze the conjugation of PAH or their reactive metabolites to GSH, thereby making them readily excretable (109). Four different families of GSTs are known, $\alpha, \mu, \pi$ and $\tau(110)$ although it is mostly GST $\mu$ and GST $\pi$ for which relevant literature with regard to PAH and cancer is available. Each GST family comprises several genes e.g., the GST $\mu$ consists of at least five known genes, GSTMI-5 (110). The various GSTs have different but often overlapping substrate specificities (110). Also, diverse patterns of expression in different cells and tissues are known (110). The most studied human GST, GSTM1, is lacking in approximately $50 \%$ of Caucasian populations (111). The absence of enzyme is caused by an 8-kb deletion at the entire coding region of the GSTMI gene, rendering the null genotype (111). A meta analysis of 12 case control studies has concluded that the GSTM1 null genotype is a moderate risk factor for lung cancer ( $O R=1.41$, 95\% CI 1.23-1.61; P<0.0001) (112). This genotype has also, in some studies but not all, been associated with an increased incidence of other types of cancer e.g., adenocarcinoma of stomach and caecum, multiple skin cancers, carcinoma of bladder and oral nasopharyngeal and laryngeal cancer (106,113-115). Additionally, it has been shown that possession of GSTMI null genotype may affect the susceptibility to DNA damage in various organs (116-118). A number of studies have reported the association between GSTMI null genotype and the level of PAH-DNA adducts in non-tumorous tissues of lung cancer cases $(116,119,120)$. However, the influence of this genotype on DNA adduct levels in leukocytes is not clear, yet. Studies of occupationally or environmentally or medically PAH-exposed subjects e.g., chimney sweeps, coke oven and foundry workers, bus drivers, fire-fighters, soldiers, coal tar-treated patients as well as of smokers have mainly shown no or an insignificant increase in leukocytes DNA adduct levels dependent on GSTMI null genotype $(117,121,122)$.

The GSTPI gene is also known to be polymorphic at different sites (123). A common polymorphism occurs in exon 5 of this gene causing an exchange of amino acid [lle $105 \rightarrow$ Val] with a mutant frequency of $30-35 \%$ (124). As a result, both isoforms, GSTP1-1/V-105 [GG: Val/Val, GA: Ile/Val] and GSTP1-1//-105 [AA: Ile/lle], differ in activity, specificity and catalytic efficiency $(123,125)$. Epidemiological studies indicate that individuals carrying the GSTPI-IN-105 rather than GSTP1-1/I-105 allele, are more susceptible to tumor formation at 
sites like oral cavity, esophagus, breast, bladder and testis (126-128). Besides, the levels of hydrophobic-DNA adducts in non-cancerous lung tissues from smoking lung cancer patients have been shown to be associated with GSTPI-IN-105 genotype (120). Still, studies of GSPI polymorphisms in relation to $\mathrm{PAH}$ exposure are too few and limited to allow any definite conclusion.

Overall, it appears that a combination of different metabolic polymorphisms rather than a single one, is a better determinant of DNA damage and cancer susceptibility. For instance, in a study of non-small cell lung cancer (NSCLC), the prevalence of combined GSTMI null and $C Y P 1 A I * 2 B$ genotypes was significantly higher in the adenocarcinoma group (129). In the same study, patients with the GSTMI null and CYPIAl*3 combined genotypes had significantly higher level of PAH-DNA adducts in non-tumorous tissues of the lung as compared to those with other genotype combinations (129). Also, smoking lung cancer patients as well as coke oven workers who had a combination of CYPIAl*2 or *3 and GSTM1 null genotypes had higher level of (+)-anti-BPDE-DNA adducts as compared to those with CYPIAI and GSTMI wild-type at a similar or even lower smoking dose (117). Furthermore, smoking individuals with mutated CYPIAI and GSTMI null genotypes had 100-fold higher level of bronchial BPDE-DNA adducts as compared to those with other combined genotypes (130). Among the moderate smokers, those who carried the combined CYPIAI*2 and GSTMI null alleles showed the highest level of adducts (108). Likewise, lung cancer patients with GSTMI null and GSTPI-IN -105 combined genotypes had the highest level of hydrophobic-DNA adducts in non-tumorous tissues of the lung (120). The distribution of combined GSTMI null and GSTPI-1/ - 105 genotypes was also significantly different in cases and controls (120). In a Japanese population, individuals who carried the mutated GSTPI and GSTMI null alleles had a higher risk of head and neck cancer as compared to those who had other combined genotypes ( $\mathrm{OR}=2.58,95 \% \mathrm{CI} 0.77-1.79)$ (131). Also, the level of PAH-DNA adducts in the mononuclear WBC of smokers with GSTMI null and GSTPI-IN-105 combined genotypes was non-significantly higher than that in smokers with other genotype combinations (122).

Taken together, the results of DNA adduct dosimetry and genotyping/phenotyping studies partially support the contribution of PAH to smoking-associated cancer in particular cancer of the lower respiratory tract in humans. The remaining uncertainties would not be resolved unless the following issues are fully addressed: (I) the ubiquity of confounding exposure to PAH (II) the complexity of exposure to a spectrum of PAH with different carcinogenic potencies (III) the statistical power criteria for genotyping/phenotyping of the relevant biotransformational and DNA repair enzymes. This together with the urge for validating the currently used surrogate matrices and/or introducing innovative biological materials would define the strategy for future research on PAH, smoking and cancer. 


\subsubsection{Aromatic Amines}

Aromatic amines (aryl and heterocyclic amines) are formed during the combustion of the tobacco product and are present in substantial amounts in its particulate phase (132). Also, a number of nitroaromatic hydrocarbons originating from a variety of combustion processes e.g., those in diesel engines, as well as a great deal of heterocyclic amines generated during high-temperature cooking processes comprise other sources of aromatic amines (133). In occupational settings, aromatic amines have long been used as antioxidants in the production of rubber and in cutting oils, as intermediates in azo dye manufacturing and as pesticides (134). Todate, aromatic amines are still a common contaminant in several working environments including the chemical and mechanic industries and aluminum transformation (135).

Tobacco smoke contains three potent carcinogenic arylamines, 4-ABP, 2-toluidine and 2naphthylamine as well as several known or probable carcinogenic heterocyclic amines e.g., 2amino-3,8-dimethylimid-azo[4,5-f]quinoxaline (MeIQx) and 2-amino-1-methyl-6-phenylimidazo[4,5-b]pyridine (PhIP) (133). Of these, 4-ABP is the subject of most concern due to the facts that (I) it is one of the most potently carcinogenic aromatic amines, and (II) it has the highest covalent binding index among different aromatic amines; it appears to have the strongest ability to form adducts with $\mathrm{Hb}$ and DNA (133).

\subsubsection{Biotransformation of Aromatic Amines}

As a model compound, 4-ABP has been extensively studied to elucidate the pathway of biotransformation for aromatic amines (133). Basically, if not detoxified via $N$-acetylation or $O$-acetylation [catalyzed by $N$-acetyltransferases (NAT1 or NAT2)] (136), 4-ABP undergoes $N$-oxidation [catalyzed by CYP1A2] to yield $N$-hydroxy-4-ABP $(136,137)$. This hydroxylamine is also generated via $N$-methylation and peroxidation catalyzed by $N$ methyltransferases and prostaglandin $H$ synthase, respectively, but to a lesser extent $(138,139)$. The $N$-hydroxy-4-ABP has different fates; it can undergo cooxidation with oxyhemoglobin yielding methemoglobin and $N$-nitrosobiphenyl (140). The latter can react with sulfhydryl group in hemoglobin $(\mathrm{Hb})$ at cysteine $\beta-93$ site forming a biologically stable sulfinamide adduct, commonly abbreviated as $4-\mathrm{ABP}-\mathrm{Hb}$ adduct (141); this adduct accounts for $2-10 \%$ of the $4-A B P$ dose (142). It can also be converted back to $N$-hydroxy-4-ABP inducing another cycle of methemoglobin formation (141). The $N$-hydroxy-4-ABP can also be transported directly or in conjugation with glucuronic acid [catalyzed by $N$-glucuronosyl transferases] to the bladder where it is hydrolyzed at $\mathrm{pH} 6.0$ of urine (143). The resultant can form 4-ABP-Hb adducts or various DNA adducts including $N$-(deoxyguanosin-8-yl)-4-ABP [70\%], $N$-(deoxyadenosin-8-yl)-4-ABP [10\%] and $N$-(deoxyguanosin- $N^{2}$-yl)-4-ABP [5\%] (144). Figure 2 depicts the simplified metabolic pathway of 4-ABP. 


\subsubsection{Epidemiological and Biological Data on Aromatic Amines}

In 1895 , Rehn reported an increased incidence of urinary bladder cancer in German dyestuff workers (145), which according to Leichtenstren could be ascribed to their exposure to naphtalimines (146). Epidemiological studies followed this report immediately, and showed the link between the exposure to 2-naphthylamine, benzidine and 4-ABP and human bladder cancer (147). The carcinogenicity of 2-naphthylamine to the urinary bladder was not demonstrated until 1938 (148), followed by benzidine in 1950 (149) and 4-ABP in 1954 (150). Based on these epidemiological and experimental findings, the industrial use of carcinogenic aromatic amines and their nitro analogues was curtailed in most parts of the world (151).

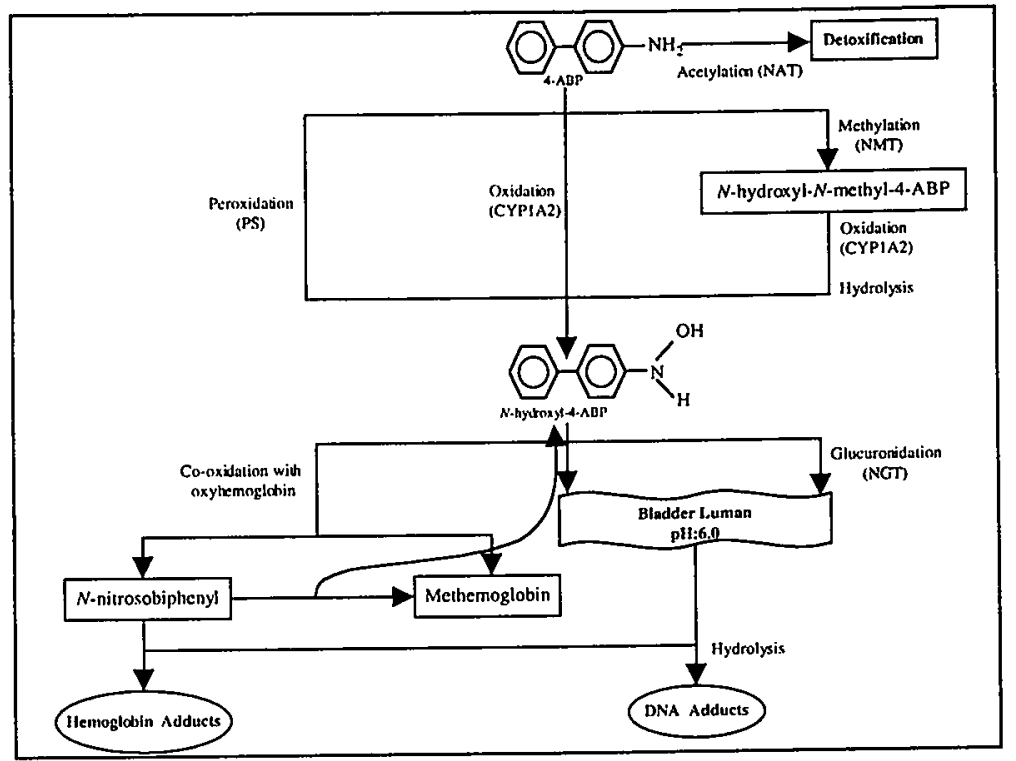

Figure 2. Metabolic pathways of 4-aminobiphenyl (4-ABP), modified from ref. (133). Major enzymes involved in these reactions are indicated as CYP, cytochrome P-450; NGT, N-glucuronosyl transferases; NMT, $N$-methyltransferases; NAT, $N$-acetyltransferases; PS, prostaglandin $H$ synthase.

In 1972, Doll et al. (152) suggested that the concentration of 2-naphthylamine in tobacco smoke [from blond British cigarettes] was comparable to concentrations found in coalcarbonizing plants where an excess of bladder cancer was identified. Subsequently, chemical analyses showed 2 - 5 times higher levels of various aromatic amines in black [burley or aircured] tobacco than in blond [bright or flue-cured] tobacco $(153,154)$. Epidemiological studies reinforced these findings by showing the association between urinary bladder cancer and tobacco smoking; it has been reported that $50 \%$ of male and $25 \%$ of female urinary bladder cancer cases in western countries are attributable to smoking $(155,156)$. Case-control studies have also confirmed that the relative risk of urinary bladder cancer for smokers of black tobacco is $2-3$ times higher than that for smokers of blond tobacco (157-159). 
In molecular dosimetry studies, it was shown that for the same amount of smoking, black tobacco smokers had 1.5 times higher levels of 4-ABP-Hb adducts and excreted 1.8-fold higher levels of urinary mutagens characterized as aromatic amines $(142,160)$. Using the ${ }^{32} \mathrm{P}$ postlabeling assay, Talaska and co-workers identified the $N$-(deoxyguanosin-8-yl)-4-ABP adduct as a major smoking-related DNA adduct in bladder biopsies from surgical patients (161). Elevated levels of this adduct were observed in specimens of urothelial bladder cancer patients who were active smokers as compared to non- and ex-smoking controls (161). Likewise, a study in smoking patients with transitional cell bladder carcinoma showed the higher level of 4-ABP-Hb adducts measured by capillary gas-chromatography and negativeion chemical ionization mass-spectrometry (NICI-GC-MS), as compared to the respective controls (162). Applying the same methodology, healthy smokers had higher level of 4-ABP$\mathrm{Hb}$ adducts than non-smokers, and the levels of adduct in non-smokers were dosedependently related to ETS (163). In smoking volunteers, the $N$-(deoxyguanosin-8-yl)-4-ABP adduct was tentatively identified in the exfoliated urothelial cells using the ${ }^{32} \mathrm{P}$-postlabeling assay (164). Whilst the levels of this major DNA adduct were significantly and linearly correlated to the levels of 4-ABP-Hb adducts, both were dose-dependently related to smoking intensity (164). Immunohistochemically, higher levels of 4-ABP-DNA adducts were observed in oral and urothelial and laryngeal cells of smokers as compared to non-smokers; however, no dose-response relationship could be established in either cell type $(68,165,166)$.

Inferences about aromatic amines and smoking-associated bladder cancer have also emerged from genotyping and phenotyping of the encoded enzymes involved in activation or detoxification of these compounds. The NAT1 enzyme, originally referred to as the monomorphic acetyltransferase, carries out the $\mathrm{N}$-acetylation of aromatic amines. It also catalyzes the $O$-acetylation of $N$-hydroxyarylamines and an intramolecular $N, O$-acetyltransfer reaction that converts arylhydroxyamic acids to mutagenic acetoxy esters (167). The NAT1 enzyme is expressed in bladder epithelial tissue and in cell lines derived from the bladder epithelium $(168,169)$. Currently, the $N A T I$ is known as a multi-variant gene with considerable structural differences, which can exhibit fast/slow acetylator phenotypes. A DNA sequence polymorphism in the $3^{\prime}$ untranslated region of the $\left.N A T\right]$ gene [NATI*1O genotype] has been associated with varying NAT1 enzyme activities in human tissues (170,171). Approximately $30 \%$ of populations with European ancestry inherit this genotype and show a variant polyadenylation signal in the 3'-untranslated region of the NATI mRNA (172). Tissue samples from the individuals who carried the $N A T 1^{*} I O$ allele had about 2 -fold more NAT1 enzyme activity than those homozygous for the more common $N A T I * 4$ allele (171).

The NAT2 enzyme has long been known to be polymorphic, and a great number of studies have described the molecular genetic basis for the fast/slow acetylation phenotype $(173,174)$. In humans, $N$-acetylation activity varies widely as a result of sequence polymorphism at the NAT2 locus; thus, individuals with 2 nonfunctional alleles, 'slow acetylator alleles', have little or no NAT2 enzyme activity $(173,174)$. The frequency of the NAT2 slow acetylator genotype varies between 5-90\% worldwide (175).

The CYP1A2 constitutes the primary pathway of activation for aromatic amines by catalyzing the $N$-oxidation of these compounds to $N$-hydroxyl arylamines (176). This hepatic monooxygenase, originally characterized as the phenacetin $O$-deethylase, is also known to be polymorphic in humans. The CYP1A2 exhibits wide interindividual variation, is inducible by 
cigarette smoking and is completely absent in about $5 \%$ of the Caucasian population (177). Both 4-ABP and PhIP have been shown to be excellent substrates for the CYP1A2, and have the highest turnover numbers, followed by MeIQx and 2-naphthylamine (177).

Taken together, variation in NAT1 and NAT2 as well as CYP1A2 activities in smokers may affect their risk for bladder cancer (134). Hence, smoking individuals with higher frequency of rapid $\mathrm{N}$-oxidation and slow acetylation are more susceptible for carcinoma of the bladder. In fact, the NAT2 slow acetylator phenotype has been reported to be associated about $39 \%$ more with bladder cancer than the fast acetylator phenotype (134). In smokers, the levels of 4-ABP-Hb adducts were dependant on NAT2 and CYP1A2 phenotypes, adduct levels being 1.3- to 1.5-fold lower in fast acetylators and slow/intermediate oxidizers (178). Also, rapid oxidizers and the combined slow acetylator-rapid oxidizer phenotypes had the highest 4$\mathrm{ABP}-\mathrm{Hb}$ adduct levels at a low smoking dose (179). More mechanistically, slow acetylator NAT2 polymorphisms have been shown to influence the type of P53 mutation acquired in bladder cancer (180). Also, loss of heterozygosity (LOH) for both NATl and NAT2 have recently been shown in epithelium-derived tumors of bladder cancer patients using the fluorescence in situ hybridization (FISH) technique (181,182). Altogether, results from the epidemiological and molecular dosimetry studies reinforce the view that aromatic amines are primarily responsible for smoking-associated bladder cancer in humans.

\subsubsection{Reactive Oxygen Species}

Several constituents of the vapor and particulate phases of tobacco smoke form ROS (183). These include oxygen-centered radicals such as superoxide anion $\left(\mathrm{O}^{\circ}{ }_{2}\right)$, hydroxyl $\left(\mathrm{OH}^{\circ}\right)$, alkoxyl $\left(\mathrm{RO}^{\circ}\right)$ and peroxyl $\left(\mathrm{RO}_{2}^{\circ}\right)$ as well as nonradical compounds such as hydrogen peroxide $\left(\mathrm{H}_{2} \mathrm{O}_{2}\right)$, singlet oxygen $\left({ }^{+} \mathrm{O}_{2}\right)$ and ozone $\left(\mathrm{O}_{3}\right)$. Also, hydroquinone and catechol [present in the particulate phase] can redox-cycle to form $\mathrm{O}_{2}^{\circ}$ and $\mathrm{H}_{2} \mathrm{O}_{2}$ (184). It has been shown that both MS and SS vapor phase smoke contain the same amount of free radicals, mainly $\mathrm{RO}_{2}{ }^{\circ}$ and $\mathrm{RO}^{\circ}$ with a concentration of $1 \times 10^{16}$ per cigarette or $5 \times 10^{14}$ per puff (185).

ROS can attack cellular structure or molecules; however, with respect to carcinogenesis DNA is the prime target (186). Thus, ROS may cause DNA-protein cross links, sugar moiety damages and specific chemical modifications of the purine and pyrimidine bases (187). Oxidation of the sugar moiety induces base release and strand breaks $(188,189)$ whereas oxidative base modifications and cross links result in mutations (187).

\subsubsection{Biotransformation of Reactive Oxygen Species}

Superoxide anion radical can be broken down by superoxide dismutase (SOD) resulting in the formation of hydrogen peroxide. Hydrogen peroxide may in turn, be reduced to water by glutathione peroxidase (GP) or catalase. Hydrogen peroxide has limited reactivity whilst crossing the membranes quite easily. In the presence of transition metals e.g., $\mathrm{Fe}^{2+}$ and $\mathrm{Cu}^{+}$, 
hydrogen peroxide is reduced to hydroxyl radicals, the proximal agent of much oxidative damage (186). Hydroxyl radicals react avidly with all components of DNA (190) but sacrificial defenses exist in the form of small molecules such as GSH and $\alpha$-tocopherol, which stop free radical chain reactions (191). The hydroxyl radicals escaped from such antioxidative defense line, can damage the deoxyribose, and purine and pyrimidine bases as well as generate crosslinks between DNA and proteins (187).

Thus, hydroxyl radicals abstract hydrogen atoms from deoxyribose yielding sugar radicals that can fragment in various ways. Reactions of deoxyribose-derived radicals can lead to the release of purine and pyrimidine bases from DNA producing apurine and apyrimidine sites (AP sites/abasic sites), thereby making strand breaks. Some of the altered sugar radicals that remain attached to DNA can also split and give strand breaks by incubation with alkalilabile sites (188).

Although hydroxyl radicals can cause multiple damages to all four bases $(192,193)$, those to guanine are of most importance because of their known mutagenicity in experimental models $(194,195)$. As such, hydroxyl radicals can bind to guanine residues at C-4, C-5, and C8 positions. For example, addition of hydroxyl radicals to $\mathrm{C}-8$ of guanine produces a radical adduct $\left(\mathrm{G} \mathrm{OH}^{\circ}\right)$ that has several fates. It can be reduced to 8-hydroxy-7,8-dihydroguanine (8$\mathrm{OH}-\mathrm{dG}$ ), oxidized to 8-oxo-7,8-dihydroguanine (8-oxo-Gua), or undergo ring opening followed by one-electron reduction and protonation to give 2,6-diamino-4-hydroxy-5formamidopyrimidine (FapyGua) (196). Of these, 8-oxo-Gua is the lesion of most concern because it mispairs with adenine during replication giving rise to $G \rightarrow T$ transversions (195).

Evolutionary, all oxidative DNA lesions are subject to a complementary repair system (197). This system primarily functions through the activity of base excision repair (BER) enzymes (198). Examples of these enzymes are formamidopyrimidine glycosylases (Fpg), which remove FaPyGua, FaPy adenine and 8-oxo-Gua lesions, and 7,8-dihydro-8-oxo-2'deoxyguanosine-glycosylase/apurinic lyase $(O G G 1)$, which excises 8-oxo-Gua and FaPyGua lesions and subsequently, incises the AP sites in the damaged DNA $(199,200)$. The repair products are mostly water-soluble and readily excreted into the urine $(199,200)$.

Lastly, radical attacks may generate cross links between DNA and proteins within the same chain [intra-strand] or between different chains [inter-strand] $(201,202)$. Studies with model compounds have suggested the oxidative formation of such damages between nearby purines (203). Presumably, the repair of these lesions would recruit recombinational repair for which the detailed mechanisms in mammalian cells are not fully understood, yet (197).

\subsubsection{Epidemiological and Biological Data on Reactive Oxygen Species}

In 1954, Gerschman et al. (204) proposed that the damaging effects of $\mathrm{O}_{2}$ e.g., the induction of retrolental fibroplasia in the premature babies treated with high concentrations of $\mathrm{O}_{2}$ in incubators, could be ascribed to its capability to form ROS. This hypothesis was popularized and converted into the SOD theory of $\mathrm{O}_{2}$ toxicity following the discovery of SOD enzymes by McCord and Fridovich (205). The theory states that $\mathrm{O}_{2}$ exerts its toxicity through excess formation of $\mathrm{O}^{\circ}$, and that the SOD enzymes constitute an important antioxidant defense 
system by removing the $\mathrm{O}_{2}$ (205). Subsequently, it was suggested that the accumulation of oxidized DNA in mitochondria of muscle cells might be involved in muscle weakness acquired during aging (206). Later, the age-related declining function of other organs such as the kidneys, was also ascribed to the accumulation of oxidative DNA modifications within them (207). Todate, many other age-related degenerative diseases including arthritis, atherosclerosis, heart disease, and cataract as well as cancer are thought to involve ROS-related cellular damages in their pathogenesis (208).

Unlike PAH and aromatic amines, ROS have not been satisfactorily scrutinized for their involvement in smoking-associated cancers in humans. There are two reports that show a higher level of 8-OH-dG in non-tumorous lung tissues of smoking lung cancer patients as compared to non-smoking controls $(209,210)$. A recent study, however, failed to differentiate between the level of 8-OH-dG in normal and tumorous tissues of the lung and across different tumor types (211). Unfortunately, no relationship could be sought between the level of adducts and smoking status in this study because of the lack of data on smoking behaviors (211). Likewise, dosimetry of oxidative DNA damage in leukocytes or isolated lymphocytes of smokers versus non-smokers have not been conclusive (212,213). Apparently, the conflicting results in these studies arise from the insensitivity and/or aspecificity as well as the incomparability of the methodological approach to analyze and quantitate oxidative DNA lesions. Apart from these methodological pitfalls, the uncontrolled confounding factors such as race, age, gender and smoking intensity in most studies seem to be responsible, at least partially, for the controversial results.

Regarding the antioxidative defense pathway, the primary intracellular antioxidant enzymes, SOD and catalase, which are expressed at low levels in human airway, are not likely to be induced by oxidative stress. In fact, exposure of healthy volunteers to $100 \% \mathrm{O}_{2}$ for 12 $18 \mathrm{~h}$ did not induce the intracellular level of SOD or catalase (214). This was confirmed in an animal model when the prolonged exposure to cigarette smoke did not increase the intracellular levels of these enzymes in rat lungs (215). Extracellularly, however, the level of major antioxidant of lung epithelial lining fluid, GSH, along with GP activity and expression, increased significantly in smokers as compared to non-smokers (216). The correlation between the levels of increase in GSH and GP observed in this study indicates a coordinate augmentation of the glutathione antioxidant system in the respiratory tract after smokingimposed oxidative stress. In plasma, however, the antioxidants scavenging capacity measured by total radical trapping antioxidant potential (TRAP) or trolox equivalent antioxidant capacity (TEAC) assays, has inconsistently been shown to be modulated by smoking-induced oxidative stress (217,218). Apparently, the up- or down-regulation of plasma antioxidants in smokers observed in different studies might be due to other influential factors rather than smoking. Using a different approach, some studies have investigated the impact of smoking-induced oxidative stress on DNA repair pathway. This has been done by genotyping or phenotyping of the enzymes involved in the repair of oxidized DNA or by quantifying the repair products excreted in urine. Understandingly, the interpretation of the results from these studies is not always straightforward. The uncertainty arises from (I) the complexity of DNA repair pathway for oxidized DNA damages (198), (II) the multiplicity of oxidative DNA lesions (219), (III) the aspecificity of some of the utilized biomarkers (220) and finally, (IV) the low frequency of some polymorphic genes involved in the repair process $(211,221,222)$. For example, in the 
study of Hall et al. (223) smokers had higher level of Fpg activities than non-smokers; however, these DNA glycosylases are the first line of defense in a multi-step pathway to repair 8-oxo-Gua, FaPyGua and FaPy adenine lesions, and are not necessarily involved in the ratelimiting step of the entire repair process. Therefore, whilst their activity and/or expression may influence the dosimetry of certain DNA adducts, they will not give a measure of overall efficiency of the repair system for such DNA damages. Another example is that in in vitro systems multi variant products of hOGGI differently repair 8-oxo-Gua lesions (224); however, there has not been any association between the polymorphic variants of this gene and the level of 8-OH-dG in in vivo studies (211). Regarding the repair product of oxidized DNA, both urinary $8-\mathrm{OH}-\mathrm{Gua}$ and $8-\mathrm{OH}-\mathrm{dG}$ levels have been shown to be modified differently by smoking-imposed oxidative stress (225-227). The discrepancy between the results might be ascribed to the facts that (I) the applied methodological approach in different studies have varying sensitivity and specificity for quantification of urinary 8-OH-Gua or 8-OH-dG and (II) the urinary excretion of 8-OH-Gua reflects the repair of damaged DNA as well RNA, and also can be affected by exogenous DNA e.g., from diet (220).

Taken together, it appears that the methodology of oxidative DNA damage/repair and antioxidative defense mechanisms requires more maturation before it can resolve the dilemma of the involvement of ROS in smoking-associated cancers in humans.

\subsection{Induced Sputum for Studying Tobacco Smoke Carcinogenicity}

Respiratory mucous secretions represent a complex mixture of the secretory products from the variety of cell types located at various anatomical sites within the wall of the respiratory tract. 'Sputum' is defined as the combination of these heterogeneous secretions diffused over the luminal surface of the trachea-bronchial tree, and the exfoliated and infiltrated cells into these secretions. The complex is propelled cephalad by ciliary activity to the oral cavity where it is swallowed or alternatively expectorated $(228,229)$. The gross appearance of sputum is that of a semi-solid substance of gelatinous consistency. It is shapeless, of varying color, translucent or cloudy [depending on the disease status], and has a meshlike appearance inside of which there are embedded particles, debris, granules and cells (230). Sputum has been in clinical practice since the last half of the $19^{\text {th }}$ century when its macroscopic and microscopic examinations were used for diagnosis of asthma (231). In 1958, Morrow Brown proposed the use of sputum cytology for assessing airway inflammation by showing the presence of eosinophils in a crude Leishman-stained sputum smear of patients whose wheeze was responsive to corticosteroids (232). Three decades later, two methodological breakthroughs raised a renewal of interest in this matrix (233). The development of non-invasive induction technique was the first breakthrough, which made it possible to obtain sputum from individuals unable to produce it spontaneously (234). The second major breakthrough was the application of mucolysis agents in sputum processing, which enabled high quality analysis of the specimens (235). Accordingly, sputum re-emerged in the clinical research for investigation of a variety of airway complications. Hypothetically, sputum is unique for studying tobacco 
smoke carcinogenicity as it is a non-invasively obtainable matrix originating from the vicinity of a prime target site for smoking-associated cancers, the lower respiratory tract $(13,14)$.

\subsection{Scope of the Thesis}

Of over 4000 chemicals present in tobacco smoke, around 50 including PAH, aromatic amines and ROS have shown mutagenicity and carcinogenicity in experimental models and/or humans (1). The sequential mode of action for these compounds is as follows: uptake by the body, biotransformation into reactive metabolites, formation of DNA adducts, genetic alterations via e.g., oncogene activation, and tumor suppressor gene inactivation and eventually, induction of malignant tumors (26-29). Generally, smoking-associated carcinogenesis can be explored by monitoring the chain of events initiating from the exposure to tobacco smoke to the ultimate stage of tumorgenesis. However, the events close to the end of this continuum are of most significance as they not only indicate an already existed exposure, but they also imply a more tangible risk. By definition, investigation of this spectrum of events is called biomonitoring and the stages within this spectrum are known as markers (236,237). Ideally, biomonitoring of smoke-associated carcinogenesis should be done within the organ wherein tumor arises [target organ]. In reality, however, inaccessibility of target organs in a noninvasive fashion and on a routine basis makes such practice infeasible $(237,238)$. Also, commonly used non-target matrices e.g., blood and urine show inconsistent surrogacy for the target organs $(238,239)$.

The present thesis explores tobacco smoke carcinogenicity in target and surrogate tissues of humans by dosimetry of PAH- aromatic amine- and ROS-induced DNA adducts. Chapter 2 examines the applicability of induced sputum, a non-invasive derivative from the lower airway, for smoke-related DNA adduct analysis. Chapter 3 is a validation study on induced sputum DNA adducts, and also a comparative analysis on dosimetry of DNA adducts in induced sputum and peripheral blood lymphocytes. Chapter 4 identifies the class of smokerelated DNA adducts in induced sputum by immunohistochemistry of PAH- and aromatic amine-DNA adducts, separately. Chapter 5 examines the relevance of smoke-related DNA adduct analysis in induced sputum and PBL for assessing exposure to ETS. Chapter 6 investigates the validity of markers of oxidative DNA damage/repair as well as antioxidative defense mechanisms for studying tobacco smoke carcinogenicity in humans. Chapter 7 evaluates the predictive value of DNA adducts for cancer by dosimetry of DNA adducts in different regions of oral cavity with varying cancer susceptibility profiles. Chapter 8 applies the biomonitoring of various smoke-associated markers in a chemoprevention trial on $\mathrm{N}$ acetyl-L-cysteine (NAC). Finally, Chapter 9, discusses the overall results of the preceding chapters, summarizes the findings, and makes recommendations for future research.

$* * * * * * * * *$ 


\section{REFERENCES}

1. Hoffmann, D. and Hoffmann I. (1997) The changing cigaretce, 1950-1995. J Toxicol Environ Health, 50, $307-$ 364.

2. Tso, T.C. (1990) Production, physiology and biochemistry of tobacco plant. Idcals, Beltsville, MD.

3. Lee. P.N. (1975) Tobacco consumption in various coumtries (4th edn). Tobacco Research Council, London.

4. US Department of Health Education and Welfare. Public Health Services (1964) Smoking and Health Report of the Advisory Commiltec to the Surgeon General of the Public Health Services. Public Health Service Publication, Washington D.C.

5. European Bureau of Tobacco and Smoking Prevention (1994) Tobacco and Health in the European Union: An Overvicw, Brussels (Belgium).

6. Giovino, G.A.. Schooicy M.W.. Zhu B.P., Chrismon J.H., Tomar S.L., Peddicord J.P., Merrit R.K., Husten C.G. and Eriksen M.P. (1994) Surveillance for selected tobacco-usc bchaviors-United States, 1900-1994. Mor Mortal Wkly Rep CDC Surveill Sumu, 43, 1-43.

7. World Health Organization (1997) Smoking prevalence. In World Hcalth Organization (ed.), Tobacco or Health: a global status report. Vol. I. World Health Organization, Geneva, pp. 10-18.

8. World Health Organization (1997) Tobacco consumption. In World Health Organization (ed.), Tobacco or Health: a global stutus report. Vol. 1. World Health Organization, Geneva, pp. 19-30.

9. Morb Mortal Wkly Rep (1998) Tobacco use among high school students-United States, 1997. Morb Mortal Wkly Rep, 47, 229-233.

10. Landis. S.H., Murray T.. Bolden S. and Wingo P.A. (1999) Cancer statistics, 1999. CA Cancer J Clin, 49, 8-31.

11. World Health Organization (1997) Health effects. In World Health Organization (ed.), Tobacco or Healih: a global status report. Vol. 1. World Health Organization, Geneva, pp. 43-48.

12. World Cancer Research Fund/Acadcmic Institute for Cancer Research (1997) Food, nutrition and the prevention of cancer: a global perspective. American Institute for Cancer Research, Washington D.C.

13. Pisani, P.. Parkin D.M., Bray F. and Ferlay J. (1999) Estimates of the worldwide mortality from 25 cancers in 1990. In J Cancer, 83, 18-29.

14. Ferlay, J., Parkin D.M. and Pisani P. (1998) GLOBOCAN. In International Agency for Research on Cancer. Cancer Basc (ed.). Cancer incidence and mortality worldwide (CD-rom). Vol. 3. International Agency for Research on Cancer, Lyon (France).

15. Wald, N.J. and Hackshaw A.K. (1996) Cigarette smoking: an cpidemiological overview. Br Med Bull. 52, 3-11.

16. Ingebrethsen, B.J. (1986) Aerosol studies of cigarctie smoke. Recem Adv Tobacco Sci, 12, 54-142.

17. Hoffmann. D. and Wynder E.L. (1986) Chemical constituents and bioactivity of tobacco smoke. In Zardize. D.G. and Peto, R. (eds), Tobacco: a major international health hazard. Vol. 74. International Agency for Research on Cancer, Lyon (France), pp. 145-165.

18. US Environmental Protection Agency (1992) Respiratory health effects of passive smoking: lung cancer and other disorders. US Environmental Protection Agency, Office of Healih and Environmental Assessment, Office of Research and Development, Washington D.C., EPA/600/6-90/006F.

19. Jaakkola. M.S. and Jaakkola J.J. (1997) Assessment of exposure to environmental tobacco smoke. Eur Respir $J, 10,2384-2397$.

20. National Research Council (1986) The physicochemical nature of sidestream smoke and environmental tobacco smoke. In Committee on Passive Smoking Board on Environmental Studies and Toxicology (ed.), Environmental tobacco smoke. Measuring exposure and assessing health effects. National Acadcmy Press, Washington D.C., pp. 25-53.

21. National Research Council (1986) Executive summary. In Committee on Passive Smoking Board on Environmental Studies and Toxicology (ed.). Environmental tobacco smoke. Measuring exposure and assessing health effects. National Academy Press, Washington D.C., pp. 1-12.

22. Hoffmann. D., Haley N.J., Adams J.D. and Brunnemann K.D. (1984) Tobacco sidestream smoke: uptake by nonsmokers. Prev Med, 13, 608-617.

23. International Agency for Research on Cancer (1994) Overall evaluations of carcinogenicity: An updating of IARC monographs volumes 1-60. In Monographs on the evaluation of the carcinogenic risk of chemicals 10 humans. International Agency for Rescarch on Cancer, Lyon (France).

24. Smith. C.J., Livingston S.D. and Doolittle D.J. (1997) An international literature survey of "IARC Group I carcinogens" reported in mainstream cigarette smoke. Food Chem Toxicol, 35, 1107-1130.

25. Hecht. S.S. (1996) Carcinogenesis due to tobacco: molecular mechanisms. In Bertino, J.R. (ed.). Encyclopedia of cancer. Academic Press. San Dicgo (CA), pp. 220-232.

26. Ross, J.A., Nelson G.B.. Wilson K.H., Rabinowitz J.R., Galati A., Stoner G.D., Nesnow S. and Mass M.J. (1995) Adenomas induced by polycyclic aromatic hydrocarbons in strain A/J mouse lung correlatc with timeintegrated DNA adduct levels. Cancer Res, 55, 1034-1044.

27. Hemminki, K. (1993) DNA adducts, mutations and cancer. Carcinogenesis, 14, 2007-2012.

28. Denissenko. M.F.. Pao A., Tang M. and Pfeifer G.P. (1996) Preferential formation of benzo[a]pyrene adducts at lung cancer mutational hotspots in P53. Science, 274. 430-432.

29. Nesnow, S., Ross J.A.. Stoner G.D. and Mass M.J. (1995) Mechanistic linkage between DNA adducts. mutations in oncogenes and tumorgenesis of carcinogenic environmental polycyclic aromatic hydrocarbons in strain $A / J$ mice. Toxicology, 105, 403-413. 
30. Williams, G.M., latropoulos M.J. and Weisburger J.H. (1996) Chemical carcinogen mechanisms of action and implications for testing methodology. Exp Toxicol Pathol, 48, 101-111.

31. Goldring, J. and Lucier G. (1990) Protein and DNA adducts. In Hulka. B.S., Wilcosky. T. and Griffith, J. (eds), Biological markers in epidemiology. Vol. I. Oxford University Press, New York, pp. 78-104.

32. Intcrnational Agency for Rescarch on Cancer (1986) Tobacco smoking. In Monographs on the evaluation of the carcinogenic risk of chemicals to humans. Vol. 38. International Agency for Research on Cancer, Lyon (France). pp. 37-375.

33. Guerin, M.R. (1978) Energy sources of polycyclic aromatic hydrocarbons. In Gelboin, H.V. and Ts'o, P.O.P. (cds). Polycyclic hydrocarbons and cancer. Vol. 1. Academic Press, New York, pp. 3-42.

34. Grimmer, G. (1983) Environmental carcinogens: polycyclic aromatic hydrocarbons. CRC Press, Boca Raton.

35. Hall. M. and Grover P.L. (1990) Polycyclic aromatic hydrocarbons: metabolism, activation and tumour initiation. In Cooper, C.S. and Grover. P.L. (eds), Chemical carcinogenesis and mulagenesis I. Vol. 94/1. Springer-Verlag. Berlin-Heidelberg, pp. 327-372.

36. Nebert. D.W. and Gonzalez F.J. (1987) P450 genes: structure, cvolution, and regulation. Annu Rev Biochem, 56. $945-993$.

37. Burchell. B., McGurk K.. Bricrley C.H. and Clarke D.J. (1997) UDP-glucuronosyltransferases. In Guengerich. F.P. (ed.). Comprehensive toxicology: biorransformation. Vol. 3. Elsevier Science, Oxford (UK), pp. 401-436.

38. Duffel, M.W. (1997) Sulfotransferases. In Guengerich, F.P. (ed.). Comprehensive toxicology: biotransformation. Vol. 3. Elsevier Science, Oxford (UK), pp. 365-384.

39. Guenther, T.M. and Oech F. (1981) Microsomal epoxide hydrolase and its role in polycyclic aromatic hydrocarbonstransformation. In Gclboin. H.V. and Ts'o, P.O.P. (eds), Polycyclic aromatic hydrocarbons and cancer. Vol. 3. Academic Press, New York. pp. 183-212.

40. Armsrong, R.N. (1997) Glutathione-S-transferases. In Guengerich. F.P. (ed.). Comprehensive 1oxicology: biotransformation. Vol. 3. Elsevier Science, Oxford (UK), pp. 307-327.

41. Hecht, S.S. (1999) Tobacco smoke carcinogens and lung cancer. I Natl Cancer Inst. 91, 1194-1210.

42. Fu. P.P. Harvey R.G. and Beland F.A. (1978) Molecular orbital theoretical prediction of the isomeric products formed from reactions of arene oxide and related metabolites of polycyclic aromatic hydrocarbons. Tetrahedron, 34, 857-866.

43. Thakker, D.R. (1985) Polycyclic aromatic hydrocarbons: metabolic activation to ultimate carcinogens. In Anders, M.W. (ed.), Bioactivation of foreign compounds. Academic Press, New York (NY), pp. 177-242.

44. Trager, W.F. and Jones J.P. (1987) Stereochemical considerations in drug metabolism. Prog Drug metab, 10 , 55-83.

45. Dipple, A., Moschel R.C. and Bigger C.A.H. (1984) Polynuclcar aromatic carcinogens. In Scarlc, C.E. (ed.), Chemical carcinogens. Vol. 1, 2nd ed. American Chemical Socicty, Washington D.C., pp. 41-163.

46. Weinstein, I.B., Jeffrey A.M., Jennette K.W.. Blobstein S.H., Harvey R.G., Harris C., Autrup H., Kasai H. and Nakanishi K. (1976) Benzola]pyrene diol epoxides as intermediates in nucleic acid binding in vitro and in vivo. Science, 193, 592-595.

47. Alloway, B.J. and Ayres D.C. (1994) Chemical principles of emvirommental pollution. Blackie Academic \& Professional, Glasgow (UK)

48. Kennaway. E. (1955) The identification of a carcinogenic compound in coal-tar. Bmj, 2, 749-752.

49. Poirier, M.C. and Weston A. (1996) Human DNA adduct measurements: state of the art. Environ Health Perspect. 104 Suppl 5. 883-893.

50. Phillips. D.H. (1996) DNA adducts in human tissues: biomarkers of exposure to carcinogens in tobacco smoke. Environ Heallh Perspect, 104 Suppl 3, 453-458.

51. Phillips. D.H., Hewer A., Martin C.N., Garner R.C. and King M.M. (1988) Correlation of DNA adduct levels in human lung with cigarctte smoking. Nature. 336, 790-792.

52. Geneste, O., Camus A.M., Castegnaro M., Petruzzelli S., Macchiarini P., Angelctti C.A., Giuntini C. and Bartsch H. (1991) Comparison of pulmonary DNA adduct levels, measured by "P- postlabelling and aryl hydrocarbon hydroxylase activity in lung parenchyma of smokers and ex-smokers. Carcinogenesis, 12, 13011305.

53. Van Schooten, F.J.. Hillebrand M.J., van Leeuwen F.E., Lutgerink J.T., van Zandwijk N., Jansen H.M. and Krick E. (1990) Polycyclic aromatic hydrocarbon-DNA adducts in lung tissue from lung cancer patients. Carcinogenesis, 11, 1677-1681.

54. Lewtas, J., Mumford J., Everson R.B., Hulka B., Wilcosky T., Kozumbo W., Thompson C., George M., Dobias L., Sram R. and et al. (1993) Comparison of DNA adducts from exposurc to complex mixtures in various human tissues and experimental systems. Environ Health Perspect, 99, 89-97.

55. Spencer-Beach. G.G. Beach A.C. and Gupta. R.C. (1996) High-resolution anion-exchange and partition thinlayer chromatography for complex mixtures of "P-postlabeled DNA adducts. $J$ Chromaiogr B Biomed Appl. $677,265-273$.

56. Weston, A. and Bowman E.D. (1991) Fluorescence detection of benzo[a]pyrene-DNA adducts in human lung. Carcinogenesis, 12, 1445-1449.

57. Gupta. R.C., Arif J.M. and Gairola C.G. (1999) Enhancement of pre-existing DNA adducts in rodents exposed to cigarette smoke. Mutat Res, 424, 195-205.

58. Hollstein, M.. Sidransky D., Vogelstein B. and Harris C.C. (1991) p53 mutations in human cancers. Science, 253, 49-53.

59. Smith, L.E.. Denissenko M.F., Bennet W.P., Li H., Amin S., Tang M. and Pfeifer G.P. (2000) Targeting of lung cancer mutational hotspots by polycyclic aromatic hydrocarbons. $J$ Nall Cancer Inst, 92, 803-811. 
60. Degawa, M., Stern S.J., Martin M.V., Guengerich F.P., Fu P.P., Ilett K.F., Kaderlik R.K. and Kadlubar F.F. (1994) Mctabolic activation and carcinogen-DNA adduct detection in human larynx. Cancer Res, 54, 49154919.

61. Szyffer. K., Hemminki K., Szyfter W.. Szmeja Z.. Banaszewski J. and Yang K. (1994) Aromatic DNA adducts in larynx biopsies and leukocytes. Carcinogenesis. 15, 2195-2199.

62. Hainaut. P., Hernandez T., Robinson A., Rodriguez-Tome P.. Flores T., Hollstein M., Harris C.C. and Montesano R. (1998) IARC Database of p53 gene mutations in human tumors and cell lines: updated compilation, revised formats and new visualisation tools. Nucleic Acids Res, 26, 205-213.

63. Zhang, L.F., Hemminki K., Szyfter K., Szyfter W. and Soderkvist P. (1994) p53 mutations in larynx cancer. Carcinogenesis, 15, 2949-2951.

64. Dunn, B.P. and Stich H.F. (1986) "2P-postlabelling analysis of aromatic DNA adducts in human oral mucosal cells. Carcinogenesis, 7, 1115-1120.

65. Chacko, M. and Gupta R.C. (1988) Evaluation of DNA damage in the oral mucosa of tobacco users and non-users by "'P-adduct assay. Carcinogenesis, 9, 2309-2313.

66. Jones, N.J.. McGregor A.D. and Waters R. (1993) Detection of DNA adducts in human oral tissue: correlation of adduct levels with tobacco smoking and differential enhancement of adducts using the butanol extraction and nuclease PI versions of "2P postlabeling. Cancer Res, 53, 1522-1528.

67. Stonc, J.G.. Jones N.J., McGregor A.D. and Waters R. (1995) Development of a human biomonitoring assay using buccal mucosa: comparison of smoking-related DNA adducts in mucosa versus biopsies. Cancer Res, 55. 1267.1270 .

68. Hsu, T.M.. Zliang Y.J. and Santella R.M. (1997) Immunoperoxidase quantitation of 4-aminobiphenyl- and polycyclic aromatic hydrocarbon-DNA adducts in exfoliated oral and urothelial cells of smokers and nonsmokers. Cancer Epidemiol Biomarkers Prev, 6, 193-199.

69. Romano, G., Sgambato A., Boninsegna A., Flamini G., Curigliano G.. Yang Q., La Gioia V., Signorelli C. Fcrro A., Capelli G., Santella R.M. and Cittadini A. (1999) Evaluation of polycyclic aromatic hydrocarbonDNA adducts in exfoliated orai cclls by an immunohistochemical assay. Cancer Epidemiol Biomarkers Prev, 8 , $91-96$.

70. Nia, A.B., Van Straaten H.W., Godschalk R.W., Van Zandwijk N.. Balm A.J., KIcinjans J.C. and Van Schooten F.J. (2000) Immunoperoxidase detection of polycyclic aromatic hydrocarbon-DNA adducts in mouth floor and buccal mucosa cells of smokers and nonsmokers. Environ Mol Mutagen, 36. 127-133.

71. Zhao, C.. Georgellis A., Flato S., Palmberg L.. Thunberg E. and Hemminki K. (1997) DNA adducts in human nasal mucosa and white blood cells from smokers and non-smokers. Carcinogenesis, 18. 2205-2208.

72. Peluso. M.. Amasio E., Bonassi S., Munnia A., Altrupa F. and Parodi S. (1997) Detection of DNA adducts in human nasal mucosa tissuc by "2p-postlabeling analysis. Carcinogenesis, 18, 339-344.

73. Simons. A.M.. Phillips D.H. and Coleman D.V. (1993) Damage to DNA in cervical epithelium related to smoking tobacco. Bmj, 306, 1444-1448.

74. Simons. A.M., Mugica van Herckenrode C., Rodriguez J.A., Maitland N., Anderson M., Phillips D.H. and Coleman D.V. (1995) Demonstration of smoking-related DNA damage in cervical epithelium and correlation with human papillomavirus type 16, using exfoliated cervical cells. Br J Cancer, 71, 246-249.

75. Mancini, R., Romano G., Sgambato A., Flamini G., Giovagnoli M.R., Boninsegna A., Carraro C., Vecchione A. and Cittadini A. (1999) Polycyclic aromatic hydrocarbon-DNA adducts in cervical smears of smokers and nonsmokers. Gynecol Oncol. 75, 68-71.

76. Arnould, J.P., Verhoest P.. Bach V., Libert J.P. and Belegaud J. (1997) Detcction of benzola]pyrene-DNA adducts in human placenta and umbilical cord blood. Htum Exp Toxicol, 16, 716-721.

77. Hansen, C., Sorensen L.D.. Asmussen I. and Autrup H. (1992) Transplacental exposure to tobacco smoke in human-adduct formation in placenta and umbilical cord blood vessels. Teratog Carcinog Mutagen, 12. 51-60.

78. Everson, R.B., Randerath E., Santella R.M., Avitts T.A.. Weinstein I.B. and Randerath K. (1988) Quantitative associations between DNA damage in human placenta and maternal smoking and birth weight. $J$ Natl Cancer Inst, 80, 567-576.

79. Gallagher, J.E., Vine M.F., Schramm M.M., Lewtas J., George M.H., Hulka B.S. and Everson R.B. (1993) "3P. postlabeling analysis of DNA adducts in human sperm cells from smokers and nonsmokers. Cancer Epidemiol Biomarkers Prev, 2, 581-585.

80. Little. J. and Vainio H. (1994) Mutagenic lifestyles? A review of evidence of associations between germ-cell mutations in humans and smoking, alcohol consumption and use of 'recreational' drugs. Mutat Res, 313, 131151 .

81. Zenzes. M.T., Puy L.A., Bielecki R. and Reed T.E. (1999) Detection of benzo[a]pyrene diol epoxide-DNA adducts in embryos from smoking couples: cvidence for transmission by spermatozoa. Mol Hum Reprod, 5 , |25-131.

82. Zenzes, M.T., Bielecki R. and Reed T.E. (1999) Detection of benzo[a]pyrene diol epoxide-DNA adducts in sperm of men exposed to cigarette smoke. Fertil Steril, 72. 330-335.

83. Perera. F.P.. Estabrook A.. Hewer A.. Channing K., Rundle A., Mooney L.A., Whyatt R. and Phillips D.H. (1995) Carcinogen-DNA adducts in human breast tissue. Cancer Epidemiol Biomarkers Prev, 4, 233-238.

84. Li. D.. Wang M.. Dhingra K. and Hittelman W.N. (1996) Aromatic DNA adducts in adjacent tissues of breast cancer patients: clues to breast cancer etiology. Cancer Res, 56, 287-293.

85. Rundle, A., Tang D., Hibshoosh H., Estabrook A., Schnabel F., Cao W., Grumet S. and Perera F.P. (2000) The relationship between genetic damage from polycyclic aromatic hydrocarbons in breast tissuc and breast cancer. Carcinogenesis, 21, $1281-1289$. 
86. Dyke, G.W., Craven J.L., Hall R. and Garner R.C. (1992) Smoking-related DNA adducts in human gastric cancers. Int $J$ Cancer, 52, 847-850.

87. Zhang. Y.J., Li Y.. DeLeo V.A. and Santella R.M. (1990) Detection of DNA adducts in skin biopsies of coal tartreated psoriasis patients: immunofluorescence and "P postlabeling. Skin Pharmacol, 3, 171-179.

88. Godschalk, R.W., Ostertag J.U., Moonen E.J., Neumann H.A., Klcinjans J.C. and van Schooten F.J. (1998) Aromatic DNA adducts in human white blood cells and skin after dermal application of coal tar. Cancer Epidemiol Biomarkers Prev, 7, 767-773.

89. Van Schooten, F.J., Hillebrand M.J., van Lecuwen F.E., van Zandwijk N., Jansen H.M., den Engelse L. and Kriek E. (1992) Polycyclic aromatic hydrocarbon-DNA adducts in white blood cells from lung cancer patients: no correlation with adduct levels in lung. Carcinogenesis, 13, 987-993.

90. Reddy, M. V.. and Blackburn, G. R. ${ }^{32} \mathrm{P}$-assay of DNA adducts in white blood cells and placentas of pregnant women: lack of residential wood combustion-related adducts but presence of tissue-specific endogenous adducts. Teratog Carcinog Mutagen, 10: 373-384, 1990.

91. Rothman. N., Poirier M.C. Baser M.E.. Hansen J.A., Gentile C., Bowman E.D. and Strickland P.T. (1990) Formation of polycyclic aromatic hydrocarbon-DNA adducts in peripheral white blood cells during consumption of charcoal-broiled beef. Carcinogenesis, 11. 1241-1243.

92. Boggs, D.R. and Winkelstein A. (1983) White Cells Manual. F. A. Davis, Philadelphia.

93. Savela, K. and Hemminki K. (1991) DNA adducts in lymphocytes and granulocytes of smokers and nonsmokers detected by the "P-postlabelling assay. Carcinogenesis, 12, 503-508.

94. Hol\%, O.. Krause T. and Rudiger H.W. (1991) Differences in DNA adduct formation between monocytes and lymphocyles after in vivo incubation with benzo[a]pyrenc. Carcinogenesis, 12, 2181-2183.

95. Van Schooten, F.J., Godschalk R.W., Brecdijk A.. Maas L.M., Kriek E., Sakai H., Wigbout G., Baas P.. Van't Veer L. and Van Zandwijk N. (1997) "2P.postlabelling of aromatic DNA adducts in white blood cells and alveolar macrophages of smokers: saturation at high exposures. Mutat Res, 378, 65-75.

96. Izzoti, A., Rossi G.A., Bagnasco M. and De Flora S. (1991) Benzo[a]pyrene diolepoxide-DNA adducts in alveolar macrophages of smokers. Carcinogenesis, 12, $1281-1285$.

97. De Flora, S., Izzotti A., D'Agostini F., Rossi G.A. and Balansky R.M. (1993) Pulmonary alveolar macrophages in molecular epidemiology and chemoprevention of cancer. Environ Health Perspect, 99, 249-252.

98. Harris, C., Hsu I., Stoner G., Trump B. and Selkirk J. (1978) Human pulmonary alveolar macrophages metabolise benzo[a]pyrenc to proximate and ultimate mutagens. Nature, 272, 633-634.

99. Petruzzelli, S., Bernard P., Paoletti P., Rane A., Giuntini C. and Pacifici G. (1988) Presence of epoxide hydrolase and glutathione $S$-transferase in human pulmonary alveolar macrophages. Eur $J$ Clin Pharmacol. 34 , $419-421$.

100. Nelson, D.R., Koymans L., Kamataki T.. Stegeman J.J., Feycreisen R., Waxman D.J., Waterman M.R., Gotoh O., Coon M.J., Estabrook R.W., Gunsalus I.C. and Nebert D.W. (1996) P450 superfamily: update on new sequences, gene mapping, accession numbers and nomenclature. Pharmacogenetics, 6, 1-42.

101. Zhang, Z.Y., Fasco M.J., Huang L., Guengerich F.P. and Kaminsky L.S. (1996) Characicrization of purified luman recombinant cytochrome P450/AI- /le462 and-Val462: assessment of a role for the rare allele in carcinogcnesis. Cancer Res, 56, 3926-3933.

102. Cosma. G.. Crotis F.. Taioli E.. Toniolo P. and Garte S. (1993) Relationship between genotype and function of the human CYPIAI gene. J Toxicol Environ Health, 40, 309-316.

103. Hayashi, S., Watanabe J., Nakachi K. and Kawajiri K. (199!) Genetic linkage of lung cancer-associated Msp! polymorphisms with amino acid replacement in the heme binding region of the human cytochrome P450IAI gene. J Biochem (Tokyo), 110, 407-411.

104. Crofts, F., Taioli E., Trachman J., Cosma G.N., Currie D., Toniolo P. and Garte S.J. (1994) Functional significance of different human CYPIAI genotypes. Carcinogenesis, 15, 2961-2963.

105. Kawajiri, K.. Eguchi H., Nakachi K.. Sekiya T. and Yamamoto M. (1996) Association of CYPJAI germ line polymorphisms with mutations of the $p 53$ gene in lung cancer. Cancer Res, 56, 72-76.

106. Park, J.Y.. Muscat J.E., Ren Q., Schaniz S.P., Harwick R.D., Stern J.C., Pike V., Richie J.P.Jr. and Lazarus P. (1997) CYPIAI and GSTMI polymorphisms and oral cancer risk. Cancer Epidemiol Biomarkers Prev, 6, 791797.

107. Rothman. N., Shiclds P.G., Poiricr M.C., Harrington A.M.. Ford D.P. and Strickland P.T. (1995) The impact of glutathione $S$-transferase $\mathrm{M} I$ and cytochrome $P 450 \mathrm{IA} /$ genotypes on white-blood-cell polycyclic aromatic hydrocarbon-DNA adduct levels in humans. Mol Carcinog, 14, 63-68.

108. Ichiba, M., Hagmar L.. Rannug A., Hogsiedt B., Alexandrie A.K.. Carstensen U. and Hemminki K. (1994) Aromatic DNA adducts, micronuclei and genetic polymorphism for CYPIAI and GSTI in chimney swceps. Carcinogenesis, 15, 1347-1352.

109. Mannervik, B. and Danielson U.H. (1988) Glutathione transferases-structure and catalytic activity. CRC Crit Rev Biochem, 23, 283-337.

110. Hayes, J.D. and Pulford D.J. (1995) The glutathione S-iransferase supergene family: regulation of GST and the contribution of the isoenzymes to cancer chemoprotection and drug resistance. Crit Rev Biochem Mol Biol. 30, $445-600$.

111. Seidegård, J., Vorachek W.R., Pero R.W. and Pearson W.R. (1988) Hereditary differences in the expression of the human glutathione transferase active on trans-stilbenc oxide are due to a gene deletion. Proc Nall Acad Sci $U$ $S$ A. 85, 7293-7297.

112. McWilliams, J.E., Sanderson B.J.. Harris E.L.. Richert-Boc K.E. and Henner W.D. (1995) Glutathione $S$ transferase MI (GSTMI) deficiency and lung cancer risk. Cancer Epidemiol Biomarkers Prev, 4, 589-594. 
113. Bell, D.A., Taylor J.A., Paulson D.F., Robertson C.N., Mohler J.L. and Lucier G.W. (1993) Genetic risk and carcinogen exposure: a common inherited defect of the carcinogen-metabolism gene glutathione $S$-transferase MI (GSTMI) that increases susceptibility to bladder cancer. J Natl Cancer Inst, 85, $1159-1164$.

114. Heagerty, A.H., Fitzgerald D., Sinith A., Bowers B., Jones P., Fryer A.A., Zhao L., Alldersea J. and Strange R.C. (1994) Glutathione $S$-transferase GSTMl phenotypes and protection against cutaneous tumours. Lancel, 343 , 266-268.

115. Nazar-Stewart. V., Vaughan T.L., Burt R.D., Chen C., Berwick M. and Swanson G.M. (1999) Glutathione Stransferase M1 and susceptibility to nasopharyngeal carcinoma. Cancer Epidemiol Biomarkers Prev, 8, 547551.

116. Kato. S., Bowman E.D., Harrington A.M., Blomeke B. and Shields P.G. (1995) Human lung carcinogen-DNA adduct levels mediated by genetic polymorphisms in vivo. J Natl Cancer Inst, 87, 902-907.

117. Bartsch, H., Rojas M., Nair U., Nair J. and Alexandrov K. (1999) Genetic cancer susceptibility and DNA adducts: studies in smokers, tobacco chewers, and coke oven workers. Cancer Detect Prev, 23, 445.453.

118. Jourenkova, N., Reinikainen M., Bouchardy C., Dayer P., Benhamou S. and Hirvonen A. (1998) Larynx cancer risk in relation to glutathione $S$-transferase $\mathrm{M} 1$ and $\mathrm{Tl}$ genotypes and tobacco smoking. Cancer Epidemiol Biomarkers Prev, 7, 19-23.

119. Shiclds, P.G., Bowman E.D., Harrington A.M., Doan V.T. and Weston A. (1993) Polycyclic aromatic hydrocarbon-DNA adducts in human lung and cancer susceptibility genes. Cancer Res, 53, 3486-3492.

120. Ryberg, D., Skaug V., Hewer A., Phillips D.H., Harries L.W., Wolf C.R., Ogreid D., Ulvik A., Vu P. and Haugen A. (1997) Genotypes of glutathione transferase $M 1$ and P1 and their significance for lung DNA adduct levels and cancer risk. Carcinogenesis, $18,1285-1289$.

121. Rojas, M., Cascorbi I., Alexandrov K., Krick E., Auburtin G., Mayer L.. Kopp-Schneider A., Roots I. and Bartsch H. (2000) Modulation of benzo[a]pyrene diolepoxide-DNA adduct levels in human white blood cells by CYPIAI, GSTMI and GSTTI polymorphism. Carcinogenesis, 21, 35-41.

122. Butkicwicz, D., Grzybowska E., Hemminki K., Ovrcbo S., Haugen A., Motykiewicz G. and Chorazy M. (1998) Modulation of DNA adduct levels in human mononuclear white blood cells and granulocytes by $C Y P I A l$, CYP2D6 and GSTMI genetic polymorphisms. Mutat Res, 415, 97-108.

123. Zimniak. P.. Nanduri B.. Pikula S., Bandorowicz-Pikula J., Singhal S.S., Srivastava S.K.. Awasthi S. and Awasthi Y.C. (1994) Naturally occurring human glutathione S-transferase GSTPI-I isoforms with isoleucine and valine in position 104 differ in cnzymic properties. Eur J Biochem, 224, 893-899.

124. Butkiewicz, D., Grzybowska E., Phillips D.H., Hemminki K. and Chorazy M. (2000) Polymorphisms of the GSTPI and GSTM/ genes and PAH-DNA adducts in human mononuclear white blood cells. Environ Mol Mutagen, 35, 99-105.

125. Hu, X., O'Donnell R., Srivastava S.K., Xia H., Zimniak P., Nanduri B., Bleicher R.J., Awasthi S., Awasthi Y.C., Ji X. and Singh S.V. (1997) Active site architeclure of polymorphic forms of human glutathione $S$ - transferase PI-I accounts for their enantioselectivity and disparate activity in the glutathione conjugation of 7beta,8alphadihydroxy-9alpha, 10alpha-oxy-7,8.9,10-tetrahydrobenzo[alpyrene. Biochem Biophys Res Commun, 235, 424-428.

126. Harries, L.W., Stubbins M.J., Forman D., Howard G.C. and Wolf C.R. (1997) Identification of genetic polymorphisms at the glutathione $S$ - transferase $\mathrm{Pi}$ locus and association with susceptibility to bladder, testicular and prostate cancer. Carcinogenesis, 18,641-644.

127. Helzlsouer, K.J., Selmin O., Huang H.Y., Strickland P.T., Hoffman S., Alberg A.J., Watson M., Comstock G.W. and Bell D. (1998) Association between glutathione S-Iransferase $\mathrm{Ml}, \mathrm{Pl}$, and $\mathrm{Tl}$ genetic polymorphisms and development of breast cancer. $J$ Natl Cancer Inst, 90, 512-518.

128. Katoh, T., Kaneko S., Takasawa S., Nagata N., Inatomi H., Ikemura K., Itoh H., Matsumoto T., Kawamoto T. and Bell D.A. (1999) Human glutathione $S$-transferase PI polymorphism and susceptibility to smoking related epithelial cancer; oral, lung, gastric, colorectal and urothelial cancer. Pharmacogenetics, 9, 165-169.

129. Butkiewicz, D., Cole K.J., Phillips D.H., Harris C.C. and Chorazy M. (1999) GSTMI, GSTPI, CYPIAI and CYP2D6 polymorphisms in lung cancer patients from an environmentally polluted region of Poland: correlation with lung DNA adduct levels. Eur J Cancer Prev. 8, 315-323.

130. Bartsch, H. (1996) DNA adducts in human carcinogenesis: etiological reievance and structure-activity relationship. Mural Res, 340, 67-79.

131. Kihara. M.. Kubota A., Furukawa M. and Kimura H. (1997) GSTMI gene polymorphism as a possible marker for susceptibility to head and neck cancers among Japanese smokers. Cancer Lett, 112, 257-262.

132. Patrianakos, C. and Hoffman D. (1979) Chemical studies on tobacco smoke LXIV. On the analysis of aromatic amines in cigarette smoke. J Anal Chem, 3, 150-154.

133. Beland, F.A. and Kadlubar F.F. (1990) Metabolic activation and DNA adducts of aromatic amines and nitroaromatic hydrocarbons. In Cooper. C.S. and Grover, P.L. (eds), Chemical carcinogenesis and mutagenesis I. Vol. 94/l. Springer-Verlag, Berlin-Heidelberg, pp. 297-325.

134. Vineis, P. and Pirastu R. (1997) Aromatic amines and cancer. Cancer Causes Control, 8, 346-355.

135. Stcineck. G., Plato N., Norell S.E. and Hogstedi C. (1990) Urothelial cancer and some industry-related chemicals: an cvaluation of the epidemiologic literature. Am J Ind Med, 17, 371-391.

136. Beland, F.A. and Kadlubar F.F. (1986) Factors involved in the induction of bladder cancer by aromatic amines. Banbury Rep. 23, 315-326.

137. MeMahon, R.E., Turner J.C. and Whitaker G.W. (1980) The $N$-hydroxylation and ring-hydroxylation of 4aminobiphenyl in vitro by hepatic mono-oxygenases from rat. mouse. hamster, rabbit and guinea-pig. Xenobiotica, 10, 469-481. 
138. Ziegler, D.M.. Ansher S.S.. Nagata T., Kadlubar F.F. and Jakoby W.B. (1988) $N$-methylation: potential mechanism for metabolic activation of carcinogenic primary arylamines. Proc Natl Acad Sci US A, 85, 25142517.

139. Kadlubar, F.F., Butler M.A., Hayes B.E., Beland F.A. and Guengerich F.P. (1988) Role of microsomal cytochromes $P .450$ and prostaglandin $H$ synthase in 4-aminobiphenyl-DNA adduct formation. In Miners, $J$., Birkett, D.J., Drew, R. and McManus, M. (eds), Microsomes and drig oxidations. Taylor and Francis, London, pp. $370-379$.

140. Kadlubar, F.F., Butler M.A., Culp S.J., Teitel C.H., Fu P.P., Shaikh A.U., Delcos K.B. and Beland F.A. (1989) Metabolic activation of arylamine derivatives of carcinogenic polycyclic nitroaromatic hydrocarbons. In Kato, R., Estabrook, R.W. and Cayen, M.N. (eds), Xenobiotic metabolism and deposition. Taylor and Francis, London, pp. 375-381.

141. Bryant. M.S., Skipper P.L., Tannenbaum S.R. and Maclure M. (1987) Hemoglobin adducts of 4-aminobipheny! in smokers and nonsmokers. Cancer Res, 47, 602-608.

142. Bryant, M.S., Vineis P., Skipper P.L. and Tannenbaum S.R. (1988) Hemoglobin adducts of aromatic amines: associations with smoking status and typc of tobacco. Proc Natl Acad Sci U S A, 85, 9788-9791.

143. Poupko, J.M., Hearn W.L. and Radomski J.L. (1979) N-Glucuronidation of $N$-hydroxy aromatic amines: a mechanism for their transport and bladder-specific carcinogenicity. Toxicol Appl Pharmacol, 50, 479-484.

144. Kadlubar, F.F., Beland F.A., Beranek D.T., Doolcy K.L., Heflich R.H. and Evans F.E. (1982) Arylamine-DNA adduct formation in relation to urinary bladder carcinogenesis and Salmonella typhimurium mutagenesis. In Sugimura, T. Kondo, S. and Takebe, H. (eds), Environmental muagens and carcinogens. Liss, New York, pp. 385-396.

145. Rehn. L. (1895) Blasengeschwülste bei Fuchsin-Arbeitern. Arch Klin Chir, 50, 588-600. Reprinted in translation: Shimkin MB (1980) Some classics of experimental oncology: 50 selections, 1775-1965. NIH publication no. $80-2150,44-51$.

146. Lcichtenstern, $O$. (1898) Uber Harnblasenentzündung und Harnblasengeschwülste bei Arbeitern in Farbfabriken. Deut Med Wochenschr, 24, 709-713.

147. Parkes, H.G. and Evans A.E.J. (1984) Epidemiology of aromatic amine cancers. In Scarle, C.E. (ed.), Chemical carcinogens. Vol 1. American Chemical Socicty. Washington D.C., pp. 277-30I (ACS Monograph 182).

148. Huepper, W.C., Wiely F.H., Wolfe H.D., Ranta K.E., Leming M.F. and Blood F.R. (1938) Experimental production of bladder tumors in dogs by administration of $b$-naphthylamine. $J$ Ind Hyg Toxicol, 20, 46-84.

149. Spitz, S., Maguigan W.H. and Dobriner K. (1950) The carcinogenic action of benzidine. Cancer, 3, 789-804.

150. Walpolc. A.L.. Williams M.H.C. and Roberts D.C. (1954) Tumours of the urinary bladder in dogs after ingestion of 4-aminodiphenyl. Br J Indust Med, 11, 105-109.

151. International Agency for Research on Cancer (1974) Some aromatic amines, hydrazine and related substances. $N$-nitroso compounds and miscellaneous alkylating agents. 2-Naphthylamine. In Monographs on the evaluation of the carcinogenic risk of chemicals to man. Vol. 4. World Health Organization, Lyon (France), pp. 97-111.

152. Doll, R., Vessey M.P., Beasley R.W.R., Fear E.C., Fisher R.E.W., Gammon E.T., Gunn W., Hughes G.O., Lee K. and Norman-Smith B. (1972) Mortality of gasworkers-final report of a prospective study. Br J Indust Med, 29. 394-406.

153. Patrianakos, C. and Hoffmann D. (1979) Chemical studies of tobacco smoke LXIV. On the analysis of aromatic amines in cigarette smoke. $J$ Anall Chem, 3, 150-154.

154. Vineis, P., Esteve J. and Terracini B. (1984) Bladder cancer and smoking in males: types of cigarettes, age at start, effect of stopping and interaction with occupation. Int J Cancer, 34, 165-170.

155. Hartge, P., Silverman D., Hoover R., Schairer C., Altman R., Austin D., Cantor K., Child M., Key C., Marrett L.D. and et al. (1987) Changing cigarette habits and bladder cancer risk: a case-control study. J Natl Cancer Inst. 78, $1119-1125$.

156. Morrison. A.S., Buring J.E., Verhock W.G., Aoki K., Leck I., Ohno Y. and Obata K. (1984) An international study of smoking and bladder cancer. $J$ Urol, 131, 650-654.

157. Vineis, P., Esteve J., Hartge P., Hoover R., Silverman D.T. and Terracini B. (1988) Effects of timing and type of tobacco in cigarette-induced bladder cancer. Cancer Res, 48, 3849-3852.

158. Clavel, J., Cordier S., Boccon-Gibod L. and Hemon D. (1989) Tobacco and bladder cancer in males: increased risk for inhalers and smokers of black tobacco. Int $J$ Cancer, 44, 605-610.

159. De Stefani, E., Barrios E. and Fierro L. (1993) Black (air-cured) and blond (flue-curcd) tobacco and cancer risk. III: Ocsophageal cancer. Eur J Cancer, 5, 763-766.

160. Malaveille, C., Vineis P., Esteve J., Ohshima H., Brun G., Hautefeuille A., Gallet P., Ronco G., Terracini B. and Bartsch H. (1989) Levels of mutagens in the urine of smokers of black and blond tobacco correlate with their risk of bladder cancer. Carcinogenesis, 10, 577-586.

161. Talaska, G.. al-Juburi A.Z. and Kadlubar F.F. (1991) Smoking related carcinogen-DNA adducts in biopsy samples of human urinary bladder: identification of $N$-(deoxyguanosin-8-yl)-4-aminobiphenyl as a major adduct. Proc Natl Acad Sci U S A, 88, 5350-5354.

162. Del Santo. P., Moneti G., Salvadori M.. Saltulti C., Delle Rose A. and Dolara P. (1991) Levels of the adducts of 4-aminobiphenyl to hemoglobin in control subjects and bladder carcinoma patients. Cancer Lett, 60, 245-251.

163. Hammond, S.K., Coghlin J.. Gann P.H., Paul M., Taghizadeh K., Skipper P.L. and Tannenbaum S.R. (1993) Relationship between environmental tobacco smoke exposure and carcinogen-hemoglobin adduct levels in nonsmokers. J Natl Cancer Inst, 85, 474-478. 
164. Talaska, G., Schamer M., Skipper P., Tannenbaum S., Caporaso N., Unruh L., Kadlubar F.F., Bartsch H., Malaveille C. and Vineis P. (1991) Detection of carcinogen-DNA adducts in exfoliated urothelial cells of cigarette smokers: association with smoking, hemoglobin adducts, and urinary mutagenicity. Cancer Epidemiol Biomarkers Prev, 1, 61-66.

165. Romano, G., Mancini R., Fedele P., Curigliano G., Flamini G., Giovagnoli M.R., Malara N., Boninsegna A., Vecchione A., Santella R.M. and Cittadini A. (1997) Immunohistochemical analysis of 4-aminobiphenyl-DNA adducts in oral mucosal cells of smokers and nonsmokers. Amicancer Res, 17, 2827-2830.

166. Curigliano, G., Zhang Y.J., Wang L.Y., Flamini G., Alcini A., Ratto C., Giustacchini M., Alcini E., Cittadini A. and Santella R.M. (1996) Immunohistochemical quantitation of 4-aminobiphenyl-DNA adducts and p53 nuclear overexpression in T1 bladder cancer of smokers and nonsmokers. Carcinogenesis, 17, 911-916.

167. Minchin, R.F., Reeves P.T., Teitel C.H., McManus M.E., Mojarrabi B., Ilell K.F. and Kadlubar F.F. (1992) Nand $O$-acetylation of aromatic and heterocyclic amine carcinogens by human monomorphic and polymorphic acetyltransferases expressed in COS-I cells. Biochem Biophys Res Commun, 185, 839-844.

168. Kirlin, W.G., Trinidad A., Yerokun T., Ogolla F., Ferguson R.J., Andrews A.F., Brady P.K. and Hein D.W. (1989) Polymorphic expression of acctyl cocnzyme A-dependent arylamine $N$-acetyltransferase and acetyl coenzyme $A$-dependent $O$-acetyltransferase-mediated activation of $N$-hydroxyarylamines by human bladder cylosol. Cancer Res. 49. 2448-2454.

169. Frederickson, S.M., Messing E.M., Reznikoff C.A. and Swaminathan S. (1994) Relationship between in vivo acetylator phenotypes and cytosolic $N$-acetyltransferase and $O$-acetyltransferase activities in human uroepithelial cells. Cancer Epidemiol Biomarkers Prev. 3, 25-32.

170. Weber. W.W. and Vatsis K.P. (1993) Individual variability in $p$-aminobenzoic acid $N$-acetylation by human $N$ acetyliransferase (NATI) of peripheral blood. Pharmacogenetics, 3, 209-212.

171. Bell, D.A.. Badawi A.F., Lang N.P.. llett K.F.. Kadlubar F.F. and Hirvonen A. (1995) Polymorphism in the Nacetyltransferase I (NATI) polyadenylation signal: association of $N A T / * 10$ allcle with higher $N$-acetylation activity in bladder and colon tissue. Cancer Res. 55. 5226-5229.

172. Woillieb, J.C., Hunter C.F., Blass B., Kadlubar F.F., Chu D.Z. and Lang N.P. (1990) Aromatic amine acctyltransferase as a marker for colorectal cancer: environmental and demographic associations. Int $J$ Cancer. 46, $22-30$.

173. Blum, M., Demicrre A.. Grant D.M.. Hein M. and Meyer U.A. (1991) Molecular mechanism of slow acetylation of drugs and carcinogens in humans. Proc Natl Acad Sci U S A, 88, 5237-5241.

174. Bell, D.A.. Taylor J.A.. Butler M.A., Stephens E.A., Wiest J., Brubaker L.H., Kadlubar F.F. and Lucier G.W. (1993) Genotype/phenotype discordance for human arylamine $N$-acetyltransferase (NAT2) reveals a new slowacetylator altele common in African-Americans. Carcinogenesis, 14, 1689-1692.

175. Lin, H.J., Han C.Y., Lin B.K. and Hardy S. (1994) Ethnic distribution of slow acetylator mutations in the polymorphic $N$-acetyltransferase (NAT2) gene. Pharmacogenetics, 4, 125-134.

176. Kadlubar, F.F. and Hammons G.J. (1987) The role of cytochrome $P-450$ in metabolism of chemical carcinogens. In Guengerich, F.P. (ed.), Mammalian cytochromes P-450. Vol. 2. CRC Press, Boca Raton, Florida, pp. 81 130.

177. Butler, M.A., Iwasaki M., Guengerich F.P. and Kadlubar F.F. (1990) Human cytochrome P-450 $(P .4501 A 2)$, the phenacetin $O$-decthylase, is primarily responsible for the hepatic 3-demethylation of coffeine and $N$ oxidation of carcinogenic arylamines. Proc Nall Acad Sci U S A, 86, 7696-7700.

178. Bartsch. H., Malaveille C.. Friesen M.. Kadlubar F.F. and Vineis P. (1993) Black (air-cured) and blond (fluecured) tobacco cancer risk. IV: Molecular dosimetry studies implicate aromatic amincs as bladder carcinogens. Eur J Cancer, 8, 1199-1207.

179. Landi. M.T., Zocchetti C., Bernucci 1., Kadlubar F.F., Tannenbaum S., Skipper P., Bartsch H., Malaveille C. Shields P., Caporaso N.E. and Vineis P. (1996) Cytochrome P450IA2: enzyme induction and genetic control in determining 4-aminobipheny!-hemoglobin adduct levels. Cancer Epidemiol Biomarkers Prev, 5, 693-698.

180. Brockmoller, J., Kaiser R., Kerb R., Cascorbi I., Jaeger V. and Roots I. (1996) Polymorphic enzymes of xenobiotic metabolism as modulators of acquired P53 mutations in bladder cancer. Pharmacogenetics. 6, 535 545.

181. Thygesen, P., Risch A., Stacey M., Giannoulis F., Takle L., Knowles M. and Sim E. (1999) Genes for human arylamine $N$-acetyltransferases in relation to loss of the short arm of chromosome 8 in bladder cancer. Pharmacogenetics, 9, 1-8.

182. Stacey. M.. Matas N.. Drake M.. Payton M.. Fakis G., Greenland J. and Sim E. (1999) Arylamine $N$ acetyltransferase type 2 (NAT2), chromosome 8 aneuploidy, and identification of a novel NATI cosmid clone: an investigation in bladder cancer by interphase FISH. Genes Chromosomes Cancer, 25, 376-383.

183. Church, D.F. and Pryor W.A. (1985) Free-radical chemistry of cigarette smoke and its toxicological implications. Environ Health Perspect, 64, 111-126.

184. Ames, B.N. (1989) Endogenous DNA damage as related to cancer and aging. Mutat Res, 214, 41-46.

185. Pryor, W.A.. Prier D.G. and Church D.F. (1983) Electron-spin resonance study of mainstream and sidestream cigarette smoke: nature of the free radicals in gas-phase smoke and in cigaretic tar. Environ Health Perspect, 47, 345-355.

186. Halliwel, B. and Aruoma O. (1993) DNA and free radicals. Horwood, London.

187. Dizdaroglu, M. (1991) Chemical determination of free radical-induced damage to DNA. Free Radic Biol Med, 10 , 225-242.

188. Ahnström, G. (1988) Techniques to measure DNA single-strand breaks in cells: a review. Imt J Radiat Biol, 54 , 695-707. 
189. Beesk. F., Dizdaroglu M., Schulte-Frohlinde D. and von Sonntag C. (1979) Radiation-induced DNA strand breaks in deoxygenated aqueous solutions. The formation of altered sugars as end groups. Int $J$ Radiat Biol Relat Stud Phys Chem Med, 36, 565-576.

190. Ames, B.N. and Gold L.S. (1991) Endogenous mutagens and the causes of aging and cancer. Murat Res, $250,3-$ 16.

191. Seis, H. (1991) Oxidants and antioxidants. In Scis, H. (ed.), Oxidative stress. Academic Press, New York.

192. Steenken, S. (1989) Structure, acid/base properties and transformation reactions of purine radicals. Free Radic Res Commun, 6. 117-120.

193. Dizdaroglu. M. (1986) Free-radical-induced formation of an 8.5'-cyclo-2'-deoxyguanosine moiety in deoxyribonucleic acid. Biochem J, 238, 247-254.

194. Nakac. D., Kobayashi Y., Akai H., Andoh N., Satoh H., Ohashi K., Tsutsumi M. and Konishi Y. (1997) Involvement of 8 -hydroxyguanine formation in the initiation of rat liver carcinogenesis by low dose levels of $N$-nitrosodicthylamine. Cancer Res, 57, 1281-1287.

195. Cheng, K.C., Cahill D.S., Kasai H. Nishimura S. and Locb L.A. (1992) 8-Hydroxyguanine, an abundant form of oxidative DNA damagc, causes $G \rightarrow T$ and $A \rightarrow C$ substitutions. J Biol Chem, 267, 166-172.

196. Halliwell, B. and Aruoma O.I. (1991) DNA damage by oxygen-derived species. Its mechanism and measurement in mammalian systems. FEBS Lett, 281, 9.19.

197. Demple, B. and Harrison L. (1994) Repair of oxidative damage to DNA: enzymology and biology. Annu Rev Biochem, 63, 915-948.

198. Yu, Z.. Chen J., Ford B.N., Brackley M.E. and Glickman B.W. (1999) Human DNA repair systems: an overview. Environ Mol Mulagen, 33, 3-20.

199. Boiteux, S. (1990) Substrate specificity of the formamidopyrimidine-DNA glycosylase of $E$. coli: repair of the imidazole ring-opened form of $N$-hydroxy-2-amino-fluorene-guanine adducts in DNA. In Lambert, M.W. and Laval, J. (eds). DNA repair mechanisms and their biological implications in mammalian cells. Plenum, New York, pp. 37-44.

200. Aburatani. H., Hippo Y.. Ishida T., Takashima R., Matsuba C., Kodama T., Takao M., Yasui A., Yamamoto K. and Asano M. (1997) Cloning and characierization of mammalian 8-hydroxyguanine-specific DNA glycosylase/apurinic. apyrimidinic lyase, a functional muM homologue. Cancer Res, 57, 2151-2156.

201. Mee, L.K. and Adelstein S.J. (1981) Predominance of core histones in formation of DNA-protein crosslinks in gamma-irradiated chromatin. Proc Natl Acad Sci U S A, 78, 2194-2198.

202. Margolis, S.A., Coxon B., Gajewski E. and Dizdaroglu M. (1988) Structure of a hydroxyl radical induced crosslink of thymine and tyrosine. Biochemistry, 27, 6353-6359.

203. Carmichael, P.L. She M.N. and Phillips D.H. (1992) Detection and characterization by ${ }^{32}$ P-postlabelling of DNA adducts induced by a Fenton-type oxygen radical-generating system. Carcinogenesis, 13, 1127-1135.

204. Gerschman. K., Gilbert D.L., Nyc S.W., Dwyer S. and Fenn W.O. (1954) Oxygen poisoning and X-irradiation: a mechanism in common. Science, 119, 623-626.

205. Fridovich, I. (1989) Superoxide dismutases. An adaptation to a paramagnetic gas. J Biol Chem, 264. 7761 7764.

206. Fraga. C.G., Shigenaga M.K.. Park J.W., Degan P. and Ames B.N. (1990) Oxidative damage to DNA during aging: 8-hydroxy-2'-deoxyguanosine in rat organ DNA and urinc. Proc Nall Acad Sci U S A, 87, 4533-4537.

207. Hayakawa, M., Torii K., Sugiyama S., Tanaka M. and Ozawa T. (1991) Age-associated accumulation of 8 hydroxydeoxyguanosine in mitochondrial DNA of human diaphragm. Biochem Biophys Res Commun, 179, $1023-1029$.

208. Cadet, J., Berger M.. Douki T. and Ravanat J.L. (1997) Oxidative damage to DNA: formation. measurement, and biological significance. Rev Physiol Biochem Pharmacol, 131, 1.87.

209. Asami, S., Manabe H., Miyake J., Tsurudome Y., Hirano T., Yamaguchi R., Itoh H. and Kasai H. (1997) Cigarette smoking induces an increase in oxidative DNA damage, 8-hydroxydeoxyguanosine, in a central site of the human lung. Carcinogenesis, 18, 1763-1766.

210. Inoue, M., Osaki T., Noguchi M., Hirohashi S., Yasumoto K. and Kasai H. (1998) Lung cancer patients have increased 8-hydroxydeoxyguanosine levels in peripheral lung tissue DNA. Jpn J Cancer Res. 89, 691-695.

211. Hardie, L.J., Briggs J.A., Davidson L.A., Allan J.M., King R.F., Williams G.I. and Wild C.P. (2000) The effect of $h O G G l$ and glutathione peroxidase 1 genotypes and $3 p$ chromosomal loss on 8-hydroxydeoxyguanosine levels in lung cancer. Carcinogenesis, 21, 167-172.

212. Asami, S., Hirano T., Yamaguchi R., Tomioka Y.. Itoh H. and Kasai H. (1996) Increase of a type of oxidative DNA damage, 8-hydroxyguanine, and its repair activity in human lcukocytes by cigarette smoking. Cancer Res. 56. 2546-2549.

213. Van Zeeland. A.A., de Groot A.J., Hall J. and Donato F. (1999) 8-Hydroxydcoxyguanosine in DNA from leukocytes of healthy adults: relationship with cigarette smoking, environmental tobacco smoke, alcohol and coffee consumption. Mutat Res, 439, 249-257.

214. Erzurum, S.C., Danel C.. Gillissen A., Chu C.S., Trapnell B.C. and Crystal R.G. (1993) In vivo antioxidant gene expression in human airway epithelium of normal individuals exposed to $100 \% \mathrm{O}_{2}$. J Appl Physiol, 75. $1256-1262$.

215. Rahman. I. and MacNee W. (1999) Lung glutathione and oxidative stress: implications in cigarctte smokeinduced airway disease. Am J Physiol, 277, L1067-L1088.

216. Comhair. S.A., Lewis M.J., Bhathena P.R., Hammel J.P. and Erzurum S.C. (1999) Increased glutathione and glutathione peroxidase in lungs of individuals with chronic beryllium discase. Am I Respir Crit Care Med, 159 , 1824-1829. 
217. Mezzeti. A., Lapenna D., Pierdomenico S.D., Calafiore A.M., Costantini F., Riario-Sforza G., Imbastaro T., Neri M. and Cuccurullo F. (1995) Vitamins E, C and lipid peroxidation in plasma and arterial tissue of smokers and non-smokers. Atherosclerosis, 112, $91-99$.

218. Lykkesfeldt. J., Prieme H., Loft S, and Poulsen H.E. (1996) Effect of smoking cessation on plasma ascorbic acid concentration. Bmj, 313. 91.

219. Marnett, L.J. (2000) Oxyradicals and DNA damage. Carcinogenesis, 21, 361-370.

220. Shigenaga, M.K., Gimeno C.J. and Ames B.N. (1989) Urinary 8-hydroxy-2'-deoxyguanosine as a biological marker of in vivo oxidative DNA damage. Proc Nall Acad Sci U S A, 86, 9697-9701.

221. Shinmura, K., Kohno T., Kasai H., Koda K., Sugimura H. and Yokota J. (1998) Infrequent mutations of the hOGGl gene, that is involved in the excision of 8-hydroxyguanine in damaged DNA, in human gastric cancer. Jpm J Cancer Res, 89, 825-828.

222. Sugimura, H., Kohno T., Wakai K., Nagura K., Genka K., Igarashi H., Morris B.J., Baba S., Ohno Y., Gao C., Li Z., Wang J., Takezaki T., Tajima K., Varga T., Sawaguchi T., Lum J.K., Martinson J.J., Tsugane S., Iwamasa T., Shinmura K. and Yokota J. (1999) hOGGI Ser326Cys polymorphism and lung cancer susceptibility. Cancer Epidemiol Biomarkers Prev, 8, 669-674.

223. Hall. J., Bresil H., Donato F., Wild C.P., Loktionova N.A.. Kazanova O.I., Komyakov I.P., Lemekhov V.G., Likhachev A.J. and Montesano R. (1993) Alkylation and oxidative-DNA damage repair activity in blood leukocytes of smokers and non-smokers. Im $J$ Cancer, 54, 728-733.

224. Kohno, T., Shinmura K., Tosaka M., Tani M., Kim S.R., Sugimura H., Nohmi T., Kasai H. and Yokota J. (1998) Genetic polymorphisms and alternative splicing of the hOGGl gene, that is involved in the repait of 8hydroxyguanine in damaged DNA. Oncogene, 16, 3219-3225.

225. Loft. S., Vistisen K.. Ewertz M. Tjonneland A., Overvad K. and Poulsen H.E. (1992) Oxidative DNA damage estimated by 8-hydroxydeoxyguanosine excretion in humans: influence of smoking. gender and body mass index. Carcinogenesis, 13, 2241-2247.

226. Yin, B., Whyalt R.M., Perera F.P., Randall M.C., Cooper T.B. and Santelta R.M. (1995) Determination of 8hydroxydeoxyguanosine by an immunoaffinily chromatography-monoclonal antibody-based ELISA. Free Radic Biol Med, 18, 1023-1032.

227. Prieme, H.. Nyyssonen K.. Gronbaek K.. Klarlund M., Loft S., Tonnesen P., Salonen J.T. and Poulsen H.E. (1998) Randomized controlled smoking cessation study: transient increase in plasma high density lipoprotein but no change in lipoprotein oxidation resistance. Scand J Clin Lab Invest, 58, I1-18.

228. Spicer, S.S., Chakrin L.W. and Wardell J.R. (1973) Respiratory mucous secretion. In Dulfano, M.J. (ed.), Sputum, fundamental and clinical pathology. Charles C Thomas Publisher, lllinois, pp. 22-68.

229. Carson, S., Goldhamer R. and Carpenter R. (1966) Mucus transport in the respiratory tract. Symposium on stracture, function and measurement of respiratory cilia. Am Rev Resp Dis, 93, 86.

230. Dulfano, M.J. and Philippoff W. (1973) Physical properties. In Dulfano, M.J. (ed.), Sputum, fundamental and clinical pathology. Charles C Thomas Publisher, Illinois, pp. 201-242.

231. Sakula, A. (1986) Charcot-Leyden crystals and Curschmann spirals in asthmatic sputum. Thorax, 41, 503-507.

232. Morrow Brown. H. (1958) Treatment of chronic asthma with prednisolone. Significance of cosinophils in the sputum. Lancet, II. 1245-1247.

233. Pavord, I.D., Pizzichini M.M., Pizzichini E. and Hargreave F.E. (1997) The use of induced sputum to investigate airway inflammation. Thorax, 52, 498-501.

234. Pin, 1., Gibson P.G., Kolendowice R., Girgis-Gabardo A., Denburg J.A., Hargreave F.E. and Dolovich J. (1992) Use of induced sputum cell counts to investigate airway inflammation in asthma. Thorax, 47, 25-29.

235. Wooten, O.J. and Dulfano M.J. (1978) Improved homogenization techniques for sputum cytology counts. Ann Allergy. 41. 150-154.

236. Hulka, B. (1990) Overview of biological markers. In Hulka, B.S., Wilcosky, T. and Griffith, J. (eds), Biological markers in epidemiology. Oxford University Press. New York, pp. 3-15.

237. Wilcosky, T.C. and Griffith J.D. (1990) Application of biological markers. In Hulska, B.S., Wilcosky, T.C. and Griffith. J.D. (eds), Biological markers in epidemiology. Vol. 1. Oxford University Press, New York, pp. 16. 27.

238. Wilcosky, T.C. (1990) Criteria for selecting and evaluating markers. In Hulska, B.S., Wilcosky, T.C. and Griffith, J.D. (eds), Biological markers in epidemiology. Oxford University Press, New York. pp. 28-55.

239. Hulka, B.S. (1990) Methodological issues in molecular cpidemiology. In Hulka, B.S., Wilcosky, T. and Griffith, J. (eds), Biological markers in epidemiology. Oxford University Press, New York, pp. 214-226. 
CHAPTER 2

INDUCED SPUTUM FOR DOSIMETRY OF EXPOSURE TO CARCINOGENS 


\title{
Applicability of induced sputum for molecular dosimetry of exposure to inhalatory carcinogens: ${ }^{32}$ P-postlabeling of lipophilic-DNA adducts in smokers and non-smokers
}

\author{
A. Besarati Nia', L.M. Maas', S.G.J. Van Breda', D.M.J. Curfs', J.C.S. Kleinjans', E.F.M. Wouters',
} F.J. Van Schooten ${ }^{1 *}$

'Department of Health Risk Analysis and Toxicology, Maastricht University, Maastricht, The Netherlands

${ }^{2}$ Department of Pulmonology, Academic Hospital Maastricht, Maastricht, The Netherlands

\section{ABSTRACT}

The lung is a major target organ for smoking-associated cancer. We examined the applicability of induced sputum for molecular dosimetry of exposure to smoke-related carcinogens. Sputum induction was performed by inhalation of $4.5 \%$ saline delivered from an ultrasonic nebulizer for a period of up to $21 \mathrm{~min}$ in a group of healthy smokers $(n=20)$ and non-smokers $(n=24)$. Induced sputum samples were analyzed for total and differential cell counts and cell viability. Subsequently, DNA contents of the samples were isolated and measurement of lipophilic DNA adducts was done using the ${ }^{32} \mathrm{P}$-postlabeling assays enhanced by nuclease P1 (NP1) digestion and butanol extraction methods. All subjects tolerated the induction procedure without experiencing any troublesome symptoms, and $90 \%$ of smokers ( 18 of 20 ) and $88 \%$ of non-smokers ( 21 of 24 ) produced sufficient amounts of sputum. Total cell counts and percentages of viable cells in smokers were higher than those in non-smokers $\left(6.7 \pm 6.0\right.$ versus $4.7 \pm 6.0 \times 10^{6}, \mathrm{P}=0.40$, and $80 \pm 15$ versus $63 \pm 17, \mathrm{P}=0.01$, respectively). In cell differentials, smokers had lower percentages of bronchoalveolar macrophages and higher percentages of neutrophils ( $69 \pm 24$ versus $92 \pm 5, P=0.002$, and 26 \pm 26 versus $4 \pm 4, \mathrm{P}=0.008$, respectively). Utilizing the NP1 digestion method, all smokers and only one non-smoker showed a diagonal radioactive zone (DRZ) in their adduct maps; adduct levels in smokers were higher than those in non-smokers $(3.1 \pm 1.4$ versus $0.6 \pm$ $0.8 / 10^{8}$ nucleotides, $P=0.0007$ ), and also adduct levels were significantly related to smoking indices. Applying the butanol extraction method, however, only half of the smokers and three non-smokers showed a DRZ in their adduct maps; adduct levels in smokers were higher than those in non-smokers ( $4.6 \pm 3.7$ versus $1.0 \pm 1.9 / 10^{8}$ nucleotides, $\left.\mathrm{P}=0.02\right)$, and the levels of adducts were significantly related to the smoking indices. There was a correlation between the levels of adducts determined by the two enrichment methods ( $r=0.7, P=0.02$ ). Paired comparison showed no differences between the levels of adducts quantified by the two methods $(P=0.55)$. We conclude that induced sputum can serve for molecular dosimetry of exposure to inhalatory carcinogens, and that the NP1 version of the ${ }^{32} \mathrm{P}$-postlabeling assay is a choice of preference for studying smoking-induced DNA adducts in the lower respiratory tract.

Based on the manuscript published in:

"Cancer Epidem Biomarkers Prev (2000) 9, 367-372" 


\section{Chapter Two}

\section{Induced sputum for dosimetry of exposure to carcinogens}

\section{INTRODUCTION}

Lung cancer is a leading cause of cancer-related death worldwide, and it is taking a toll of over 3 million lives, annually (1,2). Epidemiological data have shown an indisputable link between tobacco smoking and lung cancer (3-5); $80-85 \%$ of lung cancer cases are attributed to tobacco smoking (3-6) and $10-15 \%$ of lifetime smokers develop lung cancer $(4,6,7)$. Because survival after diagnosis of lung cancer is poor and early detection is scarce (7), interventions can only be aimed at prevention e.g., by removing the risk factors and/or by identifying the individuals at high risk.

Two main classes of carcinogens present in tobacco smoke are polycyclic aromatic hydrocarbons and aromatic amines $(3,8,9)$. The chemical carcinogenicity of these compounds is mainly ascribed to the capability of their reactive metabolites to covalently bind to cellular DNA and form DNA adducts $(8,10)$. Because formation of DNA adducts appears to be a crucial step in initiating carcinogenesis, examination of DNA for the presence of adducts could serve as a valuable means for assessing exposure to carcinogens as well as risk for cancer (11). To date, the ${ }^{32} \mathrm{P}$-postlabeling assay is the most widely used method for DNA adduct dosimetry (12). Significant advantages of this assay are its high sensitivity (1 adduct $/ 10^{9}-10^{10}$ unmodified nucleotides), its requirement for only low amounts of DNA (1 $5 \mu \mathrm{g}$ ) and its ability to detect DNA adducts formed by complex mixtures (13).

So far, measurement of DNA adducts to study smoking-induced lung cancer has often been performed in surrogate tissues such as white blood cells (WBC) and occasionally, in biopsy or autopsy samples from the lung (14-24). However, the inconsistent surrogacy of WBC for the lung (25-29) and the infeasibility of sampling lung tissue on a routine basis and in a non-invasive fashion, have urged the need to identify other alternative tissues.

Sputum has been in clinical practice since the last half of the $19^{\text {th }}$ century when its macroscopic and/or microscopic examinations were used to investigate airway inflammation (30). With the recent innovations in sputum induction technique, this matrix has re-emerged in clinical research (31-34). Currently, sputum induction is considered as a non-invasive, easy to perform, inexpensive and well-tolerated method for sampling lower respiratory tract of humans (33).

In the present study, we examined whether induced sputum can be used for molecular dosimetry of exposure to tobacco smoke carcinogens. For this purpose, we measured the levels of lipophilic-DNA adducts in induced sputum cells of smokers and non-smokers by means of the ${ }^{32} \mathrm{P}$-postlabeling assay utilizing nuclease P1 (NP1) digestion and butanol extraction as enrichment methods. 


\section{MATERIAL AND METHODS}

\section{Study Population}

Volunteers were recruited by advertising in the local newspapers. Upon enrollment, every individual filled out a self-administered questionnaire and signed an informed consent. The volunteers were scrutinized thoroughly based on the information elicited from the questionnaires with regard to their age, sex, smoking behavior, alcohol consumption, medical history of disease, dietary/medicinal/occupational exposure to known carcinogens and familial history of cancer. Accordingly, two groups of healthy individuals consisting of 20 smokers [age, $39 \pm 11$; smoking status, $17 \pm 8$ cigarettes/day], and 24 lifelong non-smokers [age, $34 \pm$ 8] with no occupational exposure to tobacco-related carcinogens were selected. Before sampling, all participants were interviewed in detail and briefed for sputum induction procedure. Table 1 summarizes the characteristics of the study population. The study was approved by the Medical Ethical Commission of Maastricht University.

Table 1. Characteristics of the study population and summary of DNA adducts analysis

\begin{tabular}{|c|c|c|}
\hline & Smokers & Non-smokers \\
\hline Number & 20 & 24 \\
\hline Gender (male/female) & $7 / 13$ & $6 / 18$ \\
\hline Age $^{a}$ & $39 \pm 11$ & $34 \pm 8$ \\
\hline Cigarettes $/$ day $^{\prime \prime}$ & $17 \pm 8$ & 0 \\
\hline Tar/day (mg) & $345 \pm 196$ & 0 \\
\hline Smoking years" & $20 \pm 10$ & 0 \\
\hline Pack years ${ }^{\mathrm{j}}$ & $18 \pm 14$ & 0 \\
\hline Sputum induction (success/failurc) & $18 / 2$ & $21 / 3$ \\
\hline Lipophilic-DNA adducts (NPI digestion) ${ }^{\text {a.h }}$ & $3.1 \pm 1.4^{\mathrm{c}}$ & $0.6 \pm 0.8$ \\
\hline Lipophilic-DNA adducts (Butanol extraction) ${ }^{3 . h}$ & $4.6 \pm 3.7^{\mathrm{d}}$ & $1.0 \pm 1.9$ \\
\hline
\end{tabular}

'Results expressed as mean $\pm \mathrm{SD}$.

'Adducts $/ 10^{8}$ nucleotides as determined by ${ }^{32} \mathrm{P}$-postlabeling.

'Statistically significant compared to non-smokers; $P=0.007$.

dStatistically significant compared to non-smokers; $\mathrm{P}=0.02$.

\section{Sputum Induction}

Subjects were pretreated with $200 \mu \mathrm{g}$ of salbutamol administered via an inhalatory chamber [medication was given prophylactically in order to reverse bronchoconstriction if any]. Sputum induction was performed by inhalation of ultrasonically nebulized $4.5 \%$ saline 
delivered from an Ultra-Neb ${ }^{\mathrm{TM}} 2000$ (De Vilbiss, Somerset, PA). Total inhalation time was 21 min with three 5 -min intervals at the end of each 7 -min period. During the intervals, subjects rinsed their mouths, gargled their throats and then, coughed up all produced expectorate into a 50-ml Greiner tube (Greiner Labortechnik, Frickenhausen, Germany) placed on ice. Additionally, they were advised to cough up the available expectorate at any moment regardless of the time of induction. Induction was terminated as soon as sufficient amount of sputum [at least $5 \mathrm{ml}$ ] was obtained.

\section{Sputum Processing}

Processing of induced sputum was done within $2.5 \mathrm{~h}$ of sampling. The volume of the sample was measured and four volumes of $0.1 \%$ Sputolysine (Calbiochem-Novabiochem Corp., La Jolla, CA) were added to produce mucolysis and rid sputum of its gelatinous form. The solution was gently aspirated with a $5-\mathrm{ml}$ pipette for several times, and placed in a shaking water bath for $15 \mathrm{~min}$ at $37^{\circ} \mathrm{C}$. Intermittently, the sample was vortexed two to four times for 15 sec each time. To quench the activity of the Sputolysine, a further 4 volumes of phosphate buffered saline (PBS) ( $\mathrm{pH} 7.4$ ) were added to the sample and shaking continued for another 5 $\min$. The resulting homogenate was centrifuged at $725 \times \mathrm{g}$ for $10 \mathrm{~min}$ at $4^{\circ} \mathrm{C}$. Supernatant was discarded and the pellet was resuspended in $2 \mathrm{ml}$ of PBS from which $100 \mu \mathrm{l}$ was used for cytological examination and the remaining was re-pelleted to be preserved at $-80^{\circ} \mathrm{C}$ until DNA isolation. Determinations of cell viability [according to trypan blue exclusion technique] and total cell counts were carried out using $10 \mu \mathrm{l}$ of the cell suspension in a standardized haemocytometer. From the remaining cell suspension, an aliquot of $30 \times 10^{3}$ cells (diluted in PBS to a final volume of $300 \mu \mathrm{l}$ ) was cytocentrifuged (Shandon Cytospin ${ }^{\odot}$, Cheshire, UK) at $1500 \mathrm{rpm}$ for $5 \mathrm{~min}$ onto Polysine ${ }^{\mathrm{TM}}$ microslides (E. Merck Nederland B.V., Amsterdam, the Netherlands). The slides were stained with May-Grünwald Giemsa and cell differential was done through counting 500 non-squamous cells.

\section{DNA Isolation}

Cell pellet was thawed and subsequently, lysed with $400 \mu \mathrm{l}$ of SET/SDS [ $100 \mathrm{mM} \mathrm{NaCl}, 20$ $\mathrm{mM}$ EDTA, $50 \mathrm{mM}$ Tris, $0.5 \%$ sodium dodecyl sulfate, (pH 8.0 )] at $37^{\circ} \mathrm{C}$, overnight. The resulting suspension was treated with $50 \mu \mathrm{l}$ RNAse mixture $[0.1 \mathrm{mg} / \mathrm{ml}$ RNAse $A$ and 1000 $\mathrm{U} / \mathrm{ml}$ RNAse T1] for $3 \mathrm{~h}$ at $37^{\circ} \mathrm{C}$, followed by a treatment with $75 \mu \mathrm{l}$ Proteinase $\mathrm{K}[10 \mathrm{mg} / \mathrm{ml}]$ for $2 \mathrm{~h}$ at $37^{\circ} \mathrm{C}$. DNA was isolated by repetitive extraction with phenol/chloroform/isoamyl alcohol [25:24:1] and chloroform/isoamyl alcohol [24:1] and then, precipitated with two volumes of $100 \%$ cold ethanol and $1 / 30$ volume of $3 \mathrm{M}$ sodium acetate ( $\mathrm{pH}$ 5.3). Precipitated DNA was rinsed with $70 \%$ ethanol and dissolved in $2 \mathrm{mM}$ Tris ( $\mathrm{pH} 7.4$ ). The purity and concentration of DNA were determined spectrophotometrically by absorbance at 230, 260 and $280 \mathrm{~nm}$ and afterwards, its concentration was adjusted to $2 \mathrm{mg} / \mathrm{ml}$. 


\section{${ }^{32}$ P-postlabeling Assay}

The ${ }^{32} \mathrm{P}$-postlabeling assay was performed as described earlier (35). Briefly, $5 \mu \mathrm{g}$ of DNA was digested into deoxyribonucleoside 3 '-monophosphates using micrococcal endonuclease $[0.25 \mathrm{U} / \mu \mathrm{l}]$ and spleen phosphodiesterase $[2 \mu \mathrm{g} / \mu \mathrm{l}]$. Half of the digest was treated with NP1 $[2.5 \mathrm{~g} / \mu \mathrm{l}]$ or alternatively, extracted with 1-butanol according to the method of Gupta (36). Subsequently, the modified nucleotides were labeled with $\left[\gamma-{ }^{32} \mathrm{P}\right]$-ATP in the presence of T4polynucleotide kinase. Radiolabeled adducted nucleotide biphosphates were separated by twodimensional chromatography on polyethyleneimine (PEI) -cellulose sheets (Macherey Nagel, Düren, Germany) using the following solvent systems: $\mathrm{D}_{1}, 1 \mathrm{M} \mathrm{NaH} \mathrm{PO}_{4}$ (pH 6.5); $\mathrm{D}_{2}, 8.5$ $\mathrm{M}$ Urea, 5.3 M Lithiumformate ( $\mathrm{pH} 3.5$ ); $\mathrm{D}_{3}, 1.2 \mathrm{M}$ Lithiumchloride, $0.5 \mathrm{M}$ Tris, 8.5 Urea ( $\mathrm{pH} 8.0$ ), and $\mathrm{D}_{4}, 1.7 \mathrm{M} \mathrm{NaH}_{2} \mathrm{PO}_{4}(\mathrm{pH} 6.0$ ). To ensure the efficiency of nuclease $\mathrm{Pl}$ treatment and ATP excess, an aliquot of the digest was one-dimensionally chromatographed on PEI-cellulose sheet (Merck, Darmstadt, Germany) using a solvent system of $0.12 \mathrm{M}$ $\mathrm{NaH}_{2} \mathrm{PO}_{4}$ ( $\mathrm{pH} 6.8$ ). For quantification purposes, 2 standards of $\left.{ }^{3} \mathrm{H}\right] \mathrm{BPDE}$ modified DNA with known modification levels of 1 adduct $/ 10^{7}$ and $10^{8}$ unmodified nucleotides were parallelly run in all experiments. Quantification was performed using a phosphor imager (Molecular Dynamics ${ }^{\mathrm{TM}}$, Sunnyvale, CA) with a detection limit of 1 adduct $/ 10^{\circ}$ nucleotides. Quantitatively, half of the detection limit for diagonal radioactive zone (DRZ) 0.25 adducts $/ 10^{8}$ nucleotides] was considered as the determined level of adducts for samples which showed neither a DRZ nor an adduct spot in their adduct maps. To assess the efficiency of labeling in NP1 digestion and butanol extraction methods, standards of $\left[{ }^{3} \mathrm{H}\right] \mathrm{BPDE}$ modified DNA with known modification levels were enriched by the respective methods and assayed simultaneously $(n=4)$. Adduct recoveries in the NP1 digestion and butanol extraction methods were $69 \pm 2.6 \%$ and $39 \pm 4.6 \%$, respectively. Nucleotide quantification was done by labeling the remaining half of the digested DNA with $\left[\gamma^{32} \mathrm{P}\right]-\mathrm{ATP}[15 \mu \mathrm{Ci}]$ under the same condition as described above, followed by one-dimensional chromatography on PEI-cellulose sheet using a solvent system of $0.12 \mathrm{M} \mathrm{NaH}_{2} \mathrm{PO}_{4}$ ( $\mathrm{pH}$ 6.8). Samples with evident protein and/or RNA contaminations were excluded from the analysis.

\section{Statistical Analysis}

Results were expressed as mean \pm standard deviation. In all cases, comparisons were made using the unpaired Student's $t$-test unless otherwise indicated. Simple linear regression analysis was performed to study the relationships between different variables. Statistical significance was considered at $\mathrm{P}<0.05$. 
Smokers had lower percentages of bronchoalveolar macrophages (BAM) $(P=0.002)$ and higher percentages of neutrophils $(\mathrm{P}=0.008)$ as compared to non-smokers. Percentages of neutrophils were related to smoking indices as follows: number of cigarettes smoked per day $(\mathrm{r}=0.4, \mathrm{P}=0.04)$, amount of tar consumed per day [tar content of cigarette $\mathrm{X}$ number of cigarettes smoked per day, $r=0.5, P=0.02$ ] and pack years [number of cigarettes smoked per day $/ 20 \times$ smoking years, $r=0.4, P=0.03]$. DNA yields were related to total cell counts $(r=0.7$, $\mathrm{P}=0.0001$ ), and smokers had higher DNA yields [adjusted for total cell counts] compared to non-smokers $(56 \pm 55$ versus $30 \pm 35 \mu \mathrm{g}, \mathrm{P}=0.14)$. Samples with high percentages of squamous cells $(>40 \%)$ and low total cell counts $\left(<1 \times 10^{6}\right)$ were excluded from the ${ }^{32} \mathrm{P}$ postlabeling analysis [technically, the presence of squamous cells in induced sputum is an indication of the salivary contamination $(37,38)$ and the DNA yield of $1 \times 10^{6}$ cells $\{\sim 5 \mu \mathrm{g}\}$ is just sufficient for one ${ }^{32} \mathrm{P}$-postlabeling analysis].

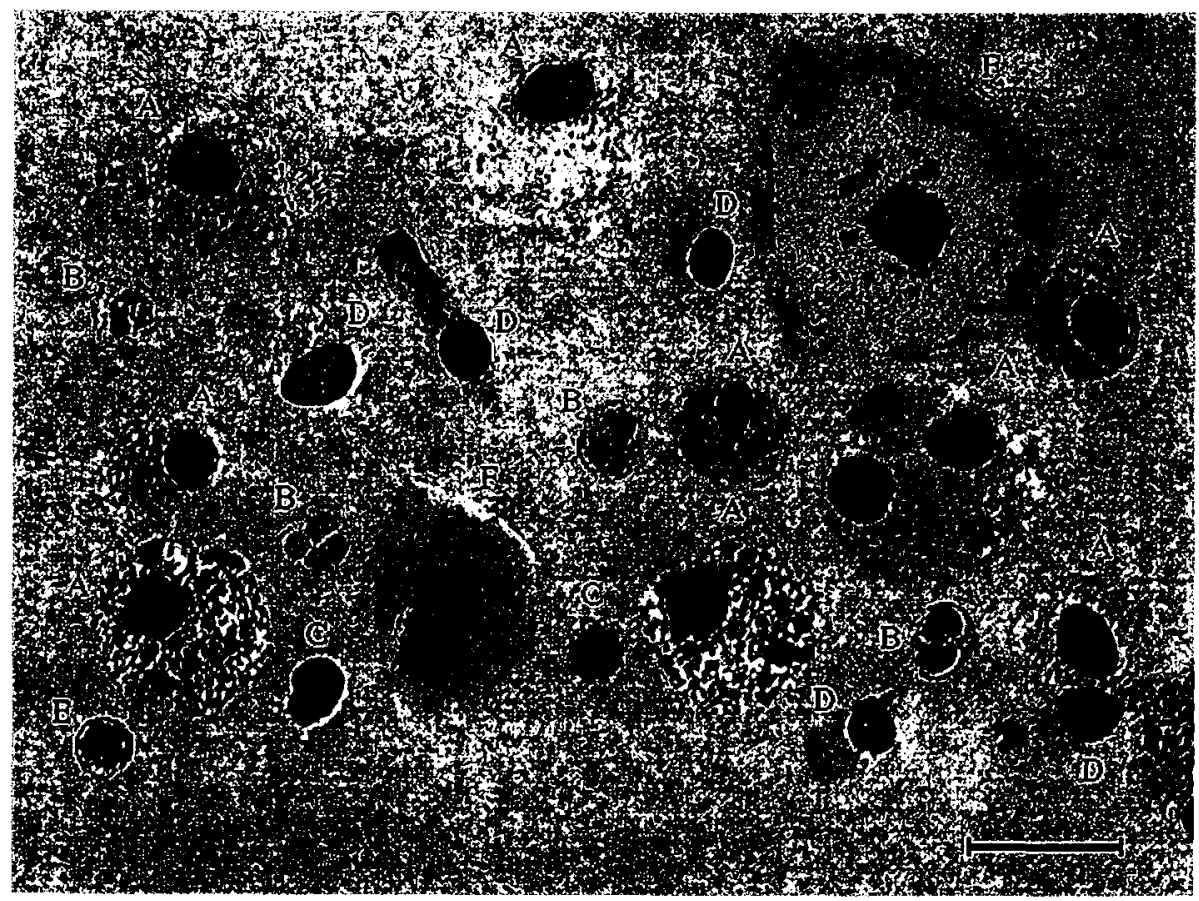

Fig. 1. Representative cell composition of induced sputum sample from a smoker [for visualization, threc sections of the slide are assembled together by Image Processing and Analysis System (Quantimet 500, Leica, Cambridge, UK)], A, BAM; B, Neutrophil; C, Bronchoepithelial cell; D, Ciliated cell; E, Lymphocyte; F, Squamous cell. May Grünwald-Giemsa staining. Magnification X 400. bar, $30 \mu \mathrm{m}$. 
Smokers had lower percentages of bronchoalveolar macrophages (BAM) $(P=0.002)$ and higher percentages of neutrophils $(\mathrm{P}=0.008)$ as compared to non-smokers. Percentages of neutrophils were related to smoking indices as follows: number of cigarettes smoked per day $(r=0.4, P=0.04)$, amount of tar consumed per day [tar content of cigarette $X$ number of cigarettes smoked per day, $r=0.5, P=0.02$ ] and pack years [number of cigarettes smoked per day/20X smoking years, $r=0.4, P=0.03]$. DNA yields were related to total cell counts $(r=0.7$, $\mathrm{P}=0.0001$ ), and smokers had higher DNA yields [adjusted for total cell counts] compared to non-smokers $(56 \pm 55$ versus $30 \pm 35 \mu \mathrm{g}, \mathrm{P}=0.14$ ). Samples with high percentages of squamous cells $(>40 \%)$ and low total cell counts $\left(<1 \times 10^{6}\right)$ were excluded from the ${ }^{32} \mathrm{P}$ postlabeling analysis [technically, the presence of squamous cells in induced sputum is an indication of the salivary contamination $(37,38)$ and the DNA yield of $1 \times 10^{6}$ cells $\{\sim 5 \mu \mathrm{g}\}$ is just sufficient for one ${ }^{32} \mathrm{P}$-postlabeling analysis].

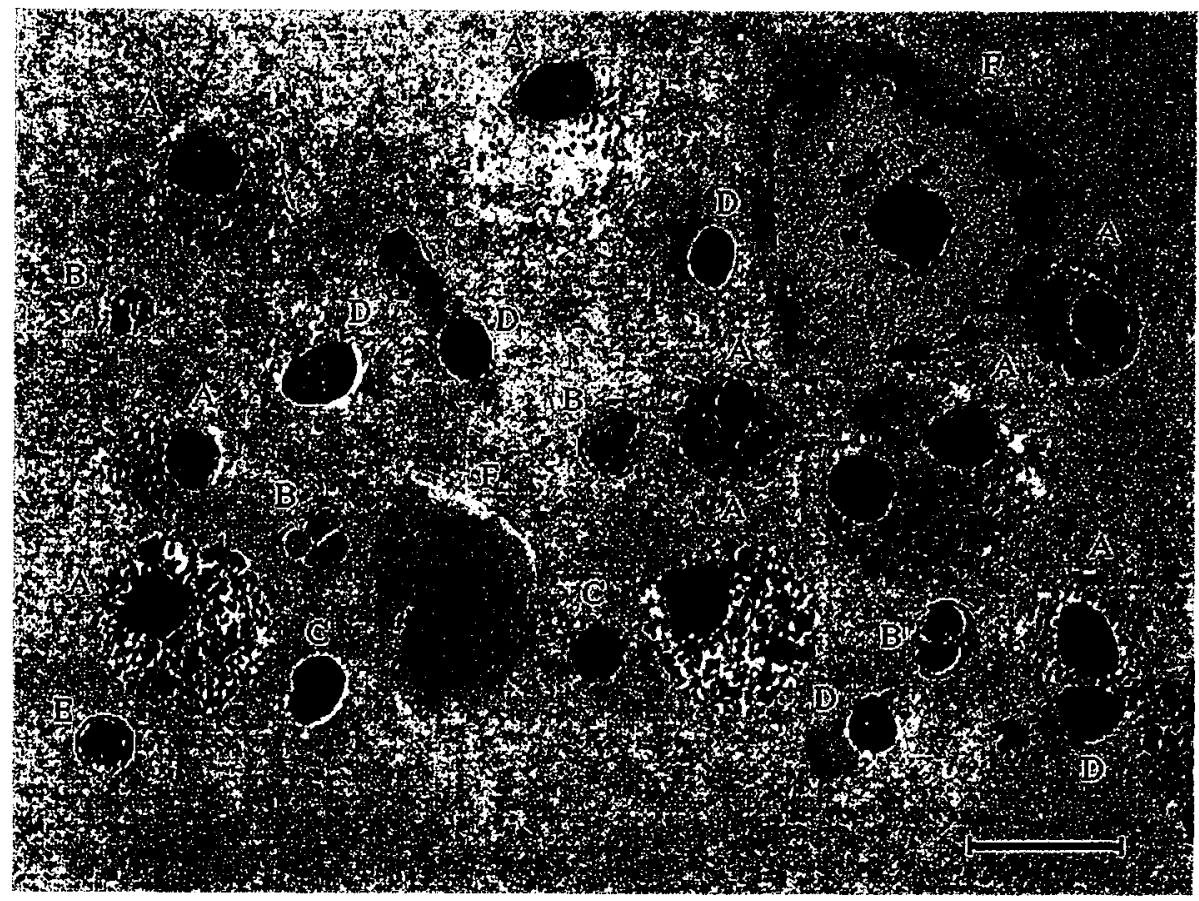

Fig. 1. Representative cell composition of induced sputum sample from a smoker [for visualization, three sections of the slide are assembled together by Image Processing and Analysis System (Quantimet 500, Leica, Cambridge, UK)], A, BAM; B, Ncutrophil; C, Bronchoepithelial cell; D, Ciliated cell; E, Lymphocyte; F, Squamous cell. May Grünwald-Giemsa staining. Magnification X 400. bar, $30 \mu \mathrm{m}$. 


\section{${ }^{32}$ P-postlabeling of Lipophilic-DNA Adducts}

Figure $2[\mathrm{~A}, \mathrm{~B}]$ depicts the representative chromatograms of ${ }^{32} \mathrm{P}$-postlabelled DNA adducts from a smoker and a non-smoker, respectively, by the NPI digestion method. In this version of the ${ }^{32} \mathrm{P}$-postlabeling assay, all smokers and only one non-smoker showed a DRZ in their adduct maps. Adduct levels in smokers were higher than those in non-smokers $(P=0.0007)$ [Tab. 1]. Levels of adducts in smokers and non-smokers ranged from 1.8 to 5.6 and from 0.3 to $1.9 / 10^{8}$ nucleotides, respectively. Distribution of the levels of adducts in smokers and nonsmokers are shown in Figure 3. Adduct levels were related to the number of cigarettes smoked per day $(r=0.6, P=0.007)$, amount of tar consumed per day $(r=0.7, P=0.006)$ and pack years $(r=0.6, P=0.01)$.

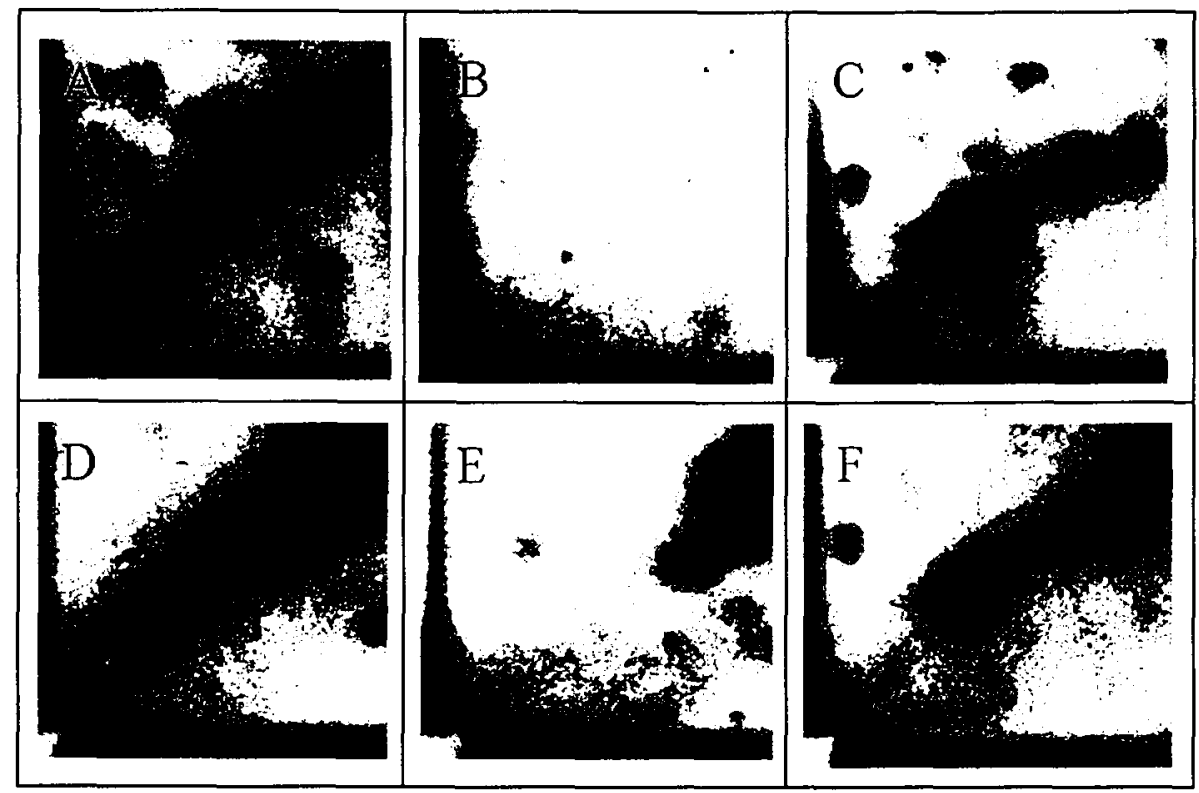

Fig. 2. Representative chromatograms of the ${ }^{32} \mathrm{P}$-postlabelled DNA adducis in induced sputum of a smoker and a non-smoker by the NPI digestion method (A, B, respectively) and by butanol extraction method (D, E, respectively; the radioactivity in the upper left-hand corner was also observed at the same location in standard DNA and therefore, considered as background). Panels $C$ and F represent BPDE-DNA adduct standards (1 adduc $110^{7}$ nucleotides) determined by the NPI and butanol enrichment methods, respectively.

By butanol extraction method of the ${ }^{32} \mathrm{P}$-postlabeling assay, however, only half of the smokers and three non-smokers showed a DRZ in their adduct maps [Fig. 2 [D, E]]. Adduct levels in smokers were higher than those in non-smokers $(P=0.02)$ [Tab. 1]. Levels of adducts in smokers and non-smokers varied in the range of $0.3-10.0$, and $0.3-4.1 / 10^{8}$ nucleotides, 
respectively [Fig. 3]. Adduct levels were also related to smoking indices as follows: number of cigarettes smoked per day $(r=0.6, P=0.01)$, amount of tar consumed per day $(r=0.5, P=$ $0.06)$ and pack years $(r=0.6, P=0.01)$. There was a correlation between the levels of adducts measured by the butanol extraction method and those quantified by the NP1 digestion method $(r=0.7, P=0.02)$. Paired comparison showed no differences between the levels of adducts determined by the two enrichment methods (paired Student's $t$-test, $P=0.55$ ).

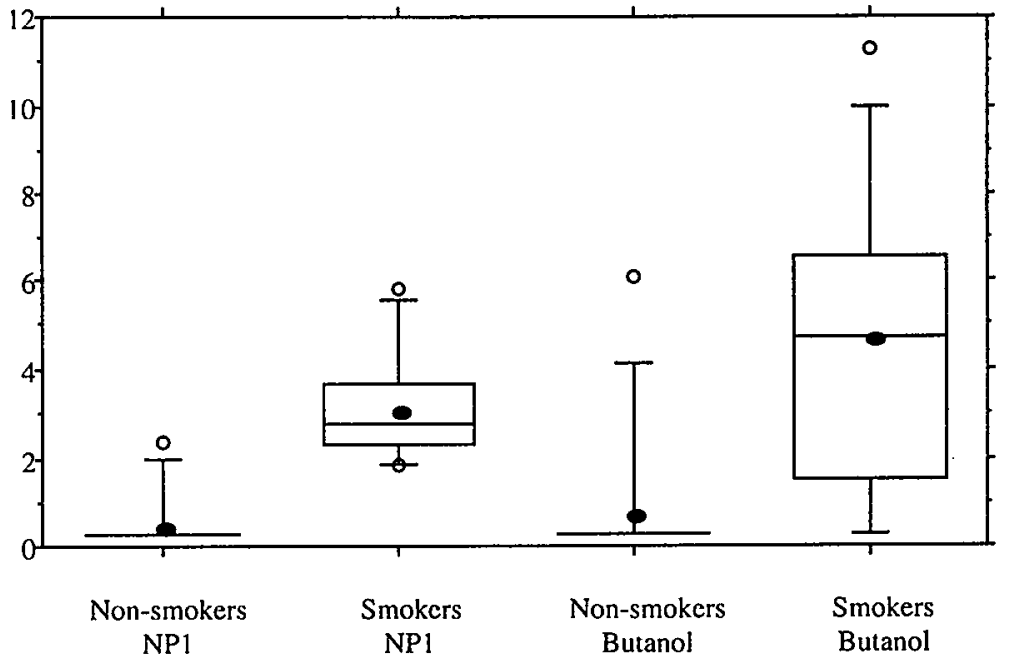

Fig.3. Levels of lipophilic-DNA adducts in induced sputum of smokers and non-smokers determined by the $\mathrm{NPI}$ digestion and butanol cxtraction versions of the ${ }^{32} \mathrm{P}$-postlabcling assay. The lower and upper edges of the boxes, the $25^{\text {th }}$ and the $75^{\text {th }}$ percentiles, respectively. $O$ and - within the boxes, the means and the medians, respectively. Lower and upper bars, the $10^{\text {th }}$ and the $90^{\text {th }}$ percentiles, respectively. o, Individual values $<10^{\text {th }}$ or $>90^{\text {th }}$ percentiles.

\section{DISCUSSION}

The high success rate for sputum induction shown in the present study is in favor of the feasibility and reproducibility of this technique for sampling healthy individuals. This is of importance because the applicability of this technique has mainly been demonstrated in patients with respiratory disorders who are likely to produce sputum even spontaneously (33). Apart from a few clinical studies (38-45) in which sputum induction has been performed in a small number of non-diseased controls, our study is the first one that shows the plausibility of this technique in a relatively large number of healthy volunteers.

The results of cytological examinations are in good agreement with the findings of other clinical studies $(38,39,43)$; however, our cell differential data are partially different from those of one recent study (45). Similar to that study, we observed inter-related percentages of BAM 
and neutrophils in both smokers and non-smokers. In contrast, we found higher percentages of neutrophils and lower percentages of BAM in smokers as compared to non-smokers (45). This latter discrepancy could have arisen from the incomparability of the study populations (45). In fact, smokers are likely to have higher percentages of neutrophils as compared to nonsmokers because smoking induces inflammation in the airway where neutrophils function as the first line of inflammatory cells (46). Interestingly, the significant dose-response relationship between the percentages of neutrophils and the smoking indices shown in our study supports this idea.

Applying the NP1 and butanol enrichment methods of the ${ }^{32} \mathrm{P}$-postlabeling assay, we found significant differences in DNA adduct profiles between smokers and non-smokers. Of course, the differences were more pronounced when the former method was used. Utilizing the NP1 digestion method, we observed a DRZ, the indicator of exposure to complex mixture of chemical carcinogens $(47,48)$, in the adduct maps of all smokers and only one non-smoker. However, using the butanol extraction method, only half of the smokers and also three nonsmokers showed a DRZ in their adduct maps. This might be ascribed to the fact that butanol extraction method enriches a wide range of adducts some of which are non-specific for tobacco smoke $(49,50)$. Conceivably, the herein lower recovery of BPDE-DNA adducts by butanol extraction method reinforces this view. Furthermore, we found significantly higher levels of DNA adducts in smokers as compared to non-smokers using both NP1 digestion and butanol extraction methods. Also, the determined levels of adducts by both methods were dose-dependently related to the smoking indices. Altogether, it appears that dosimetry of lipophilic-DNA adducts in induced sputum can reflect both the concrete exposure to tobacco smoke as well as the magnitude of such exposure.

It has already been shown that DNA adduct analysis in cells present in bronchoalveolar lavage (BAL) fluid is an informative way of assessing exposure to inhalatory carcinogens $(29,35,51,52)$. Unfortunately, the invasiveness of sampling method has hampered routine application of the BAL cells for molecular dosimetry study of the airway. Comparing the results of the BAL studies with those of ours, we found that in both matrices adduct levels were dose-dependently related to exposure; however, the mean level of adducts in the BAL cells e.g., in a smoking group from one of these studies (35) was two-fold higher than that in induced sputum cells in our study. On the one hand, this may relate to the different exposure levels in the two study groups. Whereas the exposed individuals in the BAL study were heavy smokers [smoking status, $27 \pm 13$ cigarettes/day] (35), the smokers in our study had a moderate smoking status. On the other hand, this discrepancy could also be due to the different cell compositions of the two matrices. In fact, the BAL fluid contains higher percentage of BAM as compared to induced sputum ( $>90$ versus $<70$ ), and it has been shown that BAM has a higher DNA adduct content compared to other cell types (29). Taken together, as the information obtained through the analysis of these two matrices is to a great extent identical and as the sputum induction has the merit of being non-invasive, it can be concluded that induced sputum cells have the potential to substitute the BAL cells for molecular dosimetry study of the airway. 
In summary, we conclude that induced sputum can be used for molecular dosimetry of exposure to inhalatory carcinogens, and that the NP1 version of the ${ }^{32} \mathrm{P}$-postlabeling assay is a preferable choice for studying smoking-related DNA adducts. Prospectively, we plan to validate these results and examine their consistency as compared to the existing inconsistency in the results of DNA adduct analysis in surrogate tissues like WBC (25-29). In addition, we intend to identify the herein detected DNA adducts by immunoassays with antibodies raised against specific DNA adducts, and by the ${ }^{32} \mathrm{P}$-postlabeling assay with reference adducts and non-urea solvent systems (53).

\section{ACKNOWLEDGMENT}

The authors wish to thank all personnel of Lung Function Laboratory, Academic Hospital Maastricht, Maastricht, the Netherlands, for their cooperation during the sampling stage of this study. 


\section{REFERENCE}

1. Pisani, P., Parkin D.M. and Ferlay J. (1993) Estimates of the worldwide mortality from eighteen major cancers in 1985. Implications for prevention and projections of futurc burden. Int $J$ Cancer, 55, 891903.

2. Boyle. P. and Maisonncuve P. (1995) Lung cancer and tobacco smoking. Lung Cancer, 12, 167-181.

3. International Agency for Research on Cancer (1986) Tobacco smoking. In Monographs on the evaluation of the carcinogenic risk of chemicals to humans. Vol. 38. International Agency for Research on Cancer, Lyon (France), pp. 37-375.

4. Loeb, L.A., Ernster V.L., Warner K.E., Abbotts J. and Laszlo J. (1984) Smoking and lung cancer: an overview. Cancer Res, 44, 5940-5958.

5. Hoffmann, D. and Hecht S.S. (1985) Nicotine-derived $N$-nitrosamines and tobacco-related cancer: current status and futurc directions. Cancer Res, 45, 935-944.

6. Surgeon General (1986) The health consequences of involuntary smoking. A report of Surgeon General. Office of Smoking and Health, Rockville (Maryland).

7. Spivack, S.D., Fasco M.J., Walker V.E. and Kaminsky L.S. (1997) The molecular epidemiology of lung cancer. Crit Rev Toxicol, 27, 319-365.

8. Parrikanos, C. and Hoffmann D. (1979) Chemical studies on tobacco smoke. J Anal Toxicol, 3, 184197.

9. Hoflmann, D. and Hoffmann 1. (1997) The changing cigarette, 1950-1995. J Toxicol Environ Heallh, 50, 307-364.

10. Miller, E.C. and Miller J.A. (1981) Searches for ultimate chemical carcinogens and their reactions with cellular macromoleculcs. Cancer, 47, 2327-2345.

11. Hemminki, K. (1993) DNA adducts, mutations and cancer. Carcinogenesis, 14, 2007-2012.

12. Beach, A.C. and Gupta R.C. (1992) Human biomonitoring and the ${ }^{32}$ P-postlabeling assay. Carcinogenesis, 13, 1053-1074.

13. Poiricr, M.C. and Weston A. (1996) Human DNA adduct measurements: state of the art. Environ Health Perspect, 104 Suppl 5, 883-893.

14. Phillips, D.H., Hewer A., Martin C.N., Garner R.C. and King M.M. (1988) Correlation of DNA adduct levels in human lung with cigarette smoking. Nature, 336, 790-792.

15. Perera, F., Mayer J., Jaretzki A., Hcarne S., Brenner D., Young T.L., Fischman H.K., Grimes M., Grantham S., Tang M.X. and et al. (1989) Comparison of DNA adducts and sister chromatid exchange in lung cancer cases and controls. Cancer Res, 49, 4446-4451.

16. Cuzick, J., Routledge M.N., Jenkins D. and Gamer R.C. (1990) DNA adducts in different tissues of smokers and non-smokers. Int J Cancer, 45, 673-678.

17. Van Schooten, F.J., Hillebrand M.J., Van Leeuwen F.E., Lutgerink J.T., Van Zandwijk N., Jansen H.M. and Kriek E. (1990) Polycyclic aromatic hydrocarbon-DNA adducts in lung tissue from lung cancer patients. Carcinogenesis, 11, 1677-1681.

18. Geneste, O., Camus A.M., Castegnaro M., Petruzzelli S., Macchiarini P., Angeletti C.A., Giuntini C. and Bartsch H. (1991) Comparison of pulmonary DNA adduct levels, measured by ${ }^{32} \mathrm{P}$-postlabelling and aryl hydrocarbon hydroxylase activity in lung parenchyma of smokers and ex-smokers. Carcinogenesis, 12, 1301-1305. 
19. Nowak. D., Meyer A., Schmidt-Preuss U., Gatzemeier U., Magnussen H. and Rudiger H.W. (1992) Formation of benzo[a]pyrene-DNA adducts in blood monocytes from lung cancer patients with a familial history of lung cancer. $J$ Cancer Res Clin Oncol, 118, 67-71.

20. Alexandrov, K., Rojas M., Geneste O., Castcgnaro M., Camus A.M., Petruzzelli S., Giuntini C. and Bartsch H. (1992) An improved fluorometric assay for dosimetry of benzo[a]pyrene diol-epoxide-DNA adducts in smokers' lung: comparisons with total bulky adducts and aryl hydrocarbon hydroxylase activity. Cancer Res, 52, 6248-6253.

21. Weston, A., Bowman E.D., Shields P.G., Trivers G.E., Poirier M.C., Santella R.M. and Manchester D.K. (1993) Detection of polycyclic aromatic hydrocarbon-DNA adducts in human lung. Environ Health Perspect, 99, 257-259.

22. Andreassen, A., Kure E.H., Nielsen P.S., Autrup H. and Haugen A. (1996) Comparative synchronous fluorescence spectrophotometry and ${ }^{32} \mathrm{P}$-postlabeling analysis of PAH-DNA adducts in human lung and the relationship to TP53 mutations. Mutat Res, 368, 275-282.

23. Ryberg, D., Skaug V., Hewer A., Phillips D.H., Harries L.W., Wolf C.R., Ogreid D., Ulvik A., Vu P. and Haugen A. (1997) Genotypes of glutathione transferase $\mathrm{MI}$ and $\mathrm{Pl}$ and their significance for lung DNA adduct levels and cancer risk. Carcinogenesis, 18, 1285-1289.

24. Tang, D.L., Rundle A., Warburton D., Santella R.M., Tsai W.Y., Chiamprasert S., Hsu Y.Z. and Perera F.P. (1998) Associations between both genetic and environmental biomarkers and lung cancer: evidence of a greater risk of lung cancer in women smokers. Carcinogenesis, 19, 1949-1953.

25. Phillips, D.H., Schoket B., Hewer A., Bailey E., Kostic S. and Vincze I. (1990) Influence of cigarette smoking on the levels of DNA adducts in human bronchial epithelium and white blood cells. Int $J$ Cancer, 46, 569-575.

26. Savela, K. and Hemminki K. (1991) DNA adducts in lymphocytes and granulocytes of smokers and nonsmokers detected by the ${ }^{32} \mathrm{P}$-postlabelling assay. Carcinogenesis, 12, 503-508.

27. Van Schooten, F.J., Hillebrand M.J., Van Leeuwen F.E., Van Zandwijk N., Jansen H.M., Den Engelse L. and Kriek E. (1992) Polycyclic aromatic hydrocarbon-DNA adducts in white blood cells from lung cancer patients: no correlation with adduct levels in lung. Carcinogenesis, 13, 987-993.

28. Wiencke, J.K., Kelsey K.T., Varkonyi A., Semey K., Wain J.C., Mark E. and Christiani D.C. (1995) Correlation of DNA adducts in blood mononuclear cells with tobacco carcinogen-induced damage in human lung. Cancer Res, 55, 4910-4914.

29. Godschalk. R.W., Maas L.M., Van Zandwijk N., Van't Veer L.J., Breedijk A., Borm P.J., Verhaert J., Kleinjans J.C. and Van Schooten F.J. (1998) Differences in aromatic-DNA adduct levels between alveolar macrophages and subpopulations of white blood cells from smokers. Carcinogenesis, 19, 819. 825.

30. Sakula, A. (1986) Charcot-Leyden crystals and Curschmann spirals in asthmatic sputum. Thorax, 41, 503-507.

31. Shata, A.M., Coulter J.B., Parry C.M., Ching'ani G., Broadhead R.L. and Hart C.A. (1996) Sputum induction for the diagnosis of tuberculosis. Arch Dis Child, 74, 535-537.

32. Keatings, V.M., Collins P.D., Scott D.M. and Barnes P.J. (1996) Differences in interleukin-8 and tumor necrosis factor-alpha in induced sputum from patients with chronic obstructive pulmonary disease or asthma. Am J Respir Crit Care Med, 153, 530-534.

33. Pavord, I.D., Pizzichini M.M., Pizzichini E. and Hargreave F.E. (1997) The use of induced sputum to investigate airway inflammation. Thorax, 52, 498-501. 
34. Mathis, A., Weber R., Kuster H. and Speich R. (1997) Simplificd sample processing combined with a sensitive one-tube nested PCR assay for detection of Pneumocystis carinii in respiratory specimens. $J$ Clin Microbiol, 35, 1691-1695.

35. Van Schooten, F.J., Godschalk R.W., Breedijk A., Maas L.M., Kriek E., Sakai H., Wigbout G., Baas P., Van't Veer L. and Van Zandwijk N. (1997) ${ }^{32}$ P-postlabclling of aromatic DNA adducts in white blood cells and alveolar macrophages of smokers: saturation at high exposures. Mutat Res, 378, 65-75.

36. Gupta, R.C. (1985) Enhanced sensitivity of ${ }^{32} \mathrm{P}$-postlabeling analysis of aromatic carcinogen:DNA adducts. Cancer Res, 45, 5656-5662.

37. Gershman, N.H., Wong H.H., Liu J.T., Mahlmeister M.J. and Fahy J.V. (1996) Comparison of two methods of collecting induced sputum in asthmatic subjects. Eur Respir J, 9, 2448-2453.

38. Pizzichini, E., Pizzichini M.M., Efthimiadis A., Hargreave F.E. and Dolovich J. (1996) Measurement of inflammatory indices in induced sputum: effects of selection of sputum to minimize salivary contamination. Eur Respir J, 9, $1174-1180$.

39. Popov, T.A., Pizzichini M.M., Pizzichini E., Kolendowicz R., Punthakee Z., Dolovich J. and Hargreave F.E. (1995) Some technical factors influencing the induction of sputum for cell analysis. Eur Respir J, 8, 559-565.

40. Fahy, J.V., Wong H., Liu J. and Boushcy H.A. (1995) Comparison of samples collected by sputum induction and bronchoscopy from asthmatic and healthy subjects. Am $J$ Respir Crit Care Med, 152, 5358.

41. Vagaggini, B., Paggiaro P.L., Giannini D., Franco A.D., Cianchetti S., Carnevali S., Taccola M., Bacci E., Bancalari L., Dentc F.L. and Giuntini C. (1996) Effect of short-term $\mathrm{NO}_{2}$ cxposure on induced sputum in normal, asthmatic and COPD subjects. Eur Respir J, 9, 1852-1857.

42. Kidncy, J.C., Wong A.G., Efthimiadis A., Morris M.M., Sears M.R., Dolovich J. and Hargreave F.E. (1996) Elcvated B cells in sputum of asthmatics. Close correlation with eosinophils. Am J Respir Crit Care Med, 153, 540-544.

43. Keatings, V.M. and Barnes P.J. (1997) Granulocyte activation markers in induced sputum: comparison between chronic obstructive pulmonary disease, asthma, and normal subjects. Am J Respir Crit Care Med, 155, 449-453.

44. Chalmers, G.W., Thomson L., Macleod K.J., Dagg K.D., McGinn B.J., McSharry C., Patel K.R. and Thomson N.C. (1997) Endothelin-I levels in induced sputum samples from asthmatic and normal subjects. Thorax, 52, 625-627.

45. Lensmar, C., Elmberger G., Skold M. and Eklund A. (1998) Smoking alters the phenotype of macrophages in induced sputum. Respir Med, 92, 415-420.

46. Smith. C. and Wood E. (1996) Immunological defense. In Smith, C. and Wood, E. (eds), Cell biology. Chapman \& Hall, London, pp. 423-462.

47. Øvrebø, S., Haugen A., Phillips D.H. and Hewer A. (1992) Detection of polycyclic aromatic hydrocarbon-DNA adducts in white blood cells from coke oven workers: correlation with job categories. Cancer Res, 52, 1510-1514.

48. Simons, A.M., Mugica van Herckenrode C., Rodriguez J.A., Maitland N., Anderson M., Phillips D.H. and Coleman D.V. (1995) Demonstration of smoking-related DNA damage in cervical epithelium and correlation with human papillomavirus type 16, using exfoliated cervical cells. Br J Cancer, 71, 246249.

49. Gupta, R.C. and Earley K. (1988) ${ }^{32}$ P-adduct assay: comparative recoveries of structurally diverse DNA adducts in the various enhancement procedures. Carcinogenesis, 9, 1687-1693. 
50. Gallagher, J.E., Jackson M.A., George M.H., Lewtas J. and Robertson I.G. (1989) Differences in detection of DNA adducts in the ${ }^{32} \mathrm{P}$-postlabelling assay after cither 1-butanol extraction or nuclease $\mathrm{PI}$ treatment. Cancer Lett, 45, 7-12.

51. Izzotti, A., Rossi G.A., Bagnasco M. and De Flora S. (1991) Benzo[alpyrene diolepoxide-DNA adducts in alvcolar macrophages of smokers. Carcinogenesis, 12, 1281-1285.

52. De Flora, S., Izzotti A., D'Agostini F., Rossi G.A. and Balansky R.M. (1993) Pulmonary alveolar macrophages in molecular epidemiology and chemoprevention of cancer. Environ Health Perspect, 99, 249-252.

53. Spencer-Beach, G.G., Beach A.C. and Gupta R.C. (1996) High-resolution anion-exchange and partition thin-layer chromatography for complex mixtures of ${ }^{32}$ P-postlabeled DNA adducts. $J$ Chromarogr $B$ Biomed Appl, 677, 265-273. 


\section{CHAPTER 3}

ADDUCT ANALYSIS IN SPUTUM AND LYMPHOCYTES 


\title{
Comparison between smoking-related DNA adduct analysis in induced sputum and peripheral blood lymphocytes
}

\author{
A. Besarati Nia, L.M. Maas, E.M.C. Brouwer, J.C.S. Kleinjans, F.J. Van Schooten*
}

Department of Health Risk Analysis and Toxicology, Maastricht University, Maastricht, The Netherlands

\begin{abstract}
We investigated the applicability of induced sputum (IS), a non-invasive derivative from the lower respiratory tract, for smoking-related DNA adduct analysis and its comparability to peripheral blood lymphocytes (PBL). Lipophilic-DNA adducts were quantified by the ${ }^{32} \mathrm{P}$ postlabeling assay in IS and PBL of smokers $(n=9)$ with stable smoking status at three time points [one week intervals] and non-smokers $(n=9)$ at one time point. The success rate for sputum induction was $100 \%$ at all time points. There was no significant difference in total cell count, cell viability, squamous cell count and DNA yield between smokers and non-smokers. Within the smokers, there was no significant difference in IS cytology at three time points: overall [mean of three measurements] total cell count, $9.0 \pm 2.4 \times 10^{6}$; cell viability, $77 \pm 4 \%$; squamous cell count, $28 \pm 5 \%$; non-squamous cell count, $72 \pm 4 \%$ [broncho alveolar macrophages, $75 \pm 6 \%$; neutrophils, $17 \pm 3 \%$; bronchoepithelial cells, $7 \pm 2 \%$; lymphocytes, $0.7 \pm 0.2 \%$; methachromatic cells, $0.3 \pm 0.2 \%$ ]. IS DNA yield did not differ significantly over the three time points [overall \{mean of three extractions\} DNA yield, $66 \pm 20 \mu \mathrm{g}$ ]. A typical smoking-associated diagonal radioactive zone was observed in the adduct maps of IS and PBL of all and five smokers, respectively, and of none of the non-smokers. Lipophilic-DNA adduct levels in both IS and PBL of smokers were higher than those of non-smokers $(3.7 \pm 0.9$ versus $0.7 \pm 0.2 / 10^{8} \mathrm{nt}, \mathrm{P}=0.0005$ and $2.1 \pm 0.3$ versus $0.6 \pm 0.1 / 10^{8} \mathrm{nt}, \mathrm{P}=0.0001$, respectively). In smokers the level of adducts in IS was non-significantly higher than that in $\operatorname{PBL}\left(3.7 \pm 0.9\right.$ versus $\left.2.1 \pm 0.3 / 10^{8} \mathrm{nt}, \mathrm{P}=0.1\right)$, whilst in non-smokers the difference was not appreciable $\left(0.7 \pm 0.2\right.$ versus $\left.0.6 \pm 0.1 / 10^{8} \mathrm{nt}\right)$. Within the smokers there was no significant change in the level of adducts over the three time points either in IS or in PBL [coefficient of variations $34 \%$ and $29 \%$, respectively]. Adducts level in IS at each time point was higher than that in PBL, leading to a significantly higher overall [mean of three quantifications] level of adducts in IS than PBL $\left(3.3 \pm 0.2 / 10^{8}\right.$ nt versus $\left.2.1 \pm 0.1 / 10^{8} \mathrm{nt}, \mathrm{P}=0.02\right)$. The overall level of adducts in both IS and PBL were dose-dependently related to smoking indices. We conclude that IS is a preferable matrix as compared to PBL for molecular dosimetry of (current) exposure to inhalatory carcinogens because its analysis reveals both the existence and magnitude of exposure more explicitly.
\end{abstract}

Based on the manuscript published in:

"Carcinogenesis (2000) 21, 1335-1340" 


\section{Chapter Three}

\section{Adduct analysis in sputum and lymphocytes}

\section{INTRODUCTION}

Todate, DNA adducts are known as biologically effective dose markers of exposure to carcinogens as well as potential markers of cancer susceptibility $(1,2)$. So far, DNA adduct analysis has been performed in various biological matrices, of which peripheral blood lymphocytes (PBL) are the most utilized (3-6). Owing to their accessibility in a relatively noninvasive fashion and their capability of reflecting DNA adduct formation consequent to exposure to carcinogens, PBL have been used in numerous investigations (3-7). However, as circulating blood cells, PBL are subject to various routes of exposure to carcinogens, e.g., ingestion, inhalation and absorption. Thus, PBL represent the integrated DNA adduct burden for the entire body but not for an individual organ (8). This throws doubt upon their validity as a surrogate for those organs, which are solely exposed to specific carcinogens via particular routes, e.g., the lung (9-13).

As part of our ongoing project to identify innovative biological materials that can serve for biomonitoring of putatively exposed humans, we have embarked on research on induced sputum (IS), a non-invasively obtainable matrix from the lower respiratory tract. Thus far, we have reported the applicability of IS for molecular dosimetry of exposure to inhalatory carcinogens (14) by demonstrating significantly higher levels of smoking-related DNA adducts in IS of smokers as compared to non-smokers. Here, we validate our previous findings and make a comparison between DNA adduct analysis in IS and PBL. Further, we assess the consistency of DNA adduct analysis at the intra-individual level in IS as well as in PBL. To achieve these objectives, we quantify lipophilic-DNA adducts in IS and PBL of a group of smokers with stable smoking status at three consecutive time points by means of the nuclease P1 (NP1) enhanced ${ }^{32} \mathrm{P}$-postlabeling assay. For comparison purpose, we also measure the respective level of adducts in IS and PBL of a control group of non-smokers at time point 1 .

\section{MATERIAL AND METHODS}

\section{Study Population}

Healthy smoking and non-smoking volunteers who participated in our previous study (14) were re-recruited [one participant who had quit smoking since then was also included and considered as an ex-smoker]. Characteristics of the study population are listed in Table I. The study population consisted of a group of smokers $(n=9)$ with an average age of $38 \pm 5$ years and a group of lifelong non-smokers $(n=9)$ aged $34 \pm 3$ years. Prior to sampling, all participants were interviewed to re-check their available database and briefed for the study 
protocol; they were advised to maintain strictly their lifestyles, particularly smoking behaviors and dietary intakes, throughout the study. Smoking status was evaluated using current smoking indices [number of cigarettes smoked per day and amount of tar consumed per day] and smoking history index [pack years]. Tar consumption per day was calculated as the number of cigarettes smoked per day multiplied by the tar content [mg] of the cigarette. Pack years was estimated as the number of cigarettes smoked per day divided by twenty and multiplied by the smoking years. As the smoking status of most participants had changed since the previous study, we could not use the then obtained data [as time point 1 data] for comparison purposes. The study outline was three consecutive samplings of blood and sputum at intervals of one week in the smoking group, and a single sampling of blood and sputum in the non-smoking group. The study protocol was approved by the Medical Ethical Commission of Maastricht University.

\section{Peripheral Blood}

Twenty $\mathrm{ml}$ of venous blood was drawn into heparinized Venoject ${ }^{\circ} \Pi$ tubes (Terumo Europe N.V., Leuven, Belgium). Lymphocyte isolation was done according to the method of Bøyum (15) by gradient centrifugation of the samples over Lymphoprep ${ }^{\mathrm{TM}}$ (Nycomed Pharma, Oslo, Norway). Isolated lymphocytes were pelleted and preserved at $-80^{\circ} \mathrm{C}$ until DNA isolation.

Table I. Characteristics of the study population

\begin{tabular}{|l||c||c|}
\hline & Smokers & Non-smokers \\
\hline \hline Number & 9 & 9 \\
\hline Gender (male/female) & $6 / 3$ & $3 / 6$ \\
\hline Age & $38 \pm 5$ & $34 \pm 3$ \\
\hline Cigarettes/day & $15 \pm 3$ & 0 \\
\hline Tar/day (mg) & $280 \pm 83$ & 0 \\
\hline Smoking years & $20 \pm 5$ & 0 \\
\hline Pack years & $18 \pm 6$ & 0 \\
\hline
\end{tabular}

Results are expressed as means \pm SEM 


\section{Induced Sputum}

Induction of sputum and processing of the samples were done as described earlier (14). Briefly, after pretreatment with inhalatory salbutamol [200 $\mu \mathrm{g}$ ], subjects inhaled ultrasonically nebulized $4.5 \%$ saline delivered from an Ultra-Neb ${ }^{T M} 2000$ (De Vilbiss, Somerset, PA) for a period of up to $21 \mathrm{~min}$. There were three 5-min intervals at the end of each 7-min inhalation period. During the intervals, subjects rinsed their mouths, gargled and then, coughed up the produced expectorate into a 50-ml Greiner tube (Greiner Labortechnik, Frickenhausen, Germany) placed on ice. Additionally, they were instructed to cough up the available expectorate at any moment irrespective of the time of induction. Induction was terminated at the end of $21 \mathrm{~min}$ of inhalation, or as soon as a sufficient amount of sputum [5 ml] was obtained. IS samples were processed by adding $0.1 \%$ Sputolysine (Calbiochem-Novabiochem Corp., La Jolla, CA) [equal to 4 volumes of the samples], followed by incubation in a shaking water bath for $15 \mathrm{~min}$ at $37^{\circ} \mathrm{C}$. The samples were intermittently vortexed for $15 \mathrm{sec}$ and aspirated with a $25-\mathrm{ml}$ pipette. To quench the activity of the Sputolysine, 4 volumes of phosphate buffered saline (PBS), pH 7.4 were added and incubation went by for another 5 min. The resulting homogenates were centrifuged at $725 \times \mathrm{g}$ for $10 \mathrm{~min}$ at $4^{\circ} \mathrm{C}$. Supernatants were discarded and the pellets were resuspended in $2 \mathrm{ml}$ PBS from which $100 \mu \mathrm{l}$ aliquots were used for cytological examination and the reminders were re-pelleted to be preserved at $80^{\circ} \mathrm{C}$ until DNA isolation. Determinations of cell viability [according to the trypan blue exclusion technique] and total cell counts were carried out using $10 \mu \mathrm{l}$ of the cell suspensions in a standardized haemocytometer. From the remaining cell suspensions, aliquots of $30 \times 10^{3}$ cells (diluted in PBS to a final volume of $300 \mu \mathrm{l}$ ) were cytocentrifuged (Shandon ${ }^{\circledR}$, Cheshire, UK) at $1500 \mathrm{rpm}$ for $5 \mathrm{~min}$ onto Polysine ${ }^{\mathrm{TM}}$ microslides (E. Merck Nederland B.V., Amsterdam, the Netherlands). The slides were stained with May-Grünwald Giemsa and cell differentiation was done by counting 500 non-squamous cells per slide.

\section{DNA Isolation}

The DNA contents of both IS and PBL were isolated as described earlier (14). Briefly, cell pellets were thawed and then, lysed with $400 \mu \mathrm{l}$. SET/SDS $100 \mathrm{mM} \mathrm{NaCl}, 20 \mathrm{mM}$ EDTA, 50 $\mathrm{mM}$ Tris, $0.5 \%$ sodium dodecyl sulfate, $\mathrm{pH} 8.0]$ at $37^{\circ} \mathrm{C}$, overnight. The resulting suspensions were treated with $50 \mu \mathrm{l}$ RNAse mixture $[0.1 \mathrm{mg} / \mathrm{ml}$ RNAse $A$ and $1000 \mathrm{U} / \mathrm{ml}$ RNAse T1] for $3 \mathrm{~h}$ at $37^{\circ} \mathrm{C}$, followed by treatment with $75 \mu \mathrm{l}$ Proteinase $\mathrm{K}[10 \mathrm{mg} / \mathrm{ml}]$ for $2 \mathrm{~h}$ at $37^{\circ} \mathrm{C}$. DNA was isolated by repetitive extraction with phenol/chloroform/isoamyl alcohol [25:24:1] and chloroform/isoamyl alcohol [24:1] and subsequently, precipitated with 2 volumes of $100 \%$ cold ethanol and $1 / 30$ volume of $3 \mathrm{M}$ sodium acetate, $\mathrm{pH}$ 5.3. Precipitated DNA was rinsed with 70\% ethanol and dissolved in $2 \mathrm{mM}$ Tris, $\mathrm{pH} 7.4$. The purity and concentration of DNA were determined spectrophotometrically $\left[\mathrm{A}_{230 / 200}: \sim 0.43, \mathrm{~A}_{260 / 280}: \sim 1.8\right]$ and afterwards, its concentration was adjusted to $2 \mathrm{mg} / \mathrm{ml}$. 


\section{${ }^{32}$ P-postlabeling Assay}

The ${ }^{32} \mathrm{P}$-postlabeling assay was performed as described earlier (14). Briefly, $10 \mu \mathrm{g}$ of DNA was digested to deoxyribonucleoside 3'-monophosphates using calf spleen phosphodiesterase $[2 \mu \mathrm{g} / \mu \mathrm{l}]$ and micrococcal endonuclease $[0.25 \mathrm{U} / \mu \mathrm{l}]$. Half of the digest was treated with NP1 [2.5 $\mathrm{g} / \mu \mathrm{l}]$ and subsequently, labeled with $\left[\gamma^{32} \mathrm{P}\right]-\mathrm{ATP}$ in the presence of T4-polynucleotide kinase. Radiolabeled adducted nucleotide biphosphates were separated by two-dimensional chromatography on polyethyleneimine (PEI) -cellulose sheets (Macherey Nagel, Düren, Germany) using the following solvent systems: $\mathrm{D}_{1}, 1 \mathrm{M} \mathrm{NaH_{2 }} \mathrm{PO}_{4}, \mathrm{pH} 6.5 ; \mathrm{D}_{2}, 8.5 \mathrm{M}$ Urea, 5.3 M Lithiumformate, $\mathrm{pH} 3.5 ; \mathrm{D}_{3}, 1.2 \mathrm{M}$ Lithiumchloride, $0.5 \mathrm{M}$ Tris, 8.5 Urea, $\mathrm{pH} 8.0$, and $\mathrm{D}_{4}, 1.7 \mathrm{M} \mathrm{NaH}_{2} \mathrm{PO}_{4}, \mathrm{pH} 6.0$. To ensure the efficiency of NP1 treatment and ATP excess, an aliquot of the digest was one-dimensionally chromatographed on PEI-cellulose sheet (Merck, Darmstadt, Germany) using a solvent system of $0.12 \mathrm{M} \mathrm{NaH}_{2} \mathrm{PO}_{4}, \mathrm{pH}$ 6.8. For quantification purposes, 2 standards of $\left[{ }^{3} \mathrm{H}\right] \mathrm{BPDE}$ modified $\left[1\right.$ adduct per $10^{7}$ and $10^{8}$ unmodified nucleotides] were parallelly run in all experiments. Quantification was performed using a phosphor imager (Molecular Dynamics ${ }^{\mathrm{TM}}$, Sunnyvale, CA). Quantitatively, half of the detection limit for diagonal radioactive zone (DRZ) $\left[0.25\right.$ adducts per $10^{8}$ nucleotides] was considered as the determined level of adducts for samples which showed neither a DRZ nor an adduct spot in their adduct maps. Nucleotides quantification was done by labeling the remaining half of the digested DNA with $\left[\gamma^{32} \mathrm{P}\right]$-ATP in the presence of T4-polynucleotide kinase, followed by one-dimensional chromatography on PEI-cellulose sheet using a solvent system of $0.12 \mathrm{M} \mathrm{NaH}_{2} \mathrm{PO}_{4}, \mathrm{pH} 6.8$.

\section{Statistical Analysis}

Results were expressed as mean \pm standard error of the mean throughout. The MannWhitney $U$ test was used to make a comparison between smokers and non-smokers for all variables in both IS and PBL at time point one. The Friedman's two way analysis of variance was performed to assess the intra-individual variations of all variables over time in both IS and PBL of smokers; coefficient of variation (CV) together with $95 \%$ confidence interval $195 \%$ $\mathrm{CI}$ ) are given as the indicators of variability. Also, the Wilcoxon signed rank test was used to compare the mean of each variable [at three time points] in IS with its respective in PBL. The Kendall's rank correlation was utilized to study the relationships between different variables. The ex-smoker was excluded from all analyses. Statistical significance was considered at $\mathrm{P}<$ 0.05 . 


\section{RESULTS}

\section{Success Rate for Sputum Induction}

Sputum induction was $100 \%$ successful as all subjects well tolerated the procedure, did not experience any troublesome symptoms throughout and produced sufficient amounts of sputum for further analysis.

\section{Cytological Examinations and DNA Yield}

Cellular characteristics and DNA yields of IS are presented in Table II. At time point 1 , there was no significant difference in total cell count, cell viability and squamous cell count between smokers and non-smokers $\left(6.5 \pm 1.6\right.$ versus $7.4 \pm 2.8 \times 10^{6}, \mathrm{P}=0.7,74 \pm 7$ versus $61 \pm 8 \%$, $\mathrm{P}=0.2$ and $31 \pm 8$ versus $24 \pm 8 \% \mathrm{P}=0.4$, respectively). With respect to non-squamous cell differentials, smokers had significantly higher percentage of neutrophils and lower percentage of bronchoalveolar macrophages as compared to non-smokers $(19 \pm 14$ versus $5 \pm 2 \%, \mathrm{P}=$ 0.03 and $71 \pm 8$ versus $92 \pm 2 \%, \mathrm{P}=0.001$, respectively). There was no significant difference in DNA yield between smokers and non-smokers $(39 \pm 10 \mu \mathrm{g}$ versus $46 \pm 14 \mu \mathrm{g}, \mathrm{P}=0.8)$. In both smokers and non-smokers DNA yields were related to total cell counts $(r=0.5, P=0.08$ and $\mathrm{r}=0.7, \mathrm{P}=0.01$, respectively).

Table II. Cellular characteristics and DNA yicld of IS of smokers and non-smokers

\begin{tabular}{|l||c|c|c||c|}
\hline & $\begin{array}{c}\text { Time point 1 } \\
(n=8)\end{array}$ & $\begin{array}{c}\text { Time point 2 } \\
(\mathrm{n}=8)\end{array}$ & $\begin{array}{c}\text { Time point 3 } \\
(\mathrm{n}=8)\end{array}$ & $\begin{array}{c}\text { Mean of Time } \\
\text { point } 1-3\end{array}$ \\
\hline Total cell count $\left(\times 10^{\prime \prime}\right)$ & $6.5 \pm 1.6$ & $9.3 \pm 3.4$ & $11.0 \pm 3.5$ & $9.0 \pm 2.4$ \\
\hline Viability \% & $74 \pm 7$ & $74 \pm 5$ & $83 \pm 3$ & $77 \pm 4$ \\
\hline Squamous cells \% & $31 \pm 8$ & $26 \pm 5$ & $27 \pm 7$ & $28 \pm 5$ \\
\hline Non-squamous cells \% & $69 \pm 7$ & $74 \pm 10$ & $73 \pm 6$ & $72 \pm 4$ \\
\hline Bronchoalvcolar macrophages \% & $71 \pm 8^{*}$ & $79 \pm 5$ & $75 \pm 12$ & $75 \pm 6$ \\
\hline Neutrophils \% & $19 \pm 14^{n}$ & $17 \pm 8$ & $15 \pm 9$ & $17 \pm 3$ \\
\hline Bronchoepithelial cells \% & $9 \pm 4$ & $3 \pm 5$ & $9 \pm 3$ & $7 \pm 2$ \\
\hline Lymphocytcs \% & $0.7 \pm 0.5$ & $0.8 \pm 0.4$ & $0.6 \pm 0.5$ & $0.7 \pm 0.2$ \\
\hline Methachromatic cells \% & $0.3 \pm 0.6$ & $0.2 \pm 0.3$ & $0.4 \pm 0.6$ & $0.3 \pm 0.2$ \\
\hline DNA yield $(\mu \mathrm{g})$ & $39 \pm 10$ & $54 \pm 17$ & $91 \pm 38$ & $66 \pm 20$ \\
\hline
\end{tabular}

Results are expressed as means \pm SEM.

"Statistically significant as compared to non-smokers at time point $1, P=0.001$.

'Statistically significant as compared to non-smokers at time point $1, P=0.03$. 
Within the smokers there was no significant difference in total cell count, cell viability and cell differentials over the three time points [Tab. II]; coefficients of variation in total cell count, cell viability, squamous cell and non-squamous cell counts were $45 \%$ [95\% Cl $28-61], 15 \%$ [95\% CI 6-24], 18\% [95\% CI $11-25]$ and 24\% [95\% CI $9-31$ ], respectively, and overall [mean of three measurements] total cell count, cell viability, squamous cell and non-squamous cell counts were $9.0 \pm 2.4 \times 10^{6}, 77 \pm 4 \%, 28 \pm 5 \%$ and $72 \pm 4 \%$, respectively. The overall non-squamous cell differential was as follows, bronchoalveolar macrophages (BAM), $75 \pm$ $6 \%$; neutrophils, $17 \pm 3 \%$; bronchoepithelial cells, $7 \pm 2 \%$; lymphocytes, $0.7 \pm 0.2 \%$; methachromatic cells, $0.3 \pm 0.2 \%$. Furthermore, there was no significant change in DNA yield over the three time points (CV 42\% [95\% CI 20 - 65]); overall [mean of three extractions] DNA yield was $66 \pm 20 \mu \mathrm{g}$. Also, DNA yield at each time point was related to the respective total cell count $\left(r_{1}=0.5, P_{1}=0.08, r_{2}=0.6, P_{2}=0.04, r_{3}=0.6, P_{3}=0.04\right)$, resulting in a significant relationship between the overall DNA yield and the overall total cell count $(r=0.6$, $\mathrm{P}=0.03$ ).

\section{${ }^{32}$ P-postlabeling of Lipophilic-DNA Adducts}

At time point 1, a typical smoking-associated DRZ was observed in the adduct maps of IS of all smokers [not the ex-smoker]. However, the DRZ was only present in the adduct maps of PBL of five smokers. In non-smokers, no DRZ could be seen in the adduct maps of either IS or PBL [Fig. 1].

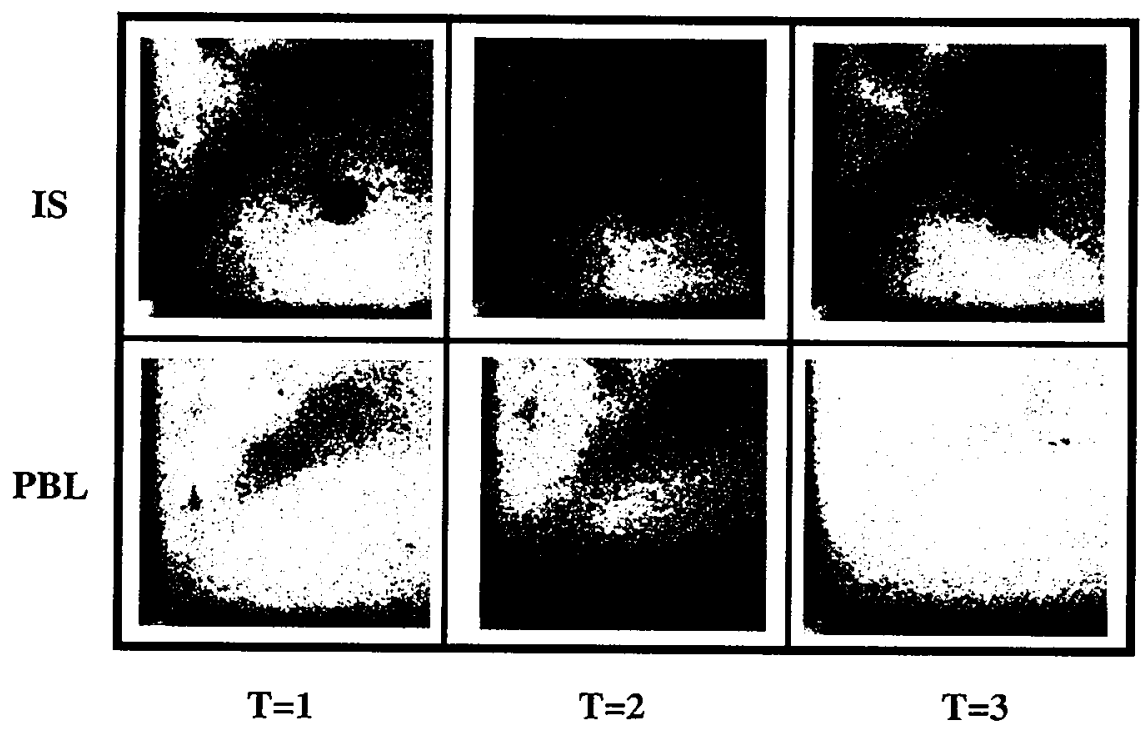

Fig. 1. Representative chromatograms of the ${ }^{32} \mathrm{P}$-postlabelled DNA adducts in induced sputum (IS) and in peripheral blood lymphocytes (PBL) of a smoker at three time points, $T=1$, time point $1, T=2$, time point 2 , $T=3$, time point 3 . 
Quantitatively, smokers had significantly higher levels of lipophilic-DNA adducts in both IS and PBL as compared to non-smokers $\left(3.7 \pm 0.9\right.$ versus $0.7 \pm 0.2 / 10^{8} \mathrm{nt}, \mathrm{P}=0.0005$ and 2.1 \pm 0.3 versus $0.6 \pm 0.1 / 10^{8} \mathrm{nt}, \mathrm{P}=0.0001$ ). Adduct levels in smokers ranged from $1.4 / 10^{8}$ to $7.1 / 10^{8}$ nucleotides in IS and from $1.3 / 10^{8}$ to $2.9 / 10^{8}$ nucleotides in PBL. The levels of adducts in non-smokers varied in the ranges of $0.25-1.6 / 10^{8}$ nucleotides in IS and $0.25-$ $1.2 / 10^{8}$ nucleotides in PBL. In smokers the levels of adducts in IS were non-significantly higher than those in PBL ( $3.7 \pm 0.9$ versus $2.1 \pm 0.3 / 10^{8} \mathrm{nt}, \mathrm{P}=0.1$ ); however, in nonsmokers the difference was far less pronounced $\left(0.7 \pm 0.2\right.$ versus $\left.0.6 \pm 0.1 / 10^{8} \mathrm{nt}\right)$. Only in smokers was there a significant correlation between the level of adducts in IS and PBL $(r=0.8$, $\mathrm{P}=0.05$ ). Within the smokers there was a DRZ in the adduct maps of IS of all individuals [not the ex-smoker] at all time points. The DRZ was only present in the adduct maps of PBL of five individuals $(62.5 \%)$ at all time points [irrespective of the smoking status] [Fig. 1].

Neither in IS nor in PBL, did lipophilic-DNA adduct levels change significantly over the three time points (CV 34\% [95\% CI 20 - 49] and CV 29\% [95\% CI 3 - 55], respectively) [Fig. 2]; the levels of adducts in IS at each time point were higher than those in PBL (IS $1.3: 3.7$ $\left.\pm 0.9 / 10^{8} \mathrm{nt}, 3.4 \pm 0.4 / 10^{8} \mathrm{nt}, 3.1 \pm 0.5 / 10^{8} \mathrm{nt}\right),\left(\mathrm{PBL}_{1.3}: 2.1 \pm 0.3 / 10^{8} \mathrm{nt}, 2.3 \pm 0.8 / 10^{8} \mathrm{nt}, 1.9\right.$ $\pm 0.6 / 10^{8} \mathrm{nt}$ ), leading to a significantly higher overall [mean of three quantifications] level of adducts in IS than PBL (3.3 $\pm 0.2 / 10^{8}$ nt versus $\left.2.1 \pm 0.1 / 10^{8} \mathrm{nt}, \mathrm{P}=0.02\right)$ [Fig. 3].

IS

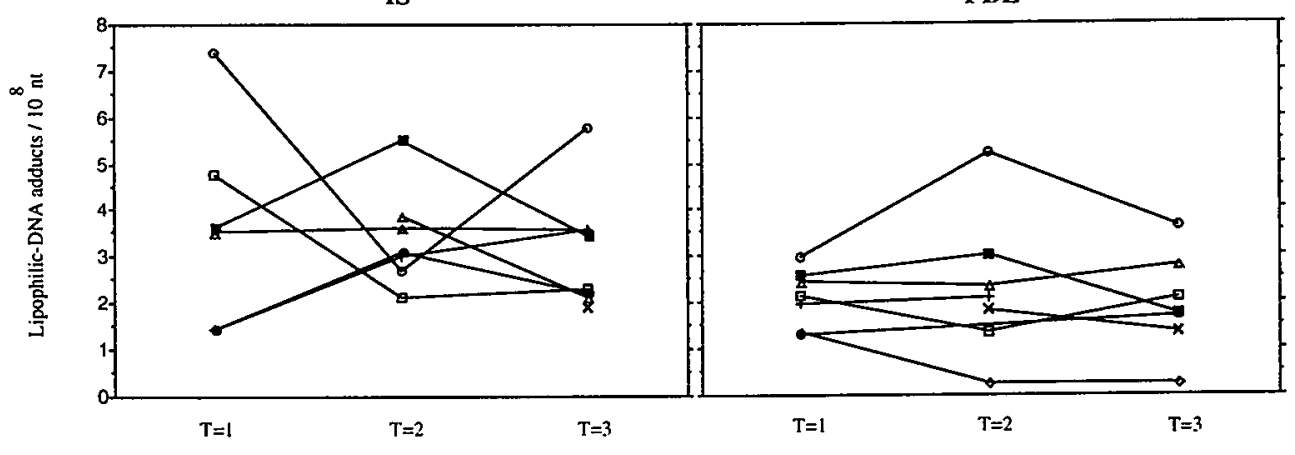

Fig.2. Intra-individual variation in lipophilic-DNA adduct levels in induced sputum (IS) and peripheral blood lymphocytes (PBL) of smokers. $T=1$, time point $1, T=2$, time point $2, T=3$, time point 3 . 
The overall level of adducts ranged from 2.0 to $5.0 / 10^{8}$ nucleotides in IS, and from 0.9 to $3.5 / 10^{8}$ nucleotides in PBL [Fig. 3]. Unlike at time point 1 , at the other two time points, there was no significant relation between the level of adducts in IS and the respective level in PBL $\left(r_{2}=0.4, P_{2}=0.3, r_{3}=0.5, P_{3}=0.2\right)$. Nevertheless, the overall level of adducts [mean of three measurements] in IS was significantly related to that in PBL $(r=0.6, P=0.05)$. There were dose-response relationships between the overall levels of adducts in IS and current smoking indices (cigarettes/day, $r=0.6, P=0.02$, tar/day, $r=0.6, P=0.05$ ). The overall level of adducts in PBL was dose-dependently related to both current smoking indices (tar/day, $r=0.7, P=$ 0.02 , cigarettes/day, $\mathrm{r}=0.6, \mathrm{P}=0.05$ ) and cumulative smoking index (pack years, $\mathrm{r}=0.8, \mathrm{P}=$ 0.05 , adjusted for tar/day).

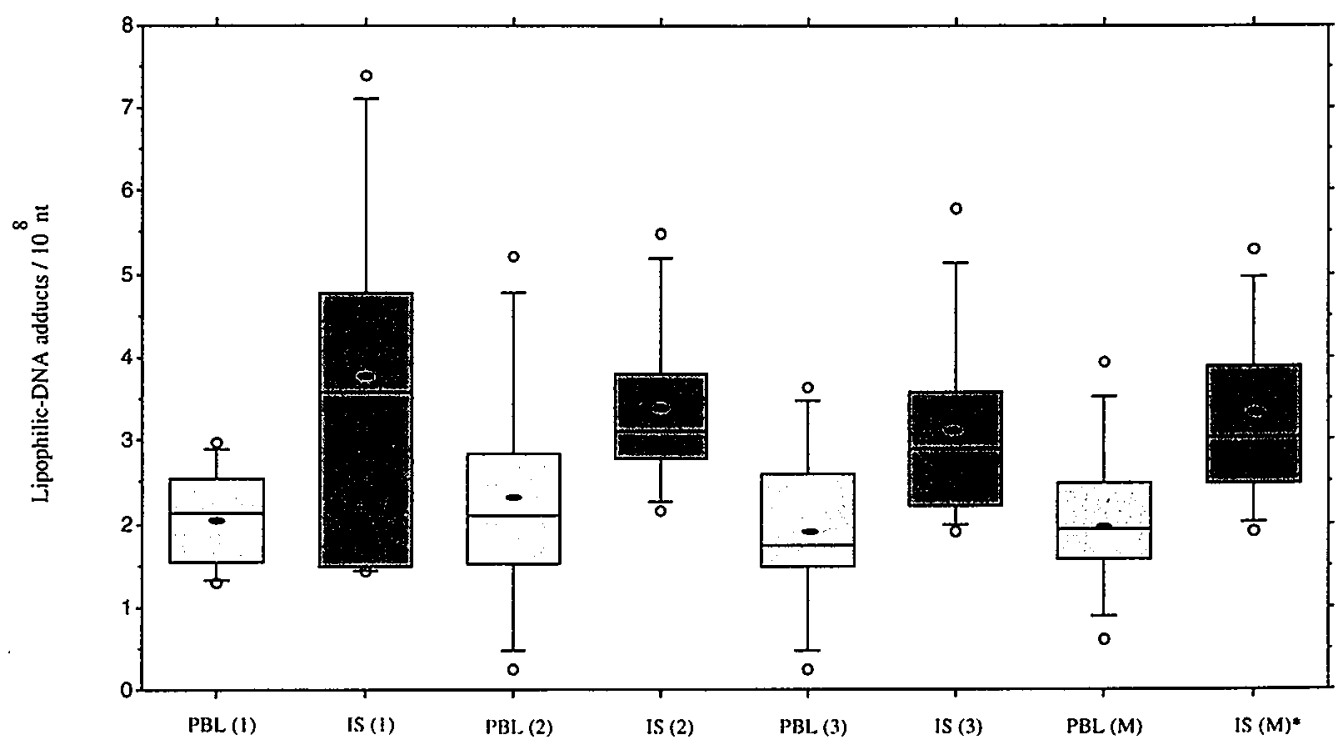

Fig. 3. Lipophilic-DNA adduct levels in induced sputum (IS) and peripheral blood lymphocytcs (PBL) of smokers and non-smokers over time. The numbers inside the brackets, the time points. $I S(M)$ and $P B L(M)$, the mean (of three time points) of adduct levels in IS and PBL, respectively. The lower and upper edges of the boxes, the $25^{\text {th }}$ and the $75^{\text {th }}$ percentiles, respectively. $o$ and within the boxes, the means and the medians, respectively. Lower and upper bars, the $10^{\text {th }}$ and the $90^{\text {th }}$ percentiles, respeclively. 0 , Individual values $<10^{\text {th }}$ or $>90^{\text {th }}$ percentiles.

'Statistically significant as compared to non-smokers' PBL (1), $\mathrm{P}=0.0005$.

'Statistically significant as compared to non-smokers' IS (1), P=0.0001.

'Statistically significant as compared to smokers' PBL (M), $P=0.02$. 


\section{DISCUSSION}

The absolute success rate for sputum induction and the consistency in cytological examination of IS shown in this study confirmed our previous observation that sputum induction is a feasible, reproducible and reliable technique for sampling lower respiratory tract of healthy volunteers (14). Analogously, we found a balance between neutrophil and BAM percentages in both smokers and non-smokers. In addition, we observed significantly higher percentage of neutrophils and lower percentage of BAM in smokers as compared to non-smokers (14). The latter could be a manifestation of smoking-induced inflammation in the airway wherein neutrophils function as the first line of inflammatory cells $(14,16,17)$. We have also noticed that individuals who repeatedly undergo sputum induction, are more likely to produce genuine sputum with low salivary contamination and high cellularity. Apparently, these individuals learn over time how to cope with the induction procedure. In fact, the higher cellularity of IS samples at time points 2 and 3 , which was in line with the greater DNA yield at the respective times, could explain the intra-individual variation in DNA yield of IS in smokers.

Our lipophilic-DNA adduct analysis in IS of smokers and non-smokers was in good agreement with that of our previous report (14), reaffirming the applicability of IS for molecular dosimetry of exposure to inhalatory carcinogens. Similar to that report, we found a DRZ, the indicator of exposure to complex mixture of chemical carcinogens e.g., tobacco smoke $(18,19)$, in the adduct maps of IS of all smokers and none of the non-smokers. Furthermore, we observed significantly higher level of adducts [ 5.3 fold] in IS of smokers as compared to non-smokers (14). Noteworthily, these comparative findings in IS were more striking than their respectives in PBL. Indeed, there was only a DRZ in the adduct maps of PBL of five of the smokers and the level of adducts in the PBL of smokers was 3.5-fold higher than that of non-smokers. It should be noted that as most of the non-smokers had hardly any detectable adducts either in IS or in PBL, we excluded this group of individuals from the repeated measurement.

In repeated measurements of lipophilic-DNA adducts in IS and PBL of smokers, we observed an intra-individual stability in DNA adduct analysis in IS as well as in PBL. This gives rise to the idea that single quantification of adducts in both matrices is valid for at least a short period of time as long as the exposure variable remains constant. Moreover, we found a DRZ in the adduct maps of IS of all individuals and of PBL of only $62.5 \%$ [five out of eight] of them at all time points. The discrepancy in DRZ manifestation between these two matrices could be due to the lower and indirect exposure of PBL to inhalatory carcinogens. In addition, the two matrices are composed of different cell types with varying activation/deactivation and DNA repair capacities (20-23). The absence of DRZ in the adduct map of IS of the ex-smoker [smoking cessation, a year ago] was not unexpected. The fact is that IS is mainly composed of short-lived cells with a life span of hours to days (24-26). Therefore, it is conceivable that this matrix may reflect an acute rather than a chronic exposure to carcinogens.

Also, we quantified an elevated level of DNA adducts in IS as compared to PBL at each time point, leading to a 1.6-fold higher overall level of adducts in IS than PBL. These comparative findings in smokers together with the above-mentioned findings in smokers versus non-smokers are of importance. In fact, the ultimate goal of analyzing DNA adducts in small-scale studies like this one is to verify its applicability for exposure assessment in the 
general population (27). Technically, this analysis should be performed in a biological material where both the existence and magnitude of exposure can manifest explicitly. This would be of most importance when the population under investigation is passively exposed to low levels of environmental and/or occupational DNA adduct-inducing agents. Altogether, our data are in favor of the preferability of IS to PBL for such analysis because for a given exposure, formation of DNA adducts in IS is more readily distinguishable than that in PBL. Hence, we may consider IS as a suitable matrix to be used for biomonitoring of exposure to inhalatory carcinogens.

As mentioned earlier, there was an ex-smoker in our study population whose IS adduct map did not reveal any DRZ. Going through this individual's quantitative data, we noticed that the overall level of adducts in her IS had drastically decreased since smoking cessation [from 5.0 to $1.9 / 10^{8}$ nucleotides]. In fact, her overall adduct level had returned almost to the nonsmokers' range that was established in the present study as well as a previous one (14). However, she had an overall adduct level of $1.6 / 10^{8}$ nucleotides in her PBL, which was still within the smokers' range $\left[0.9-3.5 / 10^{8}\right.$ nucleotides]. This could imply the persistence of adducts in PBL, which have a life span of several years (28). The determined level of adducts in this ex-smokers' IS could be considered as a background level of adducts, and attributed to environmental exposure to carcinogenic compounds (29).

Lastly, there were dose-response relationships between the overall level of adducts in IS and current smoking indices indicated by the number of cigarettes smoked per day and the amount of tar consumed per day. On the other hand, the overall level of adducts in PBL was not only dose-dependently related to current smoking indices but also to cumulative smoking index [pack years]. Although one might argue the validity of these indices as compared to the internal dose markers e.g., urinary cotinine (30), their reliability upon administration of a standardized questionnaire has already been verified (31-33). Apart from this, the herein doseresponse relationships reiterate the implication that formation of DNA adducts in IS and PBL reflect acute and chronic exposure, respectively, to carcinogens.

In summary, we conclude that IS is a choice of preference for molecular dosimetry of (current) exposure to inhalatory carcinogens because both the existence and magnitude of exposure can be unequivocally determined by its analysis. Prospectively, IS can be of value in intervention studies where modulation of DNA damage is to be investigated through measurement of the biomarkers of interest. 


\section{REFERENCE}

1. Hemminki. K. (1993) DNA adducts, mutations and cancer. Carcinogenesis, 14, 2007-2012.

2. Poiricr, M.C. and Weston, A. (1996) Human DNA adduct measurements: state of the art. Environ Hlth Perspect., 104, 883-893.

3. Santella, R.M. (1991) DNA adducts in humans as biomarkers of exposure to environmental and occupational carcinogens. Environ Carc Rev, C9, 57-81.

4. Farmer, P.B., Sepai, O., Lawrence, R., Autrup, H., Sabro-Nielsen, P., Vestergard, A.B., Waters, R., Leuratt, C., Jones, N.J., Stone. J., Baan, R.A., Van Delft, J.H., Steenwinkel, M.J., Kyrtopoulos, S.A., Souliotis, V.L., Theodorakopoulos, N., Bacalis, N.C., Natarajan. A.T., Tates, A.D., Haugen, A., Andreassen, A., Øvrebø, S., Shuker, D.E., Amaning, K.S. and Castelain, P. (1996) Biomonitoring human exposure to environmental carcinogenic chemicals. Mutagenesis, 11, 363-38I.

5. Kriek, E., Rojas, M., Alexandrov, K. and Bartsch, H. (1998) Polycyclic aromatic hydrocarbon-DNA adducts in human: relevance as biomarkers for exposure and cancer risk. Murat Res, 400, 215-231.

6. Van Delf, J.H., Baan, R.A. and Roza, L. (1998) Biological effect markers for exposurc to carcinogenic compounds and their relevance for risk assessment. Crit Rev Toxicol, 28, 477-510.

7. Nesnow, S., Ross, J., Nelson, G., Holden, K., Erexson, G., Kligerman, A. and Gupta, R.C. (1993) Quantitative and temporal relationships between DNA adduct formation in target and surrogate tissues: implications for biomonitoring. Environ Hlth Perspect, 101 Supp 1, 37-42.

8. Eder, E. (1999) Intraindividual variations of DNA adduct levels in humans. Mutat Res, 424, 249-261.

9. Lewlas, J., Mumford, J., Everson, R.B., Hulka, B., Wilcosky, T., Kozumbo, W., Thompson, C., George, M., Dobias, L. and Sram, R. (1993) Comparison of DNA adducts from exposure to complex mixtures in various human tissues and experimental systems. Environ Hlth Perspect, 99. 89-97.

10. Mustonen, R., Schoket, B. and Hemminki, K. (1993) Smoking-rclated DNA adducts: ${ }^{32}$ P-postlabeling analysis of 7-methylguaninc in human bronchial and lymphocyte DNA. Carcinogenesis, 14, 151-154.

11. Yang. K., Fang, J.L. and Hemminki, K. (1998) Abundant lipophilic DNA adducts in human tissues. Mutat Res, 422, 285-295.

12. Shinozaki, R., Inoue, S. and Choi, K.S. (1998) Flow cytometric measurement of benzolalpyrene-diolepoxide-DNA adducts in normal human peripheral lymphocytes and cultured human lung cancer cells. Cytometry, 31, 300-306.

13. Zhao, C., Tyndyk, M., Eide, 1. and Hemminki, K. (1999) Endogenous and background DNA adducts by methylating and 2-hydroxyethylating agents. Mutat Res, 424, 117-125.

14. Nia, A.B, Maas, L.M.. Van Breda, S.G.J., Curfs, D.M.J., Kleinjans, J.C.S., Wouters, E.F.M. and Van Schooten, F.J. (2000) Applicability of induced sputum for molecular dosimetry of exposure to inhalatory carcinogens: ${ }^{32}$ P-postlabeling of lipophilic-DNA adducts in smokers and non-smokers. Cancer Epidemiol Biomarkers Prev, 9, 367-372.

15. Bøyum, A. (1976) Isolation of lymphocytes, granulocytes and macrophages. Scand J Immunol, 5, 9-15.

16. Smith, C., and Wood, E. (1996) Immunological defence. In: Smith, C., and Wood (eds.) Cell Biology. Chapman \& Hall, London, pp. 423-262.

17. Jimenez Ruiz, C.A., Rajas, O., Ruiz, A., Ramos, A., Florez, S., Ramos, L., Solano, S. and Fornies, E. (1998) Bronchoalveolar lavage in smokers: quantification of alvcolar macrophages and neutrophils as markers of bronchial obstruction. In Vivo, 12, 427-430. 
18. Øvrebø, S., Haugen, A., Phillips, D.H. and Hewer, A. (1992) Detection of polycyclic aromatic hydrocarbon-DNA adducts in white blood cells from coke oven workers: correlation with job categories. Cancer Res, 52, 1510-1514.

19. Simons, A.M., Van Herckenrode, C.M., Rodriguez, J.A., Maitland, N., Anderson, M., Phillips, D.H. and Coleman, D.V. (1995) Demonstration of smoking-related DNA damage in cervical epithelium and correlation with human papillomavirus type 16, using exfoliated cervical cells. $\mathrm{Br} J$ Cancer, 71, 246249.

20. Okano, P., Miller, H.N., Robinson, R.C. and Gelboin, H.V. (1979) Comparison of benzo[a]pyrene and (-)-trans-7,8-dihydroxy-7,8-dihydrobenzo[a]pyrene metabolism in human blood monocytes and lymphocytes. Cancer Res, 39, 3184-3193.

21. Knudsen, L.E., Ryder, L.P. and Wasserman, K. (1992) Induction of DNA repair synthesis in human monocytes/B-lymphocytes compared with T-lymphocyles after exposurc to $\mathrm{N}$-acetoxy- $\mathrm{N}$ acctylaminofluorene and dimethylsulfate in vitro. Carcinogenesis, 13, 1285-1287.

22. Wei, Q. and Spitz, M.R. (1997) The role of DNA repair in susceptibility to lung cancer. Cancer Metastasis Rev, 16, 295-307.

23. Butkicwicz, D., Grzybowska, E., Hemminki, K.. Øvrebø, S., Haugen, A., Motykicwicz, G. and Chorazy, M. (1998) Modulation of DNA adducts in human mononuclear white blood cells and granulocytes by CYPIAI, CYP2D6 and CSTMI genetic polymorphisms. Mutat Res, 415, 97-108.

24. Wacker, H.H., Radzun, H.J. and Parwarcsch, M.R. (1986) Kinctics of kupffer cells as shown by parabiosis and combined autoradiographic/immunohistochemical analysis. Virchows Arch. B Cell Pathol Incl Mol Pathol, 51, 71-78.

25. Steptoc, R.J., Holt, P.G. and McMenamin, P.G. (1996) Origin and steady-state turnover of major histocompatibility complex class II positive dendritic cells and resident-lissue macrophages in the iris of the rat eye. $J$ Neuroimmunol, 68, 67-76.

26. Pavord, 1.D., Pizzichini, M.M.M., Pizzichini, E. and Hargreave, F.E. (1997) The use of induced sputum to investigate airway inflammation. Thorax, 52, 498-501.

27. Wilcosky, T.C. and Griffith, J.D. (1990) Application of biological markers. In: Hulka, B.S., Wilcosky, T.C. and Griffith, J.D. (eds.) Biological narkers in epidemiology. Oxford University Press, Oxford, pp.16-27.

28. Buckton, K.E. Brown, W.M.C. and Smith, P.G. (1967) Lymphocyte survival in men treated with $x-$ rays for ankylosing spondylitis. Nature, 214, 470-473.

29. Scherer, G. and Richter, E. (1997) Biomonitoring exposure to environmental tobacco smokc (ETS): a critical reappraisal. Hum Exp Toxicol, 16, 449-459.

30. Benowitz, N.L., Kuyt, F., Jacob, I.I.I.P., Jones, R.T. and Osman, A.L. (1983) Cotinine disposition and effects. Clin Pharmacol Ther, 34, 604-611.

31. Perez Stable, E.J., Benowitz, N.L. and Marin, G. (1995) Is serum cotinine a better measure of cigarette smoking than self-report? Prev Med, 24, 171-179.

32. Parazzini, F., Davoli, E., Rabaiotti, M., Restelli, S., Stramare, L., Dindelli, M., La Vecchia, C. and Fanelli, R. (1996) Validity of self-reported smoking habits in pregnancy: a saliva cotinine analysis. Acta Obstet Gynecol Scand, 75, 352-354.

33. Klebanoff, M.A., Levine, R.J., Clemens, J.D., Dersimonian, R., and Wilkins, D.G. (1998) Serum cotininc concentration and self-reported smoking during pregnancy. Am J Epidemiol, 148, 259-262. 
CHAPTER 4

IMMUNOHISTOCHEMISTRY OF DNA ADDUCTS IN SPUTUM 


\title{
Immunoperoxidase detection of 4-aminobiphenyl- and polycyclic aromatic hydrocarbon-DNA adducts in induced sputum of smokers and non-smokers
}

\author{
A. Besarati Nia', H.W.M. Van Straaten ${ }^{2}$, J.C.S. Kleinjans, F.J ${ }^{1}$. Van Schooten ${ }^{\bullet}$
}

'Department of Health Risk Analysis and Toxicology, Maastricht University, Maastricht, The Netherlands ${ }^{2}$ Department of Anatomy and Embryology, Maastricht University, Maastricht, The Netherlands

\begin{abstract}
Tobacco smoke constituents, 4-aminobiphenyl (4-ABP) and polycyclic aromatic hydrocarbons (PAH) possess carcinogenic properties as their reactive metabolites form DNA adducts. We studied the formation of 4-ABP- and PAH-DNA adducts in induced sputum, a non-invasively obtainable matrix from the lower respiratory tract, of smokers $(n=20)$ and nonsmokers $(n=24)$ by means of a semi-quantitative immunohistochemical peroxidase assay. Smokers had significantly higher levels of 4-ABP-DNA adducts as compared to non-smokers ( $0.08 \pm 0.02$ versus $0.04 \pm 0.01, P=0.001$, density of immunohistochemical staining), and the levels of adducts were related to current smoking indices (cigarettes/day, $r=0.3, P=0.04$ and $\operatorname{tar} /$ day, $r=0.4, P=0.02$ ). Likewise, smokers had elevated levels of PAH-DNA adducts as compared to non-smokers; however, the difference between the level of adducts in the two groups was not statistically significant $(0.13 \pm 0.02$ versus $0.08 \pm 0.02, \mathrm{P}=0.07)$. The levels of PAH-DNA adducts were only significantly related to the amount of tar consumed per day $(r=0.4, P=0.04)$ but not to the number of cigarettes smoked per day. Neither the levels of 4ABP-DNA adducts nor those of PAH-DNA adducts were related to smoking history index [pack years]. The levels of 4-ABP-DNA adducts were correlated with those of PAH-DNA adducts $(r=0.4, P=0.02)$. We conclude that immunohistochemistry of 4-ABP-DNA adducts in induced sputum is a specific approach to assess current exposure to tobacco smoke in the lower airway. However, in case of PAH-DNA adducts, such analysis is less specific because it does not explicitly reflect the magnitude of exposure.
\end{abstract}

Based on the manuscript published in:

"Mutat Res (2000) 468, 125-135" 


\section{Chapter Four}

\section{Immunohistochemistry of DNA adducts in sputum}

\section{INTRODUCTION}

Ample epidemiological data has unequivocally shown that tobacco smoking is a major risk factor for several human cancers (1). Of over 4000 chemicals present in tobacco smoke, aromatic amines and polycyclic aromatic hydrocarbons (PAH) are of particular interest in studying smoking-associated cancers. This is due to their proven carcinogenicity in experimental animals and/or humans (2-4). The carcinogenic properties of these chemicals are mainly ascribed to the capability of their reactive metabolites to bind covalently to cellular DNA and form DNA adducts (2,5). Since formation of DNA adducts is a triggering step in the carcinogenic process, dosimetry of DNA adducts might be used as a means to assess exposure to carcinogens as well as risk for cancer (6).

Amongst the techniques, which have been developed for quantification of carcinogenDNA adducts, the immunohistochemical assay has the merit of being specific and sensitive at the single cell level (7-12). Accordingly, when measurement of a particular carcinogen-DNA adducts at the morphological level is desired, the immunohistochemical assay would be a choice of preference.

Recently, we have shown the significantly higher level of smoking-related DNA adducts in induced sputum, a non-invasive derivative from the lower respiratory tract, of smokers as compared to non-smokers (13). Here, we used an immunohistochemical approach to specify the detected adducts in that study. Our objective was to characterize the class of DNA adducts, aromatic amine- and/or PAH-DNA adducts, in induced sputum, and find their relevance for exposure assessment in the airway. To achieve this, we assayed induced sputum cells of smokers and non-smokers by means of a semj-quantitative immunoperoxidase technique. This technique utilizes the monoclonal antibodies $4 \mathrm{Cl} 1$ and $5 \mathrm{D} 11$, which have proven specificities and sensitivities for recognizing 4-aminobiphenyl (4-ABP) - and PAH-DNA adducts, respectively (14-16).

\section{MATERIAL AND METHODS}

\section{Study Population}

Volunteers were recruited by advertising in the local newspapers. Upon enrollment, every individual filled out a self-administered questionnaire and signed an informed consent. Participants were selected based on the information elicited from their questionnaires with regard to age, gender, smoking behavior, alcohol consumption, medical history of disease, dietary/medicinal/occupational exposure to known carcinogens and familial history of cancer. Accordingly, two groups of healthy individuals consisting of 20 smokers [age, $39 \pm 11$; 
smoking status, $17 \pm 8$ cigarettes/day] and 24 lifelong non-smokers [age, $34 \pm 8$ ] with no occupational exposure to tobacco-related carcinogens were selected. Prior to sampling, all participants were interviewed in detail and briefed for sputum induction procedure. Table 1 summarizes the characteristics of the study population. The study was approved by the Medical Ethical Commission of Maastricht University.

\section{Sampling, Processing and Cytospin Preparation}

Sputum induction was performed according to the method of Pin (17) with some modifications. Briefly, after pretreatment with inhalatory salbutamol $[200 \mu \mathrm{g}]$, subjects inhaled ultrasonically nebulized $4.5 \%$ saline delivered from an Ultra-Neb 2000 (De Vilbiss, Somerset, PA) for a period of up to $21 \mathrm{~min}$. There were three 5 -min intervals at the end of each 7-min inhalation period. During the intervals, subjects rinsed their mouths, gargled their throats and then, coughed up the produced expectorate into a $50-\mathrm{ml}$ Greiner tube (Greiner Labortechnik, Frickenhausen, Germany) placed on ice. Additionally, they were instructed to cough up the available expectorate at any moment irrespective of the time of induction. Induction was terminated at the end of the $21 \mathrm{st} \mathrm{min}$ of inhalation or as soon as sufficient amount of sputum [at least $5 \mathrm{ml}$ ] was obtained.

Table 1. Characteristics of the study population and summary of DNA adducts analysis

\begin{tabular}{|c|c|c|}
\hline & Smokers & Non-smokers \\
\hline Number & 20 & 24 \\
\hline Gender (male/female) & $7 / 13$ & $6 / 18$ \\
\hline Age & $39 \pm 11$ & $34 \pm 8$ \\
\hline Cigarcıcs/day & $17 \pm 8$ & 0 \\
\hline Tar/day (mg) & $345 \pm 196$ & 0 \\
\hline Smoking ycars & $20 \pm 10$ & 0 \\
\hline Pack years & $18 \pm 14$ & 0 \\
\hline Immunohistochemistry of 4-ABP-DNA adducts" & $\begin{array}{c}0.08 \pm 0.02^{\mathrm{h}} \\
\text { Range: } 0.02-0.18\end{array}$ & $\begin{array}{c}0.04 \pm 0.01 \\
\text { Range: } 0.01-0.07\end{array}$ \\
\hline Immunohistochemistry of PAH-DNA adducts ${ }^{4}$ & $\begin{array}{c}0.13 \pm 0.02 \\
\text { Range: } 0.03-0.24\end{array}$ & $\begin{array}{c}0.08 \pm 0.02 \\
\text { Range: } 0.02-0.21\end{array}$ \\
\hline
\end{tabular}

${ }^{2}$ Expressed as density of immunohistochemical staining.

htatistically significant compared to non-smokers, $\mathrm{P}=0.001$. 
Induced sputum samples were processed by adding $0.1 \%$ Sputolysine (CalbiochemNovabiochem Corp., La Jolla, CA) [equal to 4 volumes of the samples], followed by incubation in a shaking water bath for $15 \mathrm{~min}$ at $37^{\circ} \mathrm{C}$. The samples were intermittently vortexed for $15 \mathrm{sec}$ and aspirated with a $5-\mathrm{ml}$ pipette. To quench the activity of the Sputolysine, 4 volumes of phosphate buffered saline (PBS), $\mathrm{pH} 7.4$ were added, and the incubation went by for another $5 \mathrm{~min}$. The resulting homogenates were centrifuged at $725 \times \mathrm{g}$ for $10 \mathrm{~min}$ at $4^{\circ} \mathrm{C}$ and resuspended in PBS. Subsequently, aliquots of $50 \times 10^{3}$ cells [diluted in PBS to a final volume of $300 \mu \mathrm{l}$ ] were made and then, cytocentrifuged (Shandon Cytospin ${ }^{\circledR}$, Cheshire, UK) at $1500 \mathrm{rpm}$ for 5 min onto Polysine ${ }^{\mathrm{TM}}$ microslides (E. Merck Nederland B.V., Amsterdam, the Netherlands). The slides were air dried for $1 \mathrm{~h}$ and finally, fixed in acetone at $20^{\circ} \mathrm{C}$ for $20 \mathrm{~min}$.

\section{Generation of 4-ABP Reactive Metabolites and Preparation of Control Slides for Immunohistochemistry of 4-ABP-DNA Adducts}

Microsomal-mediated metabolite production of 4-ABP was done using a $\$ 9$ mixture containing high levels of cytochrome P-4501A2 (18), which has been shown to efficiently activate 4-ABP (14). Briefly, $20 \mathrm{mM}$ 4-ABP (Aldrich-Chemie, Brussels, Belgium) dissolved in anhydrous dimethylsulfoxide (DMSO) [final concentration, $0.05 \%$ ] was added to a $40 \mathrm{mM}$ Tris- $\mathrm{HCl}, \mathrm{pH} 8.0$ buffered solution composed of microsomal protein $[1 \mathrm{mg} / \mathrm{ml}]$ obtained from the rats treated with phenobarbital and 3-methylcholanthrene, $2 \mathrm{mM} \mathrm{MgCl}_{2}$ and a regenerating system of glucose-6-phosphate [5mM], NADP ${ }^{+}[0.5 \mathrm{mM}]$ and glucose-6-phosphate dehydrogenase $[1.0 \mathrm{U} / \mathrm{ml}]$. Incubation was done in a shaking water bath for $1 \mathrm{~h}$ at $37^{\circ} \mathrm{C}$ in the dark. The solution was extracted three times with an equal volume of diethyl ether and subsequently, was residued by heating in a sand bath. To this residue of the microsomegenerated 4-ABP metabolites, an aliquot of induced sputum cells $\left[1 \times 10^{6}\right.$ cells $]$ of a nonsmoker was added, and incubation was carried out for $45 \mathrm{~min}$ at $37^{\circ} \mathrm{C}$ in the dark [to be used as positive control cells]. Parallelly, a second aliquot of the same induced sputum cells was incubated with another residue prepared exactly in the same manner as described above with the exception of the presence of 4-ABP in the initial step [to be used as negative control cells]. Cell suspensions were washed twice with PBS and ultimately, cytocentrifuged onto slides as described above. The prepared slides were used as controls in immunohistochemistry of 4ABP-DNA adducts in all experiments.

\section{Preparation of Control Slides for Immunohistochemistry of PAH-DNA Adducts}

Another two aliquots of the above-mentioned induced sputum cells were treated in vitro with 0 and $20 \mu \mathrm{M} 7 \beta, 8 \alpha$-dihydroxy-9 $\alpha, 10 \alpha$-epoxy-7,8,9,10-tetrahydrobenzo[a]pyrene, (( \pm )-antiBPDE) (Midwest Research Institute, Kansas City, MO) in anhydrous DMSO for 45 min at $37^{\circ} \mathrm{C}$ in the dark. Cell suspensions were washed twice with PBS and then, cytocentrifuged 
onto slides as described above. The prepared slides were used as controls in immunohistochemistry of PAH-DNA adducts in all experiments.

\section{Immunohistochemical Assay for 4-ABP-and PAH-DNA Adducts}

After rehydration, the slides were placed in a glass jar filled with prewarmed $\left[37^{\circ} \mathrm{C}\right] 100 \mathrm{mM}$ Citric Acid, pH 6.0, and irradiated in a microwave oven (Electrolux, Mod: EMM 2300-52/01) for 10 min at the highest power setting; our validation experiments have shown that this antigen retrieval procedure results in intensified nucleic staining [data not shown]. The slides remained in the jar out of the microwave for $30 \mathrm{~min}$ to be cooled down to room temperature, then, rinsed with tap water and re-rinsed with PBS for $2 \times 5 \mathrm{~min}$. Subsequently, they were incubated with $100 \mathrm{mg} / \mathrm{ml}$ RNase $A$ in Tris buffer [ $10 \mathrm{mM}$ Tris, $1 \mathrm{mM}$ EDTA, $400 \mathrm{mM} \mathrm{NaCl}$, $\mathrm{pH} 7.5$ ] for 1 hour at $37^{\circ} \mathrm{C}$, rinsed with PBS for $2 \times 5 \mathrm{~min}$ and treated with Proteinase $\mathrm{K}$ [50 $\mathrm{mg} / \mathrm{ml}$ in Tris buffer] for $10 \mathrm{~min}$ at $37^{\circ} \mathrm{C}$. Being rinsed with PBS, the slides were immersed in $4 \mathrm{~N} \mathrm{HCl}$ for $7 \mathrm{~min}$ to denature DNA, treated with $50 \mathrm{mM}$ Tris base for $5 \mathrm{~min}$ and then, rinsed with PBS for $2 \times 5$ min. To block the non-specific bindings of the primary antibodies, the slides were pre-incubated with $2 \%$ Bovine Albumin (Brunschwig, Amsterdam, the Netherlands) for $1 \mathrm{~h}$ at $37^{\circ} \mathrm{C}$. Subsequent incubations of the slides with the primary antibodies $4 \mathrm{C} 11$ and 5D 11 [kindly provided by Dr. R. Santella] [diluted 1:800 and 1:600, respectively, in $2 \%$ Bovine Albumin] were carried out overnight at $4^{\circ} \mathrm{C}$. Although the antibody 5D1l is specifically raised against ( \pm )-anti-BPDE-DNA adducts, due to its cross-reactivity with some structurally related PAH diol epoxide-DNA adducts $(15,16)$, the class of adducts recognized by it, is conventionally entitled PAH-DNA adducts. The following day, the slides were rinsed with PBS for $3 \times 5 \mathrm{~min}$ and incubated with biotinylated Anti-Mouse IgG $[\mathrm{H}+\mathrm{L}]$ (Brunschwig) [diluted 1:200 in $2 \%$ Bovine Albumin] for $30 \mathrm{~min}$ at $37^{\circ} \mathrm{C}$. After rinsing with PBS for $3 \times 5$, the slides were treated with $30 \% \mathrm{H}_{2} \mathrm{O}_{2}$ for $20 \mathrm{~min}$ at room temperature to quench the endogenous peroxidase activity and then, rinsed with PBS for $2 \times 5$ min. Immunoperoxidase staining of the slides was performed using a VECTASTANN ${ }^{\circledR} A B C$ system [Avidin $\mathrm{DH}+$ biotinylated horse-radish peroxidase $\mathrm{H}$ ] (Brunschwig) according to the instructions of the manufacturer. The stained slides were rinsed with PBS, dipped into $1 \%$ Triton X-100 (Merck, Darmstadt, Germany) for $30 \mathrm{sec}$ and re-rinsed with PBS. To visualize the immunoperoxidase staining, a 3, 3'-diaminobenzidine (DAB) substrate kit (Brunschwig) was used according to the instructions of the manufacturer. The slides were rinsed with tap water, dehydrated with graded ethanol and finally, cleaned with xylene.

\section{Quantification of the Immunohistochemistry of 4-ABP-and PAH-DNA Adducts}

Our validation experiments have shown that each cell type present in induced sputum requires specific conditions to be immunohistochemically stained. In other words, under the optimal conditions of the assay for one cell type e.g., particular dilution of the primary antibody, some 
other cell types may be over- or under-stained. Moreover, we have found that quantification of 200 cells per slide can prevent over- or under-estimation of staining, which occurs due to the heterogeneity of staining [data not shown]. As the validity of bronchoalveolar macrophages (BAM) for molecular dosimetry of inhalatory carcinogens has already been evidenced (1921 ), and as the major constituent of induced sputum is BAM [55\% and $77 \%$ in smokers and non-smokers, respectively, in our study], we optimized the assay for BAM and subsequently, utilized them for quantification [detailed information on cell differential of the induced sputum samples is available in Table 2 of ref. (13)].

Quantification was done applying an Image Processing and Analysis System (Quantimet 500, Leica, Cambridge, UK) through measuring the relative intensities of staining in nuclear, cytoplasmic and extracellular [back ground] areas in 200 morphologically well-defined BAM [Fig. 1] per slide. To rule out the inter-observer bias, all image analyses were performed by one of the authors (A.BN). Stain intensities of nucleus and cytoplasm were divided by that of extracellular area in order to obtain nucleic and cytoplasmic transmissions, respectively. Negative logarithm of transmission was taken to calculate absorbance which in turn, is linearly related to the stain density. The stain density of cytoplasm was subtracted from that of nucleus to correct for background density of staining. In principle, as stain density in nucleus is proportional to the level of DNA adducts, the corrected nucleic stain density in every individual cell represented its DNA adducts level [range, $0.00-2.40$ ]. For example, if the relative intensities of staining in nuclear, cytoplasmic and extracellular areas of a BAM were 150,240 , and 250 , respectively, its nucleic and cytoplasmic transmissions were $\{150 / 250=$ $0.60\}$ and $\{240 / 250=0.96\}$, respectively, its nucleic and cytoplasmic stain densities were $\{-$ $\log [0.60]=0.22\}$ and $\{-\log [0.96]=0.02\}$, respectively, and its corrected nucleic stain density was $\{0.22-0.02=0.20\}$. Final immunohistochemistry value for each slide representing its 4-ABP- or PAH-DNA adducts level was the mean of nucleic stain densities in 200 BAM measured in the slide.

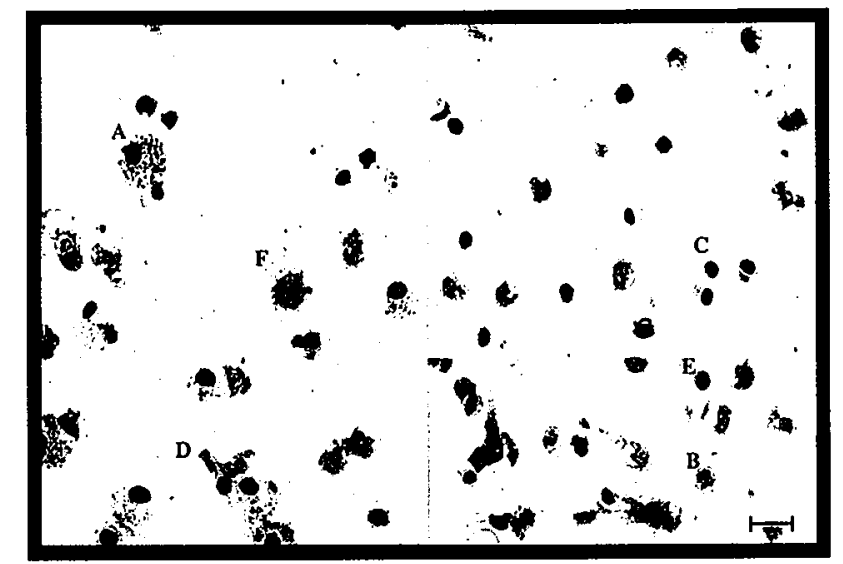

Fig. 1. Representative cell composition of induced sputum sample from a smoker [for visualization, five sections of the slide are assembled together by Image Processing and Analysis System (Quantimet 500, Leica, Cambridge, UK)], A, BAM; B, Neutrophil; C, Bronchoepithelial cell; D, Ciliated cell; E, Lymphocyte; F, Squamous cell. May Grünwald-Giemsa staining. bar, $50 \mu \mathrm{m} . \times 800$ magnification. 
Assessment of the intra-assay variation was done by staining duplicate slides from several smokers and non-smokers. The intra-assay coefficient of variation was $8.1 \pm 3.3 \%(n=18)$. To evaluate the inter-assay variation some of the above-mentioned slides were stained in three independent experiments. The inter-assay coefficient of variation was $11.4 \pm 4.6 \%(n=15)$. The sensitivity and specificity of staining in all experiments were checked by examining the control slides [made of induced sputum cells treated in vitro with and without reactive metabolites of 4-ABP and ( \pm )-anti-BPDE] [Fig. 2]. The control slides were also used for standardization of the results obtained from different sets of experiments. Additional examination of the specificity included re-staining of the most heavily stained slides either after pretreatment with DNase I (Amersham Pharmacia Biotech, Piscataway, NJ) [0.5 U/slide] for $45 \mathrm{~min}$ at $37^{\circ} \mathrm{C}$, or after omission of the primary antibodies. In neither case, the nucleic stain density could measurably exceed the cytoplasmic density of staining throughout the slides [Fig. 3].

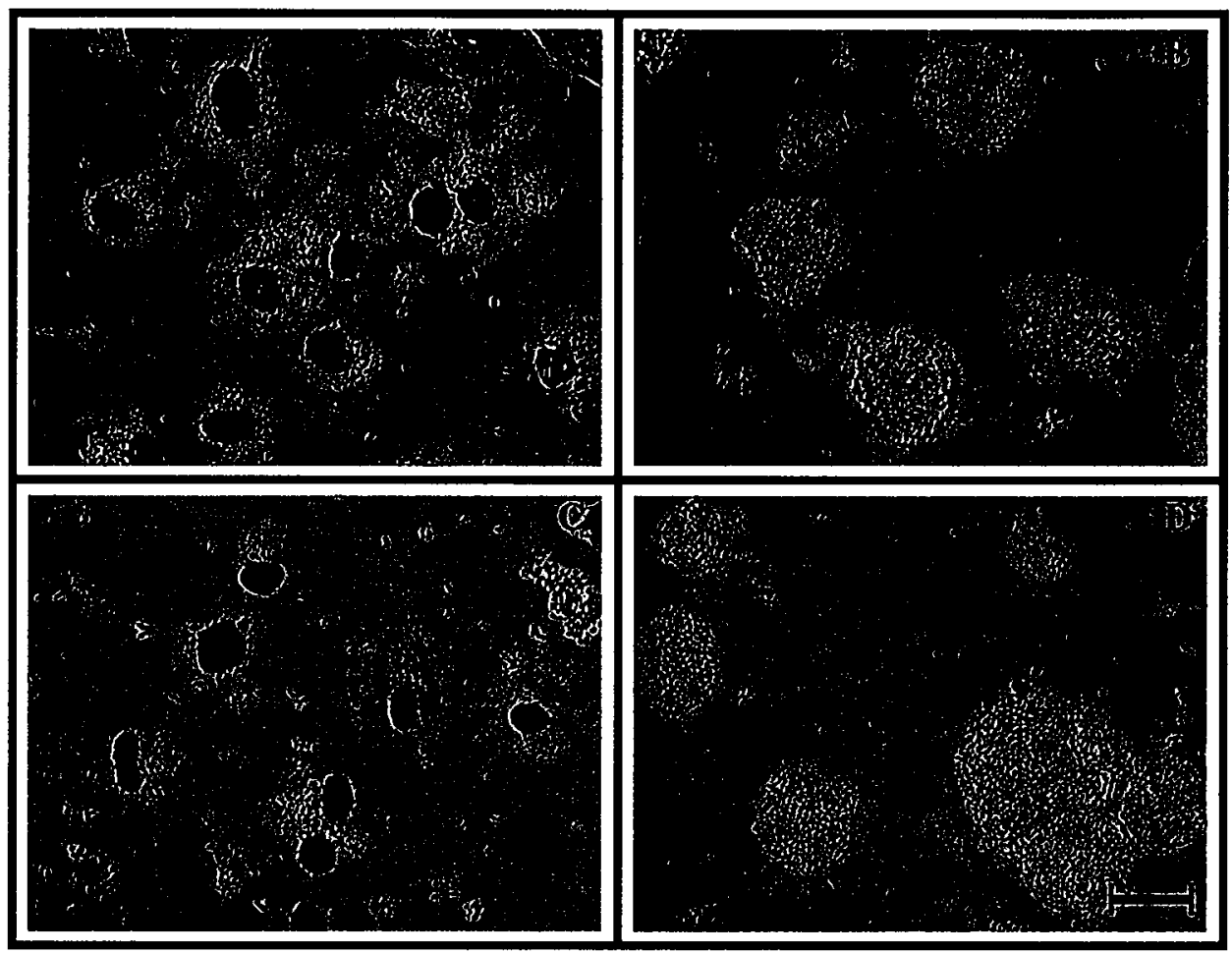

Fig. 2. Immunoperoxidase staining of 4-ABP- and PAH-DNA adducts in induced sputum of a non-smoker treated in vitro with and without reactive metabolites of 4-ABP (A, B, respectively) and ( \pm )-anti-BPDE, (C, D, respectively). bar, $50 \mu \mathrm{m} . \times 800$ magnification. 


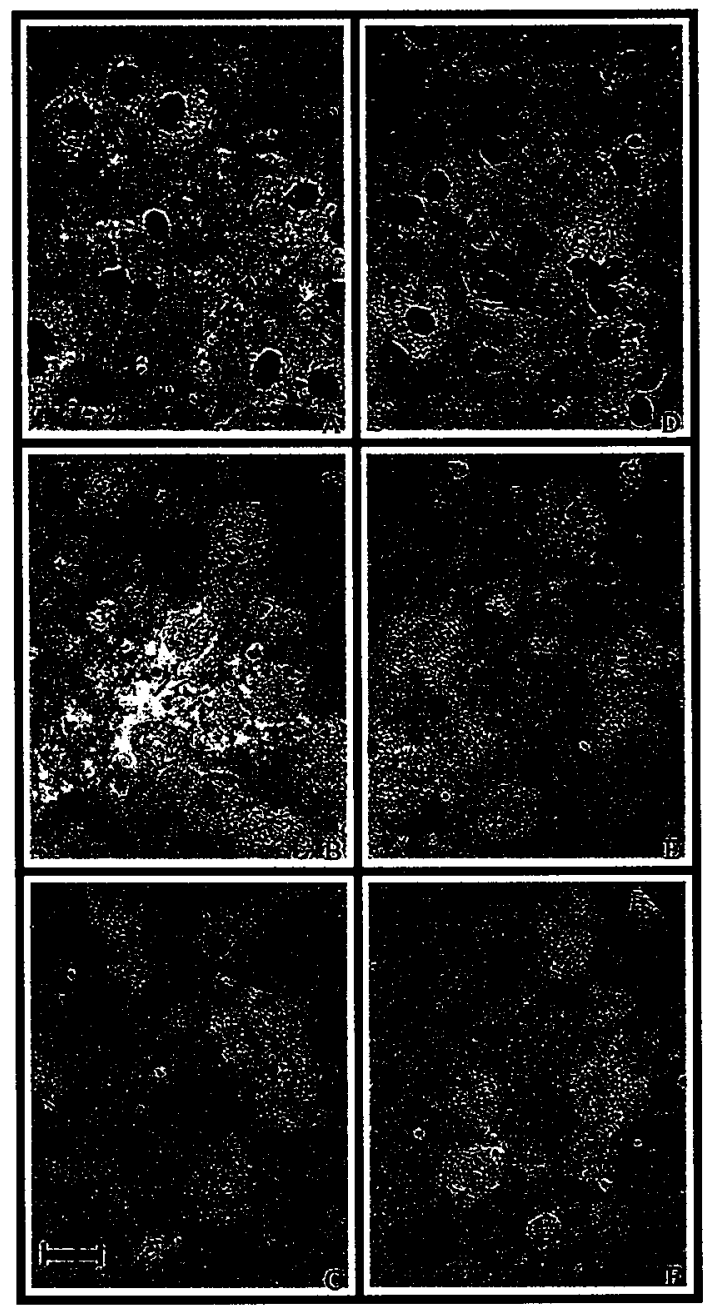

Fig. 3. Immunoperoxidase staining of 4-ABP- and PAH-DNA adducts in induced sputum of a smoker without any pre-treatment (A, D, respectively) and after pre-treatment with DNase $I$ (B, E, respectively) and omission of the primary antibodies $4 \mathrm{C} 11,5 \mathrm{D} 11$ (C, F, respectively). bar, $50 \mu \mathrm{m} . \times 800$ magnification.

\section{Statistical Analysis}

Results were expressed as mean \pm SEM. The Mann-Whitney $U$-test was used to compare the levels of adducts between smokers and non-smokers. The Spearman rank correlation coefficient was calculated to assess the relationships between various variables. Statistical significance was considered at $\mathrm{P}<0.05$. 


\section{RESULTS}

\section{Immunohistochemistry of 4-ABP-DNA Adducts}

Immunohistochemistry of 4-ABP-DNA adducts in BAM of the induced sputum samples revealed significantly higher levels of adducts in smokers compared to non-smokers $(0.08 \pm$ 0.02 versus $0.04 \pm 0.01, \mathrm{P}=0.02$ ) [Tab. 1]. Distribution of the levels of adducts in smokers and non-smokers are presented in Figure 4. Adduct levels ranged from 0.02 to 0.18 and from 0.01 to 0.07 in smokers and non-smokers, respectively. Figure $5[\mathrm{~A}, \mathrm{~B}]$ illustrates the representatives of immunoperoxidase staining in induced sputum of a smoker and a nonsmoker.

There were significant relationships between the levels of adducts and current smoking indices expressed as number of cigarettes smoked per day $(r=0.3, P=0.04)$ and amount of tar consumed per day $(r=0.4, P=0.02)$. Excluding the non-smokers from these analyses, however, such relationships could not be established any longer. There was no relationship between the levels of adducts and smoking history index expressed as pack years [number of cigarettes smoked per day $/ 20 \times$ smoking years]. Nor was there any association between the levels of adducts and gender or age. In non-smokers, the levels of adducts were not influenced by passive smoking [passive smoking index was the number of hours per day spent in a smoking area]. Based on the information derived from the questionnaires, there was no difference between smokers and non-smokers with regard to other lifestyle confounding factors e.g., diet, therefore, we did not analyze our data in relation to such variables.

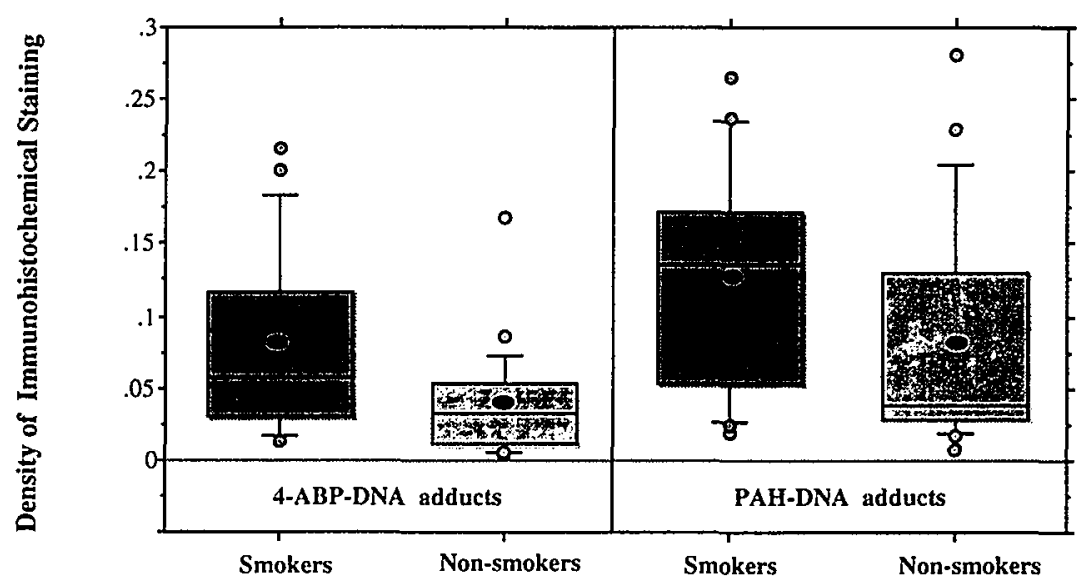

Fig.4. Distribution of the levels of 4-ABP- and PAH-DNA adducts in induced sputum of smokers and nonsmokers. The lower and upper edges of the boxes, the $25^{\text {th }}$ and the $75^{\text {th }}$ percentiles, respectively. 0 and - within the boxes, the means and the medians, respectively. Lower and upper bars, the $10^{\text {th }}$ and the $90^{\text {th }}$ percentiles, respectively. 0 , Individual values $<10^{\text {th }}$ or $>90^{\text {th }}$ percentiles. 


\section{Immunohistochemistry of PAH-DNA Adducts}

Immunohistochemistry of PAH-DNA adducts in BAM of the induced sputum samples showed non-significant elevation of the levels of adducts in smokers as compared to nonsmokers $(0.13 \pm 0.02$ versus $0.08 \pm 0.02, \mathrm{P}=0.07)$ [Tab. 1]. Distribution of the levels of adducts in smokers and non-smokers are shown in Figure 3. Adduct levels varied in the ranges of $0.03-0.24$ and $0.02-0.21$ in smokers and non-smokers, respectively. Figure $5[\mathrm{C}$, D] depicts the representatives of immunoperoxidase staining in induced sputum of a smoker and a non-smoker.

There was a significant relationship between the levels of adducts and the amount of tar consumed per day $(r=0.4, P=0.04)$. However, the relationship between the levels of adducts and the number of cigarettes smoked per day did not reach a statistically significant level $(\mathrm{r}=$ $0.3, \mathrm{P}=0.06$ ). Excluding the non-smokers from these analyses, no relationships could be observed between the levels of adducts and either of the current smoking indices. Adduct levels were not related to the smoking history index, either. Nor were the levels of adducts associated with age or gender. Adduct levels in non-smokers were not affected by passive smoking. Overall, there was a significant correlation between the levels of PAH-DNA adducts and those of 4-ABP-DNA adducts ( $r=0.4, \mathrm{P}=0.02)$.

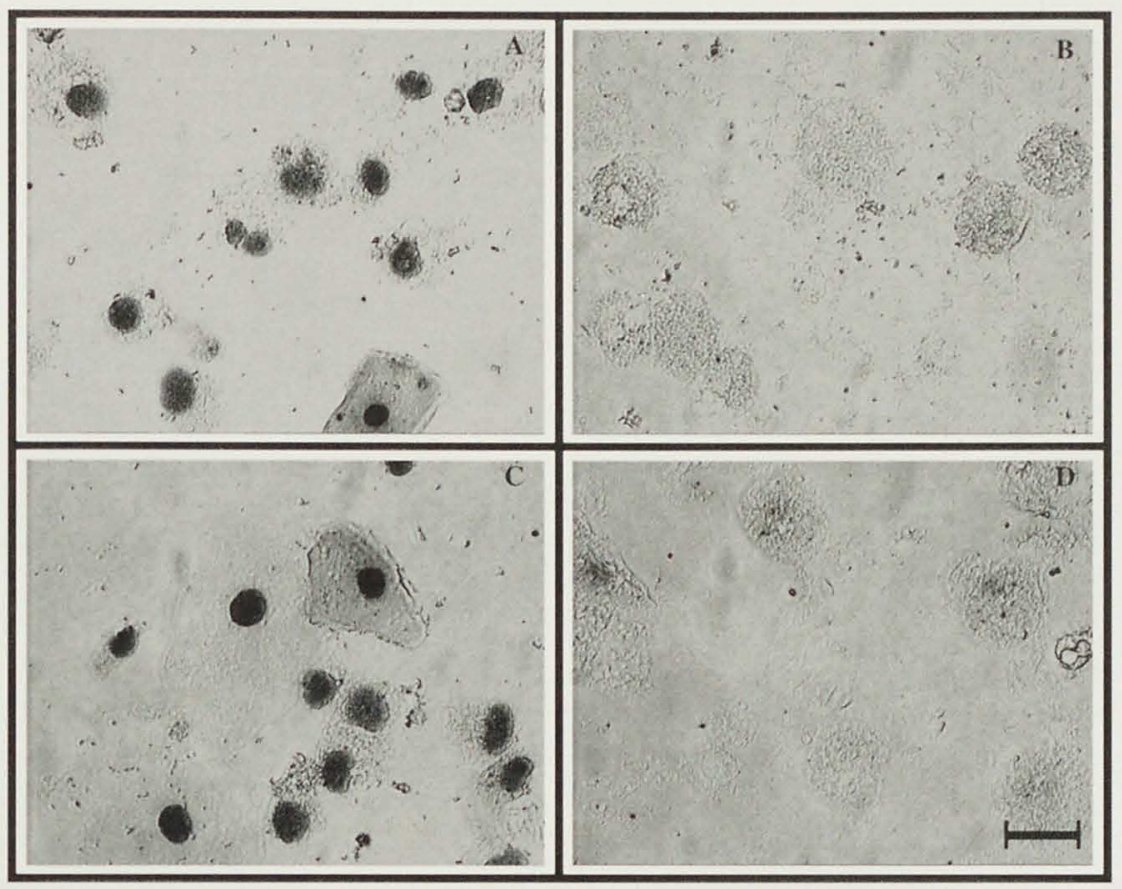

Fig. 5. Immunoperoxidase staining of 4-ABP- and PAH-DNA adducts in induced sputum of a smoker (A, C, respectively) and a non-smoker ( $\mathrm{B}, \mathrm{D}$, respectively). bar, $50 \mu \mathrm{m} . \times 800$ magnification. 


\section{DISCUSSION}

The evidence that tobacco smoking is a main risk factor for several human cancers is overwhelming (1). Aromatic amines and PAH are two major classes of carcinogens present in tobacco smoke, which have been shown to be involved in human bladder and respiratory tract cancers, respectively (2-4). Recently, we have verified the relevance of smoking-related DNA adduct analysis in induced sputum, a non-invasive derivative from the lower respiratory tract, for exposure assessment in the airway (13). We have also shown the comparability of adduct analysis in induced sputum with that in bronchoalveolar lavage (BAL) cells, an already validated but invasively obtainable matrix $(13,19-21)$. In the present study, we utilized an immunohistochemical approach to quantify 4-ABP- and PAH-DNA adducts as the biologically effective dose markers of exposure to aromatic amines and $\mathrm{PAH}$, respectively, in induced sputum of smokers and non-smokers.

We found higher levels of 4-ABP-DNA adducts in induced sputum of smokers as compared to non-smokers. This is in good agreement with the findings of other studies performed in the target tissues e.g., bladder and exfoliated urothelial cells $(7,22)$ as well as other tissues [larynx and exfoliated oral cells] $(7,11,23)$. Interestingly, there was a notable resemblance between our 4-ABP-DNA adducts data in induced sputum and those in larynx (23). First, adduct levels in induced sputum and laryngeal cells of smokers were 2.0 and 2.2 times, respectively, higher than those in non-smokers. Secondly, there were 9- and 7-fold ranges in the level of adducts in induced sputum of smokers and non-smokers, respectively. In the larynx, the respective ranges were 6- and 5-fold for smokers and non-smokers. Given the comparable exposure pattern and the similarity of results, we may consider induced sputum as a representative for tissues from the lower airway.

Furthermore, we observed elevated levels of PAH-DNA adducts in induced sputum of smokers; however, the difference between the level of adducts in smokers and non-smokers was not statistically significant. This latter may support the findings of Shamsuddin et al. that denied an unequivocal immunoreactivity of smokers' lung tissues for ( \pm )-anti-BPDE-DNA adducts (24). The former, however, has been demonstrated in a significant fashion in exfoliated oral and urothelial cells and blood lymphocytes $(7,9,10,12)$. Obviously, induced sputum and the above-mentioned tissues are exposed to different sources of carcinogens via various routes. As an analogy, induced sputum cells are mainly exposed to inhalatory carcinogens whereas oral cells are subject to both ingested and inhaled carcinogens. Thus, it is possible that a non-significant difference between the level of PAH-DNA adducts in induced sputum of smokers and non-smokers may be augmented in the oral mucosa and manifest significantly.

One might argue the above-mentioned dissimilarity between PAH-DNA adduct analysis in induced sputum and exfoliated oral and urothelial cells, and the similarity between 4-ABPDNA adduct analysis in induced sputum and the same tissues as described earlier $(7,10,12,22)$. It should be taken into account that the passive exposure to $\mathrm{PAH}$ as ubiquitous environmental pollutants (25), can be much higher than that to aromatic amines $(26,27)$. Therefore, it is likely that PAH-DNA adducts in any given tissue are more affected by such confounding exposure compared to 4-ABP-DNA adducts. With the same token, we may consider that the prevailing environmental exposure to $\mathrm{PAH}$ intensifies the background levels 
of PAH-DNA adducts in non-smokers thereby, narrowing the gap between the levels of adducts in smokers and non-smokers. Convincingly, the herein wider range of PAH-DNA adducts as compared to 4-ABP-DNA adducts in the non-smokers [10.5 versus 7.0$]$ supports this idea. At the same time, it emphasizes the interindividual variation in activation/detoxification and DNA repair activities (28-31). Unfortunately, our non-smoking group was proportionally small in size, therefore, we could not elaborate upon the impact of environmental exposure to PAH or aromatic amines. Nonetheless, the high levels of adducts specially PAH-DNA adducts in some of the non-smokers could, at least, verify the existence of such exposure. We acknowledge that the observed discrepancy between immunohistochemistry of 4-ABP-DNA adducts and that of PAH-DNA adducts in smokers versus non-smokers could have been to some extent due to the unidentical specificities of $4 \mathrm{C} 11$ and 5D11 antibodies. In fact, it has been reported that 5D11 cross-reacts slightly with some structurally related PAH diol epoxide-DNA adducts, whereas $4 \mathrm{C} 11$ has no crossreactivity with several other $\mathrm{C} 8$ aromatic amine adducts but with non-modified calf thymus DNA (14-16). Of course, we ruled out this possibility as much as we could by optimizing the sensitivity and specificity of the immunohistochemistry for both antibodies in a comparable way. This was demonstrated by the readily distinguishable nucleic staining in all positive controls and almost negligible nucleic staining in all negative controls for both 4-ABP- and PAH-DNA adducts.

Lastly, we observed dose-response relationships between the levels of 4-ABP-DNA adducts and both the number of cigarettes smoked per day and the amount of tar consumed per day. In case of PAH-DNA adducts, such dose-dependency was only found when the latter exposure index was applied. This could be explained by the fact that PAH are abundantly present in the tar content of tobacco smoke (4). Hence, in studying tobacco-associated PAHDNA adducts, tar consumption per day can be a more relevant exposure indicator. It should be noted that like most other studies (32), these dose-response relationships were partially dependant upon the contribution of the non-smokers. Nonetheless, given the limited number of smokers and the wide inter-individual variations in their adduct levels, this would be statistically justifiable (33). The lack of relationships between the levels of 4-ABP- or PAHDNA adducts and the cumulative dose of exposure [pack years] was not unexpected. Indeed, BAM [the representative of sputum cells in this study] are short lived cells with a life span of 12 - 15 days $(34,35)$, thereby mirroring only the acute exposure to carcinogens.

In summary, we conclude that exposure to tobacco smoke results in increased levels of 4-ABP- as well as PAH-DNA adducts in induced sputum. However, the magnitude of increase for 4-ABP-DNA adducts is more explicit than that for PAH-DNA adducts. Thus, dosimetry of 4-ABP-DNA adducts can be considered as a more specific approach to assess exposure to tobacco smoke in the lower respiratory tract. 


\section{REFERENCE}

1. World Health Organization (1997) Health effects. In World Health Organization (ed.), Tobacco or Health: a global status report. Vol. 1. World Health Organization, Geneva, pp. 43-48.

2. Patrianakos, C. and Hoffman D. (1979) Chemical studies on tobacco smoke LXIV. On the analysis of aromatic amines in cigarette smoke. $J$ Anal Chem, 3, 150-154.

3. International Agency for Research on Cancer (1986) Tobacco smoking. In Monographs on the evaluation of the carcinogenic risk of chemicals to humans. Vol. 38, International Agency for Research on Cancer,Lyon (France), pp. 37-375.

4. Hoffmann, D. and Hoffmann I. (1997) The changing cigarette, 1950-1995. J Toxicol Environ Health, 50, 307-364.

5. Miller, E.C. and Miller J.A. (1981) Searches for ultimate chemical carcinogens and their reactions with ccllular macromolecules. Cancer, 47, 2327-2345.

6. Hemminki, K. (1993) DNA adducts, mutations and cancer. Carcinogenesis, 14, 2007-2012.

7. Hsu, T.M., Zhang Y.J. and Santclla R.M. (1997) Immunoperoxidase quantitation of 4-aminobiphenyland polycyclic aromatic hydrocarbon-DNA adducts in exfoliated oral and urothclial cells of smokers and nonsmokers. Cancer Epidemiol Biomarkers Prev, 6, 193-199.

8. Poirier, M.C. (1993) Antisera specific for carcinogen-DNA adducts and carcinogen-modificd DNA: applications for detection of xenobiotics in biological samples. Murat Res, 288, 31-38.

9. Motykiewicz, G., Malusecka E., Grzybowska E., Chorazy M., Zhang Y.J., Perera F.P. and Santella R.M. (1995) Immunohistochemical quantitation of polycyclic aromatic hydrocarbon-DNA adducts in human lymphocytes. Cancer Res, 55, 1417-1422.

10. Zhang, Y.J., Hsu T.M. and Santella R.M. (1995) Immunoperoxidase detcction of polycyclic aromatic hydrocarbon-DNA adducts in oral mucosa cells of smokers and nonsmokers. Cancer Epidemiol Bionarkers Prev, 4, 133-138.

11. Romano, G., Mancini R., Fedele P., Curigliano G., Flamini G., Giovagnoli M.R., Malara N., Boninsegna A., Vecchione A., Santella R.M. and Cittadini A. (1997) Immunohistochemical analysis of 4-aminobiphenyl-DNA adducts in oral mucosal cells of smokers and nonsmokers. Anticancer Res, 17, 2827-2830.

12. Romano, G., Sgambato A., Boninsegna A., Flamini G., Curigliano G., Yang Q., La Gioia V., Signorelli C., Ferro A., Capelli G., Santella R.M. and Cittadini A. (1999) Evaluation of polycyclic aromatic hydrocarbon-DNA adducts in exfoliated oral cells by an immunohistochemical assay. Cancer Epidemiol Biomarkers Prev, 8, 91-96.

13. Nia, A.B., Maas L.M., Van Breda S.G., Curfs D.M., Kleinjans J.C., Wouters E.F. and Van Schooten F.J. (2000) Applicability of induced sputum for molecular dosimetry of cxposure to inhalatory carcinogens: "2.postlabeling of lipophilic DNA adducts in smokers and nonsmokers. Cancer Epidemiol Biomarkers Prev, 9, 367-372.

14. Al-Atrash, J., Zhang Y.J., Lin D., Kadlubar F.F. and Santella R.M. (1995) Quantitative immunohistochemical analysis of 4-aminobiphenyl-DNA in cultured cells and mice: comparison to gas chromatography/mass spectroscopy analysis. Chem Res Toxicol, 8, 747-752.

15. Santella, R.M., Lin C.D., Cleveland W.L. and Weinstein I.B. (1984) Monoclonal antibodies to DNA modified by a benzo[a]pyrene diol epoxide. Carcinogenesis, 5, 373-377.

16. Santella, R.M., Dharmaraja N., Gasparro F.P. and Edeison R.L. (1985) Monoclonal antibodies to DNA modified by 8-methoxypsoralen and ultraviolet A light. Nucleic Acids Res, 13, 2533-2544. 
17. Pin, I., Gibson P.G., Kolendowicz R., Girgis-Gabardo A., Denburg J.A., Hargreave F.E. and Dolovich J. (1992) Use of induced sputum cell counts to investigate airway inflammation in asthma. Thorax, 47. 25-29.

18. Oakley, G.G., Robertson L.W. and Gupta R.C. (1996) Analysis of polychlorinated biphenyl-DNA adducts by "P-postlabeling. Carcinogenesis. 17, 109-114.

19. Izzoui, A., Rossi G.A.. Bagnasco M. and De Flora S. (1991) Benzo[a]pyrene diolepoxidc-DNA adducts in alveolar macrophages of smokers. Carcinogenesis, 12, 1281-1285.

20. De Flora, S., Izzotti A., D'Agostini F., Rossi G.A. and Balansky R.M. (1993) Pulmonary alveolar macrophages in molecular cpidcmiology and chemoprevention of cancer. Environ Health Perspect, 99. 249-252.

21. Van Schooten. F.J. Godschalk R.W., Breedijk A., Maas L.M., Kriek E., Sakai H., Wigbout G., Baas P., Van't Veer L. and Van Zandwijk N. (1997) "P-postlabelling of aromatic DNA adducts in white blood cells and alveolar macrophages of smokers: saturation at high exposures. Mutar Res, 378, 65-75.

22. Curigliano. G., Zhang Y.J., Wang L.Y., Flamini G., Alcini A., Ratto C., Giustacchini M., Alcini E., Cittadini A. and Santella R.M. (1996) Immunohistochemical quantitation of 4-aminobiphenyl-DNA adducts and p53 nuclear overexpression in $T 1$ bladder cancer of smokers and nonsmokers. Carcinogenesis, 17, $911-916$.

23. Flamini. G., Romano G., Curigliano G., Chiominto A., Capelli G., Boninsegna A., Signorelli C., Ventura L., Santella R.M., Sgambato A. and Cilladini A. (1998) 4-Aminobiphenyl-DNA adducts in laryngeal tissue and smoking habits: an immunohistochemical study. Carcinogenesis, 19, 353-357.

24. Shamsuddin. A.K. and Gan R. (1988) Immunocylochemical localization of benzo[alpyrene-DNA adducts in human tissue. Hum Pathol. 19, 309-315.

25. International Agency for Research on Cancer. (1983) Monographs on the evaluation of the carcinogenic risk of chemicals to humans, Part 1. Vol. 32. International Agency for Research on Cancer, Lyon (France).

26. Perera, F.P., Santella R.M., Brenner D., Poirier M.C., Munshi A.A., Fischman H.K. and Van Ryzin J. (1987) DNA adducts, protein adducts, and sister chromatid exchange in cigarette smokers and nonsmokers. J Natl Cancer Inst, 79, 449-456.

27. Phillips, D.H. and Hewer A. (1993) DNA adducts in human urinary bladder and other tissues. Environ Health Perspect, 99, 45-49.

28. Ocsch, F., Aulmann W., Platt K.L. and Doerjer G. (1987) Individual differences in DNA repair capacities in man. Arch Toxicol Stupl, 10, 172-179.

29. Harris, C.C. (199I) Chemical and physical carcinogenesis: advances and perspeclives for the 1990s. Cancer Res, 51, 5023s-5044s.

30. Hemminki, K. (1991) Interindividual variation in the level of DNA and protein adducts in humans. In Grandjean, P. (ed.), Ecogenetics. Chapman \& Hall, London, pp. 217-234.

31. Celotti, L., Ferraro P. and Biasin M.R. (1992) Detection by fluorescence analysis of DNA unwinding and unscheduled DNA synthesis, of DNA damage and repair induced in virro by dircct-acting mutagens on human lymphocytes. Murat Res, 281, 17-23.

32. Kriek, E., Rojas M., Alcxandrov K. and Bartsch H. (1998) Polycyclic aromatic hydrocarbon-DNA adducts in humans: relevance as biomarkers for exposure and cancer risk. Mutat Res, 400, $215-231$.

33. Altman, D. (1991) Clinical Trails. In Altman, D. (ed.), Practical Statistics for Medical Research. Chapman and Hall, London. pp. 440-476. 
34. Wacker, H.H., Radzun H.J. and Parwaresch M.R. (1986) Kinctics of Kupffer cells as shown by parabiosis and combined autoradiographic/inmunohistochemical analysis. Virchows Arch B Cell Pathol Incl Mol Pathol, 51, 7I-78.

35. Steptoc, R.J., Holt P.G. and McMenamin P.G. (1996) Origin and steady-state turnover of major histocompatibility complex class II-positive dendritic cells and resident-tissue macrophages in the iris of the rat eye. J Neuroimmumol, 68, 67-76. 


\section{CHAPTER 5}

EXPOSURE ASSESSMENT FOR ENYIRONMENTAL TOBACCO SMOKE 


\title{
Assessment of exposure to environmental tobacco smoke in pubs
}

\author{
A. Besarati Nia', L.M. Maas', E.M.C. Brouwer', E.J.C. Moonen', T.M.C.M. De Kok', G.J. \\ Wesseling', J.C.S. Kleinjans', F.J. Van Schooten ${ }^{1 *}$
}

'Department of Health Risk Analysis and Toxicology, Maastricht University, Maastricht, The Netherlands 2Department of Pulmonology, Academic Hospital Maastricht, Maastricht, The Netherlands

\begin{abstract}
Although the involvement of environmental tobacco smoke (ETS) in human lung cancer is no longer a matter of dispute, the magnitude of its impact still is. This is mainly due to the inefficiency of methodology to assess exposure to ETS especially in public places. We measured smoke-related DNA adducts in induced sputum and peripheral blood lymphocytes (PBL) of non-smokers $(n=15)$ who voluntarily exposed themselves to ETS in pubs for $3 \mathrm{~h}$ at pre- and post-exposure times $\left(\mathrm{T}_{0}\right.$ and $\mathrm{T}_{1}$, respectively) by the ${ }^{32} \mathrm{P}$-postlabeling assay. Simultaneously, we quantified a spectrum of polycyclic aromatic hydrocarbons (PAH) in the ambient air of the pubs using personal air monitors. Mean concentrations of individual and total PAH $\left[\mathrm{ng} / \mathrm{m}^{3}\right]$ in the ambient air of the pubs were as follows, benzo[a]anthracene, 12.3; chrysene, 18.1; benzo[b]fluoranthene, 4.5 ; benzo[k]fluoranthene, 1.0; benzo[a]pyrene, 6.3 ; total PAH, 42.3. Overall, the DNA adduct profile in induced sputum consisted of three distinct spots [spot $1,2,3]$ and a faint diagonal radioactive zone (DRZ). Spot 1 was present only at $T_{1}$ in three samples, and co-migrated with the standard ( \pm -anti-benzo[a]pyrene diol epoxideDNA adduct spot. The other two spots and the DRZ were observed both at $T_{0}$ and $T_{1}$ in different samples. The spot 2 was significantly enhanced at $T_{1}$ as compared to $T_{0}(P=0.04)$. The spot 3 and the DRZ did not change significantly at $T_{1}$ as compared to $T_{0}$. The overall spots and DRZ corresponding to total level of adducts was only marginally enhanced at $T_{1}$ as compared to $T_{0}\left(1.57 \pm 0.69\right.$ versus $1.40 \pm 0.44 / 10^{8}$ nucleotides, $\left.P=0.7\right)$. No detectable level of adducts was observed in PBL of most individuals either at $T_{0}$ or at $T_{1}$; only three samples had fairly quantifiable DNA adducts which did not correlate with the respective induced sputum DNA adducts. Overall, there was no relationship between DNA adduct dosimetry data and personal air monitoring data. We conclude that dosimetry of DNA adducts in induced sputum needs further validation before it can be used as an integral approach to assess exposure to ETS.
\end{abstract}

Based on the manuscript submitted for publication in:

"Cancer Causes Controls" 


\section{Chapter Five}

\section{Exposure assessment for environmental tobacco smoke}

\section{INTRODUCTION}

Compelling evidence shows the link between exposure to environmental tobacco smoke (ETS) and lung cancer (1-4). Yet, the magnitude of risk for ETS-related lung cancer is not well established [reviewed in ref. (5)]. The uncertainty arises from the methodological inefficiency in assessing exposure to ETS. By and large, ETS exposure profile is highly variable because it emanates from multiple origins, in varying compositions and concentrations and for different durations (6). Ideally, exposure assessment for ETS would involve specific and sensitive measurements of ETS in the environment as well as in the internal milieu of the body (6-8). The former can be achieved by monitoring of the ambient air for various ETS constituents, whereas the latter can be done by dosimetry of these constituents in the body fluids or by quantifying them after their interaction with subcellular targets e.g., DNA, RNA and proteins $(9,10)$.

Polycyclic aromatic hydrocarbons (PAH) are a major class of carcinogens present in ETS (11) and have been implicated in the etiology of several human cancers including cancer of the lower respiratory tract (12). The carcinogenicity of PAH is mostly ascribed to their specific chemical structures, which enable them to bind covalently to DNA and form DNA adducts (13). Formation of DNA adducts is an event of potential significance in carcinogenesis because it may give rise to chromosomal aberrations, DNA strand breaks, oncogene activation and tumor suppressor gene inactivation (14-16). Hence, DNA adduct formation can represent a prior exposure to carcinogens, as well as a risk for cancer (15). Theoretically, dosimetry of DNA adducts should be performed within the organs where tumor arises [target organs]. Practically, however, most target organs for $\mathrm{PAH}$-associated cancers are only invasively accessible $(17,18)$. Also, the commonly used non-target organs show inconsistent surrogacy for the target ones $(19,20)$. This latter might relate to the incomparability of exposure patterns in surrogate versus target organs. In addition, different cell compositions with varying biotransformational and DNA repair capacity in target and surrogate organs may also be responsible for such inconsistency $(21,22)$. Recently, we have shown the applicability of induced sputum, a non-invasive derivative from the lower airway, for dosimetry of smoke-related DNA adducts $(23,24)$. Here, we analyze induced sputum and peripheral blood lymphocytes (PBL) for the presence of smoke-related DNA adducts consequent to exposure to ETS. Thus, in a group of non-smokers exposed voluntarily to ETS in the pubs, we quantify aromatic/hydrophobic-DNA adducts in induced sputum and PBL pre- and post-exposure by the nuclease $\mathrm{Pl}$ (NPI) enhanced ${ }^{32} \mathrm{P}$-postlabeling assay. To complement our DNA adduct dosimetry data, we also measure the concentrations of a spectrum of PAH in the ambient air of the pubs using personal air monitors. 


\section{MATERIAL AND METHODS}

\section{Study Population}

Volunteers were undergraduate students of Faculty of Health Sciences, Maastricht University, Maastricht, the Netherlands. Upon enrollment, each individual filled out a questionnaire on his/her agc, gender, active and passive smoking status, alcohol consumption, dietary intake, medical history of disease and familial history of cancer. Subsequently, fifteen healthy nonsmokers who had no extensive history of exposure to ETS, were selected and signed an informed consent. As part of our study protocol, they all abstained from visiting a pub, nightclub or any smoky site at least two weeks prior to the experiment. The study population consisted of eleven females and four males with an average age of $22 \pm 1.5$ years [Mean \pm $\mathrm{SD}$. For logistic reasons, they were sub-divided in three groups of 4 individuals and one group of 3 individuals. The study was approved by the Medical Ethical Commission of Maastricht University.

\section{Study Protocol}

Before pre-sampling, all participants were interviewed in detail and briefed on the study protocol. After collection of peripheral blood and sputum, subjects were equipped with a personal air monitor and then sent to the local pubs in their assigned groups. To rule out the inter-group bias, all groups visited specific pubs at certain nights of the week when there was student gathering. The subjects spent approximately $3 \mathrm{~h}$ in relatively highly smoky area of the pub whilst drinking only non-alcoholic beverages. They were supervised by a staff member throughout. In case that there was a drop in the crowd density of the pub, they were instructed to quickly move into a busier pub in the neighborhood. Immediately after the pub visit, all subjects were transferred to the study center and post-sampled for peripheral blood and sputum.

\section{Personal Air Monitoring}

Personal breathing zone air samples were collected by drawing air through teflon PTFE filters [pore size, $2.0 \mu \mathrm{m}$ ] (Omega Specialty Instrument Co. Chelmsford, MA) installed in a SKC plastic cyclone (SKC limited, Eighty Four, PA), connected to a pre-charged pocket pump at a flow rate of $2.2 \mathrm{~L} / \mathrm{min}$. The unit collects respirable particulates with an aerodynamic diameter of $4.0 \mu \mathrm{m}$ at a cut off point of 50\% (25). The particulates were extracted from the filters by sonication with acetonitril and subsequently, analyzed for a spectrum of PAH by high performance liquid chromatography with fluorescence detection (HPLC-FD) (25). 


\section{Peripheral Blood}

Twenty milliliter venous blood was drawn into a heparinized Venoject ${ }^{\oplus} I$ tube (Terumo Europe N.V., Leuven, Belgium). Lymphocyte fraction was separated using the LeucoSep® tubes (Greiner GmbH, Frickenhausen, Germany) according to the instructions of the manufacturer. Isolated PBL were stored at $-70^{\circ} \mathrm{C}$ until further analysis.

\section{Induced Sputum}

Sputum induction and processing were done as described earlier (23). Briefly, after pretreatment with inhalatory salbutamol [200 $\mu \mathrm{g}$ ], subjects inhaled ultrasonically nebulized $4.5 \%$ saline delivered from an Ultra-Neb ${ }^{\mathrm{TM}} 2000$ (De Vilbiss, Somerset, PA) for a period of 3 $\times 7$ min with 5-min intervals. During the intervals, subjects rinsed their mouth, gargled the throat and then, coughed up the produced expectorate into a 50-ml Greiner tube (Greiner $\mathrm{GmbH}$ ) placed on ice. Additionally, they were instructed to cough up the available expectorate at any moment irrespective of the time of induction. Induction was terminated at the end of 21 min of inhalation, or as soon as a sufficient amount of sputum [5 ml] was obtained. Samples were processed by adding $0.1 \%$ Sputolysine (Calbiochem-Novabiochem Corp., La Jolla, CA) [equal to 4 volumes of the samples], followed by incubation in a shaking water bath for 15 $\min$ at $37^{\circ} \mathrm{C}$. The samples were intermittently vortexed for $15 \mathrm{sec}$ and aspirated with a $25-\mathrm{ml}$ pipette. To quench the activity of the Sputolysine, 4 volumes of phosphate buffered saline (PBS), pH 7.4 were added and incubation went by for another $5 \mathrm{~min}$. The resulting homogenates were centrifuged at $725 \times \mathrm{g}$ for $10 \mathrm{~min}$ at $4^{\circ} \mathrm{C}$. Supernatants were discarded and the pellets were resuspended in $2 \mathrm{ml}$ PBS from which $100 \mu \mathrm{l}$ aliquots were used for cytological examination and the reminders were re-pelleted to be preserved at $-70{ }^{\circ} \mathrm{C}$ until DNA isolation. Determinations of cell viability [according to the trypan blue exclusion technique] and total cell counts were carried out using $10 \mu \mathrm{l}$ of the cell suspensions in a standardized haemocytometer. From the remaining cell suspensions, aliquots of $30 \times 10^{3}$ cells [diluted in PBS to a final volume of $300 \mu \mathrm{l}$ ] were cytocentrifuged (Shandon ${ }^{\odot}$, Cheshire, UK) at $1500 \mathrm{ppm}$ for $5 \mathrm{~min}$ onto Polysine ${ }^{\mathrm{TM}}$ microslides (E. Merck Nederland B.V., Amsterdam, the Netherlands). The slides were stained with May-Grünwald Giemsa and cell differentiation was done by counting 500 non-squamous cells per slide.

\section{DNA Isolation}

Isolation of DNA was performed as described earlier with some modifications (24). Briefly, cell pellets were thawed and then, lysed with $400 \mu \mathrm{l}$ of Proteinase $\mathrm{K}[50 \mu \mathrm{g} / \mathrm{ml}$ and $1 \mathrm{mg} / \mathrm{ml}$ for PBL and induced sputum, respectively] in SET/SDS [100 $\mathrm{mM} \mathrm{NaCl}, 20 \mathrm{mM}$ EDTA, 50 $\mathrm{mM}$ Tris, $0.5 \%$ sodium dodecyl sulfate, $(\mathrm{pH} 8.0)$ ] at $37^{\circ} \mathrm{C}$, overnight. DNA was isolated by repetitive extraction with phenol/chloroform/isoamyl alcohol [25:24:1] and chloroform/isoamyl alcohol [24:1] and precipitated with two volumes of $100 \%$ cold ethanol 
and 1/30 volume of $3 \mathrm{M}$ sodium acetate ( $\mathrm{pH}$ 5.3). Precipitated DNA was rinsed with $70 \%$

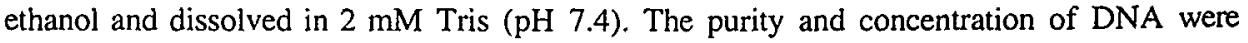
determined spectrophotometrically by absorbance at 230,260 and $280 \mathrm{~nm}\left[\mathrm{~A}_{230 / 260}:-0.4\right.$, $\left.A_{260280}:-1.8\right]$ and afterwards, its concentration was adjusted to $2 \mathrm{mg} / \mathrm{ml}$.

\section{${ }^{32}$ P-postlabeling Assay}

The ${ }^{32} \mathrm{P}$-postlabeling assay was done as described earlier (23). Briefly, DNA [5 $\mu \mathrm{g}$ ] was digested into deoxyribonucleoside $3^{\prime}$-monophosphates by incubation with micrococcal endonuclease [0.5 U] and spleen phosphodiesterase $[3.3 \mu \mathrm{g}]$ for $3 \mathrm{~h}$ at $37^{\circ} \mathrm{C}$. Half of the digest was treated with NP1 $[7.3 \mu \mathrm{g}]$ for $40 \mathrm{~min}$ at $37^{\circ} \mathrm{C}$. The reaction was terminated by adding $0.5 \mathrm{M}$ Tris and labeling was performed using $\mathrm{AT}-\gamma-{ }^{32} \mathrm{P}[50 \mu \mathrm{Ci}]$ in the presence of T4-polynucleotide kinase $[5.8 \mathrm{U}]$ for $30 \mathrm{~min}$ at $37^{\circ} \mathrm{C}$. Subsequently, thin layer chromatography was done on polyethyleneimine (PEI) -cellulose sheets (Macherey Nagel, Düren, Germany) with the following solvent systems: $\mathrm{D}_{1}, 1 \mathrm{M} \mathrm{NaH} \mathrm{PO}_{4}, \mathrm{pH} 6.5 ; \mathrm{D}_{2}, 8.5 \mathrm{M}$ Urea, 5.3 $\mathrm{M}$ Lithium formate, $\mathrm{pH} 3.5 ; \mathrm{D}_{3}, 1.2 \mathrm{M}$ Lithium chloride, $0.5 \mathrm{M}$ Tris, 8.5 Urea, $\mathrm{pH}$ $8.0 ; \mathrm{D}_{4}, 1.7 \mathrm{M} \mathrm{NaH}_{2} \mathrm{PO}_{4}, \mathrm{pH}$ 6.0. Detailed information on the efficiency of NP1 digestion and ATP excess is available in ref. (23). To quantify the nucleotides, the remaining DNA digest was labeled with AT $-\gamma_{-}{ }^{32} \mathrm{P}[15 \mu \mathrm{Ci}]$ under the same conditions as described above. It was then chromatographed one-dimensionally on PEI-cellulose sheet (Merck, Darmstadt, Germany) with a solvent system of $0.12 \mathrm{M} \mathrm{NaH}_{2} \mathrm{PO}_{4}, \mathrm{pH} 6.8$. For standardization, control samples of $\left[{ }^{3} \mathrm{H}\right] \mathrm{BPDE}$ modified DNA with known modification levels [ 1 adduct per $10^{7}$ and $10^{8}$ unmodified nucleotides] were parallelly run in all experiments. Quantification was done using a phosphor imager (Molecular Dynamics ${ }^{\mathrm{TM}}$, Sunnyvale, $\mathrm{CA}$ ) with a lower detection limit of 1 adduct per $10^{9}$ nucleotides.

\section{Statistical Analysis}

Results were expressed as mean \pm standard error. All variables at pre-exposure time were compared with their respectives at post-exposure time by the Wilcoxon signed rank test. Relationships between different variables were explored by the Spearman rank correlation analysis. Statistical significance was considered at $\mathrm{P} \leq 0.05$. 


\section{RESULTS}

\section{Ambient Air Concentrations of PAH and Personal Dosimetry Data}

Table 1 summarizes the results of personal air monitoring in each group as well as overall groups of this study population. Distribution of the concentrations of individual and total $\mathrm{PAH}$ and their respective respirable doses are presented in Figure 1 [the amount of individual or total PAH extracted from the ETS-exposed filters was considered as the respective respirable dose]. For benzo[a]anthracene, benzo[b]fluoranthene, benzo[k]fluoranthene, benzo[a]pyrene and total PAH, the respirable doses were linearly but non-significantly related to the total volume of air flown into the filters. For chrysene, this relationship was statistically significant $(r=0.6, P=0.04)$. Adjusting the data for air volume, the coefficients of variation for respirable doses of individual and total $\mathrm{PAH}$ were as follows, benzo[a]anthracene, 27\%; chrysene, 23\%; benzo[b]fluoranthene, $23 \%$; benzo[k]fluoranthene, $19 \%$; benzo[a]pyrene, $22 \%$; total PAH, $21 \%$. To verify the respirable dosimetry data, control air samples were taken from two different indoor environments [a living room and an office] for the same duration of time and with the identical devices. In neither case, was there any detectable individual or total PAH in the extracted filters.

Table 1. Summary data of the personal air monitoring

\begin{tabular}{|c|c|c|c|c|c|c|c|c|c|c|}
\hline & \multicolumn{2}{|c|}{$\begin{array}{c}\text { Group } I^{\prime} \\
(n=3)\end{array}$} & \multicolumn{2}{|c|}{$\begin{array}{c}\text { Group II } \\
(n=4)\end{array}$} & \multicolumn{2}{|c|}{$\begin{array}{c}\text { Group III } \\
(n=4)\end{array}$} & \multicolumn{2}{|c|}{$\begin{array}{c}\text { Group IV } \\
(n=4)\end{array}$} & \multicolumn{2}{|c|}{$\begin{array}{c}\text { Overall Group } \\
(n=15)\end{array}$} \\
\hline & 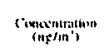 & $\begin{array}{l}\operatorname{lins} \\
\text { ingi }\end{array}$ & 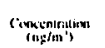 & (1) & 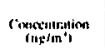 & $\begin{array}{l}\text { Dancis } \\
\text { (n) }\end{array}$ & 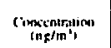 & $\begin{array}{l}\text { lane } \\
\text { angi }\end{array}$ & 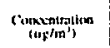 & 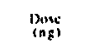 \\
\hline $\mathrm{B}[\mathrm{a}] \mathrm{A}^{2}$ & $1.3 .2 \pm 1.6$ & $4.3 \pm 0.5$ & $10.7 \pm 1.4$ & $3.4 \pm 0.5$ & $12.9 \pm 1.5$ & $4.4 \pm 0.5$ & $12.6 \pm 2.5$ & $4.5 \pm 0.9$ & $12.3 \pm 0.9$ & $4.2 \pm 0.3$ \\
\hline Chryscne & $18.5 \pm 0.3$ & $0.1 \pm 0.1$ & $14.7 \pm 1.5$ & $4.7 \pm 0.5$ & $19.8 \pm 1.5$ & $6.7 \pm 0.5$ & $19.4 \pm 3.1$ & $7.0 \pm 1.1$ & $18.1 \pm 1.1$ & $6.1=0.4$ \\
\hline$B[b] F^{3}$ & $4.9 \pm 0.8$ & $1.6 \pm 0.3$ & $3.8 \pm 0.1$ & $1.2 \pm 0.03$ & $5.0 \pm 0.4$ & $1.7 \pm 0.2$ & $4.5 \pm 0.7$ & $1.6 \pm 0.2$ & $4.5 \pm 0.3$ & $1.5 \pm 0.1$ \\
\hline$B[k] F^{4}$ & $1.2 \pm 0.1$ & $0.4 \pm 0.1$ & $0.9 \pm 0.1$ & $0.3 \pm 0.02$ & $1.0 \pm 0.1$ & $0.3 \pm 0.04$ & $1.1 \pm 0.1$ & $0.4 \pm 0.03$ & $1.0 \pm 0.1$ & $0.4 \pm 0.1$ \\
\hline$B[a] P^{s}$ & $6.8 \pm 0.3$ & $2.2 \pm 0.1$ & $6.0 \pm 0.5$ & $1.9 \pm 0.2$ & $6.5 \pm 1.0$ & $2.2 \pm 0.3$ & $6.2 \pm 1.0$ & $2.2 \pm 0.4$ & $6.3=0.4$ & $2.1 \pm 0.1$ \\
\hline Total PAH & $44.6 \pm 3.0$ & $14.7 \pm 1.0$ & $36.1 \pm 2.8$ & $11.6 \pm 0.9$ & $45.2 \pm 4.1$ & $15.3 \pm 1.3$ & $43.8 \pm 6.4$ & $15.7 \pm 2.3$ & $42.3 \pm 2.2$ & $14.3 \pm 0.8$ \\
\hline Volume & \multicolumn{2}{|c|}{$173 \pm 1.0$} & \multicolumn{2}{|c|}{$168 \pm 0.3$} & \multicolumn{2}{|c|}{$178 \pm 0.9$} & \multicolumn{2}{|c|}{$188 \pm 0.3$} & \multicolumn{2}{|c|}{$177 \pm 7.9$} \\
\hline
\end{tabular}

'Results are expressed as mean $\pm S E M$.

${ }^{2}$ Benzo[a]anthracenc.

'Benzo[b]fluoranthene.

"Benzo[k]fluoranthene.

'Benzo[a]pyrene.

"Total volume of air flown into the filter (L). 

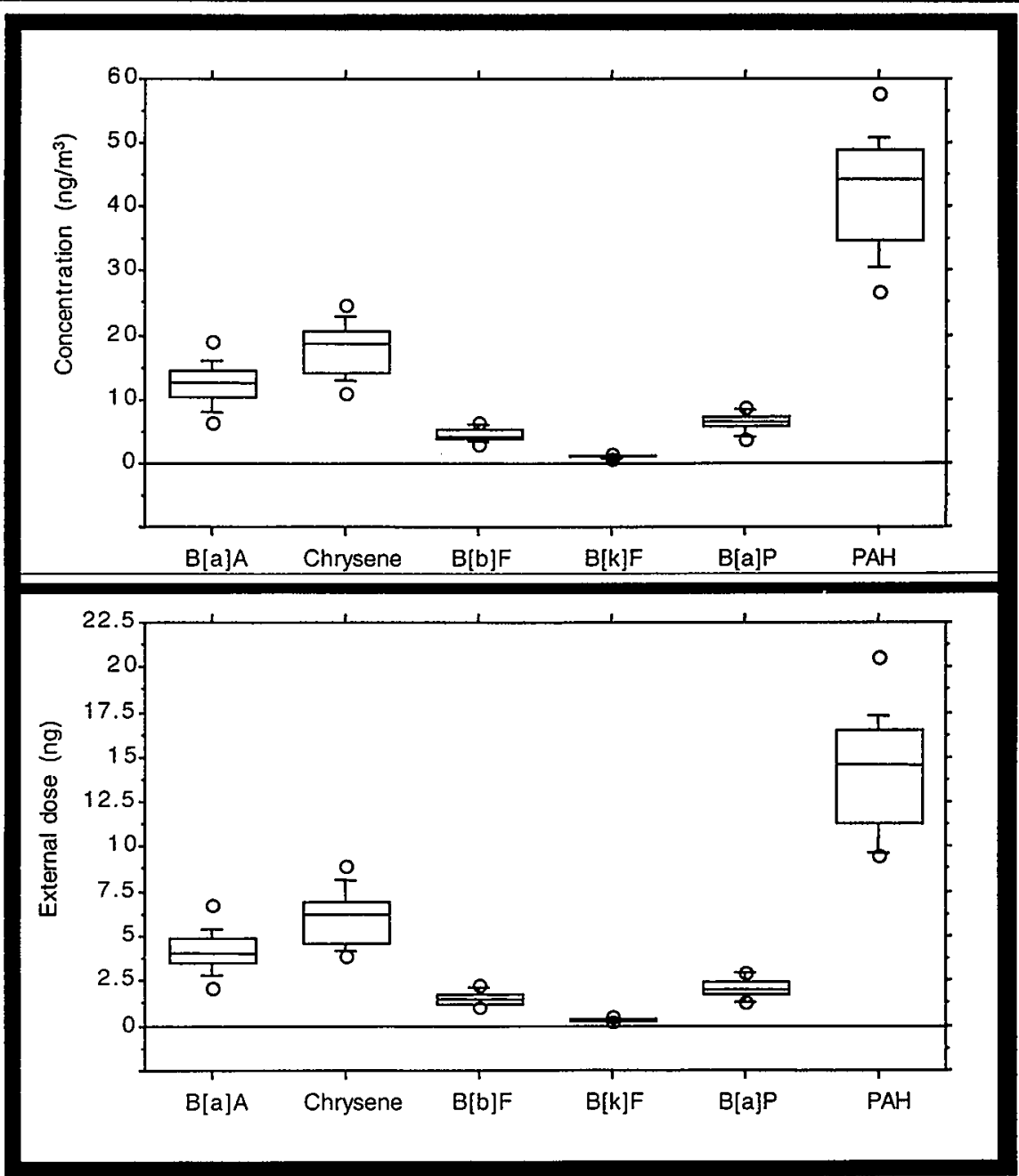

Fig.1. Distribution of the concentrations of individual and total PAH in the ambient air of the pubs and their respective respirable doses for the overall study group. The lower and upper edges of the boxes, the $25^{\text {th }}$ and the $75^{\text {th }}$ percentiles, respectively. - within the boxes, the medians. Lower and upper bars, the $10^{\text {th }}$ and the $90^{\text {th }}$ percentiles, respectively. 0 . Individual values $<10^{\text {th }}$ or $>90^{\text {th }}$ percentiles. Compound abbreviations are defined in the text.

\section{Success Rate for Sputum Induction}

Sputum induction was well tolerated by all subjects and no troublesome symptoms occurred throughout the procedure. Thirteen of 15 individuals at pre-exposure time and fourteen of them at post-exposure time could produce sufficient amount of sputum for further analysis [Tab. 2]. 


\section{Cytological Examinations and DNA Yield of Induced Sputum}

Cellular characteristics of induced sputum samples at pre- and post-exposure times $\left[T_{0}\right.$ and $T_{1}$, respectively] are presented in Table 2 . Overall, there was no significant difference in induced sputum cytology at $T_{0}$ as compared to $T_{1}$; total cell count $\left(7.7 \pm 1.9\right.$ versus $6.8 \pm 2.0 \times 10^{6}$; $\mathrm{P}=0.4)$; cell viability $(73.1 \pm 4.3$ versus $79.5 \pm 5.4 \% ; \mathrm{P}=0.3)$; non-squamous cells $(82.8 \pm$ 4.0 versus $89.0 \pm 2.7 \% ; \mathrm{P}=0.09$ ). The overall non-squamous cell composition was as follows, bronchoalveolar macrophages, $80 \pm 7 \%$; neutrophils, $11 \pm 2 \%$; bronchoepithelial cells, $8.5 \pm 2.1 \%$; lymphocytes, $0.3 \pm 0.1 \%$; metachromatic cells, $0.2 \pm 0.1 \%$. Also, DNA yield of the induced sputum samples at $T_{0}$ did not differ from that at $T_{1}(29.4 \pm 5.9$ versus $35.1 \pm 7.8 \mu \mathrm{g} ; \mathrm{P}=0.5$ ).

Table 2. Sputum induction, cytology, DNA yield and DNA adduct dosimetry at pre- and post-exposure times

\begin{tabular}{|c|c|c|c|}
\hline & & Pre-exposure & Post-exposure \\
\hline \multicolumn{2}{|c|}{ Sputum induction (success/failure) } & $13 / 2$ & $14 / 1$ \\
\hline \multicolumn{2}{|l|}{ Total cell count $\left(\times 10^{6}\right)^{\prime}$} & $7.7 \pm 1.9$ & $6.8 \pm 2.0$ \\
\hline \multicolumn{2}{|l|}{ Viability $(\%)^{\prime}$} & $73.1 \pm 4.3$ & $79.5 \pm 5.4$ \\
\hline \multicolumn{2}{|l|}{ Non-squamous cells $(\%)^{\prime}$} & $82.8 \pm 4.0$ & $89.0 \pm 2.7$ \\
\hline \multicolumn{2}{|l|}{ DNA yield $(\mu \mathrm{g})^{\prime}$} & $29.4 \pm 5.9$ & $35.1 \pm 7.8$ \\
\hline \multirow{4}{*}{ Qualitative DNA adducts ${ }^{2}$} & Spot $1^{3}$ & $\mathrm{ND}^{4}$ & 3 \\
\hline & Spot 2 & 4 & 2 \\
\hline & Spot 3 & 10 & 11 \\
\hline & DRZ & 3 & 4 \\
\hline \multirow{5}{*}{ Quantitative DNA adducts' } & Spot $1\left(/ 10^{x} n t\right)$ & $\mathrm{ND}^{4}$ & $0.29 \pm 0.04$ \\
\hline & Spot $2\left(/ 10^{x} n t\right)$ & $0.40 \pm 0.14$ & $0.59 \pm 0.27^{5}$ \\
\hline & Spot $3\left(/ 10^{8} \mathrm{nt}\right)$ & $0.69 \pm 0.17$ & $0.52 \pm 0.13$ \\
\hline & $\mathrm{DRZ}\left(/ 10^{k} \mathrm{nt}\right)$ & $2.29 \pm 0.7$ & $2.37 \pm 1.51$ \\
\hline & Total $\left(/ 10^{\mathrm{x}} \mathrm{nt}\right)$ & $1.40 \pm 0.44$ & $1.57 \pm 0.69$ \\
\hline
\end{tabular}

'Expressed as Mean \pm SEM.

${ }^{2}$ Number of samples showing the respective DNA adduct spots.

'Co-migrated with standard BPDE-DNA adduct.

Not determined.

'Statistically significant as compared to spot 2 at pre-exposure time. 


\section{DNA Adducts in Induced Sputum}

Figure $2[\mathrm{~A}, \mathrm{~B}]$ shows the representative chromatograms of ${ }^{32} \mathrm{P}$-postlabelled DNA adducts from an individual at pre- and post-exposure times $\left[\mathrm{T}_{0}\right.$ and $\mathrm{T}_{1}$, respectively]. Overall, the DNA adduct profile consisted of three distinct spots [spot 1,2,3] and a faint diagonal radioactive zone (DRZ) [Tab. 2]. Spot 1 was present only at $T_{1}$ and co-migrated with standard ( \pm )-antibenzo[a]pyrene diol epoxide (BPDE) -DNA adduct spot [Fig. 2 B, C]. The other two spots and the DRZ were observed both at $T_{0}$ and $T_{1}$. Qualitatively, spot 1 was observed in the adduct maps of 3 individuals at $T_{1}$. Spot 2 was seen in the adduct maps of 4 and 2 individuals at $T_{0}$ and $\mathrm{T}_{1}$, respectively. Spot 3 was the most prevalent one and appeared in the adduct maps of 10 and 11 individuals at $T_{0}$ and $T_{1}$, respectively. The respective number of individuals at $T_{0}$ and $T_{1}$ who showed a DRZ in their adduct maps, were 3 and 4 . Quantitatively, there was no significant difference in spot 3 and DRZ between $T_{0}$ and $T_{1}$. The spot 2 was significantly enhanced at $T_{1}$ as compared to $T_{0}(P=0.04)$. There was only a marginal enhancement in the overall spots and DRZ [considered as total level of adducts] at $T_{1}$ as compared to $T_{0}(1.57 \pm$ 0.69 versus $1.40 \pm 0.44 / 10^{8}$ nucleotides, $\left.\mathrm{P}=0.7\right)$. Total level of adducts varied in the ranges of $0.28-4.1 / 10^{8}$ nucleotides at $\mathrm{T}_{0}$ and $0.30-4.5 / 10^{8}$ nucleotides at $\mathrm{T}_{1}$. For verification, induced sputum samples from three known smokers were parallelly analyzed, as well. All the three, revealed an intense DRZ in their adduct maps and had a total adduct level of $2.92 \pm 0.9 / 10^{8}$ nucleotides.

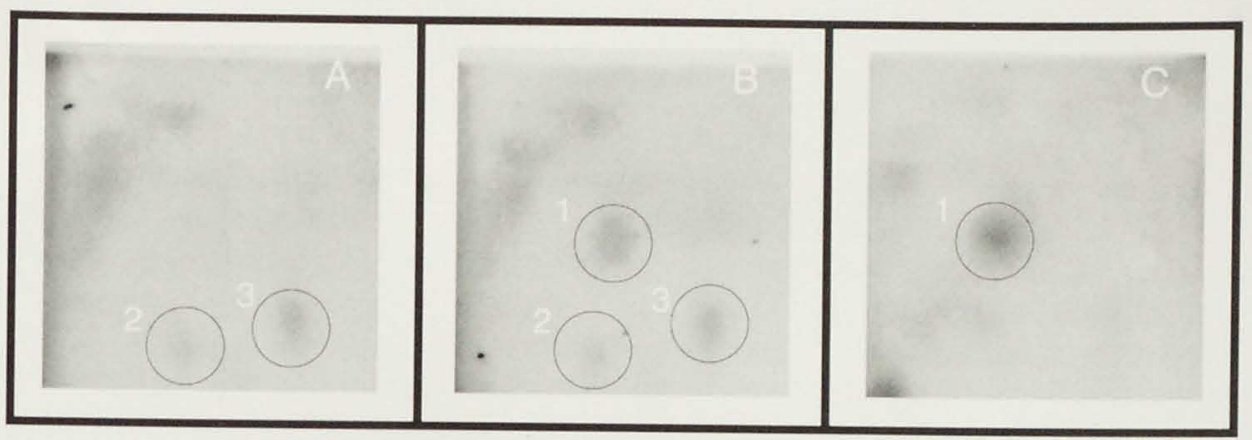

Fig. 2. Representative chromatograms of the ${ }^{32} \mathrm{P}$-postlabelled DNA adducts in induced sputum of a non-smoker at pre- and post-exposure times (A, B, respectively), and the BPDE-DNA adduct standard $\left[1\right.$ adduct $/ 10^{8}$ nucleotides] (C). Spot 1,2 and 3 are encircled. The radioactivity in the upper left-hand corner was also observed at the same location in non-modified calf thymus DNA and therefore, considered as background.

Overall, there was no detectable level of adducts in PBL of most individuals either at $\mathrm{T}_{0}$ or at $\mathrm{T}_{1}$; only 3 samples had fairly quantifiable DNA adducts [just above the detection limit of our assay] with no correlation with induced sputum DNA adducts. Further, there was no relationship between DNA adduct dosimetry data in induced sputum or PBL and the respirable doses of individual or total $\mathrm{PAH}$. 
Moreover, DNA adduct analysis in PBL produced no conclusive results as there was almost no detectable level of adducts in this cell type either before or after the experimental exposure to ETS. This is not surprising because previous studies by others also failed to demonstrate any increase in DNA adduct levels in PBL or total white blood cells after exposure to ETS $(32,33)$. Also, applying a much more intense and controlled exposure condition $(8 \mathrm{~h}$ in a confined chamber), Holz at el. found similar results in peripheral blood monocytes (34). Taken together, it seems that the total or fractionated blood cells are not a choice of preference for the surrogacy of an organ like the lung. Understandingly, the circulating blood cells are exposed to multiple sources of carcinogens, which enter the body via different routes e.g., inhalation, ingestion and dermal absorption. In addition, they have varying biotransformational and DNA repair capacity and various life spans $(29,30,35)$. Thus, they may reflect an integrated DNA adduct burden for the entire body but not for an individual organ (36).

Lastly, our DNA adduct dosimetry data were only indirectly confirmed by personal air monitoring data, which showed the presence of carcinogenic PAH in the ambient air of the pubs. Albeit, there was no linear relationship between respirable doses of individual or total PAH and DNA adduct levels in induced sputum or PBL. Of course, it should be taken into account that exposure to carcinogen is only a preliminary step in carcinogenesis, whereas DNA adduct formation is an intermediate one. Unlike exposure to carcinogen, formation of DNA adducts can be affected by various parameters that are different within and between the individuals $(17,37)$. Therefore, it is conceivable that the external dosimetry and DNA adduct data may not correspond to each other especially in small study populations.

In summary, we have demonstrated that DNA adduct analysis in induced sputum may potentially be used as an integral means to assess exposure to ETS. From the standpoint of public health, our findings warrant further investigations to evaluate the health consequences of exposure to ETS in different indoor environments including the occupational settings.

$* * * * * * * * *$ 


\section{REFERENCES}

1. US Environmental Protection Agency (1992) Respiratory health effects of passive smoking: Jung cancer and other disorders. US Environmental Protection Agency, Office of Health and Environmental Assessment, Office of Research and Development, Washington D.C., EPA/600/6-90/006F.

2. Spitzer, W.O., Lawrence V., Dales R., Hill G., Archer M.C., Clark P., Abenhaim L., Hardy J., Sampalis J., Pinfold S.P. and ct al. (1990) Links between passive smoking and disease: a best-evidence synthesis. A report of the Working Group on Passive Smoking. Clin Invest Med, 13, 17-42.

3. Tredanicl, J., Boffetta P., Saracci R. and Hirsch A. (1994) Exposure to environmental tobacco smoke and risk of lung cancer: the epidemiological evidence. Eur Respir J, 7, 1877-1888.

4. Leonard, C.T. and Sachs D.P.L. (1999) Environmental tobacco smoke and lung cancer incidence. Curr Opinion Pul Med, 5, 189-193.

5. Witschi, H., Pinkerton K.E., Coggins C.R.E., Penn A. and Gori G.B. (1995) Environmental tobacco smoke: experimental facts and societal issues. Fundament Appl Toxicol, 24, 3-12.

6. Jaakkola, M.S. and Jaakkola J.J. (1997) Assessment of exposure to environmental tobacco smoke. Eur Respir J, 10, 2384-2397.

7. National Research Council (1986) Executive summary. In Committee on Passive Smoking Board on Environmental Studies and Toxicology (ed.), Environmental robacco smoke. Measuring exposure axd assessing health effects. National Academy Press, Washington D.C., pp. 1-12.

8. Scherer, G. and Richter E. (1997) Biomonitoring exposure to environmental tobacco smoke (ETS): a critical reappraisal. Hum Exp Toxicol, 16, 449-459.

9. National Research Council (1986) Assessing exposures to environmental tobacco smoke using biological markers. In Committee on Passive Smoking Board on Environmental Studies and Toxicology (cd.), Environmental tobacco smoke. Measuring exposure and assessing health effects. National Academy Prcss, Washington D.C., pp. 133-159.

10. National Research Council (1986) Assessing exposures to environmental tobacco smoke in the external environment. In Committee on Passive Smoking Board on Environmental Studies and Toxicology (cd.), Environmental tobacco smoke. Measuring exposure and assessing health effects. National Academy Press, Washington D.C., pp. 69-100.

11. International Agency for Research on Cancer (1986) Tobacco smoking. Monographs on the evaluation of the carcinogenic risk of chemicals to humans. Vol. 38. International Agency for Research on Cancer, Lyon (France), pp. 37-375.

12. International Agency for Research on Cancer (1994) Monographs on the evaluation of the carcinogenic risk of chemicals to humans. Overall evaluations of carcinogenicity: An updating of IARC monographs volumes 1-60. International Agency for Research on Cancer, Lyon (France).

13. Hecht, S.S. (1996) Carcinogenesis due to tobacco: molecular mechanisms. In Bcrtino, J.R. (ed.), Encyclopedia of cancer. Academic Press, San Diego (CA), pp. 220-232.

14. Harris, C.C. (1991) Chemical and physical carcinogenesis: advances and perspectives for the $1990 \mathrm{~s}$. Cancer Res, 51, 5023s-5044s.

15. Hemminki, K. (1993) DNA adducts, mutations and cancer. Carcinogenesis, 14, 2007-2012.

16. Denissenko, M.F., Pao A., Tang M. and Pfeifer G.P. (1996) Preferential formation of benzo[a]pyrene adducts at lung cancer mutational hotspots in P53. Science, 274, 430-432. 
17. Wilcosky, T.C. and Griffith J.D. (1990) Application of biological markers. In Hulska, B.S., Wilcosky, T.C. and Griffith, J.D. (cds), Biological markers in epidemiology. Vol. 1. Oxford University Press, New York, pp. 16-27.

18. Wilcosky, T.C. (1990) Criteria for selecting and evaluating markers. In Hulska, B.S., Wilcosky, T.C. and Griffith. J.D. (eds), Biological markers in epidemiology. Oxford University Press, New York, pp. 28-55.

19. Poirier, M.C. and Weston A. (1996) Human DNA adduct measurements: state of the art. Environ Health Perspect, 104 Suppl 5, 883-893.

20. Phillips, D.H. (1996) DNA adducts in human tissues: biomarkers of exposure to carcinogens in tobacco smoke. Environ Health Perspect, 104 Suppl 3, 453-458.

21. Butkicwicz, D.. Grzybowska E., Hemminki K., Ovrebo S., Haugen A., Motykiewicz G. and Chorazy M. (1998) Modulation of DNA adduct levels in human mononuclear whitc blood cells and granulocytes by CYPIAI, CYP2D6 and GSTMI genetic polymorphisms. Mutat Res, 415, 97-108.

22. Knudsen, L.E., Ryder L.P. and Wasserman K. (1992) Induction of DNA repair synthesis in human monocytes/B-lymphocytes compared with T-lymphocyles after exposure to $\mathrm{N}$-acetoxy- $\mathrm{N}$ acetylaminofluorene and dimcthylsulfate in vitro. Carcinogenesis, 13, 1285-1287.

23. Nia, A.B., Maas L.M., Van Breda S.G., Curfs D.M., Kleinjans J.C., Wouters E.F. and Van Schooten F.J. (2000) Applicability of induced sputum for molecular dosimetry of exposure to inhalatory carcinogens: ${ }^{32} \mathrm{P}$-postlabcling of lipophilic DNA adducts in smokers and nonsmokers. Cancer Epidemiol Biomarkers Prev, 9, 367-372.

24. Nia, A.B., Maas L.M., Brouwer E.M., Kleinjans J.C. and Van Schooten F.J. (2000) Comparison between smoking-related DNA adduct analysis in induced sputum and peripheral blood lymphocytes. Carcinogenesis, 21, 1335-1340.

25. Eller, P.M. (1984) NIOSH Manual of analytical methods. Vol 2. US Department of health and Human Services, Public Health Scrvice, Center for Disease Control, National Institute of Occupational Safety and Health. Division of Physical sciences and Engineering, Cincinnati, $\mathrm{OH}$.

26. Chuang, J.C., Mack G.A., Kuhlman M.R. and Wilson N.K. (1991) Polycyclic aromatic hydrocarbons and their derivatives in indoor and outdoor air in an eight-home study. Atmos Environ, 25, 369-380.

27. Guerin, M.R., Jenkins R.A. and Tomkins B.A. (1992) The chemistry of environmental tobacco smoke: composition and measurement. Lewis Publishers, London.

28. Smith, L.E.. Denissenko M.F., Bennett W.P., Li H., Amin S., Tang M. and Pfeifer G.P. (2000) Targeting of lung cancer mutational hotspots by polycyclic aromatic hydrocarbons. $J$ Natl Cancer Inst, 92, 803-811.

29. Savela, K. and Hemminki K. (1991) DNA adducts in lymphocytes and granulocytes of smokers and nonsmokers detected by the ${ }^{32} \mathrm{P}$-postlabelling assay. Carcinogenesis, 12, 503-508.

30. Holz, O., Krause T. and Rudiger H.W. (1991) Differences in DNA adduct formation between monocytes and lymphocytes after in vivo incubation with benzo[a]pyrene. Carcinogenesis, 12, 2181-2183.

31. Kulkarni. M.S., Angerman-Stewart J. and Anderson M.W. (1984) Detection of in vivo DNA repair synthesis in mouse liver and lung induced by treatment with benzo[a]pyrene or 4-nitroquinoline 1-oxide. Cancer Res, 44, 1547-1550.

32. Scherer, G., Conze C., Tricker A.R. and Adlkofer F. (1992) Uptake of tobacco smoke constituents on exposure to environmental tobacco smoke (ETS). Clin linvest, 70, 352-367.

33. Binkova, B. (1995) DNA adducts and personal monitoring of carcinogenic polycyclic aromatic hydrocarbons in an environmentally exposed population. Carcinogenesis, 16, 1037-1046. 
34. Holz, O., Krause T., Scherer G., Schmidt-Preuss U. and Rudiger H.W. (1990) ${ }^{32}$ P-postlabelling analysis of DNA adducts in monocytes of smokers and passive smokers. Int Arch Occup Environ Health, 62, 299-303.

35. Boggs, D.R. and Winkelstein A. (1983) White Cells Manual. F. A. Davis, Philadelphia (PA).

36. Eder, E. (1999) Interindividual variations of DNA adduct levels in humans. Mutat Res, 424, 249-261.

37. Hulka, B. (1990) Overvicw of biological markers. In Hulka, B.S., Wilcosky, T. and Griffith, J. (eds), Biological markers in epidemiology. Oxford University Press, New York, pp. 3-15. 


\section{CHAPTER 6}

SMOKING-INDUCED OXIDATIVE STRESS 


\title{
A multi-biomarker approach to study the effects of smoking on oxidative DNA damage
} and repair and antioxidative defense mechanisms

\author{
A. Besarati Nia', F.J. Van Schooten', P.A.E.L. Schilderman', T.M.C.M. De Kok', G.R. Haenen², \\ M.H.M. Van Herwijnen', E. Van Agen', D. Pachen', J.C.S. Kleinjans'
}

'Department of Health Risk Analysis and Toxicology, Maastricht University, Maastricht, The Nethcrlands 'Department of Pharmacology, Maastricht University, Maastricht, The Netherlands

\begin{abstract}
We investigated the effects of smoking-induced oxidative stress in healthy volunteers (21 smokers versus 24 non-smokers) by quantifying various markers of oxidative DNA damage and repair, and antioxidative defense mechanisms. Lymphocytic 7-hydroxy-8-oxo-2'deoxyguanosine (8-oxo-dG) levels measured by high performance liquid chromatography with electrochemical detection (HPLC-ECD), were significantly lower in smokers as compared to non-smokers $\left(38.6 \pm 5.2\right.$ versus $\left.50.9 \pm 4.6 / 10^{6} \mathrm{dG}, \mathrm{P}=0.05\right)$. The levels of oxidized pyrimidine bases in lymphocytes of smokers quantified by the endonuclease IIImodified comet assay, were non-significantly lower than those of non-smokers (\% DNA in tail, $13 \pm 3$ versus $14 \pm 2$; tail length, $69 \pm 13$ versus $96 \pm 10$; tail moment, $6416 \pm 1220$ versus $7545 \pm 1234$ ). Urinary excretion levels of 8 -hydroxy-2'-deoxyguanosine (8-OH-dG) assessed by enzyme-linked immunosorbent assay (ELISA), did not differ significantly between smokers and non-smokers ( $197 \pm 31$ versus $240 \pm 33 \mathrm{ng}$ /body mass index, $\mathrm{P}=0.3$ ). Overall DNA repair activity expressed as unscheduled DNA synthesis (UDS) in blood leukocytes, was not significantly different between smokers and non-smokers $(2.9 \pm 0.3$ versus $3.3 \pm 0.3, \mathrm{P}=0.4$ ). Plasma antioxidative capacity measured by the Trolox equivalent antioxidant capacity (TEAC) assay, was slightly higher in smokers as compared to nonsmokers ( $440 \pm 16$ versus $400 \pm 15 \mu \mathrm{M}$ Trolox equivalent, $\mathrm{P}=0.09$ ) and it was significantly related to lymphocytic 8 -oxo-dG levels $(r=0.4, \mathrm{P}=0.001$ ). Genotyping of human $8-\mathrm{OH}-\mathrm{dG}$ glycosylase/apurinic lyase ( $h O G G I$ ) and glutathione $S$-transferase Ml (GSTMI) showed that a polymorphism in either or both of the two genes does not affect any of the quantified biomarkers. We conclude that oxidative stress imposed by cigarette smoking has low impact upon certain pathways involved in DNA damage and antioxidative defense system.
\end{abstract}

Based on the manuscript published in:

"Carcinogenesis (2001) 22, 101-107" 


\section{Chapter Six}

\section{Smoking-induced oxidative stress}

\section{INTRODUCTION}

Reactive oxygen species (ROS) is a collective term used for compounds containing partially reduced oxygen and possessing high reactivity with biomolecules e.g., DNA, proteins and lipids (1-5). The ROS are generated during cellular respiration, intra-cellular signal transduction, phagocytosis and metabolism of xenobiotics $(3,6-12)$. Oxidative stress occurs when the cell is subjected to an increased amount of endogenous and/or exogenous ROS $(3,9)$. To counteract the oxidative stress, aerobic organisms have evolved various defense mechanisms (13). Plasma antioxidants are the first line of defense against exogenous oxidative stress, which scavenge the ROS prior to their inter-actions with cellular components (13-15). Plasma antioxidants comprise water-soluble antioxidants: ascorbic acid, uric acid, protein thiols and bilirubin, and lipid-soluble antioxidants: $\alpha-, \beta$-tocopherols, ubiquinol, lycopene, carotenoids and oxycarotenoids (16). A triple enzyme, superoxide dismutase, catalase and glutathione peroxidase, along with a phase II family of enzymes, glutathione $S$-transferases (GSTs), constitute the secondary defensive system against endogenous and/or exogenous oxidative stress. The system reduces ROS to less reactive metabolites and then, to excretable endproducts $(15,17)$. Theoretically, polymorphisms of genes encoding for the abovementioned enzymes may account for inter-individual variability in handling oxidative stress. In humans, a notable polymorphism is GSTMI homozygous allelic loss, GSTMI null genotype, which is prevalent in approximately 50\% of the Caucasians and associated with several types of cancer (18-22). Lastly, a complementary repair system exists in case that ROS escape the first two defense lines and assault the cellular targets $(23,24)$. An example of this system is the 8-hydroxy-2'-deoxyguanosine-glycosylase/apurinic lyase gene (OGGI), which repairs 8oxo-7,8-dihydroguanine (8-oxo-Gua), the most abundant and highly mutagenic ROS-induced DNA lesion (25-33). In Escherchia coli, polymorphic variants of OGGI vary in their enzymatic effectivity to suppress spontaneous mutagenesis (34); assumingly, in humans polymorphism of the homologue gene (hOGGI) might also have a functional impact on the repair of 8-oxo-Gua $(34,35)$. Of most interest is the Ser-Cys polymorphism of hOGGl at codon 326 , which results in encoded enzymes with varying activity (36).

In the present study, we investigated the effects of oxidative stress imposed by cigarette smoking, a well-documented source of ROS (37-39), on various pathways involved in DNA damage and repair as well as antioxidative defense mechanisms. For this purpose, we quantified in a group of smokers as compared to non-smokers [I] levels of 8-oxo-dG in peripheral blood lymphocytes (PBL) by means of reversed phase high performance liquid chromatography with electrochemical detection (HPLC-ECD), [II] levels of oxidized pyrimidine bases by means of endonuclease III-modified comet assay, [III] levels of the repair product of $8-\mathrm{OH}-\mathrm{dG}$ excreted in urine by means of a competitive enzyme-linked immunosorbent assay (ELISA), [V] overall DNA repair activity in blood leukocytes by means of unscheduled DNA synthesis (UDS) assay, [IV] plasma antioxidants scavenging capacity 
by means of Trolox equivalent antioxidant capacity (TEAC) assay and finally, [VI] genetic polymorphisms of GSTMI and hOGGl by means of polymerase chain reaction (PCR) technique.

\section{MATERIAL AND METHODS}

\section{Study Population}

Volunteers were recruited by advertising in the local newspapers. Upon enrollment, every individual signed an informed consent and filled out a comprehensive questionnaire on his/her age, gender, occupation, lifestyle including smoking and drinking behaviors, fresh fruit and vegetable consumption as well as vitamin supplementation, medical history of disease and familial history of cancer. The study population consisted of two groups of healthy smokers $(n=21)$ and lifelong non-smokers $(n=24)$ with an average age of $39 \pm 2.4$ [range, $24-54$ ] years and $34 \pm 1.7$ [range, $23-43$ ] years, respectively. The participants had no occupational exposure to known or suspected sources of ROS, nor any dietary or medicinal vitamin supplementation. Detailed characteristics of the study population are presented in Table 1. The study was approved by the Medical Ethical Commission of Maastricht University.

Table 1. Characteristics of the study population

\begin{tabular}{|l||c||c|}
\hline & Smokers & Non-smokers \\
\hline \hline Number & 21 & 24 \\
\hline Gender (male/female) & $8 / 13$ & $6 / 18$ \\
\hline Age & $39 \pm 2.4$ & $34 \pm 1.7$ \\
\hline Cigarettes/day & $19 \pm 2.0$ & 0 \\
\hline Tar/day & $392 \pm 66$ & 0 \\
\hline Smoking years & $21 \pm 2$ & 0 \\
\hline Pack years & $20 \pm 4$ & 0 \\
\hline
\end{tabular}

Results are expressed as mean \pm SEM. 


\section{Peripheral blood}

Thirty milliliters of venous blood were drawn into heparinized Venoject ${ }^{\oplus} I I$ tubes (Terumo Europe N.V., Leuven, Belgium). Plasma and lymphocyte fractions were isolated according to the standardized gradient centrifugation procedure (40). Part of the isolated lymphocytes was used for immediate analyses, and the remainder was pelleted and preserved at $-80^{\circ} \mathrm{C}$ until DNA isolation.

\section{Urine}

Twenty four-h urine was collected in polyethylene bottles. Volume of the sample was measured, and after agitation, aliquots $[2 \times 1 \mathrm{ml}]$ of the homogenized urine were kept at $-80^{\circ} \mathrm{C}$ until further analysis.

\section{DNA isolation}

DNA isolation was done as described earlier (41). Briefly, cell pellet was lysed with Proteinase $\mathrm{K}[0.2 \mu \mathrm{g} / \mu \mathrm{l}]$ in $1 \% \mathrm{SDS} / 1 \mathrm{mM}$ EDTA, $\mathrm{pH} 8.0$, for $30 \mathrm{~min}$ at $37^{\circ} \mathrm{C}$. To prevent artifactual formation of $8-\mathrm{OH}-\mathrm{dG}$ during extraction procedure, $0.1 \%$ 8-hydroxy-quinoline was added to phenol. Nucleic acids were extracted repeatedly with phenol, phenol:chloroform:isoamyl alcohol [25:24:1] and chloroform:isoamyl alcohol [24:1], precipitated with 0.1 volume of $1 \mathrm{M}$ sodium acetate, $\mathrm{pH} 6.0$ in 2 volumes of $100 \%$ ice-cold ethanol, washed with 1 volume of ethanol $70 \%$ and then, dissolved in $5 \mathrm{mM}$ Tris/1mM EDTA, pH 7.4. The resultant was treated with a RNAse mixture [RNAse A $\{100 \mu \mathrm{g} / \mathrm{ml}\}$ and RNAse $\mathrm{Tl}\{50 \mathrm{U} / \mathrm{ml}\}]$ for $30 \mathrm{~min}$ at $37^{\circ} \mathrm{C}$ and subsequently, the DNA content of the solution was recovered with the abovementioned extraction and precipitation procedures. Quality and quantity of the DNA were determined spectrophotometrically $\left[\mathrm{A}_{230 / 200}: \sim 0.4, \mathrm{~A}_{260 / 280^{\circ}} \sim 1.8\right]$ and ultimately, its concentration was adjusted to $1 \mathrm{mg} / \mathrm{ml}$.

\section{HPLC-ECD for determining 8-oxo-dG in PBL}

HPLC-ECD of lymphocytic 8-oxo-dG was done as described earlier (42). Briefly, DNA was digested into deoxyribonucleosides after treatment with nuclease P1 $0.02 \mathrm{U} / \mu \mathrm{l}]$ and alkaline phosphatase $[0.01 \mathrm{U} / \mu \mathrm{l}]$. The digest was then injected into a Spectroflow 480 isocratic pump (Gynkotek, München, Germany) coupled with a Spectroflow 783 injector (Kratos, Ramsey, $\mathrm{NJ})$ and connected to a Supelcosil ${ }^{\mathrm{TM}}$ LC- $18 \mathrm{~S}$ column $(250 \times 4.6 \mathrm{~mm})$ and an electrochemical detector CU-04-AZ (Antec, Leiden, the Netherlands). The mobile phase consisted of 10\% aqueous methanol containing $25 \mathrm{mM}$ sodium acetate, $12.5 \mathrm{mM}$ citric acid, $30 \mathrm{mM}$ sodium hydroxide and $10 \mathrm{mM}$ acetic acid. Elution was performed at a flow rate of $1.0 \mathrm{ml} / \mathrm{min}$ with a 
lower detection limit of $40 \mathrm{fmol}$ absolute for 8 -oxo-dG, or 1.5 residues $/ 10^{6} 2$ 'deoxyguanosine $(\mathrm{dG})$. $\mathrm{dG}$ was simultaneously monitored at $260 \mathrm{~nm}$. Results were expressed as the ratios of determined $8-\mathrm{OH}-\mathrm{dG}$ to $\mathrm{dG}$.

\section{Endonuclease III Comet Analysis}

The endonuclease III-modified comet assay was performed according to the method of Collins et al. (43). Briefly, PBL $\left[1 \times 10^{5}\right]$ were embedded in a layer of low melting point agarose on a microscope slide and subsequently, lysed with $2.5 \mathrm{M} \mathrm{NaCl}, 0.1 \mathrm{M} \mathrm{Na}_{2} \mathrm{EDTA}, 10 \mathrm{mM}$ Tris$\mathrm{HCl}$ and $1 \%$ Triton $\mathrm{X}-100, \mathrm{pH} 10.0$ for $1 \mathrm{~h}$ at $4^{\circ} \mathrm{C}$. The slides were rinsed with endonuclease buffer [ $40 \mathrm{mM}$ Hepes, $0.1 \mathrm{M} \mathrm{KCl}, 0.5 \mathrm{mM}$ EDTA and bovine serum albumin $\{0.2 \mathrm{mg} / \mathrm{ml}\}$, $\mathrm{pH}$ 8.0] and then, treated with either endonuclease III [1:500] or the endonuclease buffer for 30 min at $37^{\circ} \mathrm{C}$ [a non-treated control slide was also included]. After alkaline electrophoresis, neutralization and ethidiumbromide staining, the slides were evaluated under a fluorescence microscope. Quantification was done by means of an Image Processing and Analysis System (Quantimet 500, Leica, Cambridge, UK) measuring the percentage of DNA in the tail, tail length and tail moment [\% DNA in the tail multiplied by tail length] in 50 cells per slides. To correct for background, all measured parameters in the endonuclease-buffer treated slides were subtracted from their respectives in endonuclease III-treated slides. Results were expressed in arbitrary units established by the Image Analyzer.

\section{ELISA for determining 8-OH-dG in urine}

Urinary 8-OH-dG was quantified by means of an ELISA kit (Japan Institute for the control of aging, Shizuoka Pref., Japan) the validity and comparability of which to HPLC-ECD had already been verified (44-47). Briefly, samples and standards of 8-OH-dG [0.5, 2, 8, 20, 80 and $200 \mathrm{ng} / \mathrm{ml}$ ] were placed in microtiter plates [ $8 \times 12$ wells, split type] pre-coated with 8$\mathrm{OH}-\mathrm{dG}$. A monoclonal primary antibody recognizing $8-\mathrm{OH}-\mathrm{dG}$ was then added and incubation was done for $1 \mathrm{~h}$ at $37^{\circ} \mathrm{C}$. The plates were rinsed with phosphate buffered saline (PBS), pH 7.4 and subsequently, incubated with an enzyme-labeled secondary antibody for 1 $h$ at $37^{\circ} \mathrm{C}$. After rinsing with PBS, the chromatic substrate, 3,3',5,5'-tetramethylbenzidine, was added and incubation was carried out for $15 \mathrm{~min}$ at $37^{\circ} \mathrm{C}$ at the dark. The reaction was terminated by adding $1 \mathrm{~N}$ phosphoric acid and after a lag time of approximately $3 \mathrm{~min}$, the plates were read by a Microplate Reader measuring the absorbance at $450 \mathrm{~nm}$. A standard curve was established by plotting the measured absorbance versus log concentration of the 8$\mathrm{OH}-\mathrm{dG}$ standards. Results were expressed in ng/body mass index (BMI). 


\section{UDS for determining overall DNA repair}

UDS analysis of the samples was performed as described earlier (48). Briefly, unstimulated blood leukocytes were cultured in the presence of [methyl- $\left.{ }^{3} \mathrm{H}\right]$ thymidine $[10 \mu \mathrm{Ci} / \mathrm{ml}]$ (Amersham, Buckinghamshire, UK) for $24 \mathrm{~h}$ in a humidified incubator at $37^{\circ} \mathrm{C}$ under $5 \% \mathrm{CO}_{2}$. The cells were hypotonized with $75 \mathrm{mM} \mathrm{KCl}$ for $10 \mathrm{~min}$, fixed with methanol:acetic acid [3:1] and subsequently, dropped onto microscope slides. The slides were dipped into Illford $\mathrm{K} 2$ Scientific Emulsion (Illford, Mobberley Knutsford Cheshire, UK), drained on an absorbent paper and then, kept for a period of $10-14$ days at $4^{\circ} \mathrm{C}$ in the dark. Afterwards, the slides were developed in a photo emulsion at $21^{\circ} \mathrm{C}$, fixed [fixative: sodiumthiosulfate $\{200 \mathrm{~g}\}+$ potassium metabisulfite $\{20 \mathrm{~g}\}+$ potassium chromosulfate $\{10 \mathrm{~g}\} / \mathrm{L}]$ and finally, counterstained with hematoxin. The slides were evaluated under a Zeiss Axioskop microscope (Zeiss, Oberkochen, Germany) equipped with a CHOU high performance CCD camera (Leica, Cambridge, UK) and coupled to an Artek Counter ${ }^{\mathrm{TM}} 880$ (New Brunswick Scientific, New York, NY). Quantification was based on the number of grains scored in 250 nuclei per slide [corrected for extra nucleus grains as background].

\section{TEAC for determining scavenging capacity of plasma antioxidants}

The TEAC assay was performed as described earlier (49). Briefly, after generation of the long-lived radical anion of ABTS in the presence of a thermolabile azo compound, 2,2'azobis-2-amidinopropane (ABAP), plasma was added and subsequently, absorbance was monitored at $734 \mathrm{~nm}$ over a period of $6 \mathrm{~min}$. The decrease in the absorbance after addition of the plasma was plotted on a calibration curve established by application of known concentrations of Trolox, an analogue of vitamin E, as standard. Results were expressed as $\mu \mathrm{M}$ Trolox equivalents.

\section{PCR for genotyping GSTM1 and hOGGI}

Genotype determination for GSTMI and hOGGI was done according to the published PCRbased procedures $(50,51)$. In the case of $h O G G 1$, as (Ser/Ser) variant has been shown to encode for the enzyme with the highest effectivity (36), we used this genotype as the reference.

\section{Statistical analysis}

Results were expressed as mean \pm standard error throughout. All variables in the smoking group were compared with their respectives in the non-smoking group using the MannWhitney $U$-test. The relationships between different variables were evaluated by the Spearman 
rank correlation analysis. To assess the impact of various independent variables on a dependant one, a multiple linear regression analysis was performed using the logarithmically transformed dependant variable and up to three independent variables. Statistical significance was considered at $\mathrm{P}<0.05$.

\section{RESULTS}

Table 2 summarizes the quantified biomarkers of this study. Lymphocytic 8-oxo-dG levels in smokers were significantly lower than those in non-smokers $(38.6 \pm 5.2$ versus $50.9 \pm$ $4.6 / 10^{6} \mathrm{dG}, \mathrm{P}=0.05$ ) [Fig. 1]. In smokers and non-smokers, respectively, the levels of lymphocytic 8-oxo-dG varied in the ranges of $17-75 / 10^{6} \mathrm{dG}$ and $28-83 / 10^{6} \mathrm{dG}$. In smokers there was no significant relationship between lymphocytic 8-oxo-dG levels and questionnaire-derived smoking indices (cig/day and pack years).

Table 2. Summary data of the quantified biomarkers in smokers and non-smokers

\begin{tabular}{|c|c|c|c|}
\hline & & $\begin{array}{c}\text { Smokers ( } \mathrm{n=2I}) \\
\text { Mean } \pm \text { SE [Range] }\end{array}$ & $\begin{array}{c}\text { Non-smokers ( } n=21) \\
\text { Mean } \pm \text { SE [Range] }\end{array}$ \\
\hline \multicolumn{2}{|c|}{ Lymphocytic 8-OH.dG $\left[/ 10^{\prime \prime} d G\right]$} & $38.6 \pm 5.2[17-75]^{1}$ & $50.9 \pm 4.6[28-8.3]$ \\
\hline \multirow{3}{*}{ Simple comet } & \%DNA in tail & $16 \pm 0.4[1.3-18]$ & $16 \pm 0.9[14-21]$ \\
\hline & Tail length & $173 \pm 19[80-317]$ & $174 \pm 17[88-303]$ \\
\hline & Tail moment & $2710 \pm 294[1379-4711]$ & $2938 \pm 406[13.32-396.3]$ \\
\hline \multirow{3}{*}{ Endonuclease III comet } & \%DNA in tail & $13 \pm 3[2-24]$ & $14 \pm 2[1-29]$ \\
\hline & Tail length & $69 \pm 13[2-154]$ & $96=10[48-154]$ \\
\hline & Tail moment & $6416 \pm 1220[826-11102]$ & $7545 \pm 12.34[2101-14749]$ \\
\hline \multicolumn{2}{|c|}{ Urinary 8-OH-dG [ng/body mass index] } & $197 \pm 31[78-449]$ & $240 \pm 33[60-472]$ \\
\hline \multicolumn{2}{|c|}{ Unscheduled DNA synthesis } & $2.9 \pm 0.3[1.6-5.0]$ & $3.3 \pm 0.3[1.3-5.5]$ \\
\hline \multicolumn{2}{|c|}{ Plasma antioxidative capacity [ $\mu \mathrm{M}$ Trolox equivalent] } & $440 \pm 16[3.58-545]$ & $400 \pm 15[307-488]$ \\
\hline \multicolumn{2}{|l|}{$\operatorname{GSTM} /[(-/-) .(+)]^{2}$} & 13.8 & $15,8^{3}$ \\
\hline \multicolumn{2}{|c|}{ hOGGI [(Ser/Ser), (Ser/Cys), (Cys/Cys)] $]^{2}$} & 12.9 .0 & $15,7,1^{3}$ \\
\hline
\end{tabular}

'statistically significant as compared to non-smokers, $\mathrm{P}=0.05$.

${ }^{2}$ Absolute number of the individuals possessing the genotype is indicated.

$x_{n}=23$ 
In both smokers and non-smokers the levels of lymphocytic 8-oxo-dG were negatively associated with age ( $r=0.5, P=0.07$ and $r=0.5, P=0.02$, respectively). Also, lymphocytic 8oxo-dG levels in female smokers and non-smokers were higher than those in male respectives (48.4 \pm 6.9 versus $24.6 \pm 4.2 / 10^{6} \mathrm{dG}, \mathrm{P}=0.02$ and $52.4 \pm 5.1$ versus $45.4 \pm 10.5 / 10^{6} \mathrm{dG}, \mathrm{P}=$ 0.5 , respectively). Multiple regression analysis with age, gender and smoking status as independent variables showed that the levels of lymphocytic 8-oxo-dG can be best predicted by age ( $r=0.6, P=0.003$ ). After adjustment for age, smokers still had significantly lower levels of lymphocytic 8-oxo-dG than non-smokers $(P=0.03)$ [Fig. 1].

In the simple comet assay there was no difference in any of the measured parameters between smokers and non-smokers (\% DNA in tail, $16 \pm 0.4$ versus $16 \pm 0.9$; tail length, 173 \pm 19 versus $174 \pm 17$; tail moment, $2710 \pm 294$ versus $2938 \pm 406$ ). In the endonuclease IIImodified comet assay the differences were more pronounced, yet, non-significant (\% DNA in tail, $13 \pm 3$ versus $14 \pm 2$; tail length, $69 \pm 13$ versus $96 \pm 10$; tail moment, $6416 \pm 1220$ versus $7545 \pm 1234$ ). Neither simple nor endonuclease III-modified comet data did correlate with the data on smoking status or gender or age. Overall, endonuclease III-modified comet parameters tended to be associated with lymphocytic 8-oxo-dG levels [adjusted for age] ( $\mathrm{r}=$ $0.3, \mathrm{P}=0.2)$.

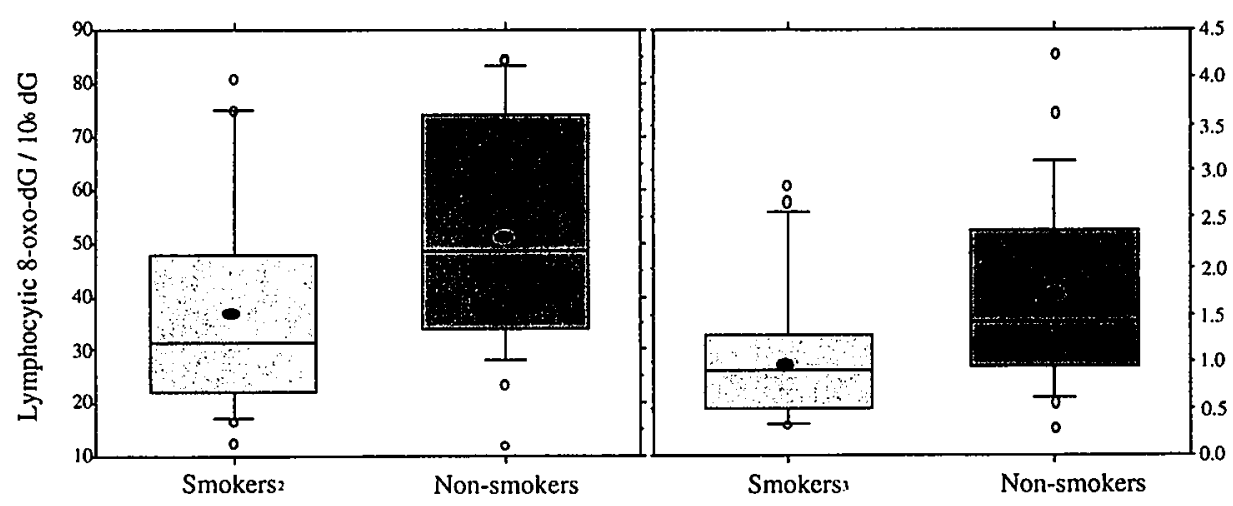

Fig.1. Distribution of the levels of 8-oxo-dG in peripheral blood lymphocytes of smokers and non-smokers. The lower and upper edges of the boxes, the $25^{\text {th }}$ and the $75^{\text {th }}$ percentiles, respectively. o and - within the boxes, the means and the medians, respectively. Lower and upper bars, the $10^{\text {th }}$ and the $90^{\text {th }}$ percentiles, respectively. 0 , Individual values $<10^{\text {th }}$ or $>90^{\text {th }}$ percentiles.

'Adjusted for age and expressed in arbitrary units.

${ }^{2}$ Statistically significant as compared to non-smokers, $\mathrm{P}=0.05$.

, 3 tatistically significant as comparcd to non-smokers, $\mathrm{P}=0.03$. 
Urinary excretion levels of 8-OH-dG did not differ between smokers and non-smokers (197 \pm 31 versus $240 \pm 33 \mathrm{ng} / \mathrm{BMI}, \mathrm{P}=0.3$ ). The levels of urinary $8-\mathrm{OH}-\mathrm{dG}$ ranged from 78 to $449 \mathrm{ng} / \mathrm{BMI}$ in smokers and from 60 to $472 \mathrm{ng} / \mathrm{BMI}$ in non-smokers. Urinary excretion levels of 8-OH-dG in smokers were non-significantly related to smoking index (cig/day, $\mathrm{r}=$ $0.4, \mathrm{P}=0.07$ ). Also, there was an inverse correlation between smokers' urinary 8-OH-dG and lymphocytic 8-oxo-dG levels ( $\mathrm{r}=0.4, \mathrm{P}=0.09$, adjusted for age) [Fig. 2]. No association was found between urinary excretion of $8-\mathrm{OH}-\mathrm{dG}$ and comet parameters or gender or age.

There was no significant difference in UDS between smokers and non-smokers $(2.9 \pm$ 0.3 versus $3.3 \pm 0.3, P=0.4$ ). In smokers and non-smokers UDS levels ranged from 1.6 to 5.0 and from 1.3 to 5.5 , respectively. Smokers' UDS did not relate to their smoking indices. Nor did UDS correlate with urinary 8-OH-dG or lymphocytic 8-oxo-dG [adjusted for age] or comet parameters or gender or age.

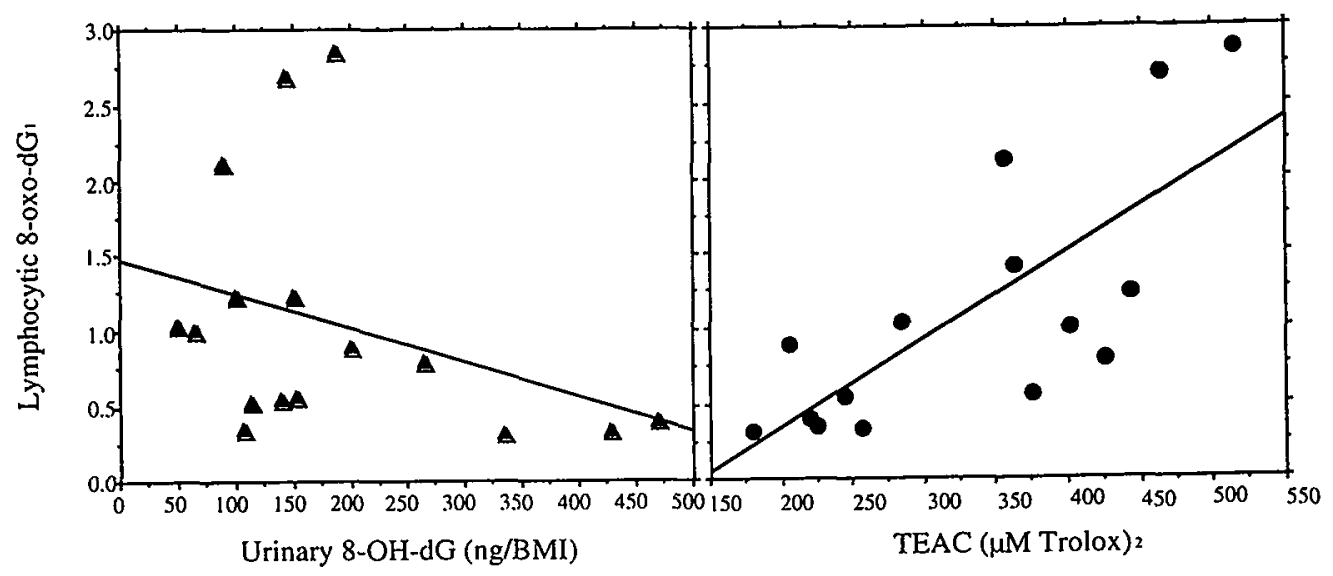

Fig.2. Relationships between lymphocytic 8-oxo-dG and urinary 8-OH-dG $(r=0.4, P=0.009)$ and plasma antioxidative scavenging capacity $(r=0.7, P=0.006)$ in smokers.

'Adjusted for age and expressed in arbitrary units.

${ }^{2}$ Trolox equivalent antioxidant capacity. 
Plasma antioxidants scavenging capacity in smokers was non-significantly higher than that in non-smokers $(440 \pm 16$ versus $400 \pm 15 \mu \mathrm{M}$ Trolox equivalent, $\mathrm{P}=0.09)$. The scavenging capacities of plasma antioxidants were in the ranges of $358-545 \mu \mathrm{M}$ Trolox equivalent in smokers, and $307-488 \mu \mathrm{M}$ Trolox equivalent in non-smokers. In smokers plasma antioxidants scavenging capacity was not related to smoking indices. Plasma antioxidants scavenging capacities in male smokers and non-smokers were higher than those in female respectives ( $474 \pm 27$ versus $416 \pm 15 \mu \mathrm{M}$ Trolox equivalent, $\mathrm{P}=0.1$ and $479 \pm 18$ versus $373 \pm 14 \mu \mathrm{M}$ Trolox equivalent, $\mathrm{P}=0.002$, respectively). Overall, there was an inverse relationship between plasma antioxidative capacity and age $(r=0.5, P=0.003$, adjusted for gender). Multiple regression analysis with gender and age and smoking status as independent variables showed that plasma antioxidants scavenging capacity can only be significantly predicted by gender $(r=0.6, P=0.0007)$. Adjusting the data for gender, there was no difference in plasma antioxidative capacity between smokers and non-smokers $(P=0.9)$. Overall, there was a significant relationship between plasma antioxidative capacity and lymphocytic 8-oxo-dG levels $(r=0.4, P=0.01$, adjusted for gender and age); multiple regression analysis revealed that this relationship had major impact on the correlation between urinary 8-OH-dG and lymphocytic 8-oxo-dG in smokers [Fig. 2]. No association was found between plasma antioxidants scavenging capacity and UDS or urinary $8-\mathrm{OH}-\mathrm{dG}$ or comet parameters. In smokers multiple regression analysis with plasma antioxidative capacity, urinary 8-OH-dG and UDS as independent variables showed that the levels of lymphocytic 8oxo-dG can be best predicted by plasma antioxidants scavenging capacity $(r=0.9, P=0.007)$.

Prevalence of GSTMI null genotype, GSTMI(-/), in smokers, in non-smokers and in overall smokers and non-smokers were $65 \%, 62 \%$, and $54 \%$, respectively. Overall, GSTMI $(-/)$ individuals did not differ from $G S T M I(+)$ ones regarding age, gender and smoking status. GSTMI genotyping data were not associated with the data on plasma antioxidants scavenging capacity [adjusted for gender] or UDS or comet or urinary 8-OH-dG or lymphocytic 8-oxo-dG [adjusted for age] [Fig. 3].

Prevalence of hOGGl(Ser/Ser), (Ser/Cys) and (Cys/Cys) genotypes were 57.1, 42.9 and $0.0 \%$, respectively, in smokers, $65.2,30.4$ and $4.4 \%$, respectively, in non-smokers and 61.4 , 36.4 and $2.2 \%$, respectively, in overall smokers and non-smokers. There was no significant difference between individuals with $h O G G l(\mathrm{Ser} / \mathrm{Ser})$ genotype and those with (Ser/Cys) or (Cys/Cys) genotypes in terms of age, gender and smoking status. Overall, there was no association between $h O G G l$ genotyping data and the data on plasma antioxidants scavenging capacity [adjusted for gender and age] or UDS or comet, or urinary 8-OH-dG or lymphocytic 8-oxo-dG [adjusted for cig/day and age, respectively] [Fig. 3]. Possession of $h O G G 1(\operatorname{Ser} / \mathrm{Ser})$ and GSTMI $(+)$ genotypes did not affect additively or multiplicatively any of the above-mentioned parameters. 

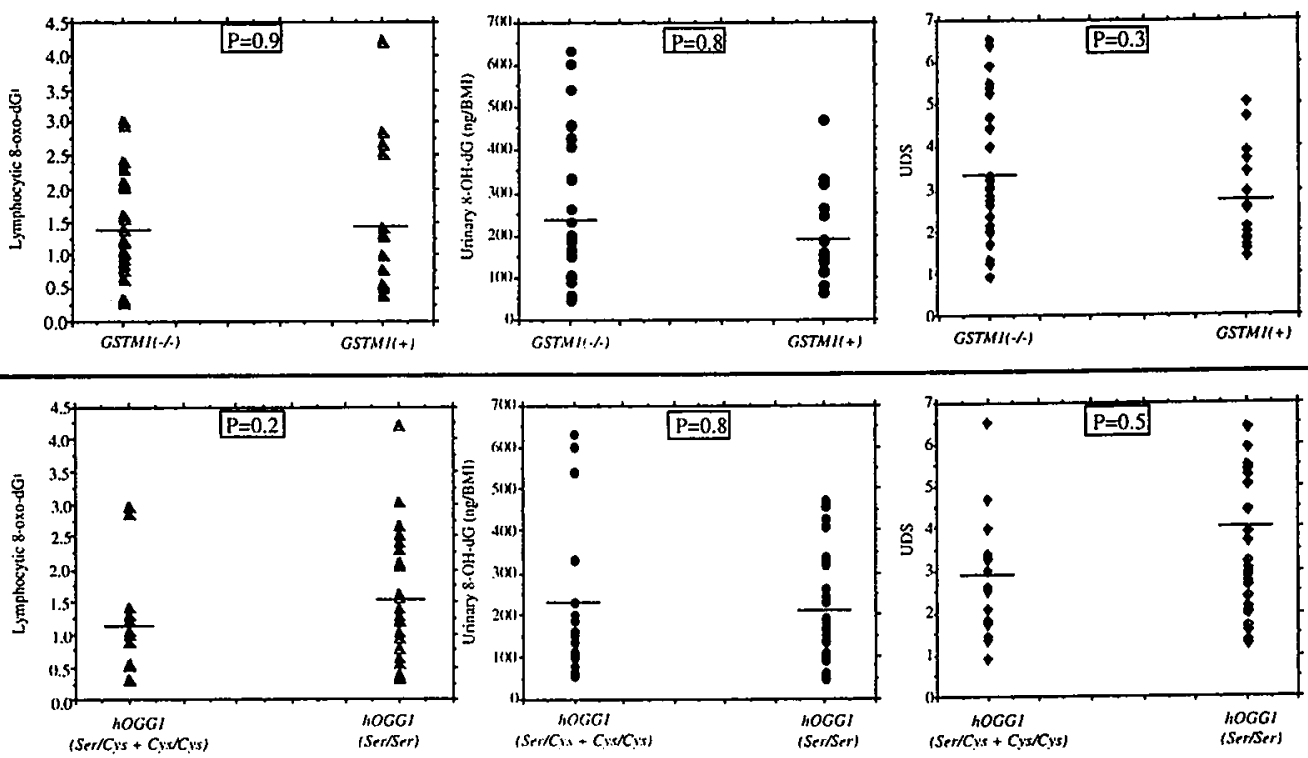

Fig. 3. Association between GSTMI and hOGGl genotypes and lymphocytic 8-oxo-dG and urinary 8-OH-dG and UDS. - within the scattered values, the means.

'Adjusted for age and expressed in arbitrary units.

\section{DISCUSSION}

In this study, we observed lower levels of the well-established marker of oxidative DNA damage, 8-oxo-dG, in lymphocytes of smokers as compared to non-smokers. This is in agreement with our previous observation (41) as well as with one recent report by others (52). However, two other studies in leukocytes and lung tissues have shown the opposite $(53,54)$. As we demonstrated, lymphocytic 8-oxo-dG levels are considerably dependent upon age and smoking status, whereas the contradicting lung study provided no indication of age adjustment in its analysis (54). In addition, the exposure variable may have also contributed to this discrepancy because the lung in that study as opposed to the PBL in the present study, has higher and more direct exposure to the smoking materials. In the other contradictory report (53), the investigated population consisted of heavy smokers with intense smoking behaviors [high lifetime consumption of cigarette with an average of $34 \mathrm{cig} / \mathrm{day}$ ]. Our study population was, however, made up of moderate smokers. Interestingly, the characteristics of the study populations in both confirming reports are comparable to those in ours $(41,52)$. Furthermore, 
we found a tendency towards lower levels of oxidized pyrimidine bases in the comet analysis of lymphocytes of smokers versus non-smokers, which is in contrast to two other reports $(43,55)$. This latter discrepancy may also be ascribed to the apparent differences in the characteristics of the examined populations. At the same time, the less pronounced difference in comet-quantified parameters versus lymphocytic 8-oxo-dG between smokers and nonsmokers questions the sensitivity of the comet assay for detecting smoke-related oxidative lesions. Taken together, it seems that a modulation occurs in smoking-induced oxidative DNA damages as a result of up-regulation of the primary defense antioxidative system and/or complementary DNA repair system.

Regarding the DNA repair pathway, we observed no significant difference in urinary excretion levels of $8-\mathrm{OH}-\mathrm{dG}$ between smokers and non-smokers. Indeed, previous investigations on the urinary excretion of this repair product in smokers have not been conclusive, either (56-59). Also, we did not find any significant difference in DNA repair activity expressed as UDS, between smokers and non-smokers. It should be underlined that our UDS analysis was performed in blood leukocytes comprising several cell types with varying DNA repair activity rates $(60,61)$. However, we measured the extent of oxidative DNA damage only in lymphocytes, which comprise about $35 \%$ of the total white blood cells (62). Besides, the quantified UDS is a collective index for both base excision repair (BER) and nucleotide excision repair (NER) activities (48), whereas most oxidative DNA lesions are repaired merely via $B E R$ pathway (24). In our study, polymorphism of the specified BER gene, hOGGl, could not impact upon the corresponding markers. It should be noted that although in in vitro systems multi-variant products of hOGGI have been shown to differently repair 8-oxo-Gua (34), there has not been any association between the polymorphic variants of this gene and the level of 8-oxo-dG in in vivo studies. Nor have hOGGl-encoded enzymes been associated with susceptibility to lung or kidney or gastric cancer $(34,35,51,63,64)$. It appears that although $h O G G I$ constitutes a major pathway of repair for 8-oxo-Gua, other genes such as $h M Y H$ and $h M T H$ may have considerable impacts on the repair of this lesion $(32,65)$.

Thus far, there have been controversial reports on the effects of oxidative stress on plasma antioxidants scavenging capacity (16,66-70). For instance, plasma antioxidants trapping activity has been shown to be inversely/positively related to strenuous exercise and physical activities, smoking, lung cancer and neonatal prematurity, all imposing a massive influx of ROS. In the present study, we observed an up-regulation of this primary defense system in males, which may relate to the fact that males are under greater oxidative burden due to their higher metabolic rate (71) as well as in smokers as compared to females and nonsmokers, respectively. We then found that such trend was mostly gender-related because adjustment of data for gender bridged the gap between smokers and non-smokers. This together with the positive linearity between lymphocytic 8-oxo-dG and plasma antioxidants scavenging capacity implies that the antioxidative defense system is only marginally affected by smoking-induced oxidative stress. In other words, the down-regulation of oxidative DNA damage in smokers is likely to be due to modulatory mechanisms other than plasma antioxidants scavenging capacity. 
Regarding the ROS detoxifying system, we did not find an influence of GSTMI on any of the quantified biomarkers. Conceivably, GSTMI is only one of the genes whose product is involved in the detoxification of ROS. It is possible that other genes encoding for the influential detoxifying enzymes e.g., superoxide dismutase, catalase and glutathion peroxidase in combination with GSTMI or separately, play a more crucial role in response to oxidative stress $(15,17)$.

In summary, we have demonstrated that smoking-induced oxidative stress may impact upon certain pathways involved in DNA damage and antioxidative defense mechanisms. However, given the marginal effects of smoking and contributory effects of host factors e.g., gender and age, on these pathways, it is unlikely to observe an explicit adaptive response towards smoking cspecially in light and moderate smokers. To better understand the effects of smoking-induced oxidative stress in humans, future large-scale research is needed to elucidate the role of relevant polymorphic genes specifically, those encoding for DNA repair enzymatic networks.

\section{ACKNOWLEDGEMENT}

We would like to thank Prof. Ch.P. Wild, Dr. L.J. Hardie and Ms J.A. Briggs of Molecular Epidemiology Unit, University of Leeds, for performing the $h O G G l$ analysis. 


\section{REFERENCE}

1. DiGuiseppi, J. and Fridovich I. (1984) The toxicology of molecular oxygen. Crit Rev Toxicol, 12, 315-342.

2. Ames, B.N. (1989) Endogenous DNA damage as related to cancer and aging. Mutat Res, 214, 41-46.

3. Cadenas, E. (1989) Biochemistry of oxygen toxicity. Annu Rev Biochem, 58, 79-110.

4. Joenje, H. (1989) Genetic toxicology of oxygen. Mutat Res, 219, 193-208.

5. Esterbauer, H., Eckl P. and Ortner A. (1990) Possible mutagens derived from lipids and lipid precursors. Mutat Res, 238, 223-233.

6. Fridovich, I. (1978) The biology of oxygen radicals. Science, 201, 875-880.

7. Drapier, J.C. and Hibbs J.B.Jr. (1988) Differentiation of murine macrophages to express nonspecific cytotoxicity for tumor cclls results in L-arginine-dependent inhibition of mitochondrial iron-sulfur cnzymes in the macrophage effector cells. $J$ Immunol, 140, 2829-2838.

8. Hibbs, J.B.Jr., Taintor R.R., Vavrin Z. and Rachlin E.M. (1988) Nitric oxide: a cytotoxic activated macrophage effector molecule. Biochem Biophys Res Commun, 157, 87-94.

9. Ames, B.N., Shigenaga M.K. and Hagen T.M. (1993) Oxidants, antioxidants, and the degenerative diseases of aging. Proc Natl Acad Sci U S A. 90, 7915-7922.

10. Ignarro, L.J. (1990) Haem-dependent activation of guanylate cyclase and cyclic GMP formation by endogenous nitric oxide: a unique transduction mechanism for transcellular signaling. Pharmacol Toxicol, 67, 1-7.

11. Bredt, D.S. and Snyder S.H. (1992) Nitric oxide, a novel neuronal messenger. Neuron, 8, 3-11.

12. Koppenol, W.H., Moreno J.J., Pryor W.A., Ischiropoulos H. and Beckman J.S. (1992) Peroxynitritc, a cloaked oxidant formed by nitric oxide and superoxide. Chem Res Toxicol, 5, 834-842.

13. Halliwell, B. and Aruoma O.I. (1991) DNA damage by oxygen-derived species. Its mechanism and measurement in mammalian systems. FEBS Lett, 281, 9-19.

14. Frei, B., England L. and Ames B.N. (1989) Ascorbate is an outstanding antioxidant in human blood plasma. Proc Natl Acad Sci U S A, 86, 6377-6381.

15. Halliwell, B. and Gutteridge J.M. (1990) The antioxidants of human extracellular fluids. Arch Biochem Biophys, 280, 1-8.

16. Motchnik, P.A., Frei B. and Ames B.N. (1994) Measurement of antioxidants in human blood plasma. Methods Enzymol, 234, 269-279.

17. Hayes, J.D. and Pulford D.J. (1995) The glutathione $S$-transferase supergene family: regulation of GST and the contribution of the isoenzymes to cancer chemoprotection and drug resistance. Crit Rev Biochem Mol Biol, 30, 445-600.

18. Strange, R.C., Matharoo B., Faulder G.C., Jones P., Cotton W., Elder J.B. and Deakin M. (1991) The human glutathione $S$-transferases: a case-control study of the incidence of the GST1 0 phenotype in patients with adenocarcinoma. Carcinogenesis, 12, 25-28.

19. Zhong, S., Howie A.F., Ketterer B., Taylor J., Hayes J.D., Becketl G.J., Wathen C.G., Wolf C.R. and Spurr N.K. (1991) Glutathione $S$-transferase mu locus: use of genotyping and phenotyping assays to assess association with lung cancer susceptibility. Carcinogenesis, 12, 1533-1537.

20. Anttila, S., Hirvonen A., Husgafvel-Pursiainen K., Karjalainen A., Nurminen T. and Vainio H. (1994) Combined effect of CYPIAI inducibility and GSTMI polymorphism on histological type of lung cancer. Carcinogenesis, 15, 1133-1135. 
21. Brockmoller, J., Kerb R., Drakoulis N., Staffeldt B. and Roots I. (1994) Glutathione S-transferase M1 and its variants $A$ and $B$ as host factors of bladder cancer susceptibility: a case-control study. Cancer Res, 54, 4103-4111.

22. Lin. H.J., Probst-Hensch N.M., Ingles S.A., Han C.Y., Lin B.K., Lee D.B., Frankl H.D., Lee E.R., Longnecker M.P. and Haile R.W. (1995) Glutathione transferase (GSTMI) null genotype, smoking, and prevalence of colorectal adenomas. Cancer Res, 55, 1224-1226.

23. Breimer, L.H. (1991) Repair of DNA damage induced by reactive oxygen species. Free Radic Res Commun, 14, 159-171.

24. Demple, B. and Harrison L. (1994) Repair of oxidative damage to DNA: enzymology and biology. Annu Rev Biochem, 63, 915-948.

25. Kuchino, Y., Mori F., Kasai H., Inoue H., Iwai S., Miura K., Ohtsuka E. and Nishimura S. (1987) Misreading of DNA templates containing 8-hydroxydeoxyguanosine at the modified base and at adjacent residues. Nature, 327, 77-79.

26. Shigenaga, M.K., Gimeno C.J. and Ames B.N. (1989) Urinary 8-hydroxy-2'-deoxyguanosine as a biological marker of in vivo oxidative DNA damage. Proc Natl Acad Sci U S A, 86, 9697-9701.

27. Floyd, R.A. (1990) The role of 8-hydroxyguanine in carcinogenesis. Carcinogenesis, 11, 1447-1450.

28. Wood, M.L., Dizdaroglu M., Gajewski E. and Essigmann J.M. (1990) Mechanistic studies of ionizing radiation and oxidative mutagencsis: genetic effects of a single 8-hydroxyguanine (7-hydro-8oxoguanine) residuc inserted at a unique sile in a viral genome. Biochemistry, 29, 7024-7032.

29. Shibutani, S., Takcshita M. and Grollman A.P. (1991) Insertion of specific bases during DNA synthesis past the oxidation-damaged base 8-oxodG. Nature, 349, 431-434.

30. Cheng, K.C., Cahill D.S., Kasai H., Nishimura S. and Locb L.A. (1992) 8-Hydroxyguanine, an abundant form of oxidative DNA damage, causes $G \rightarrow T$ and $A \rightarrow C$ substitutions. $J$ Biol Chem, 267, 166-172.

31. Aburatani, H., Hippo Y., Ishida T., Takashima R., Matsuba C., Kodama T., Takao M., Yasui A., Yamamoto K. and Asano M. (1997) Cloning and characterization of mammalian 8-hydroxyguaninespecific DNA glycosylase/apurinic, apyrimidinic lyase, a functional mutM homologue. Cancer Res, 57, 2151-2156.

32. Arai, K., Morishita K., Shinmura K., Kohno T., Kim S.R., Nohmi T., Taniwaki M., Ohwada S. and Yokota J. (1997) Cloning of a human homolog of the yeast OGGl gene that is involved in the repair of oxidative DNA damage. Oncogene, 14, 2857-2861.

33. Radicella, J.P., Dherin C., Desmaze C., Fox M.S. and Boiteux S. (1997) Cloning and characterization of hOGGI, a human homolog of the OGG/ gene of Saccharomyces cerevisiae. Proc Natl Acad Sci US A, 94, 8010-8015.

34. Kohno, T., Shinmura K., Tosaka M., Tani M., Kim S.R., Sugimura H., Nohmi T., Kasai H. and Yokota J. (1998) Genetic polymorphisms and alternative splicing of the hOGGl gene, that is involved in the repair of 8-hydroxyguanine in damaged DNA. Oncogene, 16, 3219-3225.

35. Chevillard, S., Radicella J.P., Levalois C., Lebeau J., Poupon M.F., Oudard S., Dutrillaux B. and Boiteux S. (1998) Mutations in $O G G I$, a gene involved in the repair of oxidative DNA damage, are found in human lung and kidney tumours. Oncogene, 16, 3083-3086.

36. Shinmura, K., Kasai H., Sasaki A., Sugimura H. and Yokota J. (1997) 8-hydroxyguanine (7,8-dihydro8-oxoguanine) DNA glycosylase and AP lyase activitics of hOGGl protein and their substrate specificity. Mutat Res, 385, 75-82. 
37. Nakayama, T., Kodama M. and Nagata C. (1984) Generation of hydrogen peroxide and superoxide anion radical from cigarette smoke. Gann, 75, 95-98.

38. Cosgrove, J.P., Borish E.T., Church D.F. and Pryor W.A. (1985) The metal-mediated formation of hydroxyl radical by aqueous extracts of cigarette tar. Biochem Biophys Res Conmun, 132, 390-396.

39. Jackson. J.H., Gajcwski E., Schraufstatter I.U., Hyslop P.A., Fuciarelli A.F., Cochrane C.G. and Dizdaroglu M. (1989) Damage to the bases in DNA induced by stimulated human neutrophils. $J$ Clin Invest, 84, 1644-1649.

40. Bøyum, A. (1976) Isolation of lymphocytes, granulocytes and macrophages. Scand J Immunol, 5, 915.

41. Zwingmann, I.H., Welle I.J., van Herwijnen M., Engelen J.J., Schilderman P.A., Smid T. and Kleinjans J.C. (1998) Oxidative DNA damage and cytogenetic effects in flight engineers exposed to cosmic radiation. Environ Mol Mutagen, 32, 121-129.

42. Schilderman, P.A., van Maanen J.M., ten Vaarwerk F.J., Lafleur M.V., Westmijze E.J., ten Hoor F. and Kleinjans J.C. (1993) The role of prostaglandin $H$ synthasc-mediated metaholism in the induction of oxidative DNA damage by BHA metabolites. Carcinogenesis, 14, 1297-302.

43. Collins, A.R., Duthic S.J. and Dobson V.L. (1993) Direct enzymatic detection of endogenous oxidative base damage in human lymphocyte DNA. Carcinogenesis. 14, 1733-1735.

44. Osawa, T., Yoshida A.. Kawakishi S., Yamashita K. and Ochi H. (1995) Protective role of diclary antioxidants in oxidative stress. In Cutler, L., Packer, L., Bertram, J. and Mori, A. (cds), Oxidative stress and aging. Basel, Birkhauser, pp. 367-377.

45. Erhola. M., Toyokuni S., Okada K., Tanaka T., Hiai H., Ochi H., Uchida K., Osawa T., Nieminen M.M., Alho H. and Kellokumpu-Lehtinen P. (1997) Biomarker evidence of DNA oxidation in lung cancer patients: association of urinary 8-hydroxy-2'-deoxyguanosine excretion with radiotherapy, chemotherapy, and response to treatment. FEBS Lett, 409, 287-291.

46. Toyokuni, S., Tanaka T., Hattori Y., Nishiyama Y., Yoshida A., Uchida K.. Hiai H., Ochi H. and Osawa T. (1997) Quantitative immunohistochemical determination of 8-hydroxy-2'- deoxyguanosine by a monoclonal antibody N45.1: its application to ferric nitrilotriacetate-induced renal carcinogenesis model. Lab Invest, 76, 365-374.

47. Tsuboi, H., Kouda K., Takeuchi H., Takigawa M., Masamoto Y., Takeuchi M. and Ochi H. (1998) 8hydroxydcoxyguanosine in urine as an index of oxidative damage to DNA in the cvaluation of atopic dermatitis. Br J Dermatol, 138, 1033-1035.

48. Stierum, R.H., van Herwijnen M.H., Hageman G.J. and Kleinjans J.C. (1994) Increased poly(ADPribose) polymerase activity during repair of ( \pm )-anti-benzo[a]pyrene diolepoxide-induced DNA damage in human peripheral blood lymphocytes in vitro. Carcinogenesis, 15, 745-751.

49. Van den Berg, R., Haenen, GRMM, Van den Berg, H and Bast, A (1999) Applicability of an improved Trolox equivalent antioxidant capacity (TEAC) assay for evaluation of antioxidant capacity measurements of mixtures. Food Chemistry, 66, 511-517.

50. Cheng, T.J., Christiani D.C., Xu X., Wain J.C., Wiencke J.K. and Kelsey K.T. (1995) Glutathione $S$ transferase mu genotype, diet, and smoking as determinants of sister chromatid exchange frequency in lymphocytes. Cancer Epidemiol Biomarkers Prev, 4, 535-542.

51. Hardie, L.J., Briggs J.A., Davidson L.A., Allan J.M., King R.F., Williams G.I. and Wild C.P. (2000) The effect of hOGGI and glutathione peroxidase I genotypes and $3 \mathrm{p}$ chromosomal loss on 8 hydroxydeoxyguanosine levels in lung cancer. Carcinogenesis, 21, 167-172. 
52. Van Zeeland, A.A.. de Groot A.J., Hall J. and Donato F. (1999) 8-Hydroxydcoxyguanosine in DNA from leukocytes of healthy adults: relationship with cigarette smoking, environmental tobacco smoke, alcohol and coffee consumption. Murat Res, 439, 249-257.

53. Asami, S., Hirano T., Yamaguchi R., Tomioka Y., Itoh H. and Kasai H. (1996) Increase of a type of oxidative DNA damage, 8-hydroxyguanine, and its repair activity in human leukocytes by cigarettc smoking. Cancer Res, 56, 2546-2549.

54. Asami, S., Manabe H., Miyake J., Tsurudome Y., Hirano T., Yamaguchi R., Itoh H. and Kasai H. (1997) Cigarette smoking induces an increase in oxidative DNA damage, 8-hydroxydeoxyguanosine, in a central site of the human lung. Carcinogenesis, 18, 1763-1766.

55. Piperakis. S.M., Visvardis E.E., Sagnou M. and Tassiou A.M. (1998) Effects of smoking and aging on oxidative DNA damage of human lymphocytes. Carcinogenesis, 19, 695-698.

56. Loft, S., Vistisen K., Ewertz M., Tjonneland A., Overvad K. and Poulsen H.E. (1992) Oxidative DNA damage estimated by 8 -hydroxydeoxyguanosine excretion in humans: influence of smoking, gender and body mass index. Carcinogenesis, 13, 2241-2247.

57. Lof,, S., Fischer-Nielsen A., Jeding I.B., Vistisen K. and Poulsen H.E. (1993) 8Hydroxydeoxyguanosine as a urinary biomarker of oxidative DNA damage. $J$ Toxicol Environ Health, 40, 391-404.

58. Yin, B., Whyatt R.M., Perera F.P., Randall M.C., Cooper T.B. and Santella R.M. (1995) Detcrmination of 8-hydroxydeoxyguanosine by an immunoaffinity chromatography-monoclonal antibody-based ELISA. Free Radic Biol Med, 18, 1023-1032.

59. Loft, S., Poulsen H.E., Vistisen K. and Knudsen L.E. (1999) Increased urinary excretion of 8-oxo-2'deoxyguanosine, a biomarker of oxidative DNA damage, in urban bus drivers. Mutat Res, 441, 11-19.

60. Oesch, F., Aulmann W., Platt K.L. and Docrjer G. (1987) Individual differences in DNA repair capacities in man. Arch Toxicol Suppl, 10, 172-179.

61. Celotli, L., Ferraro P. and Biasin M.R. (1992) Detection by fluorescence analysis of DNA unwinding and unscheduled DNA synthesis, of DNA damage and repair induced in vitro by direct-acting mutagens on human lymphocytes. Mutat Res, 281, 17-23.

62. Kay, N.E. and Douglas S.D. (1990) Morphology and antigenic phenotype of human blood lymphocytes. In Williams, W.J., Beutler, E., Erslev, A.J. and Lichtman, M.A. (eds), Hematology. Vol. 4. McGraw-Hill, New York, pp. 905.

63. Shinmura, K., Kohno T., Kasai H., Koda K., Sugimura H. and Yokota J. (1998) Infrequent mutations of the $h O G G I$ gene, that is involved in the excision of 8-hydroxyguanine in damaged DNA, in human gastric cancer. Jpn J Cancer Res, 89, 825-828.

64. Sugimura. H., Kohno T., Wakai K., Nagura K., Genka K., Igarashi H., Morris B.J., Baba S., Ohno Y., Gao C., Li Z., Wang J., Takczaki T., Tajima K., Varga T., Sawaguchi T., Lum J.K., Martinson J.J., Tsugane S., Iwamasa T.. Shinmura K. and Yokota J. (1999) hOGGl Ser326Cys polymorphism and lung cancer susceptibility. Cancer Epidemiol Biomarkers Prev, 8, 669-674.

65. Kang, D., Nishida J., Iyama A., Nakabeppu Y., Furuichi M., Fujiwara T., Sckiguchi M. and Takeshigc K. (1995) Intracellular localization of 8-oxo-dGTPase in human cells, with special reference to the role of the enzyme in mitochondria, $J$ Biol Chem, 270, 14659-14665.

66. Mezzcti, A., Lapenna D., Pierdomenico S.D., Calafiore A.M., Costantini F., Riario-Sforza G., Imbastaro T., Neri M. and Cuccurullo F. (1995) Vitamins E, C and lipid peroxidation in plasma and arterial tissue of smokers and non-smokers. Atherosclerosis, 112, 91-99. 
67. Lykkesfeldt, J., Prieme H., Loft S. and Poulsen H.E. (1996) Effect of smoking cessation on plasma ascorbic acid concentration. Bmj, 313,91.

68. Sharpe, P.C., Duly E.B., MacAulcy D., McCrum E.E., Mulholland C., Stott G., Boreham C.A., Kennedy G., Evans A.E. and Trinick T.R. (1996) Total radical trapping antioxidant potential (TRAP) and exercise. Qjm, 89, 223-228.

69. Erhola, M., Nieminen M.M., Kcllokumpu-Lehtinen P., Metsa-Ketela T., Poussa T. and Alho H. (1997) Plasma peroxyl radical trapping capacity in lung cancer patients: a case-control study. Free Radic Res, 26, 439-447.

70. Nyyssonen, K., Porkkala-Sarataho E., Kaikkonen J. and Salonen J.T. (1997) Ascorbate and urate are the strongest determinants of plasma antioxidative capacity and serum lipid resistance to oxidation in Finnish men. Atherosclerosis, 130, 223-233.

71. Meijer, G.A.. Westerterp K.R., Saris W.H. and ten Hoor F. (1992) Sleeping metabolic rate in relation to body composition and the menstrual cycle. Am J Clin Nutr, 55, 637-640. 


\section{CHAPTER 7}

IMMUNOHISTOCHEMISTRY OF DNA ADDUCTS IN THE ORAL CAVITY 


\title{
Immunoperoxidase detection of polycyclic aromatic hydrocarbon-DNA adducts in mouth floor and buccal mucosa cells of smokers and non-smokers
}

\author{
A. Besarati Nia', H.W.M. Van Straaten', R.W.L. Godschalk', N. Van Zandwijk', A.J.M. Balm, \\ J.C.S. Kleinjans', F.J. Van Schooten".
}

'Department of Health Risk Analysis and Toxicology, Maastricht University, Maastricht, The Netherlands

'Department of Anatomy and Embryology, Maastricht University, Maastricht, The Netherlands

'Department of Chest Oncology, The Netherlands Cancer Institute, Amsterdam, The Netherlands

${ }_{4}^{4}$ Department of Otolaryngology, The Netherlands Cancer Institute, Amsterdam, The Netherlands

\begin{abstract}
Tobacco smoking is a major risk factor for oral cancer; mouth floor and buccal mucosa are among the most and least cancer prone subsites, respectively, in the oral cavity. We investigated the applicability of immunohistochemistry of smoking-induced DNA adducts in the oral cells for assessing the exposure to carcinogens and estimating the risk for oral cancer. Polycyclic aromatic hydrocarbon (PAH) -DNA adducts were measured in mouth floor and buccal mucosa cells of smokers $(n=26)$ and non-smokers $(n=22)$ by means of a semiquantitative immunoperoxidase assay. Smokers had elevated levels of PAH-DNA adducts as compared to non-smokers in their mouth floor cells $(0.045 \pm 0.022$ versus $0.022 \pm 0.016, \mathrm{P}=$ 0.0008 arbitrary units of immunohistochemistry) as well as in their buccal mucosa cells $(0.058 \pm 0.028$ versus $0.028 \pm 0.012, \mathrm{P}=0.001)$. There was a correlation between the levels of PAH-DNA adducts in mouth floor cells and those in buccal mucosa cells $(r=0.4, P=0.01)$. Further, PAH-DNA adduct levels in both mouth floor and buccal mucosa cells were significantly related to current smoking indices [tar/day and cigarette/day]. Expectedly, the levels of PAH-DNA adducts neither in mouth floor cells nor in buccal mucosa cells, both being short lived cells, were related to smoking history index [pack years]. The levels of PAHDNA adducts, however, in mouth floor cells as the cancer prone cells were lower than those in buccal mucosa cells $(0.037 \pm 0.023$ versus $0.044 \pm 0.026, P=0.04)$. We conclude that immunohistochemistry of PAH-DNA adducts in the oral cells can be used for exposure assessment of tobacco-related carcinogens; however, it per se cannot be used for oral cancer risk estimation.
\end{abstract}

Based on the manuscript published in:

"Eviron Mol Mutagen (2000) 36, 127-133" 


\section{Chapter Seven}

\section{Immunohistochemistry of DNA adducts in the oral cavity}

\section{INTRODUCTION}

Oral cancer is among the ten most frequent cancers worldwide (1) and its incidence is increasing over time particularly, in younger males $(2,3)$. This upward trend is mainly attributed to changes in tobacco and alcohol consumption (1-4). Case control studies have demonstrated dose- and time-dependent relationships between oral cancer incidence and tobacco and/or alcohol consumption (3-5). Moreover, it has been found that cancer susceptibility of various anatomic subsites in the oral cavity vary remarkably; epidemiological data imply that mouth floor and buccal mucosa are among the most and least cancer prone subsites, respectively, in the oral cavity $(3,5,6)$.

Tobacco smoke is a complex mixture of over 4000 chemicals, and of these about 50 including PAH, have proven to be carcinogenic in experimental animals $(7,8)$. Recent findings have implicated the contribution of $\mathrm{PAH}$ as probable causative agents to human oral cancer (9). PAH exert their biological effects through covalent binding of their reactive metabolites to cellular DNA forming DNA adducts $(10,11)$. Since formation of DNA adducts appears to be a key element in initiating carcinogenesis, examination of DNA for the presence of adducts could be used for assessing exposure to carcinogens as well as estimating risk for cancer (11).

Among the methods which have been developed for the quantification of carcinogenDNA adducts $(12,13)$, the immunohistochemical assay seems to be a suitable method for the study of DNA adducts in the oral cavity. Significant advantages of the assay for such study are its ability to detect particular class of carcinogen-DNA adducts at the individual cell level and its requirement for only small amount of cells (14-19).

In the present study, we investigated the applicability of immunohistochemistry of PAHDNA adducts in the oral cells for exposure assessment of tobacco-related carcinogens as well as risk estimation of oral cancer. For this purpose, we measured PAH-DNA adducts in mouth floor and buccal mucosa cells of smokers and non-smokers by means of a semi-quantitative immunoperoxidase assay applying the monoclonal antibody 5D11. Because this antibody has a proven specificity for recognizing DNA modified by specific diol epoxide derivative of benzo[a]pyrene (B[a]P) $(20,21)$, the representative of carcinogenic PAH (22), and because it cross-reacts slightly with some structurally related PAH diol epoxide-DNA adducts, the class of adducts recognized by it, can be classified as carcinogenic PAH-DNA adducts $(16,20,21)$. Our hypotheses for this study were (I) individuals' exposure to tobacco-associated carcinogens and their risk for oral cancer can manifest in immunohistochemistry of PAHDNA adducts in their oral cells and (II) cancer proneness of each subsite in the oral cavity can be reflected by immunohistochemistry of PAH-DNA adducts in situ. 


\section{MATERIAL AND METHODS}

\section{Study Population}

Volunteers were recruited into the study by advertising in the local newspapers. Upon enrollment, every individual signed an informed consent and filled out a comprehensive questionnaire seeking information on his/her age, sex, smoking behavior, alcohol consumption, medical history of disease, dietary/medicinal/occupational exposure to known carcinogens and familial history of cancer. Accordingly, two groups of healthy individuals consisted of 26 smokers [age, $44 \pm 9$ years; smoking, $27 \pm 13$ cigarettes/day] and 22 lifetime non-smokers [age, $40 \pm 11$ years] having no occupational exposure to tobacco-related carcinogens were selected. Table I summarizes the characteristics of the study population. The study was approved by the Medical Ethical Commission of the Netherlands Cancer Institute.

Table I. Characteristics of the study population and summary of DNA adducts analysis

\begin{tabular}{|l||c||c|}
\hline & Smokers & Non-smokers \\
\hline \hline Number & 26 & 22 \\
\hline Gender (male/female) & $8 / 18$ & $5 / 17$ \\
\hline Age & $44 \pm 9$ & $40 \pm 11$ \\
\hline Cigarettes/day & $27 \pm 13$ & 0 \\
\hline Tar/day (mg) & $415 \pm 278$ & 0 \\
\hline PAH-DNA adducts in mouth floor & $\begin{array}{l}0.045 \pm 0.022^{\circ} \\
\text { Range: } 0.024-0.071\end{array}$ & $\begin{array}{l}0.022 \pm 0.016 \\
\text { Range: } 0.004-0.048\end{array}$ \\
\hline PAH-DNA adducts in buccal mucosa & $\begin{array}{l}0.058 \pm 0.028^{\circ} \\
\text { Range: } 0.026-0.096\end{array}$ & $\begin{array}{l}0.028 \pm 0.012 \\
\text { Range: } 0.011-0.043\end{array}$ \\
\hline
\end{tabular}

${ }^{3}$ Arbitrary units of immunohistochemistry.

'Statistically significant compared to non-smokers, $\mathrm{P}=0.0008$.

'Statistically' significant compared to non-smokers, $\mathrm{P}=0.001$. 


\section{Sampling, Processing and Cytospin Preparation}

To ensure collection of cells from the appropriate anatomic subsites in the oral cavity, sampling was performed by an otholaryngologist or a well-trained staff. Mouth floor and buccal mucosa cells were harvested by brushing precisely the floor of the mouth and the middle part of the inside of the cheek, respectively, with an interdental brush (Lactona, Almere, the Netherlands). The brushes were stirred in 10-ml Greiner tubes (Greiner Labortechnik, Frickenhausen, Germany) pre-filled with $5 \mathrm{ml}$ phosphate buffered saline (PBS), $\mathrm{pH}$ 7.4, allowing the cells to detach from the brushes. Cell suspensions were centrifuged, resuspended in PBS and filtered through Polyamide Gauze [100 micron mesh opening] (Stokvis \& Smits $B V$, IJmuiden, the Netherlands). The filtrates were pelleted by centrifugation, resuspended in PBS and stored at $-70^{\circ} \mathrm{C}$ until cytospinning. Prior to cytospin preparation, the frozen samples were thawed for $20 \mathrm{~min}$ at room temperature. The cell suspensions were cytocentrifuged at $1500 \mathrm{rpm}$ for 5 min (Shandon Cytospin ${ }^{\oplus}$, Cheshire, UK) onto Polysine ${ }^{\mathrm{TM}}$ microslides (E. Merck Nederland B.V., Amsterdam, the Netherlands). The slides were air dried for $1 \mathrm{~h}$ and subsequently, fixed in acetone at $-20^{\circ} \mathrm{C}$ for $20 \mathrm{~min}$.

\section{Treatment of Buccal Mucosa Cells with ( \pm )-anti-BPDE}

Two aliquots from the buccal mucosa cells of a non-smoker [harvested by multiple brushing, $1 \times 10^{6}$ cells each] were treated in vitro with 0 and $20 \mu \mathrm{M} 7 \beta, 8 \alpha$-dihydroxy-9 $\alpha, 10 \mathrm{a}$-epoxy7,8,9,10-tetrahydrobenzo[a]pyrene, (( \pm )-anti-BPDE) (Midwest Research Institute, Kansas city, MO) in anhydrous dimethylsulfoxide (DMSO) for $45 \mathrm{~min}$ at $37^{\circ} \mathrm{C}$ in the dark. Final concentration of DMSO in cell suspension was $0.05 \%$. Cytotoxicity was determined using trypan blue exclusion technique. Cells were washed twice with PBS and subsequently, cytospin preparation was done as described above. The prepared slides were used for evaluating the sensitivity and specificity of immunoperoxidase staining in all experiments as well as for standardizing the results from different sets of experiments.

\section{Immunohistochemistry of PAH-DNA Adducts}

Fixed slides were rehydrated with PBS and boiled in prewarmed $\left[37^{\circ} \mathrm{C}\right] 100 \mathrm{mM}$ Citric Acid, $\mathrm{pH} 6.0 \mathrm{in}$ a microwave oven for $10 \mathrm{~min}$. The slides were cooled down to room temperature for $30 \mathrm{~min}$, rinsed with tap water and re-rinsed with PBS for $2 \times 5 \mathrm{~min}$. Subsequently, they were treated with $100 \mu \mathrm{g} / \mathrm{ml}$ RNase A in Tris buffer [ $10 \mathrm{mM}$ Tris, $1 \mathrm{mM}$ EDTA, $400 \mathrm{mM} \mathrm{NaCl}$, $\mathrm{pH} 7.5]$ for $1 \mathrm{~h}$ at $37^{\circ} \mathrm{C}$ and then, rinsed with PBS for $2 \times 5 \mathrm{~min}$. Proteinase $\mathrm{K}[10 \mu \mathrm{g} / \mathrm{ml}$ in Tris buffer] treatment of the slides was done for $10 \mathrm{~min}$ at room temperature, followed by a rinse with PBS. The slides were immersed in $4 \mathrm{~N} \mathrm{HCl}$ for 7 min to denature DNA, treated with $50 \mathrm{mM}$ Tris base for $5 \mathrm{~min}$ at room temperature and rinsed with PBS for $2 \times 5 \mathrm{~min}$. In order to block the non-specific binding of primary antibody, the slides were pre-incubated in $2 \%$ 
Bovine Albumin (Brunschwig, Amsterdam, the Netherlands) for $45 \mathrm{~min}$ at $37^{\circ} \mathrm{C}$. Subsequent incubation of the slides with primary antibody 5D11 (kindly provided by Dr. R. Santella) [diluted 1:150 in $2 \%$ Bovine Albumin] was done overnight at $4^{\circ} \mathrm{C}$. The following day, the slides were rinsed with PBS for $3 \times 5$ min and incubated with biotinylated Anti-Mouse IgG $\left[\mathrm{H}+\mathrm{L}\right.$ ] (Brunschwig) [diluted 1:200 in $2 \%$ Bovine Albumin] for $30 \mathrm{~min}$ at $37^{\circ} \mathrm{C}$. Being rinsed with PBS, the slides were treated with $0.3 \% \mathrm{H}_{2} \mathrm{O}_{2}$ in methanol for $30 \mathrm{~min}$ at room temperature to quench the endogenous peroxidase activity and then, rinsed with PBS for $2 \times 5$ min. Immunoperoxidase staining of the slides was done applying a VECTASTAIN ${ }^{\circledR} \mathrm{ABC}$ system [Avidin DH + biotinylated horse-radish peroxidase $\mathrm{H}$ ] (Brunschwig). The stained slides were rinsed with PBS, dipped into $1 \%$ Triton X-100 (Merck, Darmstadt, Germany) for $30 \mathrm{sec}$ and re-rinsed with PBS. Visualization of the peroxidase staining was achieved using a 3, 3'-diaminobenzidine (DAB) substrate kit [DAB + nickel chloride] according to the instructions of the manufacturer (Brunschwig). The slides were rinsed with tap water, dehydrated with serial ethanol and finally, cleaned with xylene.

Quantification was done applying an Image Processing and Analysis System (Quantimet 500 , Leica, Cambridge, UK) through measuring the relative intensities of staining in nuclear, cytoplasmic and extracellular [background] areas in 200 morphologically well-defined cells per slide; our validation experiments have shown that quantification of 200 cells per slide can prevent over- or under-estimation of staining, which may occur due to the heterogeneity of staining. Stain intensities of nucleus and cytoplasm were divided by that of extracellular area in order to obtain nucleic and cytoplasmic transmissions, respectively. Negative logarithm of transmission was taken to calculate absorbance, which in turn, is linearly related to stain density. The stain density of cytoplasm was subtracted from that in nucleus to correct for background density of staining. In principle, as stain density in the nucleus is proportional to the level of DNA adducts, the corrected nucleic stain density in every individual cell represented its DNA adducts level [range, $0.00-2.40$ arbitrary units].

To evaluate the intra-assay variation, buccal mucosa cells of smokers and non-smokers were assayed in duplicate. The intra-assay coefficient of variation was $12.0 \pm 7.5 \% \quad(n=8)$. Assessment of the inter-assay variation was done by assaying mouth floor and buccal mucosa cells of smokers and non-smokers in three independent experiments. The inter-assay coefficient of variation was $9.6 \pm 8.4 \%(n=10)$. Sensitivity and specificity of the staining in all experiments were checked by examining the control slides [made of buccal mucosa cells treated in vitro with and without ( \pm -anti-BPDE]. Additional examination of the specificity included re-staining of the most heavily stained slides from both smokers and non-smokers in each set of experiments either after pre-treatment with DNase I (Amersham Pharmacia Biotech, Piscataway, NJ) $[0.5 \mathrm{U} /$ slide $]$ for $45 \mathrm{~min}$ at $37^{\circ} \mathrm{C}$ or after omission of the primary antibody. In neither case, nucleic stain density could measurably exceed cytoplasmic density of staining throughout the slide. 


\section{Statistical Analysis}

Results were expressed as mean \pm standard deviation. In all cases, comparisons were made using Student's $t$-test. Simple linear regression analysis was performed to study the relationships between different variables. Statistical significance was considered at $P<0.05$.

\section{RESULTS}

Immunohistochemistry of PAH-DNA adducts in mouth floor cells showed significantly higher levels of adducts in smokers as compared to non-smokers $(0.045 \pm 0.022$ versus $0.022 \pm 0.016, P=0.0008$ ). Distribution of the levels of adducts in mouth floor cells of smokers and non-smokers is presented in Figure 1.

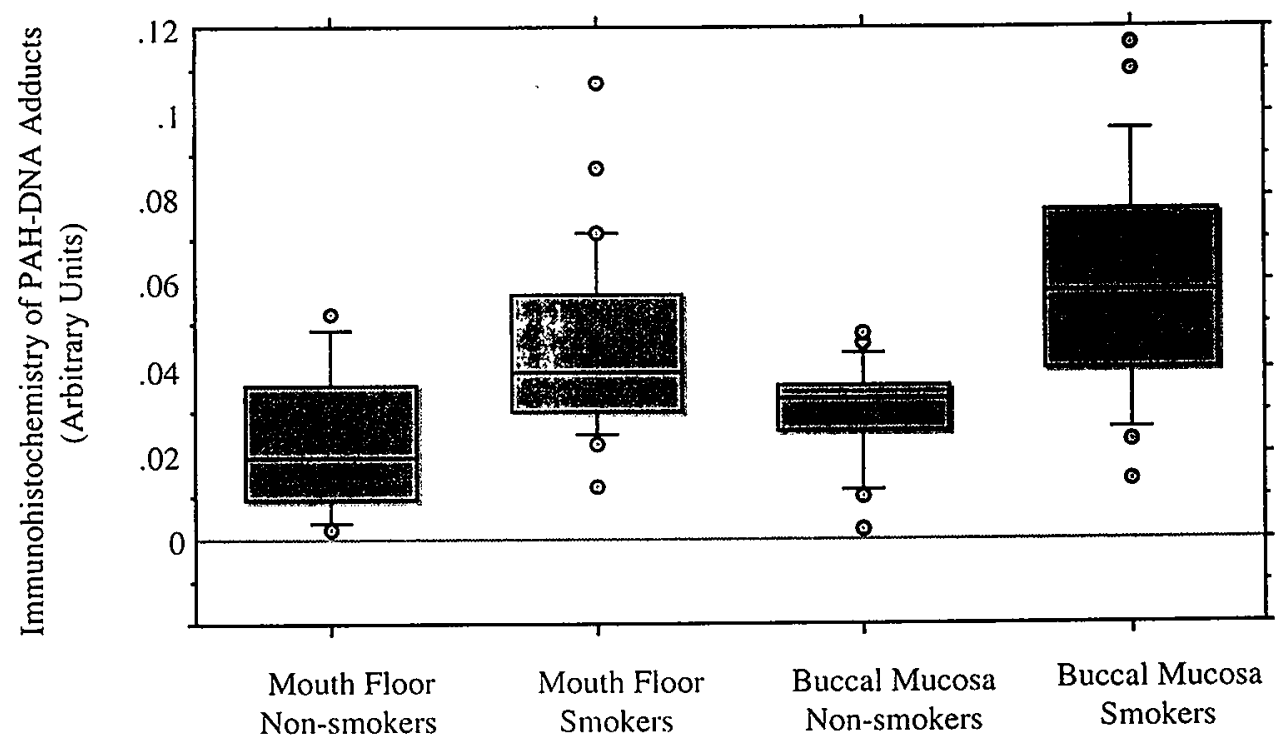

Fig. 1. Distribution of the levels of PAH-DNA adducts in mouth floor and buccal mucosa cells of smokers and non-smokers. The lower and upper edges of the boxes, the $25^{\text {th }}$ and the $75^{\text {th }}$ percentiles, respectively. within the boxes, the medians. Lower and upper bars, the $10^{\text {th }}$ and the $90^{\text {th }}$ percentiles, respectively. 0 , Individual values $<10^{\text {th }}$ or $>90^{\text {th }}$ percentiles. 
Adduct levels in mouth floor cells of smokers and non-smokers ranged from 0.024 to 0.071 , and from 0.004 to 0.048 , respectively [Tab. I]. Figure 2 [A, B] shows the representatives of immunoperoxidase staining in mouth floor cells of a smoker and a non-smoker.
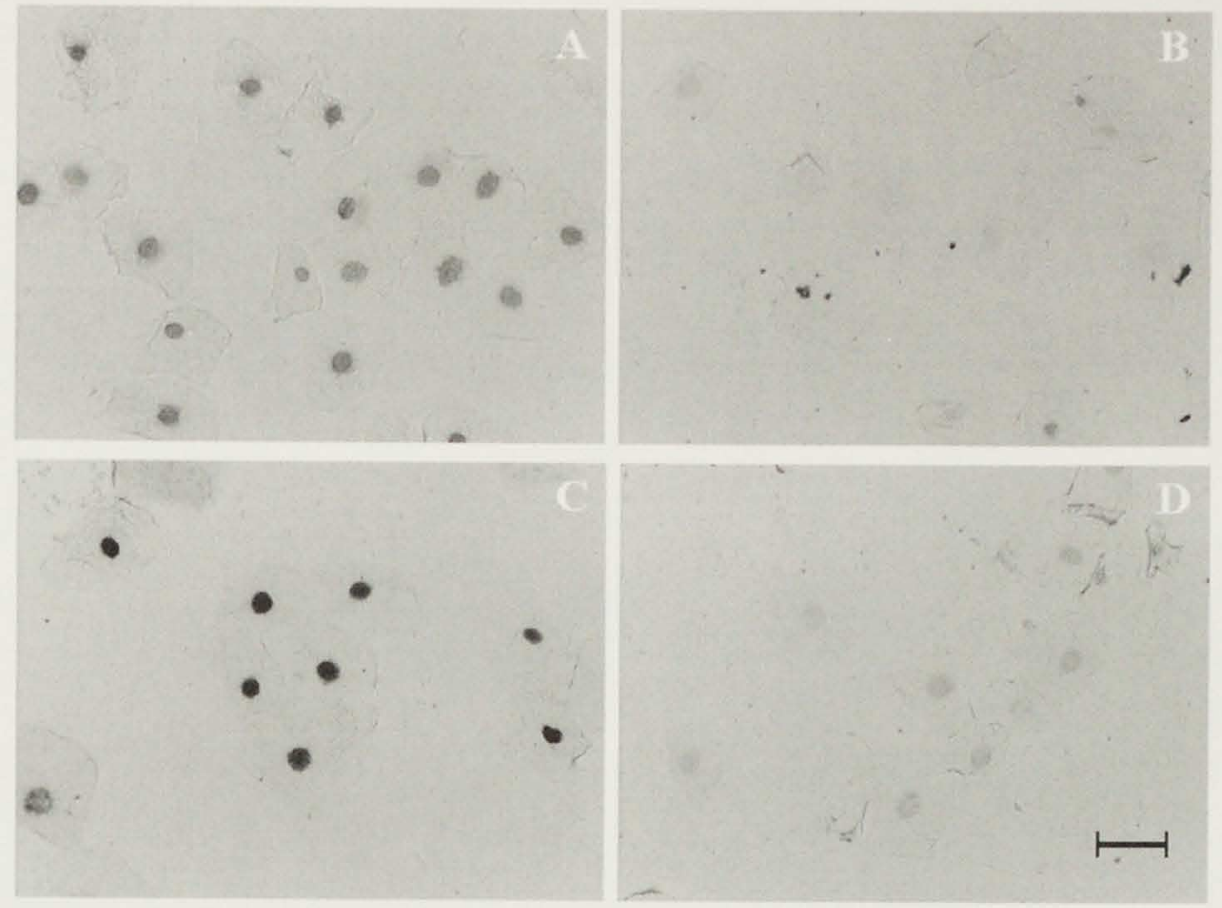

Fig. 2. Immunoperoxidase staining of PAH-DNA adducts in mouth floor and buccal mucosa cells of a smoker (A, C, respectively) and a non-smoker (B, D, respectively). bar, $50 \mu \mathrm{m} . \times 800$ magnification.

Similarly, immunohistochemistry of PAH-DNA adducts in buccal mucosa cells revealed significantly higher levels of adducts in smokers as compared to non-smokers $(0.058 \pm 0.028$ versus $0.028 \pm 0.012, P=0.001$ ). Figure 1 illustrates the distribution of the levels of adducts in smokers and non-smokers. Adduct levels in buccal mucosa cells of smokers and nonsmokers varied in the ranges of $0.026-0.096$ and $0.011-0.043$, respectively [Tab. I]. Representatives of the immunoperoxidase staining in buccal mucosa cells of a smoker and a non-smoker are shown in Figure 2 [C, D].

Overall, in smokers and non-smokers there was a significant correlation between the levels of adducts in mouth floor cells and those in buccal mucosa cells $(r=0.4, P=0.01)$. However, such correlation was not observed in smokers or in non-smokers, separately. Also, the levels of adducts in mouth floor cells of the overall smokers and non-smokers were significantly lower than those in buccal mucosa cells $(0.037 \pm 0.023$ versus $0.044 \pm 0.026$, 
$\mathrm{P}=0.04)$. Such difference, however, could not reach a statistically significant level either in smokers $(0.045 \pm 0.022$ versus $0.058 \pm 0.028, \mathrm{P}=0.13)$ or in non-smokers, individually $(0.022 \pm 0.016$ versus $0.029 \pm 0.012, \mathrm{P}=0.17)$ [Fig. 1].

Overall, adduct levels in mouth floor and buccal mucosa cells were significantly related to current smoking indices [number of cigarettes smoked per day and amount of tar consumed per day]. Tar consumption per day was calculated as tar content of cigarette [mg] multiplied by number of cigarettes smoked per day. Figure $3[\mathrm{~A}, \mathrm{~B}]$ illustrates the relationships between the levels of adducts in mouth floor cells and both the number of cigarettes smoked per day $(r=0.5, P=0.002)$ and the amount of tar consumed per day $(r=0.7, P=0.0001)$.

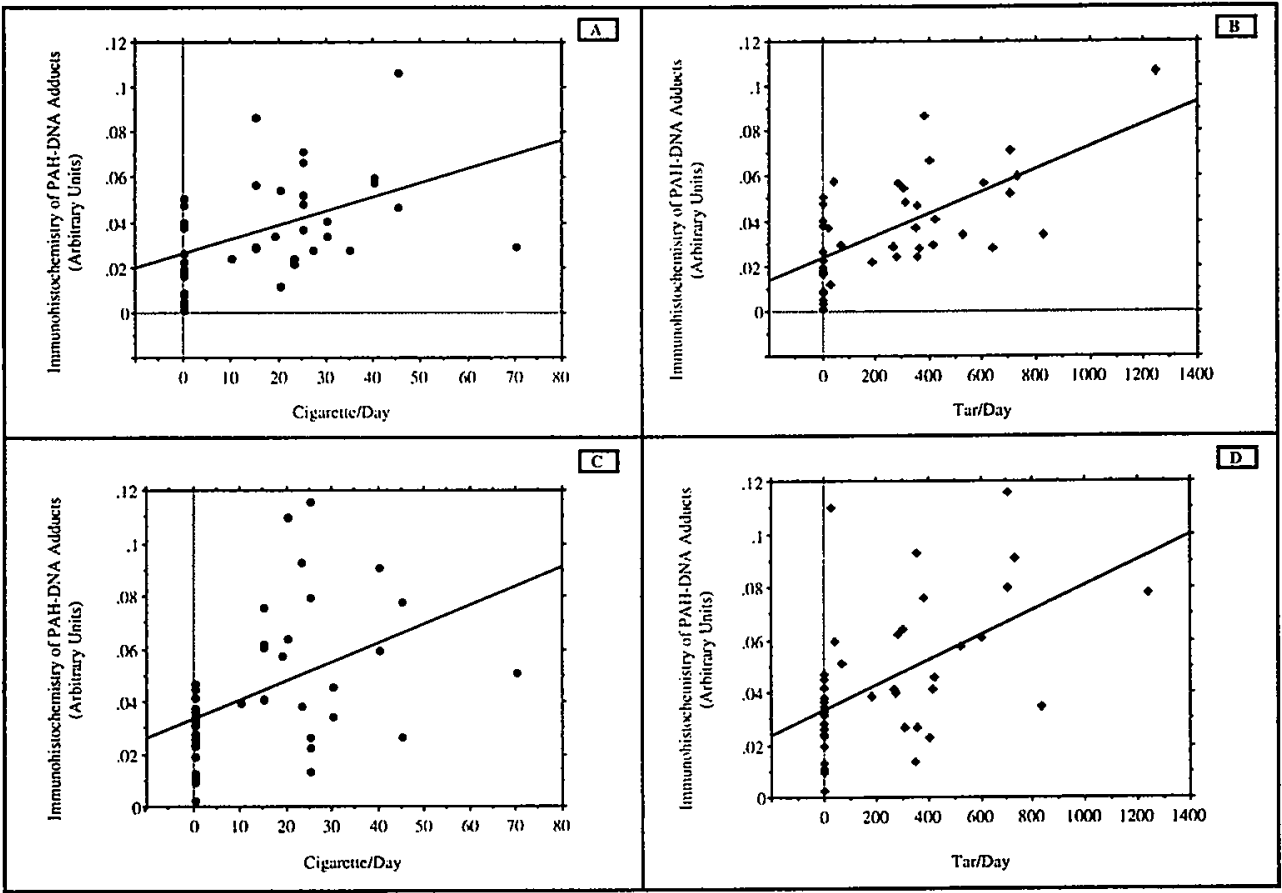

Fig. 3. Correlation between the number of cigarettes smoked per day and the amount of tar consumed per day, and the level of PAH-DNA adducts in mouth floor cells $(\mathrm{A}, \mathrm{r}=0.5, \mathrm{P}=0.002$ and $\mathrm{B}, \mathrm{r}=0.7, \mathrm{P}=0.0001$, respectively) and in buccal mucosa cells $(C, r=0.5, P=0.001$ and $D, r=0.5, P=0.0002$, respectively). 
The relationships between the levels of adducts in buccal mucosa cells and the number of cigarettes smoked per day $(r=0.5, P=0.001)$ and the amount of tar consumed per day $(r=0.5$, $\mathrm{P}=0.0002$ ) are shown in Figure $3[C, D]$. Excluding the non-smokers from these analyses, we could only establish a significant dose-response relationship between the levels of adducts in mouth floor cells and the amount of tar consumed per day $(r=0.6, P=0.004)$. There was not any correlation between the levels of adducts in mouth floor cells nor in buccal mucosa cells, and smoking history index [pack years, number of cigarettes smoked per day/20 $\mathrm{X}$ smoking years].

\section{DISCUSSION}

Ample evidence has unequivocally shown that smokers are at high risk of developing oral cancer (1-3). It has also been demonstrated that cancer susceptibility of different subsites in the oral cavity vary notably; mouth floor and buccal mucosa being among the most and least cancer prone subsites, respectively $(3,5,6)$. Recent investigations on tobacco smoke carcinogenicity have implied the involvement of $\mathrm{PAH}, \mathrm{B}[\mathrm{a}] \mathrm{P}$ being the most commonly used representative of them (22), in oral cancer (9). Hypothetically, pooling of saliva into the salivary gland ducts located in the floor of mouth exposes this region to the inhaled and/or ingested carcinogens, thereby making it a cancer susceptible subsite in the oral cavity $(23,24)$. In the present study, we performed the immunohistochemistry of PAH-DNA adducts in the oral cells in relation to exposure to tobacco smoke and susceptibility to oral cancer at both individual level [smokers versus non-smokers] as well as within the individual [mouth floor cells versus buccal mucosa cells].

We observed higher levels of PAH-DNA adduct in both mouth floor and buccal mucosa cells of smokers as compared to non-smokers. This is in line with the findings of other studies quantifying PAH-DNA adducts in oral mucosa cells [non-locally] of smokers and non-smokers (16-18). Although our different method of quantification [specifically designed for our image analyzer] resulted in lower determination of the level of adducts; proportionally, our data are comparable to the reported results. In fact, we measured approximately 2-fold higher level of adducts in both mouth floor and buccal mucosa cells of smokers than nonsmokers, and further a wide inter-individual range in the level of adducts in both smokers and non-smokers (16-18). The wide variation in the level of adducts could be ascribed to the differences in activating/detoxifying pro-carcinogens and repairing damaged DNA at the individual level (25-27). We should also emphasize that the determined level of adducts in non-smokers could mainly reflect their exposure to other sources of PAH e.g., diet, environmental tobacco smoke, etc. (28) because our specificity examination ensured the PAHderived nature of these adducts. Furthermore, we observed a significant correlation between the levels of adducts in mouth floor cells and those in buccal mucosa cells in the overall study group. This might be attributed to the similar exposure pattern for these cells as both mouth floor and buccal mucosa cells are exposed to almost same sources of carcinogens via identical routes. The lack of such correlation in smokers or in non-smokers, separately, could be due to the insufficient number of subjects per group. Moreover, we found dose-response 
relationships between the levels of adducts in both mouth floor and buccal mucosa cells, and current exposure to tobacco smoke [cigarettes/day and tar/day] in the overall study group. Although one might argue the validity of these indices as compared to the internal dose markers e.g., urinary cotinine (29), their reliability upon administration of a standardized questionnaire has already been verified (30-32). It is noteworthy that in this study tar consumption per day was a more relevant exposure index. This could relate to the fact that PAH are predominantly present in the tar content of tobacco smoke (9). Interestingly, the more pronounced dose-dependency of adducts in both mouth floor and buccal mucosa cells with regard to the amount of tar consumed per day as compared to the number of cigarettes smoked per day supports this idea. We acknowledge that like most other studies (33), these dose-response relationships were partially dependant upon the contribution of non-smokers. Nonetheless, given the limited number of smokers and the wide inter-individual variations in their adduct levels, this would be statistically justifiable (34). It is also worthy mentioning that even after excluding the non-smokers, adduct levels were dose dependent in mouth floor cells [the target cell type for oral cancer], but not in buccal mucosa cells. This is in good conformity with other studies demonstrating such dose-response relationships only in the cells from the target sites e.g., lung, larynx, but not from the surrogate ones e.g., blood cells (35-37). Regarding the cumulative dose of exposure, lack of relation between adduct levels in either mouth floor cells or buccal mucosa cells and smoking history index [pack years] was not unexpected. Indeed, oral cells are exfoliated cells with a short life span of a few days to a week (38); thus, formation of DNA adducts in these cells can merely be explained by a recent exposure to tobacco smoke. Taken together, from the standpoint of exposure, our data suggest that not only are the levels of adducts in oral cells related to exposure to tobacco smoke, but they also correspond with the magnitude of such exposure.

Furthermore, we observed that smokers as the susceptible individuals to oral cancer, had higher levels of adducts in their oral cells as compared to non-smokers. However, adduct levels were lower in mouth floor cells as the more cancer prone cells, compared to buccal mucosa cells. This questions the validity of immunohistochemistry of PAH-DNA adducts for oral cancer risk assessment. Assumingly, the elevated level of adducts in smokers is a consequence of their exposure to PAH rather than a pre-requisite for their susceptibility to oral cancer. We should, however, acknowledge that the herein immunohistochemistry of PAHDNA adducts was specific for only one of the eleven carcinogenic PAH, the B[a]P (39). Thus, we cannot rule out the possibility that other carcinogenic PAH in tobacco smoke e.g., benzo[a]anthracene, benzo[b]fluoranthene (39) being un- / under-detected by our assay might be of more relevance for oral cancer. Of course, we substantially ruled out the possibility that different spectra of PAH-DNA adducts with varying carcinogenic potency could have been quantified in smokers versus non-smokers, and in mouth floor cells versus buccal mucosa cells. This was demonstrated by our specificity examination on the primary antibody. It should also be taken into account that DNA adducts formation is merely one stage in the multi-stage process of carcinogenesis. Therefore, we may consider that other influential factors such as DNA repair and cellular proliferation $(40,41)$ together with or separate from DNA adduct formation, can modulate oral carcinogenesis. Altogether, it appears that with the existing inefficiency in the methodology, it is pre-mature to rely solely on the immunohistochemistry of PAH-DNA adducts for oral cancer risk estimation. Prospectively, it 
is worthwhile coupling this study with an investigation on DNA repair capacity and cellular proliferation rate in cells from different regions of the oral cavity.

In conclusion, we have demonstrated that immunohistochemistry of PAH-DNA adducts in the oral cells can be used for assessing the exposure to tobacco-related carcinogens; however, it cannot per se be used for estimating the risk for oral cancer.

$* * * * * * * * *$ 


\section{REFERENCE}

1. Boyle, P., Macfarlane G.J. and Scully C. (1993) Oral cancer: necessity for prevention strategies. Lancet, 342, 1129.

2. Hindle, I., Downer M.C. and Speight P.M. (1996) The epidemiology of oral cancer. Br J Oral Maxillofac Surg, 34, 471-476.

3. Negri, E., La Vecchia C., Levi F., Franceschi S., Serra-Majem L. and Boyle P. (1996) Comparative descriptive cpidemiology of oral and oesophageal cancers in Europe. Eur J Cancer Prev, 5, 267-279.

4. O'Hanlon, S., Forster D.P. and Lowry R.J. (1997) Oral cancer in the North-East of England: incidence, mortality trends and the link with material deprivation. Community Dent Oral Epidemiol, 25, 371-376.

5. Hicks, W.L., Jr., Lorec T.R., Garcia R.I., Maamoun S., Marshall D., Orner J.B., Bakamjian V.Y. and Shedd D.P. (1997) Squamous cell carcinoma of the floor of mouth: a 20-year revicw. Head Neck, 19. 400-405.

6. Swango, P.A. (1996) Cancers of the oral cavity and pharynx in the Unitcd States: an epidemiologic overview. J Public Health Dent, 56, 309-318.

7. Patrikanos, C. and Hoffmann D. (1979) Chemical studies on tobacco smoke. I Anal Toxicol, 3, 184197.

8. International Agency for Research on Cancer (1986) Tobacco smoking. In Monographs on the evaluation of the carcinogenic risk of chemicals to humans. Vol. 38. Intcrnational Agency for Research on Cancer, Lyon (France), pp. 37-375.

9. Hoffmann, D. and Hoffmann I. (1997) The changing cigarette, 1950-1995. J Toxicol Environ Health, 50. 307-364.

10. Miller, E.C. and Miller J.A. (1981) Searches for ultimate chemical carcinogens and their reactions with cellular macromolecules. Cancer, 47, 2327-2345.

11. Hemminki, K. (1993) DNA adducts, mutations and cancer. Carcinogenesis, 14, 2007-2012.

12. Santella, R.M. (1991) DNA adducts in humans as biomarkers of exposure to environmental and occupational carcinogens. Environ Carcino \& Ecotox Revs, C9, 58-81.

13. Talaska, G., Schamer M., Skipper P., Tannenbaum S., Caporaso N., Kadlubar F., Bartsch H. and Vineis P. (1993) Carcinogen-DNA adducts in exfoliated urothelial cells: techniques for noninvasive human monitoring. Environ Healh Perspect, 99, 289-291.

14. Poirier, M.C. (1993) Antisera specific for carcinogen-DNA adducts and carcinogen-modified DNA: applications for detection of xenobiotics in biological samples. Mutat Res, 288, 31-38.

15. Molykicwicz, G., Malusecka E., Grzybowska E., Chorazy M., Zhang Y.J., Perera F.P. and Santella R.M. (1995) Immunohistochemical quantitation of polycyclic aromatic hydrocarbon-DNA adducts in human lymphocytcs. Cancer Res, 55, 1417-1422.

16. Zhang, Y.J., Hsu T.M. and Santella R.M. (1995) Immunoperoxidase delection of polycyclic aromatic hydrocarbon-DNA adducts in oral mucosa cells of smokers and nonsmokers. Cancer Epidemiol Biomarkers Prev, 4, 133-138.

17. Hsu. T.M., Zhang Y.J. and Santella R.M. (1997) Immunoperoxidase quantitation of 4-aminobiphenyland polycyclic aromatic hydrocarbon-DNA adducts in exfoliated oral and urothelial cells of smokers and nonsmokers. Cancer Epidemiol Biomarkers Prev, 6, 193-199.

18. Romano. G., Sgambato A., Boninsegna A., Flamini G., Curigliano G., Yang Q., La Gioia V., Signorelli C., Ferro A., Capelli G., Santella R.M. and Cittadini A. (1999) Evaluation of polycyclic 
aromatic hydrocarbon-DNA adducts in exfoliated oral cells by an immunohistochemical assay. Cancer Epidemiol Biomarkers Prev, 8, 91-96.

19. Romano, G., Mancini R., Fedele P., Curigliano G., Flamini G., Giovagnoli M.R., Malara N., Boninsegna A., Vecchione A., Santella R.M. and Cittadini A. (1997) Immunohistochemical analysis of 4-aminobiphenyl-DNA adducts in oral mucosal cells of smokers and nonsmokers. Anticancer Res, 17. 2827-2830.

20. Santella, R.M., Lin C.D., Cleveland W.L. and Weinstein I.B. (1984) Monoclonal antibodies to DNA modified by a benzo[alpyrene diol cpoxide. Carcinogenesis, 5, 373-377.

21. Santella, R.M., Dharmaraja N., Gasparro F.P. and Edclson R.L. (1985) Monoclonal antibodies to DNA modificd by 8-methoxypsoralen and ultraviolet A light. Nucleic Acids Res, 13, 2533-2544.

22. Hall, M. and Grover P.L. (1990) Polycyclic aromatic hydrocarbons: metabolism, activation and tumour initiation. In Cooper, C.S. and Grover, P.L. (eds), Chemical carcinogenesis and mutagenesis I. Vol. 94/l. Springer-Verlag, Berlin-Heidelberg, pp. 327-372.

23. Ord, R.A. and Lec V.E. (1996) Submandibular duct repositioning after excision of floor of mouth cancer. J Oral Maxillofac Surg, 54, 1075-1079.

24. Daley, T.D., Lovas J.G., Peters E., Wysocki G.P. and McGaw T.W. (1996) Salivary gland duct involvement in oral epithelial dysplasia and squamous cell carcinoma. Oral Surg Oral Med Oral Pathol Oral Radiol Endod, 81, 186-192.

25. Singh, N.P., Danner D.B., Tice R.R., Brant L. and Schneider E.L. (1990) DNA damage and repair with age in individual human lymphocytes. Mutat Res, 237, 123-130.

26. Wei, Q. and Spit\% M.R. (1997) The role of DNA repair capacity in susceptibility to lung cancer: a review. Cancer Metasiasis Rev, 16, 295-307.

27. Butkiewicz, D., Grzybowska E., Hemminki K., Ovrebo S., Haugen A., Motykiewicz G. and Chorazy M. (1998) Modulation of DNA adduct levels in human mononuclear whitc blood cells and granulocytes by CYP1A1. CYP2D6 and GSTMI genctic polymorphisms. Mutal Res, 415, 97-108.

28. Scherer, G. and Richter E. (1997) Biomonitoring exposure to environmental tobacco smoke (ETS): a critical rcappraisal. Hum Exp Toxicol, 16, 449-459.

29. Benowitz, N.L., Kuyt F., Jacob P.d., Jones R.T. and Osman A.L. (1983) Cotinine disposition and effects. Clin Pharmacol Ther, 34, 604-611.

30. Percz-Stable, E.J., Benowitz N.L. and Marin G. (1995) Is serum cotinine a better mcasure of cigarette smoking than self- report? Prev Med, 24, 171-179.

31. Klebanoff, M.A., Levine R.J., Clemens J.D., DerSimonian R. and Wilkins D.G. (1998) Serum cotinine concentration and self-reported smoking during pregnancy. Am J Epidemiol, 148, 259-262.

32. Parazzini, F., Davoli E., Rabaiotti M., Restelli S., Stramare L., Dindelli M., La Vecchia C. and Fanelli R. (1996) Validity of self-reported smoking habits in pregnancy: a saliva cotinine analysis. Acta Obstet Gynecol Scand, 75, 352-354.

33. Kriek, E., Rojas M.. Alexandrov K. and Bartsch H. (1998) Polycyclic aromatic hydrocarbon-DNA adducts in humans: relcvance as biomarkers for exposure and cancer risk. Mutat Res, 400, 215-231.

34. Altman, D.G. (1991) Clinical trails. In Altman, D.G. (ed.), Practical statistics for medical research. (1 edn). Chapman and Hall, London, pp. 440-476.

35. Lewtas, J., Mumford J., Everson R.B., Hulka B., Wilcosky T., Kozumbo W., Thompson C., George M., Dobias L., Sram R. and et al. (1993) Comparison of DNA adducts from exposurc to complex mixtures in various human tissues and experimental systems. Environ Health Perspect, 99, 89-97. 
36. Randerath, E. and Randerath K. (1993) Monitoring tobacco smoke-induced DNA damage by ${ }^{32} \mathrm{P}-$ postlabelling. IARC Sci Publ, 124, 305-314.

37. Phillips, D.H. (1996) DNA adducts in human tissues: biomarkers of exposure to carcinogens in tobacco smoke. Environ Health Perspect, 104 Suppl 3, 453-458.

38. Stich, H.F., San R.H. and Rosin M.P. (1983) Adaptation of the DNA-repair and micronucleus tests to human cell suspensions and exfoliated cells. Amn N Y Acad Sci, 407, 93-105.

39. International Agency for Research on Cancer (1983) Monographs on the evaluation of the carcinogenic risk of chemicals to humans, Part 1. Vol. 38. International Agency for Research on Cancer, Lyon (France).

40. Kulkarni, M.S., Angerman-Stewart J. and Anderson M.W. (1984) Detection of in vivo DNA repair synthesis in mouse liver and lung induced by treatment with benzo[a]pyrene or 4-nitroquinoline 1-oxide. Cancer Res, 44, 1547-1550.

41. Van Schooten, F.J., Hillebrand M.J., Scherer E., den Engelse L. and Kriek E. (1991) Immunocytochemical visualization of DNA adducts in mouse tissues and human white blood cells following treatment with benzo[alpyrene or its diol epoxide. A quantitative approach. Carcinogenesis, 12. 427-433. 


\section{CHAPTER 8}

CHEMOPREVENTION TRIAL OF $N$-ACETYL-L-CYSTEINE 


\title{
Effects of oral administration of $\mathrm{N}$-acetyl-L-cysteine: a multi-biomarker study in smokers
}

F.J. Van Schooten', A. Besarati Nia', S. De Flora², F. D'Agostini², A. Izzotti', A. Camoirano², A.J.M. Balm ${ }^{3}$, J.W. Dallinga', A. Bast', G.R.M.M. Haenen', L. Van't Veer', P. Baas, H. Sakai ${ }^{4}$, N. Van Zandwijk ${ }^{\circ}$

\footnotetext{
'Department of Health Risk Analysis and Toxicology, Maastricht University, Maastricht, The Netherlands

${ }^{2}$ Department of Health Sciences, University of Genoa, Genoa, Italy

'Department of Otolaryngology, The Netherlands Cancer Institute, Amsterdam, The Netherlands "Department of Pharmacology and Toxicology, Maastricht University, Maastricht, The Netherlands

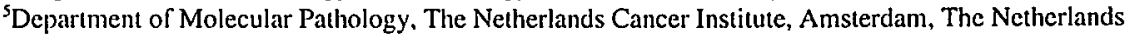

"Department of Thoracic Oncology, The Netherlands Cancer Institute, Amsterdam, The Netherlands

'Department of Thoracic Surgery, Tokyo University, Tokyo, Japan
}

\begin{abstract}
$\mathrm{N}$-acetyl-L-cysteine (NAC) has been shown to exert cancer protective mechanisms and effects in experimental models. We report here the results of a randomized double blind placebo controlled phase II chemoprevention trial with NAC in healthy smoking volunteers. The subjects were supplemented daily with $2 \times 600 \mathrm{mg}$ oral tablets of NAC $(n=20)$ or placebo $(n=$ 21) for a period of six months, and internal dose markers [plasma and bronchoalveolar lavage (BAL) fluid cotinine and urine mutagenicity], biologically effective dose markers [smokingrelated DNA adducts and hemoglobin $(\mathrm{Hb})$ adducts] and biological response markers [micronuclei frequency and antioxidants scavenging capacity] were assessed at both pre- and post-supplementation times $\left(T_{0}\right.$ and $T_{1}$, respectively). Overall, the internal dose markers remained unchanged at $T_{1}$ as compared to $T_{0}$ in both NAC and placebo groups. Quantifying the biologically effective dose markers, we observed an inhibitory effect of NAC towards the formation of lipophilic-DNA adducts (5.18 \pm 0.73 versus $4.08 \pm 1.03 / 10^{8}$ nucleotides, mean $\pm \mathrm{SE}, \mathrm{P}=0.05)$ as well as of 7,8-dihydro-8-oxo-2'-deoxyguanosine $(8-\mathrm{OH}-\mathrm{dG})$ adducts in BAL cells $\left(3.9 \pm 0.6\right.$ versus $2.3 \pm 0.2 / 10^{5}$ nucleotides, $\left.\mathrm{P}=0.003\right)$. There was no effect of NAC on the formation of lipophilic-DNA adducts in peripheral blood lymphocytes or polycyclic aromatic hydrocarbon-DNA adducts in mouth floor/buccal mucosa cells or 4aminobiphenyl- $\mathrm{Hb}$ adducts. Likewise, quantification of the biological response markers showed an inhibitory effect of NAC on the frequency of micronuclei in mouth floor and in soft palate cells $(1.3 \pm 0.2$ versus $0.9 \pm 0.2, \mathrm{P}=0.001)$, and a stimulating effect of NAC on plasma antioxidants scavenging capacity $(393 \pm 14$ versus $473 \pm 19 \mu \mathrm{M}$ Trolox, $\mathrm{P}=0.1)$ but not on BAL fluid antioxidants scavenging capacity. We conclude that NAC has the potential to impact upon tobacco smoke carcinogenicity in humans as it can modulate certain cancerassociated biomarkers in specific organs.
\end{abstract}

Based on the mantuscript submitted for publication in:

"Cancer Res" 


\section{Chapter Eight}

\section{Chemoprevention trial of $\mathrm{N}$-acetyl-L-cysteine}

\section{INTRODUCTION}

The aminothiol $N$-acetyl-L-cysteine (NAC) has been in clinical practice since the years $60 \mathrm{~s}$ (14). Initially, NAC was introduced as a mucolytic agent for the treatment of respiratory diseases e.g., chronic bronchitis and cystic fibrosis (2,5-7). In the late 70s, NAC was recognized as an antidote for the therapy of acute acetaminophen intoxication $(8,9)$. More recently, NAC has been brought into use for preventing or attenuating pulmonary oxygen toxicity, adult respiratory distress syndrome, influenza-like symptomatology and treating pulmonary obstructive diseases (10-17). The diverse pharmacological applications of NAC are inherent in the multifaceted chemical properties of its constituent, cysteinyl thiol, which enable NAC to act as a nucleophile as well as a scavenger of oxidants (14,18-21). Owing to these nucleophilic and antioxidant properties, NAC has also been proposed as a potential chemopreventive agent $(13,15,21-23)$. So far, NAC has been reported to inhibit a variety of histopathological, cytological, clastogenic, metabolic and molecular alterations induced by various mutagens and/or carcinogens in experimental rodent models $(3,21,24-35)$. These inhibitory effects of NAC have been ascribed to its ability to serve as an analogue of cysteine as well as a precursor of reduced glutathione (GSH), to enhance the activities of glutathione $S$-transferases, glutathione peroxidase, glutathione reductase, NADH- and $\mathrm{NAD}(\mathrm{P}) \mathrm{H}$ - quinone reductase and probably, to promote DNA repair by protecting ADP-ribosyl transferase activity (24,36-48).

In chemoprevention trials, intermediate biomarkers can be used as a valuable means to monitor the chain of events pre- and post-administration of an agent of interest (49). For instance, internal/biologically effective dose markers can reflect the concrete/integrated exposure to carcinogens, or biological response markers can represent the events that give rise to carcinogenesis both before and after the agent is administered. In the present study, we investigated the chemopreventive effects of NAC in humans by applying a multi-biomarker approach quantifying the intermediate markers of exposure and effects induced by cigarette smoking. In a double blind placebo controlled fashion, NAC was supplemented orally for a period of six months to healthy smokers, and internal dose markers [plasma and bronchoalveolar lavage (BAL) fluid cotinine and urine mutagenicity], biologically effective dose markers [smoking-related DNA adducts, oxidative DNA damage and hemoglobin (Hb) adducts] and biological response markers [frequency of micronuclei and antioxidants scavenging capacity] were assessed at both pre- and post-intervention times. The laboratory assays used for quantifying the above-mentioned markers were as follows: [I] radioimmunoassay (RIA) for plasma and BAL fluid cotinine, [II] mutagenicity assay for urine mutagenicity, [III] gas chromatography-mass spectrophotometry (GS-MS) for 4aminobiphenyl (4-ABP)-Hb adducts, [IV] nuclease $\mathrm{Pl}$ enriched ${ }^{32} \mathrm{P}$-postlabeling assay for lipophilic-DNA adducts as well as for 7,8-dihydro-8-oxo-2'-deoxyguanosine (8-OH-dG) adducts in peripheral blood lymphocytes (PBL) and BAL cells, [V] immunhistochemical peroxidase assay for polycyclic aromatic hydrocarbon (PAH) -DNA adducts in mouth floor 
cells (MFC) and buccal mucosa cells (BMC), [VI] micronucleus assay for cytogenetic analyses in MFC and soft palate cells (SPC) and [VII] Trolox equivalent antioxidant capacity (TEAC) assay for plasma and BAL fluid antioxidants scavenging capacity.

\section{MATERIAL AND METHODS}

\section{Study Population}

Forty one healthy volunteers who could not quit smoking were recruited by advertising in the national newspapers. Being briefed for the study protocol, every participant signed an informed consent and filled out a comprehensive questionnaire seeking information on age, sex, occupation, and lifestyle including smoking and drinking behaviors, fresh fruit and vegetable consumption, and vitamin supplementation, medical history of disease and familial history of cancer. The study population was randomly divided into two groups to be treated with NAC $(n=21)$ and placebo $(n=20)$, respectively [Fig. 1]. Detailed characteristics of the study population are listed in Table 1. The study was approved by the Medical Ethical Commission of The Netherlands Cancer Institute.

\section{Study Protocol}

Participants were instructed to strictly maintain their lifestyle and in particular their smoking behavior throughout the intervention period. The randomly assigned NAC or placebo groups were treated orally with two daily doses of NAC $[600 \mathrm{mg}$ each tablet] (Zambon Group, Vicenza, Italy) or placebo for a period of six months in a double blind fashion. Urine, peripheral blood, oral mucosa and BAL of all individuals were sampled at both pre- and postintervention times. To acquire the information on the side effects of NAC/placebo supplementation and to check the compliance with the study protocol, all participants filled out a weekly self-administered questionnaire during the course of the intervention, and also were interviewed at the end of the intervention period. 


\section{Urine}

Twenty four-h urine was collected in polyethylene bottles. Density and $\mathrm{pH}$ were measured and subsequently, $500 \mathrm{ml}$ of the agitated sample was filtered through XAD-2 non-polar resin according to the method of Yamasaki and Ames (50). The resulting concentrate was dissolved in dimethylsulfoxide (DMSO) $[5 \mathrm{ml}]$ and preserved at $-20^{\circ} \mathrm{C}$ until further analysis.

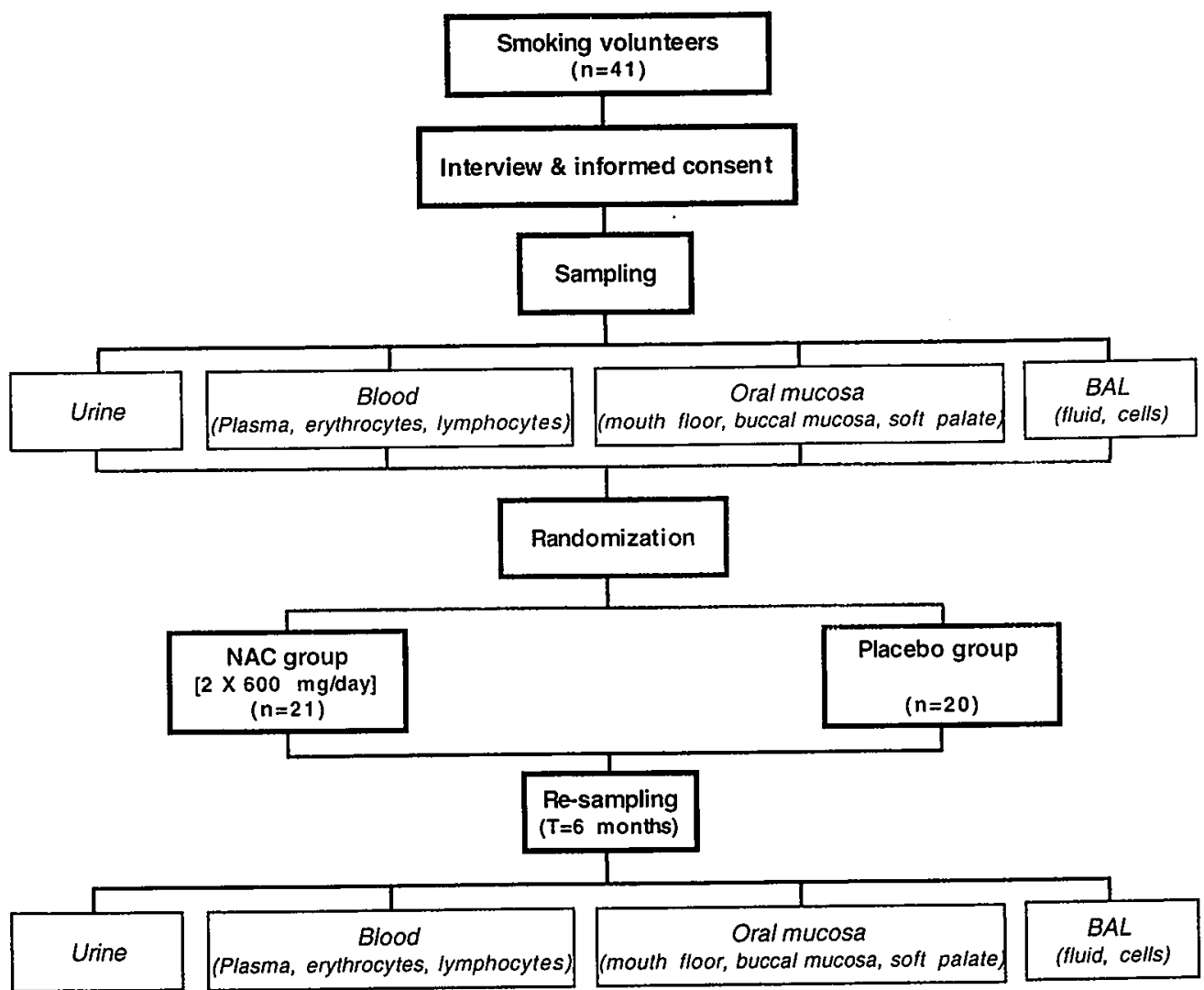

Fig. 1. Flow diagram of the study. 


\section{Peripheral Blood}

Thirty milliliter venous blood were drawn into heparinized Venoject ${ }^{\oplus}$ II tubes (Terumo Europe N.V., Leuven, Belgium). Plasma, erythrocyte and lymphocyte fractions were separated by standard centrifugation procedures $(51,52)$ and subsequently, stored at $-70^{\circ} \mathrm{C}$ until further analysis.

\section{Bronchoalveolar Lavage}

Bronchoalveolar lavage was performed as described earlier (53). Briefly, under local anesthesia, a fiber bronchoscope was introduced into the right middle lobe bronchus and nine aliquots $[20 \mathrm{ml} \mathrm{each}]$ of sterile $0.15 \mathrm{M} \mathrm{NaCl}$ were instilled consecutively with a dwelling time of $3 \mathrm{~min}$. The recovered fluid was collected in plastic tubes placed on ice and after total and differential cell counts, it was pelleted by centrifugation and kept at $-70^{\circ} \mathrm{C}$ until further analysis.

Table 1. Characteristics of the study population

\begin{tabular}{|c|c|c|}
\hline & NAC Group & Placebo Group \\
\hline Number & 21 & 20 \\
\hline Gender (Male/Female) & $6 / 15$ & $8 / 12$ \\
\hline Age & $42 \pm 2.3$ & $44 \pm 1.9$ \\
\hline Cigarettes/Day & $24.8 \pm 2.0$ & $28.5 \pm 3.1$ \\
\hline Tar/Day [mg] & $335.0 \pm 46.1$ & $417.4 \pm 56.9$ \\
\hline Nicotine/Day [mg] & $29.3 \pm 5.0$ & $36.9 \pm 6.1$ \\
\hline Smoking Years & $25 \pm 1.8$ & $27 \pm 1.8$ \\
\hline Pack Years & $31.9 \pm 3.7$ & $39.8 \pm 5.8$ \\
\hline
\end{tabular}

Results are expressed as mean \pm SEM. 


\section{Oral Mucosa}

Mouth floor, buccal mucosa and soft palate cells were harvested by brushing precisely the floor of the mouth, the middle part of the inside of the cheek and the center of the soft palate, respectively, with an interdental brush (Lactona, Almere, the Netherlands). The brushes were stirred in 10-ml Greiner tubes (Greiner Labortechnik, Frickenhausen, Germany) pre-filled with phosphate buffered saline (PBS), $\mathrm{pH} 7.4$, allowing the cells to detach from the brushes. Cell suspensions were centrifuged, resuspended in PBS and filtered through Polyamide Gauze [100 micron mesh opening] (Stokvis \& Smits BV, IJmuiden, the Netherlands). The filtrates were pelleted by centrifugation, resuspended in $\mathrm{PBS}$ and stored at $-70^{\circ} \mathrm{C}$ until further analysis. Prior to cytospinning, the frozen samples were thawed for $20 \mathrm{~min}$ at room temperature. The cell suspensions were cytocentrifuged at $1500 \mathrm{rpm}$ for $5 \mathrm{~min}$ (Shandon Cytospin $^{\circledR 3}$, Cheshire, UK) onto Polysine ${ }^{\mathrm{TM}}$ microslides (E. Merck Nederland B.V., Amsterdam, the Netherlands). The slides were air dried for $1 \mathrm{~h}$ and subsequently, fixed either in acetone at $-20^{\circ} \mathrm{C}$ for $20 \mathrm{~min}$ [prepared for immunohistochemical analysis] or in methanol:acatic acid $\{3: 1\}$ for $10 \mathrm{~min}$ [prepared for micronuclei analysis].

\section{DNA Isolation}

Isolation of DNA was performed as described earlier (54). Briefly, cell pellet was lysed with SET/SDS [ $100 \mathrm{mM} \mathrm{NaCl}, 20 \mathrm{mM}$ EDTA, $50 \mathrm{mM}$ Tris, $0.5 \%$ sodium dodecyl sulfate, $\mathrm{pH} 8.0$ ] at $37^{\circ} \mathrm{C}$, overnight. The resulting suspension was treated with a RNAse mixture [RNAse $A$ $\{0.1 \mathrm{mg} / \mathrm{ml}\}$ and RNAse $\mathrm{T} 1\{1000 \mathrm{U} / \mathrm{ml}\}]$ for $3 \mathrm{~h}$ at $37^{\circ} \mathrm{C}$, followed by a treatment with Proteinase $\mathrm{K}[10 \mathrm{mg} / \mathrm{ml}]$ for $2 \mathrm{~h}$ at $37^{\circ} \mathrm{C}$. DNA was extracted repeatedly with phenol, phenol:chloroform:isoamyl alcohol $\{25: 24: 1\}$ and chloroform:isoamyl alcohol $\{24: 1\}$, precipitated with 2 volumes of $100 \%$ ice-cold ethanol and $1 / 30$ volume of $1 \mathrm{M}$ sodium acetate, $\mathrm{pH} 6.0$, washed with 1 volume of $70 \%$ ethanol and dissolved in $5 \mathrm{mM}$ Tris/1mM EDTA, pH 7.4. Quality and quantity of the DNA were determined spectrophotometrically $\left[A_{230 / 260}: \sim 0.4\right.$, $\left.\mathrm{A}_{260280}:-1.8\right]$ and afterwards, its concentration was adjusted to $1 \mathrm{mg} / \mathrm{ml}$.

\section{Hemoglobin Isolation}

Isolation of $\mathrm{Hb}$ was done as described earlier (52). Briefly, erythrocytes were lysed with icecold deionized water for $20 \mathrm{~min}$ at $0^{\circ} \mathrm{C}$. Debris were removed by centrifugation, the pellet was suspended in PBS, pH 6.0 and the resulting suspension was dialyzed against deionized water for $48 \mathrm{~h}$ at $4^{\circ} \mathrm{C}$ to remove ions and molecules with a molecular weight below 12,000 . $\mathrm{Hb}$ concentration of the dialysate was determined according to the Drabkin's method using a Sigma Kit 525-A (Sigma-Aldrich Chemie BV, Zwijndrecht, the Netherlands) and afterwards, the dialysate was preserved at $-20^{\circ} \mathrm{C}$ until further analysis. 


\section{Cotinine Immunoassay}

Cotinine was determined in plasma and BAL fluid using a standardized RIA according to the published protocols $(55,56)$.

\section{Urine Mutagenicity Assay}

Concentrated urine samples were assayed in a Salmonella typhimurium YG1024 test system in the presence of S9 mix [10\% liver S12 fractions from Aroclor-pretreated Sprague-Dawely rats] at three doses $[25,50$ and $100 \mu \mathrm{l} /$ plate $]$ in triplicate, with and without $\beta$-glucuronidase [1000 U/plate] (57). For each sample, the average mutagenic response was taken from all experimental settings. The results were expressed as the number of induced revertants [adjusted for total volume of urine excreted in $24 \mathrm{~h}$ ].

\section{Gas Chromatography-Mass Spectrophotometry}

Gas chromatography-mass spectrophotometry was performed as described earlier (58). Briefly, dialysate hemoglobin [20 ml] was spiked with 4'-fluoro-4-ABP (4'-F-ABP) [1 ng] and subsequently, incubated with $10 \mathrm{~N} \mathrm{NaOH}$ at room temperature for $2.5 \mathrm{~h}$. The resultant was extracted twice with hexane $[20 \mathrm{ml}]$, followed by the addition of ethanol [50 $\mu \mathrm{l}]$ and centrifugation. The hexane was dried over anhydrous $\mathrm{Na}_{2} \mathrm{SO}_{4}^{-} \mathrm{MgSO}_{4}$, collected in deactivated glass vessels in aliquots of $2 \mathrm{ml}$, and 4-ABP and $4^{\prime}$-F-ABP were derivatized by incubation with trithylamine:hexane $\{1: 5\}[5 \mu l]$ and pentafluoropropionic anhydride $[3 \mu \mathrm{l}]$ for $2 \mathrm{~h}$ at room temperature. The hexane was evaporated and the residue containing 4-ABP and 4'-FABP was dissolved in dichloromethane $[20 \mu \mathrm{l}]$. The solution $[0.5 \mu \mathrm{l}]$ was introduced into the GC-MS and 4-ABP and 4'-F-ABP were quantified applying the negative ion chemical ionization mass spectrometry under the selected ion-monitoring conditions at 295 and 313 $\mathrm{m} / \mathrm{z}$, respectively. The GC-MS setting consisted of a HP 5890 Series II capillary GC (Hewlett Packard, Portland, OR) coupled with a Jeol SX 102A double-focusing MS of reversed geometry (Jeol, Tokyo, Japan). The GC was operational at an injecting temperature of $260^{\circ} \mathrm{C}$ using a 25-m fused silica SGE BPX 35 column (SGE, Austin, TX) [inside diameter, $0.32 \mathrm{~mm}$; film thickness, $0.25 \mu \mathrm{m}$ ]. The column temperature was $60^{\circ} \mathrm{C}$ for $2 \mathrm{~min}$ and subsequently, rose at a rate of $30^{\circ} \mathrm{C}$ per min up to $320^{\circ} \mathrm{C}$. Helium was used as a carrier gas at a flow rate of $1 \mathrm{ml}$ per minute. The MS was operational at an ion source temperature of $230^{\circ} \mathrm{C}$, an ionizing energy of $200 \mathrm{eV}$ and an accelerating potential of $10 \mathrm{KV}$. Methane was utilized as the reaction gas. Quantification was done by using standard $\mathrm{Hb}$ dialysates with known concentrations of 4ABP [lower detection limit, $1 \mathrm{pg} 4-\mathrm{ABP} / \mathrm{g} \mathrm{Hb}$ ]. The intra- and inter-assay variations were 10.4 $\pm 5.2 \%(n=4)$ and $22.0 \pm 3.5 \%(n=5)$, respectively. 


\section{${ }^{32}$ P-postlabeling Assay for Lipophilic-DNA Adducts}

The ${ }^{32} \mathrm{P}$-postlabeling assay for lipophilic-DNA adducts was performed as described earlier (54). Briefly, DNA [5 $\mu \mathrm{g}$ ] was digested into deoxyribonucleoside 3'-monophosphates by an incubation with micrococcal endonuclease [0.5 U] and spleen phosphodiesterase [3.3 $\mu \mathrm{g}$ ] for $3 \mathrm{~h}$ at $37^{\circ} \mathrm{C}$. Half of the digest was treated with nuclease P1 [7.3 $\mu \mathrm{g}$ ] for $40 \mathrm{~min}$ at $37^{\circ} \mathrm{C}$ and the reaction was terminated by adding $0.5 \mathrm{M}$ Tris. Labeling was performed using AT- $\gamma^{32} \mathrm{P}$ [50 $\mathrm{Ci}$ ] in the presence of $\mathrm{T} 4$-polynucleotide kinase [5.8 U] for $30 \mathrm{~min}$ at $37^{\circ} \mathrm{C}$ and subsequently, thin layer chromatography was done on polyethyleneimine (PEI) -cellulose sheets (Macherey Nagel, Düren, Germany) with the following solvent systems: $D_{1}, 1 \mathrm{M}$ $\mathrm{NaH}_{2} \mathrm{PO}_{4}, \mathrm{pH} 6.5 ; \mathrm{D}_{2}, 8.5 \mathrm{M}$ Urea, 5.3 $\mathrm{M}$ Lithium formate, $\mathrm{pH} 3.5 ; \mathrm{D}_{3}, 1.2 \mathrm{M}$ Lithium chloride, $0.5 \mathrm{M}$ Tris, 8.5 Urea, $\mathrm{pH} 8.0 ; \mathrm{D}_{4}, 1.7 \mathrm{M} \mathrm{NaH}_{2} \mathrm{PO}_{4}$, $\mathrm{pH}$ 6.0. Detailed information on the efficiency of nuclease P1 digestion and ATP excess is available in ref. (54). To quantify the nucleotides, the remaining DNA digest was labeled with AT $-\gamma_{-}{ }^{32} \mathrm{P}[15 \mu \mathrm{Ci}]$ in the presence of T4-polynucleotide kinase under the same conditions as mentioned above. It was then chromatographed one-dimensionally on PEI-cellulose sheet (Merck, Darmstadt, Germany) using a solvent system of $0.12 \mathrm{M} \mathrm{NaH}_{2} \mathrm{PO}_{4}, \mathrm{pH} 6.8$. For standardization, control samples of $\left[{ }^{3} \mathrm{H}\right] \mathrm{BPDE}$ modified DNA with known modification levels $\left[1\right.$ adduct per $10^{7}$ and $10^{8}$ unmodified nucleotides] were run in all experiments. Quantification was done using a phosphor imager (Molecular Dynamics ${ }^{\mathrm{TM}}$, Sunnyvale, CA) with a lower detection limit of 1 adduct per $10^{9}$ nucleotides.

\section{${ }^{32} P$-postlabeling Assay for 8-OH-dG Adducts}

The ${ }^{32} \mathrm{P}$-postlabeling assay for $8-\mathrm{OH}-\mathrm{dG}$ adducts was performed as described earlier (59). In order to avoid artifacts, which may result from radiation-induced oxidation of guanine, a selective hydrolysis of $\mathrm{dGp}$ was achieved by treating depolimerized DNA with $90 \%$ trifluoroacetic acid before the ${ }^{32} \mathrm{P}$ postlabeling reaction (60). Briefly, DNA [6 $\mu \mathrm{g}$ ] was digested with micrococcal endonuclease [0.5 U] and spleen phosphodiesterase [6.8 $\mu \mathrm{g}$ ] [incubation, 3.5 $\mathrm{h}, 37^{\circ} \mathrm{C}$ ] and then, with nuclease P1 [2.37 U] [incubation, $40 \mathrm{~min}, 37^{\circ} \mathrm{C}$ ]. Subsequently, labeling was done by AT- $\gamma{ }^{32} \mathrm{P}[80 \mu \mathrm{Ci}]$ in the presence of $\mathrm{T} 4$-polynucleotide kinase $[8 \mathrm{U}]$ for $40 \mathrm{~min}$ at room temperature. Afterwards, thin layer chromatography was carried out on PEIcellulose sheets with the following solvent systems: $D_{1}, 1.5$ formic acid, $\mathrm{pH} 1.5 ; \mathrm{D}_{2}, 0.6 \mathrm{M}$ ammonium formate, $\mathrm{pH}$ 6.0. Autoradiography was performed by using a ${ }^{32} \mathrm{P}$ InstantImager Electronic Autoradiographic System equipped with InstantQuant software (model A2024, Packard, Meriden, CT). The results were expressed as $8-\mathrm{OH}-\mathrm{dG} / 10^{5}$ nucleotides. 


\section{Immunohistochemical Peroxidase Assay}

Immunohistochemistry of PAH-DNA adducts was performed as described earlier (61). Briefly, after rehydration and antigen retrieval, the slides were treated with RNase A [100 $\mu \mathrm{g} / \mathrm{ml}]$ for $1 \mathrm{~h}$ at $37^{\circ} \mathrm{C}$ and then, incubated with proteinase $\mathrm{K}[10 \mu \mathrm{g} / \mathrm{ml}]$ for $10 \mathrm{~min}$ at room temperature. Being immersed in $4 \mathrm{~N} \mathrm{HCl}$ for $7 \mathrm{~min}$ and afterwards, in $50 \mathrm{mM}$ Tris base for 5 min, the slides were pre-incubated with $2 \%$ Bovine Albumin for $45 \mathrm{~min}$ at $37^{\circ} \mathrm{C}$ and subsequently, incubated overnight at $4^{\circ} \mathrm{C}$ with the primary antibody $5 \mathrm{D} 11$ [1:150 in $2 \%$ Bovine Albumin]. This antibody recognizes benzo[a]pyrene ( $\mathrm{B}[\mathrm{a}] \mathrm{P})$ diolepoxide- and some structurally related PAH diolepoxide-DNA adducts $(62,63)$. The following day, the slides were incubated with biotinylated Anti-Mouse $\operatorname{IgG}[\mathrm{H}+\mathrm{L}]$ (Brunschwig, Amsterdam, the Netherlands) [1:200 in $2 \%$ Bovine Albumin] for $30 \mathrm{~min}$ at $37^{\circ} \mathrm{C}$, treated with $0.3 \% \mathrm{H}_{2} \mathrm{O}_{2}$ in methanol for $30 \mathrm{~min}$ and then, stained immunoperoxidically using a VECTASTAIN ${ }^{\oplus} \mathrm{ABC}$ system [Avidin $\mathrm{DH}+$ biotinylated horse-radish peroxidase $\mathrm{H}$ ] (Brunschwig). The slides were dipped into $1 \%$ Triton $X-100$ and thereafter, staining was visualized with a 3, 3'diaminobenzidine (DAB) substrate kit $[D A B+$ nickel chloride] (Brunschwig). The slides were rinsed with tap water, dehydrated with graded ethanol and finally, cleared with xylene. A rinse with $\mathrm{PBS}, \mathrm{pH} 7.4$, followed all steps except the one after the pre-incubation with $2 \%$ Bovine Albumin.

Quantification was done using an Image Processing and Analysis System [Quantimet 500 , Leica, Cambridge, UK) by measuring the relative nucleic density of staining (corrected for cytoplasmic and extracellular density of staining as background] in 200 morphologically well-defined cells per slide [range, $0.00-2.40$ ]. Detailed information on the quantification procedure and the examination of specificity and sensitivity of immunoperoxidase staining is available in ref. (61).

\section{Micronucleus Assay}

The micronucleus assay was performed on cytospin slides of MFC and SPC stained according to Feulgen reaction. Briefly, the slides were treated to mild acid hydrolysis for $1 \mathrm{~h}$ in a $5 \mathrm{~N}$ solution of $\mathrm{HCl}$. After several rinses in distilled water, the slides were immersed in filtered Schiff's reagent (Sigma Chemical Co., St. Louis, MO) for $30 \mathrm{~min}$, washed in distilled water and left in running tap water for $5 \mathrm{~min}$ in order to intensify the staining of the Schiff's reagent. Finally, the slides were blotted dry and mounted in Eukitt (BDH Chemicals Ltd., Poole, UK). The frequency of micronuclei (\%o) was evaluated by scoring 1,000 cells per slide at a $\times 1000$ magnification. The micronuclei were identified according to standardized criteria $(64,65)$. 


\section{Trolox Equivalent Antioxidant Capacity Assay}

TEAC assay was performed as described earlier (66). Briefly, after generation of the longlived radical anion of ABTS in the presence of a thermolabile azo compound, 2,2'-azobis-2amidinopropane (ABAP), plasma was added and subsequently, absorbance was monitored at $734 \mathrm{~nm}$ over a period of $6 \mathrm{~min}$. The decrease in the absorbance after addition of the plasma was plotted on a calibration curve established by application of known concentrations of Trolox, an analogue of vitamin E, as standard. Results were expressed as $\mu \mathrm{M}$ Trolox.

\section{Statistical Analysis}

Results were expressed as mean \pm standard error throughout the text. Using the MannWhitney $U$-test, all variables in the NAC group at pre- or post-intervention times were compared with their respectives in the placebo group. Utilizing the Wilcoxon signed rank test, all variables in the NAC or placebo groups at pre-intervention time were compared with their respectives at post-intervention time. The Spearman rank correlation analysis was performed to explore the relationships between different variables. Statistical significance was considered at $\mathrm{P}<0.05$.

\section{RESULTS}

Although one individual in the NAC group experienced minor side effects, all 41 participants well-tolerated the NAC/placebo treatment throughout and completed the study. From the beginning, nine individuals refused to undergo bronchoscopic procedures for BAL, mainly due to the invasiveness of this method. Of 32 volunteers who initially underwent the BAL, another 7 persons withdrew from the second sampling. Due to further technical failures, some biomarkers could not be quantified at both pre- and post-intervention times, $T_{0}$ and $T_{1}$, respectively, for all individuals. Thus, only paired data are presented and analyzed throughout. Table 2 summarizes the paired measurements of all biomarkers at $T_{0}$ and $T_{1}$ in this study.

\section{Plasma and Bronchoalveolar Lavage Fluid Cotinine}

There was no significant difference in plasma cotinine levels between NAC $(n=21)$ and placebo $(n=20)$ groups at $T_{0}(441 \pm 45$ versus $495 \pm 41 \mu \mathrm{M} / \mathrm{L}, \mathrm{P}=0.4)$ or at $T_{1}(467 \pm 56$ versus $469 \pm 39 \mu \mathrm{M} / \mathrm{L}, \mathrm{P}=0.7)$. Neither in NAC group nor in placebo group, was there any significant change in plasma cotinine levels at $T_{\text {, as compared to }} \mathrm{T}_{0}$ (NAC, $467 \pm 56$ versus $445 \pm 57 \mu \mathrm{M} / \mathrm{L}, \mathrm{P}=0.3(\mathrm{n}=15)$; placebo, $469 \pm 39$ versus $510 \pm 47 \mu \mathrm{M} / \mathrm{L}, \mathrm{P}=0.2(\mathrm{n}=16)$ ). In both NAC and placebo groups, plasma cotinine levels at $T_{1}$ were significantly correlated 
with those at $T_{0}(r=0.7, P=0.009$ and $r=0.7, P=0.005$, respectively) [Fig. 2]. Likewise, no significant difference was observed in BAL fluid cotinine levels between NAC $(n=14)$ and placebo $(n=18)$ groups at $T_{0}(1826 \pm 266$ versus $2196 \pm 412 \mu \mathrm{M} / \mathrm{L}, \mathrm{P}=0.8)$ or at $T_{1}(3678 \pm$ 1793 versus $1794 \pm 291 \mu \mathrm{M} / \mathrm{L}, \mathrm{P}=0.5$ ). While in the NAC group BAL fluid cotinine levels increased non-significantly at $T_{1}$ as compared to $T_{0}(3678 \pm 1793$ versus $1788 \pm 315 \mu \mathrm{M} / \mathrm{L}$, $P=0.5(n=11))$, in the placebo group there was a significant decrease in BAL fluid cotinine levels at $T_{1}$ as compared to $T_{0}(1794 \pm 291$ versus $2527 \pm 480 \mu \mathrm{M} / L, P=0.05(n=14))$.

Table 2. Summary (paired) data of the quantified biomarkers in NAC and placebo groups at pre- and postintervention times

\begin{tabular}{|c|c|c|c|c|}
\hline & \multicolumn{2}{|c|}{$\begin{array}{l}\text { NAC Group } \\
\text { (Mean } \pm \text { SE) }\end{array}$} & \multicolumn{2}{|c|}{$\begin{array}{l}\text { Placebo Group } \\
\text { (Mean } \pm \text { SE) }\end{array}$} \\
\hline & $\mathrm{T}_{0}$ & $\mathbf{T}_{1}$ & $\mathbf{T}_{\mathbf{0}}$ & $T_{1}$ \\
\hline Cotinine (Plasma) $[\mu \mathrm{M} / \mathrm{L}]$ & $445 \pm 57^{\prime}$ & $467 \pm 56$ & $510 \pm 47$ & $469 \pm 39$ \\
\hline Cotinine (BAL fluid) $[\mu \mathrm{M} / \mathrm{L}]$ & $1788 \pm 315$ & $3678 \pm 1793$ & $2527 \pm 480$ & $1794 \pm 291^{2}$ \\
\hline Urine mutagenicity [x 1000 Revertants] & $154 \pm 36$ & $133 \pm 18$ & $153 \pm 24$ & $121 \pm 19$ \\
\hline 4-ABP-Hb adducts [pg/g Hb] & $0.21 \pm 0.02$ & $0.20 \pm 0.02$ & $0.23 \pm 0.02$ & $0.26 \pm 0.02$ \\
\hline $\begin{array}{l}\text { Lipophilic-DNA adducts (PBL) } \\
{\left[/ 10^{8} \text { nucleotides }\right]}\end{array}$ & $1.46 \pm 0.1$ & $2.50 \pm 0.5$ & $1.46 \pm 0.2$ & $2.52 \pm 0.3^{3}$ \\
\hline $\begin{array}{l}\text { Lipophilic-DNA adducts (BAL cells) } \\
\text { [/10 nucleotides] }\end{array}$ & $6.01 \pm 0.9$ & $4.25 \pm 0.8^{4}$ & $6.03 \pm 0.7$ & $5.9 \pm 0.7$ \\
\hline $\begin{array}{l}\text { 8-OH-dG adducts (BAL cells) } \\
{\left[/ 10^{5} \text { nucleotides] }\right.}\end{array}$ & $4.9 \pm 0.7$ & $1.8 \pm 0.3^{5.6}$ & $4.8 \pm 0.5$ & $3.2 \pm 0.8$ \\
\hline $\begin{array}{l}\text { PAH-DNA adducts (Mouth floor cells) } \\
\text { [Nucleic stain density] }\end{array}$ & $0.04 \pm 0.01$ & $0.06 \pm 0.01$ & $0.05 \pm 0.01$ & $0.05 \pm 0.01$ \\
\hline $\begin{array}{l}\text { PAH-DNA adducts (Buccal mucosa cells) } \\
\text { [Nucleic stain density] }\end{array}$ & $0.06 \pm 0.01$ & $0.05 \pm 0.01$ & $0.06 \pm 0.01$ & $0.07 \pm 0.01$ \\
\hline Micronuclei (Mouth floor cells) [\%o] & $1.3 \pm 0.3$ & $0.9 \pm 0.3^{7}$ & $1.2 \pm 0.3$ & $1.0 \pm 0.2$ \\
\hline Micronuclei (Soft palate cclls) [\%o] & $1.3 \pm 0.2$ & $0.9 \pm 0.2$ & $1.4 \pm 0.2$ & $1.5 \pm 0.2$ \\
\hline TEAC (Plasma) $[\mu \mathrm{M}]$ & $394 \pm 16$ & $449 \pm 20$ & $387 \pm 11$ & $450 \pm 12^{x}$ \\
\hline TEAC (BAL fluid) $[\mu \mathrm{M}]$ & $2043 \pm 254$ & $1806 \pm 271$ & $1703 \pm 203$ & $1777 \pm 272$ \\
\hline
\end{tabular}

'Number of the individuals per group $(n)$ is indicated in the text. 'Statistically significant compared to placebo group at $\mathrm{T}_{11}, \mathrm{P}=0.05$. ${ }^{3}$ Statistically significant compared to placebo group at $\mathrm{T}_{0} ; \mathrm{P}=0.01$. ${ }^{4}$ Statistically significant compared to NAC group at $T_{0} ; P=0.05$. ${ }^{5}$ Statistically significant compared to placebo group at $T_{1}$; $\mathrm{P}=0.03$. "Statistically significant compared to NAC group at $\mathrm{T}_{61} ; \mathrm{P}=0.003$. 'Statistically significant compared to NAC group at $\mathrm{T}_{i} ; \mathrm{P}=0.05$. "Statistically significant compared to placebo group at $\mathrm{T}_{i j} ; \mathrm{P}=0.008$. 
Only in the placebo group was there a significant correlation between BAL fluid cotinine levels at $T_{1}$ and those at $T_{0}(r=0.6, P=0.05)$. In both NAC and placebo groups BAL fluid cotinine levels were interrelated to plasma cotinine levels at $T_{0}(r=0.5, P=0.08$ and $r=0.4, P=0.07$, respectively) as well as at $T_{1}(r=0.7, P=0.02$ and $r=0.5, P=0.08$, respectively). Overall, plasma/BAL fluid cotinine data did not correspond with the data derived from the questionnaire on smoking status [number of cigarettes smoked per day, amount of tar/nicotine consumed per day].
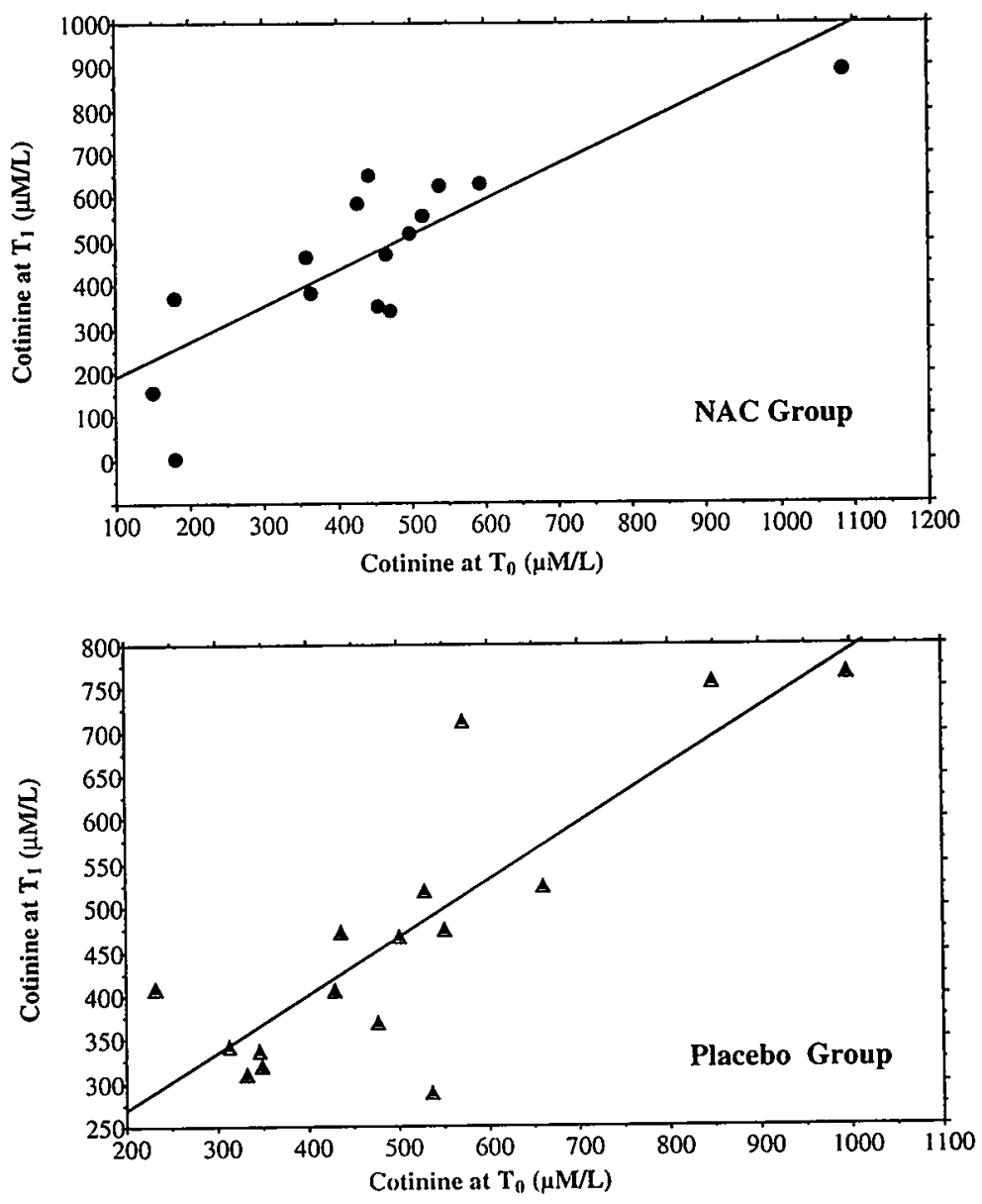

Fig. 2. Correlation between plasma cotinine levels in the NAC $(r=0.7, P=0.009)$ and placebo $(r=0.7, P=$ 0.005 ) groups at time $0\left(T_{0}\right)$ and after 6 months $\left(T_{1}\right)$. 


\section{Urine Mutagenicity}

There was no significant difference in urine mutagenicity levels between NAC $(n=6)$ and placebo $(n=11)$ groups at $T_{0}\left(154 \pm 36\right.$ versus $153 \pm 24 \times 10^{3}$ revertants $)$ or at $T_{1}(133 \pm 18$ versus $121 \pm 19 \times 10^{3}$ revertants, $P=0.5$ ). Also, there was not any significant change in urine mutagenicity levels at $T_{1}$ as compared to $T_{0}$ either in the NAC group $(133 \pm 18$ versus $154 \pm$ $36 \times 10^{3}$ revertants, $\left.P=0.8(n=6)\right)$ or in the placebo group $\left(121 \pm 19\right.$ versus $153 \pm 24 \times 10^{3}$ revertants, $P=0.2(n=11)$ ). Furthermore, there was no correlation between urine mutagenicity levels at $T_{1}$ and those at $T_{0}$ in NAC or placebo groups. Urine mutagenicity data in placebo group at $T_{1}$ were correlated with the respective plasma cotinine data $(r=0.6, P=0.05)$. No correlation was found between urine mutagenicity and the questionnaire derived smoking indices.

\section{4-ABP-Hemoglobin Adducts}

There was no significant difference in 4-ABP-Hb adduct levels between NAC $(n=21)$ and placebo $(\mathrm{n}=20)$ groups at $\mathrm{T}_{0}(0.20 \pm 0.02$ versus $0.23 \pm 0.02 \mathrm{pg} / \mathrm{g} \mathrm{Hb}, \mathrm{P}=0.2)$. However, at $T_{1}$ the difference was more appreciable $(0.20 \pm 0.02$ versus $0.26 \pm 0.02 \mathrm{pg} / \mathrm{g} \mathrm{Hb}, \mathrm{P}=0.08)$. Apparently, this difference was due to the non-significant increase in placebo group 4-ABP$\mathrm{Hb}$ adduct levels at $T_{1}$ as compared to $T_{0}(0.26 \pm 0.02$ versus $0.23 \pm 0.02 \mathrm{pg} / \mathrm{g} \mathrm{Hb}, P=0.1$ $(n=16)$ ). In both NAC and placebo groups, 4-ABP-Hb adduct levels at $T_{1}$ were significantly correlated with those at $\mathrm{T}_{0}(r=0.7, \mathrm{P}=0.005$ and $\mathrm{r}=0.5, \mathrm{P}=0.05$, respectively). In the placebo group, 4-ABP-Hb adduct levels at $T_{0}$ were correlated with the respective plasma cotinine levels $(r=0.5, P=0.05)$. No correlation was found between $4-\mathrm{ABP}-\mathrm{Hb}$ adduct data and urine mutagenicity data, or the questionnaire derived smoking status data.

\section{Lipophilic-DNA Adducts in Peripheral Blood Lymphocytes and Bronchoalveolar Lavage Cells}

Briefly, cell yields of the BAL samples at $T_{0}$ and $T_{\text {, were }} 10.1 \pm 1.2$ versus $10.9 \pm 1.4 \times 10^{7}$, $\mathrm{P}=0.9$ in NAC group and $9.7 \pm 0.9$ versus $6.8 \pm 1.1 \times 10^{7}, \mathrm{P}=0.02$ in placebo group. Overall, BAL consisted of pulmonary alveolar macrophages (70 - 90\%) and minor number of bronchoepithelial cells and lymphocytes.

Qualitatively, there was a typical smoking-associated diagonal radioactive zone (DRZ) in adduct maps of most individuals irrespective of NAC/placebo treatment; no separate adduct spots could be detected (53). Quantitation of the DRZ showed no significant difference in PBL lipophilic-DNA adduct levels between NAC $(n=21)$ and placebo $(n=20)$ groups at $T_{0}$ $\left(1.54 \pm 1.1\right.$ versus $\left.1.52 \pm 0.14 / 10^{8} \mathrm{nt}, \mathrm{P}=0.8\right)$ or at $\mathrm{T}_{1}\left(2.50 \pm 0.46\right.$ versus $2.52 \pm 0.31 / 10^{8} \mathrm{nt}$, $\mathrm{P}=0.6$ ). In both NAC and placebo groups, $\mathrm{PBL}$ lipophilic-DNA adduct levels were increased at $T_{1}$ as compared to $T_{0}$ (NAC, $2.50 \pm 0.5$ versus $1.46 \pm 0.1 / 10^{8} n t, P=0.06(n=15)$; placebo, 
$2.52 \pm 0.3$ versus $1.46 \pm 0.2 / 10^{8} \mathrm{nt}, \mathrm{P}=0.01(\mathrm{n}=16)$ ). No correlation was found between PBL lipophilic-DNA adduct levels at $T_{1}$ and the respective levels at $T_{0}$ either in NAC or in placebo group.

There was no significant difference in BAL cells lipophilic-DNA adduct levels between NAC $(n=12)$ and placebo $(n=16)$ groups at $T_{0}\left(5.74 \pm 0.73\right.$ versus $6.07 \pm 0.60 / 10^{8} n t, P=$ $0.7)$ or at $\mathrm{T}_{1}\left(4.94 \pm 1.03\right.$ versus $\left.5.61 \pm 0.60 / 10^{8} \mathrm{nt}, \mathrm{P}=0.4\right)$. In the NAC group there was a significant decrease in BAL cells lipophilic-DNA adduct levels at $T_{1}$ as compared to $T_{0}(4.25$ \pm 0.8 versus $6.01 \pm 0.9 / 10^{8} \mathrm{nt}, \mathrm{P}=0.05(\mathrm{n}=10)$ ), whereas in the placebo group the decrease was not significant $\left(5.90 \pm 0.7\right.$ versus $6.03 \pm 0.7 / 10^{8} \mathrm{nt}, \mathrm{P}=0.7(\mathrm{n}=10)$ ). Interestingly, the decrease in BAL cells lipophilic-DNA adduct levels in the NAC group was inversely correlated to the number of cigarettes smoked per day $(r=0.7, P=0.04)$ [Fig. 3]. Only in the placebo group was there a significant correlation between BAL cells lipophilic-DNA adduct levels at $\mathrm{T}_{1}$ and those at $\mathrm{T}_{0}(\mathrm{r}=0.8, \mathrm{P}=0.02)$. Neither in NAC nor in placebo groups, BAL cells and PBL lipophilic-DNA adduct levels were interrelated to each other. In the NAC group

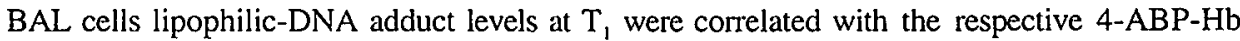
adduct levels $(\mathrm{r}=0.8, \mathrm{P}=0.01)$. No correlation was observed between $\mathrm{BAL}$ cells $/ \mathrm{PBL}$ lipophilic-DNA adduct data and the data on urine mutagenicity or plasma/BAL fluid cotinine or self-reported smoking status.

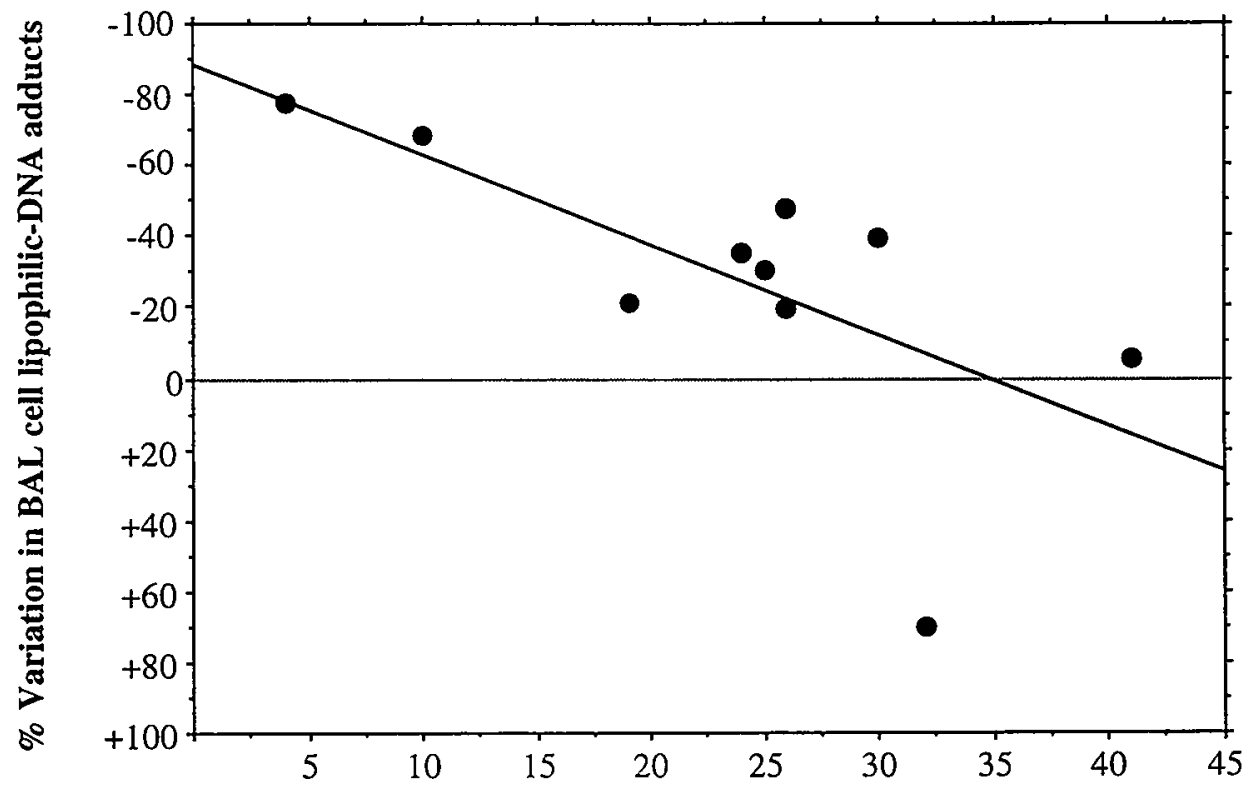

Cigarettes / day

Fig. 3. Exposure dependency of NAC in modulating BAL cells lipophilic-DNA adducts. 


\section{8-OH-dG Adducts in Bronchoalveolar Lavage Cells}

There was no significant difference in BAL cells 8-OH-dG adduct levels between NAC $(n=5)$ and placebo $(n=4)$ groups at $T_{0}\left(4.2 \pm 0.6\right.$ versus $\left.4.5 \pm 0.5 / 10^{5} n t, P=0.6\right)$, however, at $T_{1}$ the difference was statistically significant $\left(2.2 \pm 0.2\right.$ versus $\left.3.2 \pm 0.4 / 10^{5} \mathrm{nt}, \mathrm{P}=0.03\right)$. Although in both NAC and placebo groups BAL cells 8-OH-dG adduct levels were decreased at $T_{1}$ as compared to $\mathrm{T}_{0}$, the decrease was only significant in the NAC group (NAC, $1.8 \pm 0.3$ versus $4.9 \pm 0.7 / 10^{5} \mathrm{nt}, \mathrm{P}=0.003(\mathrm{n}=3)$; placebo, $3.2 \pm 0.8$ versus $4.8 \pm 0.5 / 10^{5} \mathrm{nt}, \mathrm{P}=0.6(\mathrm{n}=3)$ ). Neither in the NAC group nor in the placebo group was there any correlation between BAL cells $8-\mathrm{OH}-\mathrm{dG}$ adduct levels at $\mathrm{T}_{1}$ and those at $\mathrm{T}_{0}$. The data on BAL cells $8-\mathrm{OH}-\mathrm{dG}$ adducts did not correspond with the respective data on PBL/BAL cells lipophilic-DNA adducts or 4$\mathrm{ABP}-\mathrm{Hb}$-adducts or urine mutagenicity or plasma/BAL fluid cotinine or smoking status.

\section{PAH-DNA Adducts in Mouth Floor and Buccal Mucosa Cells}

There was no significant difference in MFC PAH-DNA adduct levels between NAC $(n=12)$ and placebo $(n=14)$ groups at $T_{0}(0.04 \pm 0.01$ versus $0.05 \pm 0.01, P=0.5)$ or at $T_{1}(0.06 \pm$ 0.01 versus $0.05 \pm 0.01, \mathrm{P}=0.2$ ). At $\mathrm{T}_{1}$ as compared to $\mathrm{T}_{0}, \mathrm{MFC} \mathrm{PAH}-\mathrm{DNA}$ adduct levels were increased in the NAC group $(0.06 \pm 0.01$ versus $0.04 \pm 0.01, P=0.08(n=12))$, whereas in the placebo group the level of adducts remained unchanged $(0.05 \pm 0.01$ versus $0.05 \pm$ $0.01(n=14))$. Neither in NAC nor in placebo groups, was there any correlation between MFC PAH-DNA adduct levels at $T_{1}$ and those at $T_{0}$. Also, there was not any correlation between MFC PAH-DNA adduct data and the respective data on BAL 8-OH-dG adducts or PBL/BAL cells lipophilic-DNA adducts or 4-ABP-Hb adducts or urine mutagenicity or plasma/BAL fluid cotinine. Nevertheless, in the placebo group at $T_{0}$ MFC PAH-DNA adduct levels did correspond with the questionnaire derived smoking indices (tar/day, $r=0.6, P=0.02$; nicotine/day, $\mathrm{r}=0.7, \mathrm{P}=0.007$ ).

There was no significant difference in BMC PAH-DNA adduct levels between NAC ( $\mathrm{n}=$ 9) and placebo $(n=14)$ groups at $T_{0}(0.06 \pm 0.01$ versus $0.06 \pm 0.01)$ or at $T_{1}(0.08 \pm 0.02$ versus $0.07 \pm 0.01, P=0.8$ ). Nor was there any difference in $B M C$ PAH-DNA adducts at $T_{1}$ as compared to $T_{0}$ in the NAC group $(0.05 \pm 0.01$ versus $0.06 \pm 0.01, P=0.3(n=9))$ or in the placebo group $(0.07 \pm 0.01$ versus $0.06 \pm 0.01, P=0.4(n=13))$. Neither in NAC nor in placebo groups, was there any correlation between BMC PAH-DNA adduct levels at $T_{1}$ and those at $\mathrm{T}_{0}$. Also, BMC and MFC PAH-DNA adduct levels were not interrelated to each other. There was not any correlation between BMC PAH-DNA adduct data and the respective data on BAL cells 8-OH-dG adducts or PBL/BAL cells lipophilic-DNA adducts or 4-ABP-Hb adducts or urine mutagenicity or plasma/BAL fluid cotinine. Nonetheless, in the placebo group at $T_{1}, B M C P A H-D N A$ adducts corresponded with the questionnaire derived smoking indices (tar/day, $\mathrm{r}=0.7, \mathrm{P}=0.01$; nicotine/day, $\mathrm{r}=0.7, \mathrm{P}=0.01$ ). 


\section{Micronuclei Frequency in Mouth Floor and Soft Palate Cells}

There was no significant difference in MFC micronuclei frequency between NAC $(n=15)$ and placebo $(n=15)$ groups at $T_{0}(1.3 \pm 0.3$ versus $1.2 \pm 0.3, P=0.8)$ or at $T_{1}(0.9 \pm 0.3$ versus $1.0 \pm 0.2, \mathrm{P}=0.5)$. Although in both NAC and placebo groups MFC micronuclei frequency decreased at $T_{1}$ as compared to $T_{0}$, such decrease was significant only in the NAC group (0.9 \pm 0.3 versus $1.3 \pm 0.3, P=0.05(n=15)$ ). Furthermore, there was a significant correlation between MFC micronuclei frequency at $T_{1}$ and those at $T_{0}$ in both NAC $(r=0.8, P=0.004)$ and placebo groups ( $r=0.6, P=0.02$ ). MFC micronuclei formation data did not correlate with the respective data on MFC/BMC PAH-DNA adducts or BAL cells 8-OH-dG adducts or PBL/BAL cells lipophilic-DNA adducts or 4-ABP-Hb adducts or urine mutagenicity or plasma/BAL fluid cotinine or smoking status.

There was no significant difference in SPC micronuclei frequency between NAC ( $n=$ 15) and placebo $(n=15)$ groups at $T_{0}(1.3 \pm 0.2$ versus $1.4 \pm 0.2, P=0.9)$ or at $T_{1}(0.9 \pm 0.2$ versus $1.5 \pm 0.2, \mathrm{P}=0.08$ ). Nor was there any significant difference in SPC micronuclei frequency at $T_{1}$ as compared to $T_{0}$ either in the NAC group, in spite of an appreciable decrease $(0.9 \pm 0.2$ versus $1.3 \pm 0.2, \mathrm{P}=0.1(\mathrm{n}=15))$ or in the placebo group $(1.5 \pm 0.2$ versus $1.4 \pm$ $0.2, P=0.6(n=15))$. SPC micronuclei formation data did not correlate with the data on MFC/BMC PAH-DNA adducts, or BAL cells $8-\mathrm{OH}-\mathrm{dG}$ adducts, or PBL/BAL cells lipophilic-DNA adducts or 4-ABP-Hb adducts or urine mutagenicity or plasma/BAL fluid cotinine or the smoking status. By combining the data from the two buccal sites, the decrease of micronucleus frequency at $T_{1}$ as compared $T_{0}$ was only significant in the NAC group (0.9 \pm 0.2 versus $1.3 \pm 0.2, P=0.01$ ).

\section{Antioxidants Scavenging Capacity of Plasma and Bronchoalveolar Lavage Fluid}

There was no significant difference in plasma antioxidants scavenging capacity between NAC $(n=20)$ and placebo groups at $T_{0}(n=20)(401 \pm 14$ versus $395 \pm 9, P=0.9)$ or at $T_{1}(451 \pm$ 19 versus $450 \pm 12, \mathrm{P}=0.8$ ). Whereas in the NAC group there was a non-significant increase in the antioxidants scavenging capacity of plasma at $T_{1}$ as compared to $T_{0}$ (449 \pm 20 versus $394 \pm 16, P=0.1(n=16)$ ), in the placebo group the increase was statistically significant $(450 \pm$ 12 versus $387 \pm 11, P=0.008(n=16)$ ). In both $N A C$ and placebo groups, plasma

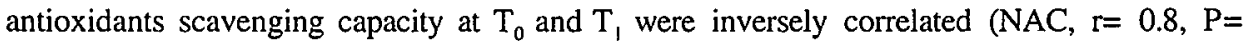
0.002 ; placebo, $\mathrm{r}=0.7, \mathrm{P}=0.01$ ). Plasma antioxidants scavenging data did not correlate with the data on MFC/SPC micronuclei frequencies, MFC/BMC PAH-DNA adducts or BAL cells 8-OH-dG adducts, or PBL/BAL cells lipophilic-DNA adducts or 4-ABP-Hb adducts or urine mutagenicity or plasma/BAL fluid cotinine or smoking status.

There was no significant difference in antioxidants scavenging capacity of BAL fluid between NAC $(n=14)$ and placebo $(n=17)$ groups at $T_{0}(1856 \pm 224$ versus $1787 \pm 176, P=$ $0.8)$ or at $T_{1}(1806 \pm 271$ versus $1777 \pm 272, \mathrm{P}=0.8)$. Neither in NAC nor in placebo groups, was there any significant change in antioxidants scavenging capacity of BAL fluid at $T_{1}$ as compared to $T_{0}(N A C, 1806 \pm 271$ versus $2043 \pm 254, P=0.4(n=11)$; placebo, $1777 \pm 272$ 
versus $1703 \pm 203, P=0.9(n=14))$. Also, there was no correlation between BAL fluid antioxidants scavenging capacity at $T_{1}$ and those at $T_{0}$ in either NAC or placebo groups. BAL fluid antioxidants scavenging capacity data did not correlate with the respective data on MFC/SPC micronuclei frequencies, MFC/BMC PAH-DNA adducts or BAL cells 8-OH-dG adducts or PBL/BAL cells lipophilic-DNA adducts or 4-ABP-Hb adducts or urine mutagenicity or plasma/BAL fluid cotinine or smoking status.

\section{DISCUSSION}

A great deal of experimental studies have shown the effectiveness of NAC in modulating cancer-associated biomarkers $(3,21,24-35)$. However, the chemopreventive effects of NAC in humans have not been verified, yet. Recently, the single large-scale EUROSCAN trial (67), failed to show any efficacy of NAC in preventing or delaying the occurrence of secondary primary tumors in lung or head and neck cancer patients. In the present study, we used a multi-biomarker approach to investigate the chemopreventive effects of NAC in healthy smoking volunteers. The wide array of the investigated markers gave us a unique opportunity to examine the effects of NAC on multiple biological endpoints as well as to explore NAC's mode of action as it has been shown that NAC can exert its effects through a variety of coordinated mechanisms $(20,45,68,69)$.

Quantification of exposure dose makers showed no significant change in the level of plasma/BAL fluid cotinine or urine mutagenicity before and after intervention. This is of importance as it confirms the compliance of the participants with the study protocol and in particular their consistency in smoking behaviors. It should be acknowledged that amongst the three biomarkers, plasma cotinine was the most relevant exposure index since there was a significant correlation between its analyses at pre- and post-intervention times given that the exposure variable [smoking status] was unchanged throughout.

Assessment of biologically effective dose markers showed that NAC could selectively modify some of these biomarkers in specific cells. In fact, NAC significantly inhibited the formation of both lipophilic-DNA adducts and 8-OH-dG adducts in BAL cells, whereas it had no effect on MFC/BMC PAH-DNA adducts, PBL lipophilic-DNA adducts and 4-ABP-Hb adducts. Occurrence of these protective effects in humans is in agreement with the findings of animal studies (30-34). Indeed, in rats exposed whole-body to mainstream cigarette smoke oral NAC attenuated the formation of DNA adducts detected by synchronous fluorescence spectrophotometry, in lung, heart, aorta and kidney $(32,34)$. In the same animals NAC modulated the liver metabolism of mutagens (30) and prevented the histopathologic and cytogenetic damages produced by cigarette smoke (31). Also, a further study in rats exposed whole-body to environmental cigarette smoke showed the ability of NAC to inhibit 8-OH-dG induction in lung DNA and formation of DNA adducts detected by ${ }^{32} \mathrm{P}$ postlabeling, in BAL cells, tracheal epithelium, lung and heart (31). In contrast, in another laboratory oral NAC was found to be ineffective in influencing the levels of DNA adducts in trachea, lung, heart and bladder (70). Comparative analyses, however, showed that this discrepancy is methodological in nature and in particular, is due to the different chromatographic conditions in $\mathrm{D}_{3}$ (Izzotti, et 
al., unpublished data). Apparently, the system in which NAC is ineffective grossly underestimates the overall genotoxic potential of cigarette smoke.

Moreover, the herein efficacy of NAC in an individual cell type is in good agreement with the findings of previous pharmacokinetic studies in animal models reporting a tissue specificity for NAC's uptake and efficacy $(71,72)$. Presumably, NAC is deacetylated to Lcysteine in those organs, which possess the required metabolic machinary for its deacetylation, thereby boosting the intracellular biosynthesis of GSH or adjusting its turnover rate $(3,20,73)$. Although it is still unclear if deacetylation of NAC within the organ is a pre-requisite for its efficacy, it is more likely to observe NAC effects in an organ wherein it is deacetylated rather than in a non-metabolizing organ. For example, whilst being taken up highly by bladder and slightly by lymphocytes, NAC exhibited protective effects against the urotoxicity of cyclophosphamide, but not against the concomitant leukopenia (74,75). This might explain our observed inhibitory effects of NAC on the formation of DNA adducts only in BAL cells provided that this cell type is extensively capable of metabolizing xenobiotics (76-78). The selective inhibition by NAC of DNA adducts in BAL cells and not in PBL or buccal cells could also be ascribed to the higher sensitivity and accessibility of BAL cells to adductinducing agents in cigarette smoke. Interestingly, the higher levels of lipophilic-DNA adducts in BAL cells [more than 4-fold] as compared to those in PBL shown in the present study support this idea.

It is also worthy mentioning that the effectiveness of NAC in downregulating BAL cells lipophilic-DNA adducts was dose-dependently related to exposure to cigarette smoke as NAC exhibited the highest efficacy at the lowest exposure level. This is of relevance particularly in the data analysis of chemoprevention trials since influential variables like exposure, if not taken into account, can easily mislead the investigators in drawing the appropriate conclusions. It is also noteworthy that in the case of NAC's inefficacy, there was an elevation of most biomarkers over time because adduct levels increased in MFC, PBL and $\mathrm{Hb}$ after six months of treatment. Assumingly, the experimental time course of the study might have caused this phenomenon as it has been shown that all these markers can vary seasonally (79-81).

Measurement of biological response markers further reaffirmed the above-mentioned tissue specific-efficacy of NAC as well as provided suggestive evidence on the diversity of NAC's mode of action. As mentioned earlier, there is a rationale of the efficacy of NAC in the organ wherein it is metabolized. The uncertainty, however, arises since the metabolized NAC in a given organ e.g., the liver, may also be taken up by other organs for example via blood circulation (71). In addition, metabolization of NAC or uptake of its metabolites might not necessarily warrant its effectiveness as NAC may exert varying effects through diverse pathways in an individual organ $(20,45,65,71)$. For instance, in rats, when administered orally, NAC was mainly metabolized in the intestinal mucosa; whereas its metabolized form could be detected substantially at this site as well as at bone marrow, there was no modulation of GSH at either site $(73,74)$. In our study, assessment of the biological response markers showed an inhibitory effect of NAC on the formation of micronuclei in buccal cells, which is in agreement with the anti-clastogenic properties of NAC in animal models (65). Moreover, NAC stimulated the antioxidants scavenging capacity in plasma but not in BAL fluid. Comparing this assessment with that of biologically effective dose markers, we found a dual efficacy of NAC within both MFC and BAL cells; whilst NAC significantly decreased the frequency of 
micronuclei in MFC, it did not affect the formation of DNA adducts in the same cell type. Likewise, NAC did not stimulate BAL fluid antioxidants scavenging capacity, whereas it inhibited the formation of DNA adducts in BAL cells. Taken together, along with the findings of previous studies, our observations support the view that NAC may exert varying effects through different pathways of action, thereby exhibiting simultaneous efficacy and inefficacy for various biomarkers in a given organ.

In conclusion, we have demonstrated that NAC can modulate certain smoking-associated biomarkers within specific cells in humans. These results are in agreement with the conclusion of other phase II chemoprevention trials performed with NAC. Thus, in a follow-up of smokers the oral administration of NAC [600 - $800 \mathrm{mg}]$ produced a rapid and significant decrease of urine mutagenicity (82). However, not all the investigated subjects responded to treatment, which may explain the lack of significant differences between the NAC group and the placebo group observed in the present study. This aspect warrants further studies aimed at understanding the mechanisms, which discriminate responders from non-responders. A study in non-smoking patients suffering from alveolar pulmonary fibrosis showed that the daily administration of three oral doses of $600 \mathrm{mg}$ NAC resulted in a significant decline of 4-ABP$\mathrm{Hb}$ adducts over time (83). Furthermore, the daily administration of $800 \mathrm{mg}$ NAC for 12 weeks to patients with previous adenomatous colonic polyps produced a significant decrease of a proliferative index in the colon (84).

It is evident that there is a discrepancy between the protective effects of NAC, as observed in the majority of studies evaluating either preneoplastic conditions and tumors in animal models or biomarkers in both humans and experimental animals, and the lack of effect of NAC in the EUROSCAN phase III chemoprevention trial (67). It should be noted that these studies have differentiated targets. In fact, phase II trials are conducted in a primary prevention setting because the recruited subjects are apparently healthy in terms of neoplastic diseases. Similarly, animal studies mimic a primary prevention situation. In contrast, the EUROSCAN study had the main objective of evaluating the occurrence of second primary tumors in patients curatively treated for head and neck and lung cancer. Since NAC has been recently shown, both in vitro and animal models, to possess anti-invasive and anti-metastatic properties (85) as well as strong anti-angiogenic effects (86), it would be of interest to evaluate possible protective effects of NAC in the context of clinical trials in which the drug should be administered concomitantly with traditional therapy, either surgical or pharmacological or radiological. Studies in mice have in fact shown that NAC and a typical cytostatic drug, doxorubicin, act synergistically in inhibiting the growth of primary tumors and the spread of metastases (87). 


\section{REFERENCE}

1. Ziment, I. (1986) Acetylcysteine: a drug with an interesting past and fascinating future. Respiration, 50, 26-30.

2. Flanagan, R. (1987) The role of Acetylcystein in clinical toxicology. Medical Toxicology, 2, 93-104.

3. De Vries, N. and De Flora S. (1993) N-Acetyle-L-cysteine. J Cell Biochem Suppl, 17F, 270-278.

4. Van Zandwijk. N. (1995) $\mathrm{N}$-acetylcysteine (NAC) and glutathione (GSH): antioxidant and chemopreventive properties, with special reference to lung cancer. $J$ Cell Biochem Suppl, 22, 24-32.

5. Webb, W. (1962) Clinical evaluation of a new mucolytic agent acetylcysteine. $J$ Thorac Cardiovasc Surg, 44, 330-343.

6. Reas, H. (1963) The effect of $\mathrm{N}$-acetylcysteine on the viscosity of tracheobronchial secretions in cystic fibrosis of the pancreas. J Pediatr, 62, 31-35.

7. Richardson, P.S. and Phipps R.J. (1978) The anatomy, physiology, pharmacology and pathology of tracheobronchial mucus secrction and the use of expectorant drugs in human disease. Pharmacol Ther [B], 3, 441-479.

8. Prescott, L.F., Park J., Ballantyne A., Adriaenssens P. and Proudfoot A.T. (1977) Treatment of paracetamol (acetaminophen) poisoning with $N$-acetylcysteinc. Lancet, 2, 432-434.

9. Prescott, L.F., Illingworth R.N., Critchley J.A., Stcwart M.J., Adam R.D. and Proudfoot A.T. (1979) Intravenous $N$-acetylcysteine: the treatment of choice for paracetamol poisoning. $\mathrm{Br}$ Med $J, 2,1097$ 1100.

10. Aylward, M., Maddock J. and Dewland P. (1980) Clinical evaluation of acetylcysteine in the treatment of patients with chronic obstructive bronchitis: a balanced double-blind trial with placebo control. Eur $J$ Respir Dis Suppl, 111, 81-89.

11. Multi-center Study Group (1980) Long-term oral acetylcysteine in chronic bronchitis: a double-blind controlled study. Eur J Resp Dis, 61 (Suppl III), 93-108.

12. Boman, G. and Gazzaniga A. (1983) Oral acetylcysteine reduces exacerbation rate in chronic bronchitis: Report of a trail organized by the Swedish Society for Pulmonary Diseases. Eur $J$ Resp Dis, 64, 405415.

13. Crystal, R.G. and Bast A. (1991) Oxidants and antioxidants: pathophysiologic determinants and theraputic agents. Am J Med, 91, 1s-145s.

14. De Flora, S., Izzotti A., D'Agostini F. and Cesarone C.F. (1991) Antioxidant activity and other mechanisms of thiols involved in chemoprevention of mutation and cancer. Am J Med, 91, 122S$130 \mathrm{~S}$.

15. De Flora, S., Grassi C. and Carati L. (1997) Attenuation of influenza-like symptomatology and improvement of cell-medialed immunity with long-term $\mathrm{N}$-acetylcysteine treatment. Eur Respir J, 10 , 1535-1541.

16. Dröge, W. (1993) Cysteine and glutathione deficiency in AIDS patients: a rationale for the treatment with $N$-acetyl-cysteine. Pharmacology, 46, 61-65.

17. Rasmussen, K., Weibke G., Hibbs J.J. and Evans G. (1993) Nitric oxide synthesis, nitrogen balance and $N$-acetylcysteine therapy in patients with advanced HIV infection. Clin Res, 41, 89A.

18. Bonanomi, L. and Gazzaniga A. (1980) Toxicological, pharmacokinetic and metabolic studies of acetylcysteine. Eur J Respir Dis, 61 (Suppl III), 45-51. 
19. De Flora, S., Izzotti A., D'Agostini F., Balansky R. and Cesarone C.F. (1992) Chemopreventive properties of $N$-acetylcystcine and other thiols. In Wattenberg, L., Lipkin, M., Boone, C.W. and Kelloff, G.J. (eds), Cancer Chemoprevention. CRC Press, Boca Raton, pp. 183-194.

20. De Flora, S., Balansky R., Bennicelli C., Camoirano A., D'Agostini F., Izzotti A. and Cesarone C. (1995) Mechanisms of anticarcinogenesis: the example of $\mathrm{N}$-acetylcysteinc. In Ioannides, $\mathrm{C}$. and Lewis, D.F.V. (eds.), Drugs, Diet and Disease. Voi. 1. Mechanistic approaches to cancer. Horwood Ellis, Hemel Hempstead, pp. 151-203.

21. De Flora, S., Cesarone C.F., Balansky R.M., Albini A., D'Agostini F., Bennicelli C., Bagnasco M., Camoirano A., Scatolini L., Rovida A. and et al. (1995) Chemopreventive properties and mechanisms of $N$-Acetylcysteine. The experimental background. J Cell Biochem Suppl, 22, 33-41.

22. Kelloff, G.J., Crowell J.A., Boone C.W., Stecle V.E., Lubet R.A., Greenwald P., Alberts D.S., Covey J.M., Doody L.A., Knapp G.G. and et al. (1994) Clinical development plan: $N$-Acetyl-L-cysteine. $J$ Cell Biochem Suppl, 20, 63-73.

23. Kelloff, G.J., Boone C.W., Steele V.E., Fay J.R., Lubet R.A., Crowell J.A. and Sigman C.C. (1994) Mechanistic considerations in chemopreventive drug development. J Cell Biochem Suppl, 20, 1-24.

24. De Flora, S., Astengo M., Serra D. and Bennicelli C. (1986) Inhibition of urethane-induced lung tumors in mice by dietary $N$-acetylcysteine. Cancer Lett, 32, 235-241.

25. Rogers, D.F. and Jeffery P.K. (1986) Inhibition by oral $N$-acetylcysteine of cigarette smoke-induced "bronchitis" in the rat. Exp Litung Res, 10, 267-283.

26. Wilpart, M., Speder A. and Roberfroid M. (1986) Anti-initiation activity of $N$-acetylcysteine in experimental colonic carcinogenesis. Cancer Lett, 31, 319-324.

27. De Flora, S., D'Agostini F., Izzotti A. and Balansky R. (1991) Prevention by $N$-acetylcysteine of benzo[a]pyrene clastogenicity and DNA adducts in rats. Mutat Res, 250, 87-93.

28. Izzotti, A., Bagnasco, M, D'Agostini, F, Scarabelli, L, and Cesarone, CF (1991) Chemoprevention of carcinogen-DNA adduct formation. In Pastorino, U. and Hong, W. (eds), Chemoimmunoprevention of Cancer: Thicme-Verlag, New York, pp. 15-19.

29. Pereira, M.A. and Khoury M.D. (1991) Prevention by chemopreventive agents of azoxymethane-induced foci of abetrant crypts in rat colon. Cancer Lett, 61, 27-33.

30. Bagnasco, M., Bennicelli C., Camoirano A., Balansky R.M. and De Flora S. (1992) Metabolic alterations produced by cigarette smoke in rat lung and liver, and their modulation by oral $N$ acetylcysteine. Mutagenesis, 7, 295-301.

31. Balansky, R.B., D'Agostini F., Zanacchi P. and De Flora S. (1992) Protection by $N$-acetylcysteine of the histopathological and cytogenetical damage produced by exposure of rats to cigarette smokc. Cancer Lett, 64, 123-131.

32. Izzoti, A., Balansky R.M., Coscia N., Scatolini L., D'Agostini F. and De Flora S. (1992) Chemoprevention of smoke-related DNA adduct formation in rat lung and heart. Carcinogenesis, 13, 2187-2190.

33. Izzotti, A., D'Agostini F., Bagnasco M., Scatolini L., Rovida A., Balansky R.M., Cesarone C.F. and De Flora S. (1994) Chemoprevention of carcinogen-DNA adducts and chronic degenerative diseases. Cancer Res, 54, 1994s-1998s.

34. Izzotti, A., Balansky R., Scatolini L., Rovida A. and De Flora S. (1995) Inhibition by $N$-acetylcysteine of carcinogen-DNA adducts in the tracheal epithelium of rats exposed to cigarette smoke. Carcinogenesis, 16, 669-672. 
35. Balansky, R., Izzotti A., Scatolini L., D'Agostini F. and De Flora S. (1996) Induction by carcinogens and chemoprevention by $\mathrm{N}$-acetylcystcine of adducts to mitochondrial DNA in rat organs. Cancer Res, 56, 1642-1647.

36. Labrid, C., Ducher M., Dureng G., Moleyre J., Stevenard M. and Streichenberger G. (1973) Comparative study of various inhibitors of immunologically induced joint edema in the guinea pig. Therapie, 28, 907-921.

37. Albano. E., Poli G., Tomasi A., Bini A., Vannini V. and Dianzani M.U. (1984) Toxicity of 1,2dibromoethane in isolated hepalocytes: role of lipid peroxidation. Chem Biol Interact, 50, 255-265.

38. De Flora, S., Bennicelli C., Zanacchi P., Camoirano A., Morelli A. and De Flora A. (1984) In vitro effects of $\mathrm{N}$-acctylcystcine on the mutagenicity of direct-acting compounds and procarcinogens. Carcinogenesis. 5, 505-510.

39. De Flora, S., Bennicelli C., Camoirano A., Serra D., Romano M., Rossi G.A., Morelli A. and De Flora A. (1985) In vivo effects of $\mathrm{N}$-acetylcysteine on glutathione metabolism and on the biotransformation of carcinogenic and/or mutagenic compounds. Carcinogenesis, 6, 1735-1745.

40. De Flora. S., Astengo M.. Serra D. and Bennicelli C. (1986) Inhibition of urethane-induced lung tumors in mice by dielary $N$-acctylcysteine. Cancer Lett, 32, 235-241.

41. Dorsch, W., Auch E. and Powerlowicz P. (1987) Adverse effects of acclylcysteine on human and guinea pig bronchial asthma in vivo and on human fibroblasts and leukocytes in vitro. Imt Arch Allergy Appl Immunol, 82, 33-39.

42. Perchellet, E.M., Maatta E.A., Abney N.L. and Perchellet J.P. (1987) Effects of diverse intracellular thiol delivery agents on glutathione peroxidase activity, the ratio of reduced/oxidized glutathione, and ornithine decarboxylase induction in isolated mouse epidermal cells treated with 12-Otetradecanoyiphorbol-13-acetate. J Cell Physiol, 131, 64-73.

43. Perchellet, J.P., Abney N.L., Thomas R.M., Perchellet E.M. and Maatta E.A. (1987) Inhibition of multistage tumor promotion in mouse skin by diethyldithiocarbamate. Cancer Res, 47, 6302-6309.

44. Cesarone, C.F., Scovassi A.I., Scarabelli L., Izzo R., Orunesu M. and Bertazzoni U. (1988) Depletion of adenosine diphosphate-ribosyl transferase activity in rat liver during exposure to $\mathrm{N}-2$ acetylaminofluorene: effect of thiols. Cancer Res, 48, 3581-3585.

45. De Flora, S. and Ramel C. (1988) Mechanisms of inhibitors of mutagenesis and carcinogenesis. Classification and overview. Mutat Res, 202, 285-306.

46. Hochstein, P. and Atallah A.S. (1988) The nature of oxidants and antioxidant systems in the inhibition of mutation and cancer. Mutat Res, 202, 363-375.

47. Joshi, U.M., Kodavanti P.R. and Mehendale H.M. (1988) Glutathione metabolism and utilization of external thiols by cigarette smoke-challenged, isolated rat and rabbit lungs. Toxicol Appl Pharmacol, 96, 324-335.

48. Weinander, R., Anderson C. and Morgenstern R. (1994) Identification of $N$-acctylcysteine as a new substrate for rat liver microsomal glutathione transferase. A study of thiol ligands. $J$ Biol Chem, 269 , 71-76.

49. Wilcosky, T.C. and Griffith J.D. (1990) Application of biological markers. In Hulska, B.S., Wilcosky, T.C. and Griffith, J.D. (eds), Biological markers in epidemiology. Vol. 1. Oxford University Press, New York, pp. 16-27.

50. Yamasaki, E. and Ames B.N. (1977) Concentration of mutagens from urine by absorption with the nonpolar resin XAD-2: cigarcte smokers have mutagenic urine. Proc Natl Acad Sci U S A, 74, 35553559. 
51. Bøyum, A. (1976) Isolation of lymphocytcs, granulocytes and macrophages. Scand J Immunol, 5, 9-15.

52. Bryant, M.S., Skipper P.L., Tannenbaum S.R. and Maclure M. (1987) Hemoglobin adducts of 4aminobiphenyl in smokers and nonsmokers. Cancer Res, 47, 602-608.

53. Van Schooten, F.J., Godschalk R.W., Breedijk A., Maas L.M., Kriek E., Sakai H., Wigbout G., Baas P., Van't Veer L. and Van Zandwijk N. (1997) "2P-postlabelling of aromatic DNA adducts in white blood cells and alveolar macrophages of smokers: saturation at high exposures. Mutat Res, 378, 65-75.

54. Nia, A.B., Maas L.M., Van Breda S.G., Curfs D.M., Kleinjans J.C., Wouters E.F. and Van Schooten F.J. (2000) Applicability of induced sputum for molecular dosimetry of exposure to inhalatory carcinogens: ${ }^{32}$ P-postlabeling of lipophilic DNA adducts in smokers and nonsmokers. Cancer Epidemiol Biomarkers Prev, 9, 367-372.

55. Langone, J.J., Gjika H.B. and Van Vunakis H. (1973) Nicotine and its metabolites. Radioimmunoassays for nicotine and cotininc. Biochemistry, 12, 5025-5030.

56. Haley, N.J., Axelrad C.M. and Tilton K.A. (1983) Validation of self-reported smoking behavior: biochemical analyses of cotinine and thiocyanate. Am J Public Health, 73, 1204-1207.

57. De Flora, S., Balansky R., Gasparini L. and Camoirano A. (1995) Bacterial mutagenicity of cigarette smoke and its interaction with ethanol. Mutagenesis, 10, 47-52.

58. Dallinga, J.W., Pachen D.M., Wijnhoven S.W., Breedijk A., van 't Veer L., Wigbout G., van Zandwijk N., Maas L.M., van Agen E., Kleinjans J.C. and van Schooten F.J. (1998) The use of 4aminobiphenyl hemoglobin adducts and aromatic DNA adducts in lymphocytes of smokers as biomarkers of exposurc. Cancer Epidemiol Biomarkers Prev, 7, 571-577.

59. Izzolli, A., Orlando M., Gasparini L., Scatolini L., Cartiglia C., Tulimiero L. and De Flora S. (1998) In vitro inhibition by $\mathrm{N}$-acetylcysteine of oxidative DNA modifications detected by ${ }^{32} \mathrm{P}$-postlabeling. Free Rad Res, 28, 165-178.

60. Izzotti, A., Cartiglia C., Taningher M., De Flora S. and Balansky R. (1999) Age-related increases of 8 hydroxy-2'-deoxyguanosine and DNA-protein crosslinks in mouse organs. Mutat Res, 446, 215-223.

61. Nia, A.B., Van Straaten H.W., Kleinjans J.C. and Van Schooten F.J. (2000) Immunoperoxidase detection of 4-aminobiphenyl-and polycyclic aromatic hydrocarbons-DNA adducts in induced sputum of smokers and non-smokers. Mutat Res, 468, 125-135.

62. Santella, R.M., Lin C.D., Clcveland W.L. and Weinstcin I.B. (1984) Monoclonal antibodies to DNA modified by a benzo[a]pyrene diol epoxide. Carcinogenesis, 5, 373-377.

63. Santella, R.M., Dharmaraja N., Gasparro F.P. and Edeison R.L. (1985) Monoclonal antibodies to DNA modified by 8-methoxypsoralen and ultraviolet A light. Nucleic Acids Res, 13, 2533-2544.

64. Belien, J.A., Copper M.P., Braakhuis B.J., Snow G.B. and Baak J.P. (1995) Standardization of counting micronuclei: definition of a protocol to measure genotoxic damage in human exfoliated cells. Carcinogenesis, 16, 2395-2400.

65. Balansky, R.M., D'Agostini F. and De Flora S. (1999) Induction, persistence and modulation of cytogenetic alterations in cells of smoke-exposed mice. Carcinogenesis, 20, 1491-1497.

66. Van den Berg, R., Haenen, GRMM, Van den Berg, H and Bast, A (1999) Applicability of an improved Trolox equivalent antioxidant capacity (TEAC) assay for cvaluation of antioxidant capacity measurements of mixtures. Food Chemistry, 66, $511-517$.

67. Van Zandwijk, N., Dalesio O.. Pastorino U., de Vries N. and van Tinteren H. (2000) EUROSCAN, a randomized trial of vitamin $\mathrm{A}$ and $\mathrm{N}$-acetylcysteine in patients with head and neck cancer or lung cancer. For the European Organization for Research and Treatment of Cancer Head and Neck and Lung Cancer Cooperative Groups. J Natl Cancer Inst, 92, 977-986. 
68. De Flora, S., Bagnasco M. and Zanacchi P. (1992) Classification and mechanism of action of chemopreventive compounds. In De Palo, G., Sporn, M. and Veronesi, U. (eds), Progress and Perspectives in Chemoprevention of Cancer. Raven Press, New York, pp. 1-11.

69. De Flora, S., Izzotti A. and Bennicelli C. (1993) Mechanisms of antimutagenesis and anticarcinogenesis. Role in primary prevention. In Bronzetti, G., Hayatsu, H., De Flora, S., Waters, M.D. and Shankel, D.M. (cds), Antimuragenesis and Anticarcinogenesis Mechanisms III. Plenum Press, New York, pp. 1-16.

70. Arif, J.M., Cairola C.G., Glauert H.P., Kelloff G.J., Lubet R.A. and Gupta R.C. (1997) Effects of dietary supplementation of $\mathrm{N}$-acetylcysteine on cigarette smoke-related DNA adducts in rat tissues. $\mathrm{Int} J$ Oncol, 11, 1227-1233.

71. McLellan, L.I., Lewis A.D., Hall D.J., Ansell J.D. and Wolf C.R. (1995) Uptake and distribution of Nacetylcysteine in mice: tissue-specific effects on glutathione concentrations. Carcinogenesis, 16, 20992106.

72. Cotgreave, I.A. (1997) $N$-acetylcysteine: pharmacological considcrations and experimental and clinical applications. Adv Pharmacol, 38, 205-227.

73. Sjödin, K., Nilsson, E, Hallherg, A, and Tunek, A (1989) Metabolism of $N$-acetyl-L-cysteine. Some structural requirements for the deacetylation and consequences for the oral bioavailability. Biochem Pharmacol, 38, 3981-3985.

74. Gurtoo, H., Marinello A., Berrigan M., Bansal S., Paul B., Pavelic Z. and Struck R. (1983) Effect of thiols on toxicity and carcinostatic activity of cyclophosphamide. Semin Oncol, 10, 35-45.

75. Holoye, P. (1983) Prophylaxis of isosfamide toxicity with oral acetylcysteine. Semin Oncol, 10 (Suppl. 1), 66-77.

76. Harris, C., Hsu I., Stoner G., Trump B. and Selkirk J. (1978) Human pulmonary alveolar macrophages metabolise benzo[a]pyrene to proximate and ultimate mutagens. Nature, 272, 633-634.

77. Petrilli, F., Rossi G., Camoirano A., Romano M., Serra D., Bennicelli C., De Flora A. and De Flora S. (1986) Metabolic reduction of chromium by alveolar macrophages and its relationships to cigarctte smoke. J Clin Invest, 77, 1917-1924.

78. Petruzzelli, S., Bernard P., Paoletti P., Rane A., Giuntini C. and Pacilici G. (1988) Presence of epoxide hydrolase and glutathione $S$-transferase in human pulmonary alveolar macrophages. Eur $\mathrm{J}$ Clin Pharmacol, 34, 419-421.

79. Grzybowska, E., Hemminki K., Szeliga J. and Chorazy M. (1993) Seasonal variation of aromatic DNA adducts in human lymphocyles and granulocytes. Carcinogenesis, 14, 2523-2526.

80. Grzybowska, E., Hemminki K. and Chorazy M. (1993) Seasonal variations in levels of DNA adducts and $\mathrm{X}$-spots in human populations living in different parts of Poland. Environ Health Perspect, 99, 77 81.

81. Moller, L.. Grzybowska E., Zeisig M., Cimander B., Hemminki K. and Chorazy M. (1996) Seasonal variation of DNA adduct pattern in human lymphocytes analyzed by ${ }^{32} \mathrm{P}-\mathrm{HPLC}$. Carcinogenesis, 17 , 61-66.

82. De Flora, S., Camoirano A., Bagnasco M., Bennicelli C., van Zandwijk N., Wigbout G., Qian G.S., Zhu Y.R. and Kensler T.W. (1996) Smokers and urinary genotoxins: implications for selection of cohorts and modulation of endpoints in chemoprevention trials. J Cell Biochem Suppl, 25, 92-98.

83. Rösler, S., Behr J. and Richter E. (1999) N-acetylcysteine treatment lowers 4-aminobiphenyl haemoglobin adduct levels in non-smokers. Eur J Cancer Prev, 8, 469-472. 
84. Estensen, R.D., Levy M., Klopp S.J., Galbraith A.R., Mandel J.S., Blomquist J.A. and Wattenberg L.W. (1999) $\mathrm{N}$-acetylcysteine suppression of the proliferative index in the colon of patients with previous adenomatous colonic polyps. Cancer Lett, 147, 109-114.

85. Albini, A., D'Agostini F., Giunciuglio D., Paglieri I., Balansky R. and De Flora S. (1995) Inhibition of invasion, gelatinase activity, tumor take and metastasis of malignant cells by $\mathrm{N}$-acetylcysteine. Int $\mathrm{J}$ Cancer, 61, $121-129$.

86. Cai, T., Fassina G., Morini M., Aluigi M.G., Masiello L., Fontanini G., D'Agostini F., De Flora S., Noonan D.M. and Albini A. (1999) $N$-acetylcysteine inhibits endothelial cell invasion and angiogencsis. Lab Invest, 79, 1151-1159.

87. De Flora, S., D'Agostini F., Masicllo L., Giunciuglio D. and Albini A. (1996) Synergism between $N$ acelylcysteine and doxorubicin in the prevention of tumorigenicity and metastasis in murine models. Int $J$ Cancer, 67, 842-848. 


\section{CHAPTER 9}

SUMMARY AND CONCLUSION 


\section{Chapter Nine}

\section{Summary and conclusion}

A large body of evidence has shown that tobacco smoking is involved in the etiology of several human cancers $(1,2)$. Tobacco smoke carcinogenicity is largely ascribed to its DNAreactive constituents (3). These compounds comprise a wide range of chemicals with specific structures, which enable them to bind covalently to DNA and form DNA adducts (3). Formation of DNA adducts is an event of potential significance in carcinogenesis because it may give rise to chromosomal aberrations, DNA strand breaks, oncogene activation and tumor suppressor gene inactivation (4-6). By definition, DNA adducts are the biologically effective dose markers of exposure to carcinogens. That is that they not only represent a prior exposure to carcinogens but they also imply a risk for cancer (5). Of course, the implication of DNA adducts in cancer is not straightforward. The fact is that other processes such as cellular proliferation along with, or separate from DNA adduct formation may modulate carcinogenesis $(5,7)$. Therefore, interpretation of DNA adduct data in relation to cancer ought to be done cautiously. Theoretically, dosimetry of DNA adducts should be performed within the organs where tumor arises [target organs]. Practically, however, most target organs for tobacco-associated cancers are only invasively accessible $(8,9)$. Also, the commonly used nontarget organs show inconsistent surrogacy for the target ones $(10,11)$. The latter is mainly due to the incomparability of exposure patterns in surrogate versus target organs. In addition, different cell compositions with varying biotransformational and DNA repair capacities in target and surrogate organs may also be responsible for such inconsistency $(12,13)$.

In the present thesis, we explored the carcinogenicity of tobacco smoke in humans by dosimetry of DNA adducts in various target and surrogate matrices. Focusing on three major classes of DNA adduct-inducing agents, polycyclic aromatic hydrocarbons (PAH), aromatic amines and reactive oxygen species (ROS), we studied the representative DNA adducts, benzo[a]pyrene diol epoxide (BPDE) -DNA adducts, 4-aminobiohenyl (4-ABP) -DNA adducts and 8-oxo-7,8-dihydroguanine (8-oxo-Gua), respectively (14-17).

In chapter 2, we examined the validity of DNA adduct analysis in induced sputum (IS), a non-invasive derivative from the lower airway (18). We detected significantly higher levels of smoke-related DNA adducts in IS of smokers as compared to non-smokers by both versions of the ${ }^{32}$ P-postlabeling assay, the nuclease P1 digestion and the butanol extraction methods. The similarity and correlation between the levels of adducts quantified by different enhancement methods confirm the previous findings by others indicating the PAH-derived nature of adducts in the lower respiratory tract (19-21). Technically, the NP1 digestion method degrades the C8-guanine-adducted nucleotides of aromatic amines and substantially enhances the $\mathrm{N}^{2}$-guanine adducts, whereas the butanol extraction method enriches both types of adducts (22). Furthermore, the dose-dependency of smoke-related DNA adducts in IS suggests that this matrix can be used for molecular dosimetry of inhalatory carcinogens. Also, the comparability of our results to those obtained in bronchoalveolar lavage (BAL) cells, an already validated but invasively accessible matrix (23-25), implies that sputum induction may replace the BAL method for sampling airway. 
In chapter 3, we validated DNA adduct dosimetry in IS and further, compared it with dosimetry of DNA adducts in peripheral blood lymphocytes (PBL) (26). First and foremost, DNA adduct analysis in IS produced similar results to what we had previously reported (18). Also, repeated measurement of DNA adducts in IS and PBL showed a consistency in the level of adducts in both matrices [over a three-week period]. Comparatively, adduct analysis in IS was more explicit than that in PBL both qualitatively and quantitatively. Moreover, there were some indications of the persistency of DNA adducts in PBL. For example, DNA adduct levels in PBL were dependent on the cumulative dose of exposure to tobacco smoke [pack years]. In addition, the levels of adducts in PBL did not drop as drastic as those in IS after smoking cessation. Altogether, it appears that dosimetry of DNA adducts in IS is a choice of preference for studying tobacco smoke carcinogenicity.

In chapter 4, we separately quantified aromatic amine- and PAH-DNA adducts in IS by immunohistochemistry of 4-ABP- and BPDE-DNA adducts, respectively (27). We found that the levels of both types of adducts were dose-dependently related to the current smoking intensity; however, the results were more pronounced for 4-ABP-DNA adducts. On the one hand, this shows the specificity of immunohistochemistry of 4-ABP-DNA adducts. On the other hand, it suggests that ubiquitous confounding exposure to PAH (28) may impact upon immunohistochemistry of BPDE-DNA adducts. Undoubtedly, the high levels of BPDE-DNA adducts in some of the non-smokers and the wider range of BPDE-DNA adducts as compared to 4-ABP-DNA adducts in non-smokers reinforce this view.

In chapter 5, we used DNA adduct dosimetry in IS and PBL together with ambient air monitoring for assessing non-smokers' exposure to environmental tobacco smoke (ETS). Our air monitoring data showed that spending an average period of time in a smoky pub results in relatively high exposure to ETS. Accordingly, we found reasonable enhancement in smokerelated DNA adducts in IS but not in PBL after the pub visit. Of most significance was the formation of BPDE-DNA adducts in IS of a few individuals at post-exposure time. Noteworthily, this adduct is formed at the mutational hotspots of lung cancer $(6,29)$ for which ETS exposure is a known risk factor (30-33). Taken together, the results of this pilot study indicate that DNA adduct analysis in IS might potentially be used as an integral approach to assess ETS exposure as well as to study ETS-related cancers.

In chapter 6, we explored the relevance of markers of oxidative DNA damage/repair as well as antioxidative defense mechanisms for studying tobacco smoke carcinogenicity (34). Although it is a known fact that smoking induces oxidative stress, we found a down regulation of ROS-induced DNA damage (17) in smokers. We hypothesized that this phenomenon may occur as a result of adaptation of antioxidative defense and/or DNA repair systems in smokers. However, quantification of the antioxidative capacity of plasma and genotyping of a relevant antioxidant enzyme, glutathione $S$-transferase M1 (GSTMI) did not support this hypothesis. Also, measurement of the overall DNA repair activity and genotyping of a specific DNA repair enzyme, human 8-hydroxyl-2'-deoxyguanosine (8-OH-dG) glycosylase/apurinic lyase ( $h O G G 1$ ) were not supportive of this hypothesis. Given the controversial results of other studies (35-41), we may consider that the herein-quantified markers are not specific and sensitive to show the subtle effects of smoking. For example, the low prevalence of $h O G G l$ polymorphism may easily mask the impact of this genotype on DNA repair pathway in small-scale studies. It is worthy mentioning that in our study most 
evaluated pathways were highly influenced by host co-factors. For instance, our multiple regression analysis revealed that the non-significant up regulation of plasma antioxidants scavenging capacity in smokers was mainly gender-related. Accordingly, adjustment of data for gender bridged the gap between smokers' and non-smokers' antioxidative capacity. Moreover, males who are under greater oxidative burden due to their higher metabolic rates (42), had lower level of oxidative DNA damage, which was explained by their elevated plasma antioxidants scavenging capacity. Altogether, it seems that the current markers of oxidative DNA damage/repair and antioxidative defense mechanisms need further validation before they can be used for studying tobacco smoke carcinogenicity in humans.

In chapter 7, we investigated the predictive value of DNA adducts for exposure to tobacco smoke and risk for oral cancer (43). Immunohistochemistry of PAH-DNA adducts in two different regions of the oral cavity with varying cancer susceptibility profiles (44-46) showed a dose-dependency of DNA adducts with regard to current smoking intensity. However, PAH-DNA adduct levels in situ did not correspond with the cancer proneness of the respective subsite. In fact, mouth floor cells, which are highly cancer susceptible had lower level of DNA adducts compared to buccal mucosa cells. Apparently, DNA adduct formation in the oral cavity is a consequence of exposure to tobacco smoke rather than a pre-requisite for developing oral cancer. Thus, dosimetry of DNA adducts in the oral cells can safely mirror the exposure to tobacco smoke. Yet, the complexity of the multi-stage process of carcinogenesis (5) makes it unpredictable by DNA adduct dosimetry per se.

In chapter 8 , we quantified various smoke-associated markers to verify the efficacy of chemopreventive agent $\mathrm{N}$-acetyl-L-cysteine (NAC) in humans. We assessed the effects of NAC on different biological endpoints because NAC has been shown to exert its effects through a variety of coordinated mechanisms (47-50). Accordingly, we found that NAC could modulate certain markers within specific matrices. For example, NAC significantly inhibited the formation of DNA adducts in the BAL cells but not in the oral mucosa or PBL. Also, we observed a dual effects of NAC [efficacy/inefficacy] within the individual matrices. For instance, the selectivity of NAC in inhibiting DNA adducts, boosting antioxidative capacity and preventing cytogenetic damages [micronuclei frequency] were independent of each other. Taken together, our results reaffirm the previous experimental data, which have shown a tissue specificity for uptake and efficacy of NAC (51-62). At the same time, they reiterate the importance of a multi-biomarker approach to study the underlying mechanisms of carcinogenesis.

Summarizing the herein-presented data and those from the literature, we may consider that dosimetry of PAH- and aromatic amine-DNA adducts in target and relevant surrogate matrices eg., induced sputum is a valuable means to study tobacco smoke carcinogenicity in humans. However, the relevance of ROS-induced DNA adducts and other oxidative stressassociated markers for such study remain to be seen. To better understand the smokinginduced carcinogenesis in humans and the roles that are played by chemical carcinogens in it, future large-scale research is needed. Such investigations should be conducted in a multidisciplinary way to elucidate the impact of specific DNA adducts in target and validated surrogate matrices, along with genotyping/phenotyping of biotransformational and DNA repair enzymes. 


\section{REFERENCE}

1. Pisani, P., Parkin D.M., Bray F. and Ferlay J. (1999) Estimates of the worldwide mortality from 25 cancers in 1990. Int J Cancer, 83, 18-29.

2. Ferlay, J., Parkin D.M. and Pisani P. (1998) GLOBOCAN. In International Agency for Research on Cancer. Cancer Base (ed.), Cancer incidence and mortality worldwide (CD-rom). Vol. 3. International Agency for Research on Cancer, Lyon (France).

3. Hecht, S.S. (1996) Carcinogenesis due to tobacco: molecular mechanisms. In Bertino, J.R. (ed.), Encyclopedia of cancer. Academic Press, San Dicgo (CA), pp. 220-232.

4. Ross, J.A., Nelson G.B., Wilson K.H., Rabinowitz J.R., Galati A., Stoner G.D., Nesnow S. and Mass M.J. (1995) Adenomas induced by polycyclic aromatic hydrocarbons in strain $A / J$ mouse lung correlate with time-integrated DNA adduct levels. Cancer Res, 55, 1034-1044.

5. Hemminki, K. (1993) DNA adducts, mutations and cancer. Carcinogenesis, 14, 2007-2012.

6. Denissenko, M.F., Pao A., Tang M. and Pfeifer G.P. (1996) Preferential formation of benzola]pyrene adducts at lung cancer mutational hotspots in P53. Science, 274, 430-432.

7. Goldring, J. and Lucier G. (1990) Protein and DNA adducts. In Hulka, B.S., Wilcosky, T. and Griffith, J. (eds), Biological markers in epidemiology. Vol. I. Oxford University Press, New York, pp. 78-104.

8. Wilcosky, T.C. and Griffith J.D. (1990) Application of biological markers. In Hulska, B.S., Wilcosky, T.C. and Griffith, J.D. (eds), Biological markers in epidemiology. Vol. 1. Oxford University Press, New York, pp. 16-27.

9. Wilcosky, T.C. (1990) Criteria for selecting and cvaluating markers. In Hulska, B.S., Wilcosky, T.C. and Griffith, J.D. (eds), Biological markers in epidemiology. Oxford University Press, New York, pp. 28-55.

10. Poirier, M.C. and Weston A. (1996) Human DNA adduct measurements: state of the art. Environ Health Perspect, 104 Suppl 5. 883-893.

11. Phillips, D.H. (1996) DNA adducts in human tissues: biomarkers of exposure to carcinogens in tobacco smoke. Environ Health Perspect, 104 Suppl 3, 453-458.

12. Butkiewicz, D.. Grzybowska E., Hemminki K., Ovrebo S., Haugen A., Motykiewicz G. and Chorazy M. (1998) Modulation of DNA adduct levels in human mononuclear white blood cells and granulocyles by CYPIA1, CYP2D6 and GSTMI genetic polymorphisms. Mutat Res, 415, 97-108.

13. Knudsen, L.E., Ryder L.P. and Wasserman K. (1992) Induction of DNA repair synthesis in human monocytcs/B-lymphocytes compared with T-lymphocytes after exposure to $\mathrm{N}$-acetoxy- $\mathrm{N}$ acctylaminofluorene and dimethylsulfate in vitro. Carcinogenesis, 13, 1285-1287.

14. Hoffmann, D. and Hoffmann I. (1997) The changing cigarette, 1950-1995. J Toxicol Environ Health, 50, 307-364.

15. International Agency for Research on Cancer (1986) Tobacco smoking, Monographs on the evaluation of the carcinogenic risk of chemicals to humans. Vol. 38. International Agency for Research on Cancer, Lyon (France), pp. 37-375.

16. Beland, F.A. and Kadlubar F.F. (1990) Metabolic activation and DNA adducts of aromatic amines and nitroaromatic hydrocarbons. In Cooper, C.S. and Grover, P.L. (eds), Chemical carcinogenesis cand mutagenesis I. Vol. 94/I. Springer-Verlag, Berlin-Heidelberg, pp. 297-325.

17. Cheng, K.C., Cahill D.S., Kasai H., Nishimura S. and Loeb L.A. (1992) 8-Hydroxyguanine, an abundant form of oxidative DNA damage, causes $\mathrm{G} \rightarrow \mathrm{T}$ and $\mathrm{A} \rightarrow \mathrm{C}$ substitutions. $J$ Biol Chem, 267, 166-172. 
18. Nia, A.B., Maas L.M., Van Breda S.G., Curfs D.M., Kleinjans J.C., Wouters E.F. and Van Schooten F.J. (2000) Applicability of induced sputum for molecular dosimetry of exposure to inhalatory carcinogens: "2P-postlabeling of lipophilic DNA adducts in smokers and nonsmokers. Cancer Epidemiol Biomarkers Prev, 9, 367-372.

19. Van Schooten, F.J., Hillebrand M.J., Van Lecuwen F.E., Lutgerink J.T., Van Zandwijk N., Jansen H.M. and Kriek E. (1990) Polycyclic aromatic hydrocarbon-DNA adducts in lung tissue from lung cancer patients. Carcinogenesis, 11, 1677-1681.

20. Weston, A. and Bowman E.D. (1991) Fluorescence detection of benzo[a]pyrene-DNA adducts in human lung. Carcinogenesis, 12, 1445-1449.

21. Alexandrov, K., Rojas M., Geneste O., Castegnaro M., Camus A.M., Petruzzelli S., Giuntini C. and Bartsch H. (1992) An improved fuorometric assay for dosimetry of benzo[a]pyrene diol-epoxide-DNA adducts in smokers' lung: comparisons with total bulky adducts and aryl hydrocarbon hydroxylase activity. Cancer Res, 52, 6248-6253.

22. Gupta, R.C. (1993) ${ }^{32}$ P-postlabelling analysis of bulky aromatic adducts. In Phillips, D.H., Castegnaro, M. and Bartsch, H. (eds), Postlabeling methods for detection of DNA adducts. International Agency for Research on Cancer, Lyon.

23. Izzotti, A., Rossi G.A., Bagnasco M. and De Flora S. (1991) Benzo[a]pyrene diolepoxide-DNA adducts in alveolar macrophages of smokers. Carcinogenesis, 12, 1281-1285.

24. Van Schooten, F.J., Godschalk R.W., Breedijk A., Maas L.M., Kriek E., Sakai H., Wigbout G., Baas P., Van't Veer L. and Van Zandwijk N. (1997) ${ }^{32} \mathrm{P}$-postlabelling of aromatic DNA adducts in white blood cells and alveolar macrophages of smokers: saturation at high exposures. Mutat Res, 378, 65-75.

25. De Flora, S., Izzotti A., D'Agostini F., Rossi G.A. and Balansky R.M. (1993) Pulmonary alveolar macrophages in molecular epidemiology and chemoprevention of cancer. Environ Health Perspect, 99 , 249-252.

26. Nia, A.B., Maas L.M., Brouwer E.M., Kleinjans J.C. and Van Schooten F.J. (2000) Comparison between smoking-related DNA adduct analysis in induced sputum and peripheral blood lymphocytes. Carcinogenesis, 21, 1335-1340.

27. Nia, A.B., Van Straaten H.W., Klcinjans J.C. and Van Schooten F.J. (2000) Immunoperoxidase delection of 4-aminobiphenyl- and polycyclic aromatic hydrocarbons-DNA adducts in induced sputum of smokers and non-smokers. Mutat Res, 468, 125-135.

28. International Agency for Research on Cancer (1985) Monographs on the evaluation of the carcinogenic risk of chemicals to humans: polynuclear aromatic compounds. Vol. part 4. International Agency for Research on Cancer, Lyon (France).

29. Smith, L.E., Denissenko M.F., Bennelt W.P., Li H., Amin S., Tang M. and Pfeifer G.P. (2000) Targeting of lung cancer mutational hotspots by polycyclic aromatic hydrocarbons. $J$ Natl Cancer Inst, 92, 803-811.

30. US Environmental Protection Agency (1992) Respiratory health effects of passive smoking: lung cancer and other disorders. US Environmental Protection Agency, Office of Health and Environmental Assessment, Office of Research and Development, Washington D.C., EPA/600/6-90/006F.

31. Spitzer, W.O., Lawrence V., Dales R., Hill G., Archer M.C., Clark P., Abenhaim L., Hardy J., Sampalis J., Pinfold S.P. and ct al. (1990) Links between passive smoking and disease: a best-evidence synthesis. A report of the Working Group on Passive Smoking. Clin Invest Med, 13, 17-42.

32. Tredaniel, J., Boffetta P., Saracci R. and Hirsch A. (1994) Exposure to environmental tobacco smoke and risk of lung cancer: the epidemiological evidence. Eur Respir J, 7, 1877-1888. 
33. Leonard, C.T. and Sachs D.P.L. (1999) Environmental tobacco smoke and lung cancer incidence. Curr Opinion Pul Med, 5, 189-193.

34. Nia, A.B., Van Schooten F.J., Schilderman P.A.E.L., De Kok T.M.C.M., Haenen G.R., Van Herwijnen M.H.M., Van Agen E., Pachen D. and Kleinjans J.C. (2001) A multi-biomarker approach to study smoking-induced oxidative DNA damage and repair and antioxidative defense mechanisms. Carcinogenesis. 22, 101-107

35. Loft, S., Vistisen K., Ewertz M., Tjonneland A., Overvad K. and Poulsen H.E. (1992) Oxidative DNA damage estimated by 8-hydroxydeoxyguanosine excretion in humans: influence of smoking, gender and body mass index. Carcinogenesis, 13, 2241-2247.

36. Loft, S., Poulsen H.E., Vistisen K. and Knudsen L.E. (1999) Increased urinary excretion of 8-oxo-2'deoxyguanosine, a biomarker of oxidative DNA damage, in urban bus drivers. Mutat Res, 441, 11-19.

37. Loft, S., Fischer-Nielsen A., Jeding I.B., Vistisen K. and Poulsen H.E. (1993) 8Hydroxydeoxyguanosine as a urinary biomarker of oxidative DNA damage. $J$ Toxicol Environ Health, 40, 391-404.

38. Yin, B., Whyatt R.M., Perera F.P., Randall M.C., Cooper T.B. and Santella R.M. (1995) Determination of 8-hydroxydeoxyguanosine by an immunoaffinity chromatography-monoclonal antibody-based ELISA. Free Radic Biol Med, 18, 1023-1032.

39. Hardie, L.J., Briggs J.A., Davidson L.A., Allan J.M., King R.F., Williams G.I. and Wild C.P. (2000) The effect of hOGGl and glutathione peroxidase 1 genotypes and $3 \mathrm{p}$ chromosomal loss on 8hydroxydeoxyguanosine levels in lung cancer. Carcinogenesis, 21, 167-172.

40. Shinmura, K., Kohno T., Kasai H., Koda K., Sugimura H. and Yokota J. (1998) Infrequent mutations of the hOGGl gene, that is involved in the excision of 8-hydroxyguanine in damaged DNA, in human gastric cancer. Jpn J Cancer Res, 89, 825-828.

41. Sugimura, H., Kohno T., Wakai K., Nagura K., Genka K., Igarashi H., Morris B.J., Baba S., Ohno Y., Gao C., Li Z., Wang J., Takezaki T., Tajima K., Varga T., Sawaguchi T., Lum J.K., Martinson J.J., Tsugane S., Iwamasa T., Shinmura K. and Yokota J. (1999) hOGGI Ser326Cys polymorphism and lung cancer susceptibility. Cancer Epidemiol Biomarkers Prev, 8, 669-674.

42. Meijer, G.A., Westerterp K.R., Saris W.H. and ten Hoor F. (1992) Sleeping metabolic rate in relation to body composition and the menstrual cycle. Am J Clin Nutr, 55, 637-640.

43. Nia, A.B., Van Straaten H.W., Godschalk R.W., Van Zandwijk N., Balm A.J., Kleinjans J.C. and Van Schooten F.J. (2000) Immunoperoxidase detection of polycyclic aromatic hydrocarbon-DNA adducts in mouth floor and buccal mucosa cells of smokers and nonsmokers. Environ Mol Mutagen, 36, 127-133.

44. Hicks, W.L., Jr., Loree T.R., Garcia R.I., Maamoun S., Marshall D., Orner J.B., Bakamjian V.Y. and Shedd D.P. (1997) Squamous cell carcinoma of the floor of mouth: a 20-year review. Head Neck, 19 , $400-405$.

45. Negri, E., La Vecchia C., Levi F., Franceschi S., Serra-Majem L. and Boyle P. (1996) Comparative descriptive epidemiology of oral and oesophageal cancers in Europe. Eur J Cancer Prev, 5, 267-279.

46. Swango, P.A. (1996) Cancers of the oral cavity and pharynx in the United States: an epidemiologic overview. J Public Health Dent, 56, 309-318.

47. De Flora, S., Balansky R., Bennicelli C., Camoirano A., D'Agostini F., Izzotti A. and Cesarone C. (1995) Mechanisms of anticarcinogenesis: the example of $N$-acetylcysteine. In Ioannides, C. and Lewis, D.F.V. (cds), Drugs, Diet and Disease. Vol. 1. Mechanistic approaches to cancer. Horwood Ellis, Hemel Hempstead, pp. 151-203. 
48. De Flora, S. and Ramel C. (1988) Mechanisms of inhibitors of mutagenesis and carcinogenesis. Classification and overview. Mutat Res, 202, 285-306.

49. De Flora, S., Bagnasco M. and Zanacchi P. (1992) Classification and mechanism of action of chemopreventive compounds. In De Palo, G., Sporn, M. and Veronesi, U. (eds), Progress and Perspectives in Chemoprevention of Cancer. Raven Press, New York, pp. 1-11.

50. De Flora, S., Izzotti A. and Bennicelli C. (1993) Mechanisms of antimutagenesis and anticarcinogenesis. Role in primary prevention. In Bronzetti, G., Hayatsu, H., De Flora, S., Waters, M.D. and Shankel, D.M. (eds), Antimutagenesis and Anticarcinogenesis Mechanisms III. Plenum Press, New York, pp. 1-16.

51. De Flora, S., Cesarone C.F., Balansky R.M., Albini A., D'Agostini F., Bennicelli C., Bagnasco M., Camoirano A., Scatolini L., Rovida A. and et al. (1995) Chemopreventive properties and mechanisms of $N$-Acetylcysteine. The experimental background. J Cell Biochem Suppl, 22, 33-41.

52. De Flora, S., Astengo M., Serra D. and Bennicelli C. (1986) Inhibition of urethane-induced lung tumors in micc by dictary $N$-acetylcysteine. Cancer Lett, 32, 235-241.

53. Rogers. D.F. and Jeffery P.K. (1986) Inhibition by oral $N$-acetylcystcine of cigarette smoke-induced "bronchitis" in the rat. Exp Lung Res, 10, 267-283.

54. Wilpart, M., Speder A. and Roberfroid M. (1986) Anti-initiation activity of $N$-acctylcysteine in experimental colonic carcinogenesis. Cancer Lett, 31, 319-324.

55. De Flora, S., D'Agostini F., Izzotti A. and Balansky R. (1991) Prevention by $N$-acetylcysteine of benzo[a]pyrene clastogenicity and DNA adducts in rats. Mutat Res, 250, 87-93.

56. Pereira, M.A. and Khoury M.D. (1991) Prevention by chemopreventive agents of azoxymethane-induced foci of aberrant crypts in rat colon. Cancer Lett, 61, 27-33.

57. Bagnasco, M., Bennicelli C., Camoirano A., Balansky R.M. and De Flora S. (1992) Metabolic aiterations produced by cigarette smoke in rat lung and liver, and their modulation by oral $\mathrm{N}$ acetylcystcinc. Mutagenesis, 7, 295-301.

58. Balansky, R.B., D'Agostini F., Zanacchi P. and De Flora S. (1992) Protection by N-acetylcysteine of the histopathological and cylogenetical damage produced by exposure of rats to cigarette smoke. Cancer Lett, 64, 123-131.

59. Izzotti, A., Balansky R.M., Coscia N., Scatolini L., D'Agostini F. and De Flora S. (1992) Chemoprevention of smokc-related DNA adduct formation in rat lung and heart. Carcinogenesis, 13 , 2187-2190.

60. Izzotti, A., Balansky R., Scatolini L., Rovida A. and De Flora S. (1995) Inhibition by $\mathrm{N}$-acetylcysteine of carcinogen-DNA adducts in the tracheal epithelium of rats exposed to cigarettc smoke. Carcinogenesis, 16, 669-672.

61. Balansky, R., Izzotti A., Scatolini L., D'Agostini F. and De Flora S. (1996) Induction by carcinogens and chemoprevention by $\mathrm{N}$-acetylcysteine of adducts to mitochondrial DNA in rat organs. Cancer Res, 56, 1642-1647.

62. Arif, J.M., Cairola C.G., Glauert H.P., Kelloff G.J., Lubet R.A. and Gupta R.C. (1997) Effects of dietary supplementation of $\mathrm{N}$-acetylcystcine on cigarette smoke-related DNA adducts in rat tissues. Int $J$ Oncol, 11, 1227-1233. 


\section{SAMENVATTING}

In tabaksrook zijn meer dan 4000 chemische stoffen aanwezig waaronder 50 stoffen die mutageen en carcinogeen zijn gebleken in experimentele modellen en/of in de mens. Onder deze mutagene verbindingen bevinden zich de polycyclische aromatische koolwaterstoffen (PAK), aromatische amines en reactieve zuurstofverbindingen (ROS). Na blootstelling aan deze verbindingen zijn de volgende opeenvolgende stappen te onderscheiden; opname door het lichaam, biotransformatie in reactieve metabolieten, vorming van DNA interactie producten (DNA adducten), genetische veranderingen zoals oncogen-activatie en tumor-suppressorgeninactivatie, en uiteindelijk de inductie van kwaadaardige tumoren. In het algemeen kan de tabaksrook gerelateerde carcinogene werking gevolgd worden door binnen deze keten van gebeurtenissen te monitoren, beginnend bij blootstelling aan tabaksrook tot de uiteindelijke ontwikkeling van tumoren. Deze benadering, ook wel biomonitoring genoemd, maakt gebruik van markers van blootstelling, markers van inwendige dosis, markers van moleculaire dosis, markers van preklinische effecten, markers van ziekte en markers van gevoeligheid. Markers die de gebeurtenissen aan het einde van deze keten weerspiegelen geven niet alleen een indruk van blootstelling maar tevens een indicatie van het risico. Idealiter zou biomonitoring plaats dienen te vinden in die organen waarin de tumor-vorming plaatsvindt (doelwitorganen). Echter, het is niet altijd mogelijk doelwitorganen zoals de long, te bestuderen vanwege de onmogelijkheid op routinematige basis weefsel hiervan te verkrijgen. Daarom wordt vaak gebruik gemaakt van surrogaatweefsels zoals witte bloedcellen. Een nadeel van het gebruik van surrogaatweefsel is, dat de gebeurtenissen hierin niet altijd representatief zijn voor hetgeen zich in het doelwitorgaan afspeelt. In onderhavige proefschrift is tabaksrook geïnduceerde carcinogeniteit bestudeerd in menselijk materiaal afkomstig van doelwit- en surrogaatweefsel door kwantificering van markers van moleculaire dosis zoals PAK-, aromatische amine- en ROS geïnduceerde DNA adducten.

Hoofdstuk 2 beschrijft een toepassing waarbij gebruik wordt gemaakt van geïnduceerd sputum, waarin zich cellen bevinden afkomstig van de lagere luchtwegen. Hoofdstuk 3 is een validatie studie waarbij DNA adduct metingen in geïnduceerd sputum vergeleken worden met die in perifere bloed lymfocyten. Hoofdstuk 4 beschrijft een studie waarin door immunohistochemische bepalingen in geïnduceerd sputum de relatieve bijdrage van PAKDNA adducten en aromatische amine-DNA adducten met elkaar vergeleken wordt. Hoofdstuk 5 beschrijft een onderzoek waarin de relatie wordt bestudeerd van tabaksrook gerelateerde DNA adducten in geïnduceerd sputum en perifere bloed lymfocyten worden bestudeerd in relatie tot passieve blootstelling aan tabaksrook. In hoofdstuk 6 worden markers van oxidatieve DNA schade alsmede anti-oxidatieve verdedigingsmechanismen in rokers bestudeerd. In hoofdstuk 7 worden niveaus van DNA adducten vergeleken in verschillende locaties van de mondholte met verschillende gevoeligheidsprofielen voor kanker. Hoofdstuk 8 beschrijft een chemopreventieve studie met $N$-acetyl-L-cysteïne (NAC) in rokende vrijwilligers. In hoofdstuk 9 wordt tenslotte een overzicht gegeven van de uiteindelijke resultaten, samenvatting en aanbevelingen voor toekomstig onderzoek.

Geconcluderend kan worden dat biomonitoring van PAK- en aromatische amine-DNA adducten in doelwit- en relevant surrogaatweefsel, in het bijzonder geïnduceerd sputum, een waardevolle benadering is om tabaks-gerelateerde carcinogenese te bestuderen. Echter, de 
relevantie van ROS- geïnduceerde DNA adducten en andere oxidatieve-stress markers in dit soort studies, is nog niet zeker. Om de mechanistische rol van chemische kankerverwekkende stoffen in tabaks-gerelateerde carcinogenese op te helderen, zal meer grootschalig onderzoek uitgevoerd moeten worden. Hierbij dienen de rol van DNA adducten in doelwit- en surrogaatweefsel bestudeerd te worden in combinatie met genotypering en/of fenotypering van biotransformatie en DNA repair enzymen. 